\title{
POSSIBILITIES FOR A POST-COLONIAL ARCHITECTURE IN RESIDENTIAL NEW ZEALAND
}

BY

\section{JOSHUA BLANDFORD}

\author{
A thesis \\ Submitted to the Victoria University of Wellington \\ In fulfilment of the requirements for the degree of \\ Masters of Architecture (Professional)
}

Victoria University of Wellington

(2013) 


\begin{abstract}
$\underline{\text { Abstract }}$
The ability of architecture to mediate cultural identities, and prescribe spatial practices, empowers it as it provides an avenue through which it can persuade, legitimate, or dominate physical space; not only in terms of how it is conceived of, but also how the social interactions the occur within space are ordered. In other words architecture allows ideology, knowledge and therefore power to mediate space, both physically and culturally. This realisation must result in a heightened questioning and critique of how historic and contemporary architecture functions as a socio-spatial object, and challenge the treatment of architecture as a field autonomous from social and political influence. This is particularly important in countries such as New Zealand, that find their roots in a colonial past, where space, land, and building are at the forefront of cultural appropriation and domination.
\end{abstract}

This thesis investigates the possibilities of producing post-colonial residential forms of architecture through challenging the inherently colonial practices and mechanisms of representation of modern architectural discourse. Situating the investigation within the context of the New Zealand State House, the thesis first seeks to investigate how the State House, and the mechanisms used to represent it, mediated colonial and imperial narratives of space, culture, and society. It also investigates the presence of Bhabha's performative and Lefebvre's lived space within the State House developments of Eastern Porirua in contemporary society, to gauge the ways in which inhabitants themselves have challenged the colonial narratives meditated by the state house, and to establish a list of criteria that is used to guide the development of the designs later in the thesis.

Second, it seeks to investigate the possibilities for creating a new, what will be termed post-colonial, architectural position through challenging the colonial narratives mediated by the State House and the mechanisms used to represent it with previously suppressed social and cultural narratives. The work follows post-structural and post-colonial theories developed by Foucault, Bourdieu, Lefebvre, Bhabha, and Said, and extends their literature based concepts into design experimentation. The thesis presents two residential outcomes, both sited within the State House dominated suburbs of Eastern Porirua. Each outcome is generated through its own design experiment. The first design experiment and outcome challenges colonial mechanisms of architectural representation with the architecture of the wharenui, and, whilst located in the general area of the State House suburbs of Eastern Porirua, is not specifically sited due to the process of the experiment causing the design to be site-less. The second design experiment and outcome challenges the colonial position of the New Zealand State House through reading a State House site within Eastern Porirua through Shirres' interpretation of the Māori spatial concepts of tapu and noa.

The outcomes, despite being produced within established methods of architectural design, make three important positional shifts towards a post-colonial architecture. The first of these is that it produced a critique through alternate cultural architectural and spatial narratives, despite these narratives becoming reframed by the colonial narratives they challenge. The second is that they enacted historical and traditional narratives as forms of critique to architectural practice, removing the disjunction between architectural practice and historical critique. The third is that it incorporated evidence of the spatial practices and perceptions of lived space and the performative into the design, minimising the disjunction between the abstract nature of architectural practice and the fluid activity of everyday life. 


\section{Table of Contents}

Acknowledgements.

List of Illustrations.

Introduction.

Chapter One: Literature Review: Space, Architecture, and Society.

Chapter Two: An Introduction and Analysis of the

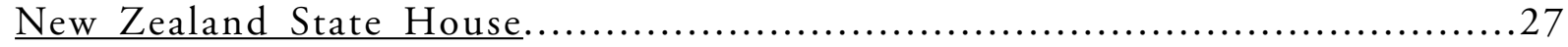

Section One: An Introduction to the New Zealand State House..........................28

Section Two: An Analysis of the New Zealand State House............................38

Chapter Three: Extended Site Analysis: An Empirical Investigation into Lived Space and the Performative in Eastern Porirua.

Chapter Four: Concept: Finding a Post-Colonial Architecture

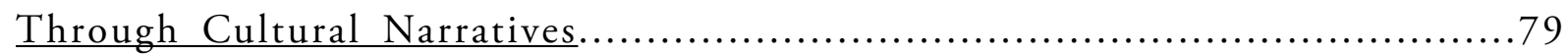

Section One: Introduction to Maori Narratives and Concepts...........................80

Section Two: Conceptual Design Experimentation..................................................86

Chapter Five: Description and Analysis of Final Design Outcomes...............125

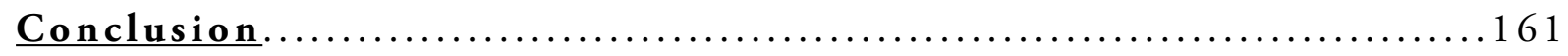

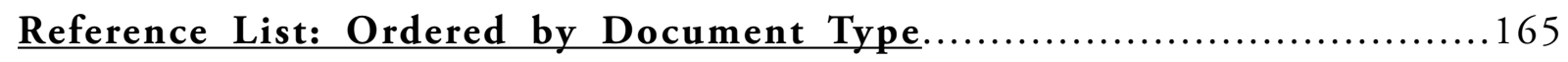

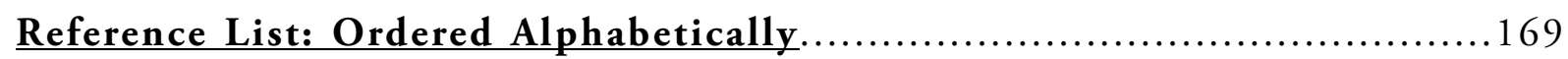




\section{Acknowledgements}

This thesis would not have been able to arise without the support, kindness, and generosity of many people whose contributions I would like to acknowledge here. Firstly I would like to thank Christine McCarthy, whose constant guidance and critique pushed this research into increasingly rich levels of experimentation and resolution. Secondly I would like to thank my peers, and those who attended and contributed to reviews of my work throughout the year; Kirsten Thompson, Simon Twose, Derek Kawiti, Tyson Schmidt, Gary Whiting, Nat Perkins, Peter Parkes, Gordon Holden, Philippe Campays, and Bernice Williams. I also give sincere thanks to Rosie Gallen from Wellington City Council for providing me with the resources regarding the People and Places outcomes of Housing New Zealand Corporation's Community Renewal Programme, Fiona Drummond from Housing New Zealand Corporation for providing me with house plans used in Eastern Porirua, and the staff of Archives New Zealand's Wellington Office, whose help and patience in finding resources was invaluable. Additionally I extend thanks to the Head of School of Māori Studies at Victoria University, Peter Adds, for his sharing of knowledge surrounding Māori culture, space and architecture. Lastly I would like to extend the warmest of thanks to my family and partner Rosemary, whose support and belief throughout this process has been constant and unwavering. 


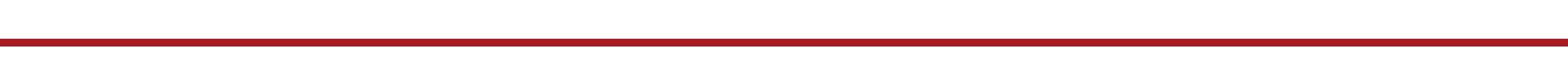




\section{List of Illustrations}

Figure 1.1 Thesis Structure Diagram, author's own image

Figure 2.1 Gamma Analysis Overlays of Detached State House Plans, plans collected from: Housing Corporation of New Zealand, Head Office [agency code AALF], "Photographs of State Housing Plans”, Container code: C 398 664, Ref. No. AALF W1559 6114 Box 1, undated, accessed on 30/4/2012

Figure 2.2 Gamma Analysis Overlays of Department of Māori Affairs House Plans, plans collected from: Department of Māori Affairs, "Nga Whare Ataahua Mo Te Iwi Māori”, undated [ca: 1950-1960], also Te Ao Hou, "Homes for the Māori People", Te Ao Hou, No.10 (April, 1955), 30-31

Figure 2.3 Plan and Gamma Analysis of Bungalow "Modern Home No.147”, plan collected from: Sears, "Modern Home No.147", Modern Homes: Mail order catalogue, 1909-1917, 54, accessed at About.com, "Bungalow Floor Plans”, http://architecture.about.com/library/nbungalowplan-s-147.htm, accessed on 2/5/2012

Figure 2.4 Plan and Gamma Analysis of Bungalow "Modern Home No.144", plan collected from: Sears, "Modern Home No.144", Modern Homes: Mail order catalogue, 1909-1913, 26, accessed at About.com, "Bungalow Floor Plans”, http://architecture.about.com/library/bl-bungalowplan-s-144.htm, accessed on 2/5/2012

Figure 2.5 Plan and Gamma Analysis of Samuel Hurst Seager's "Cranmer Club”, plan collected from: Shaw, Peter, $A$ History of New Zealand Architecture. Auckland: Hodder Moa Beckett Publishers Ltd, 2003, 85

Figure 2.6 Plan and Gamma Analysis of "Design No.44” from James Christie’s Catalogue of New Zealand Homes [ca. 1910], plan collected from: Shaw, Peter, A History of New Zealand Architecture. Auckland: Hodder Moa Beckett Publishers Ltd, 2003, 45

Figure 2.7 Gamma Analysis Overlays of State House Multi-units, plans collected from: Housing Corporation of New Zealand, Head Office [agency code AALF], "Photographs of State Housing Plans”, Container code: C 398 664, Ref. No. AALF W15596114 Box 1, undated, accessed on 30/4/2012

Figure 2.8 "Typical Layout of a Housing Scheme of about 600 Units", Wilson, Gordon, from: Firth, Cedric, State Housing in New Zealand, (Wellington: Ministry of Works, 1949), 82

Figure 2.9 "Typical Site Plan", Wilson, Gordon, from: Firth, Cedric, State Housing in New Zealand, (Wellington: Ministry of Works, 1949), 81

Figure 2.10 "Site Plan of Road Intersection”, Wilson, Gordon, from: Cedric, State Housing in New Zealand, (Wellington: Ministry of Works, 1949), 80

Figure 2.11 State House Front Elevation Overlays, elevations collected from: Housing Corporation of New Zealand, Head Office [agency code AALF], "Photographs of State Housing Plans", Container code: C 398 664, Ref. No. AALF W1559 6114 Box 1, undated, viewed on 30/4/2012

Figure 2.12 State House Plan used within the State House Development of Block 7b, Cannons Creek, Porirua [ca: 1960-65], plan obtained from Housing New Zealand Corporation, plan No. "W6/307/S1"

Figure 2.13 State House Plan used within the State House Development of Block 7b, Cannons Creek, Porirua [ca: 1960-65], plan obtained from Housing New Zealand Corporation, plan No. "D6/1545/S1"

Figure 2.14 State House plan No. "W6/156/S1" used within a Development of Two Homes using New Experimental Construction Methods in Porirua [ca: 1962], plan collected from Housing Corporation of New Zealand, Wellington District Office [AAQV], "Photographic Records, Maps, Plans of Porirua and Whitby Developments: [b/w photographs - aerials and of house and buildings in and around Porirua]", Container code: C554182, Archives Ref. No. AAQV W3361 Box 1, undated, accessed on 20/4/2012

Figure 2.15 State House plan No. "W6/276/S1" used within a Development of Two Homes using New Experimental Construction Methods in Porirua [ca: 1962], plan collected from Housing Corporation of New Zealand, Wellington District Office [AAQV], "Photographic Records, Maps, Plans of Porirua and Whitby Developments: [b/w photographs - aerials and of house and buildings in and around Porirua]", Container code: C554182, Archives Ref. No. AAQV W3361 Box 1, undated, accessed on 20/4/2012 
Figure 2.16 State House Multi-unit Plan used within the State House Development of Block 7b, Cannons Creek, Porirua [ca: 1960-65], plan obtained from Housing New Zealand Corporation, plan No. "7E/242/S1"

Figure 2.17 State House Multi-unit Plan used within the State House Development of Block 7b, Cannons Creek, Porirua [ca: 1960-65], plan obtained from Housing New Zealand Corporation, plan No. "11/102/S1"

Figure 2.18 "State Housing in Porirua East", New Zealand Free Lance: Photographic prints and negatives. Ref: 1/2051884-F. Alexander Turnbull Library, Wellington, New Zealand. http://natlib.govt.nz/records/22865972

Figure 2.19 "Porirua East Development" [ca: July 1960], Housing Corporation of New Zealand, Wellington District Office [AAQV], "Photographic Records, Maps, Plans of Porirua and Whitby Developments: [b/w photographs aerials and of house and buildings in and around Porirua]", Container code: C554182, Archives Ref. No. AAQV W3361 Box 1, undated, accessed on 20/4/2012

Figure 2.20 Untitled Aerial Image of Porirua [ca: 1965], Housing Corporation of New Zealand, Wellington District Office [AAQV], "Photographic Records, Maps, Plans of Porirua and Whitby Developments: [b/w photographs aerials and of house and buildings in and around Porirua]", Container code: C554182, Archives Ref. No. AAQV W3361 Box 1, undated, accessed on 20/4/2012

Figure 2.21 "Suburban Street, with Power Poles, Porirua, Wellington", Winder, Duncan, [between ca: 1962 and 1965]: Architectural photographs. Ref: DW-1577-F. Alexander Turnbull Library, Wellington, New Zealand. http:// natlib.govt.nz/records/23215658

Figure 2.22 Untitled Photograph of State Houses within Porirua East, 10/5/2012, author's own photograph

Figure 2.23 Overlays of Aerial Photographic Images of Porirua 1, images collected from Housing Corporation of New Zealand, Wellington District Office [AAQV], "Photographic Records, Maps, Plans of Porirua and Whitby Developments: [b/w photographs - aerials and of house and buildings in and around Porirua]", Container code: C554182, Archives Ref. No. AAQV W3361 Box 1, undated, accessed on 20/3/2012

Figure 2.24 Overlays of Aerial Photographic Images of Porirua 2, images collected from Housing Corporation of New Zealand, Wellington District Office [AAQV], "Photographic Records, Maps, Plans of Porirua and Whitby Developments: [b/w photographs - aerials and of house and buildings in and around Porirua]", Container code: C554182, Archives Ref. No. AAQV W3361 Box 1, undated, accessed on 20/3/2012

Figure 2.25 "Wellington - Porirua Township Area: Plan No.HDW31756", Ministry of Works, Housing Division [AAPO], "Wellington - Johnsonville; Porirua; Titahi Bay [3 maps], Container code: C425012, Archives Ref. No. AAPO W1100 6489 Box 11, undated, accessed on 20/3/2012

Figure 2.26 "Proposed Additions to City of Porirua", Housing Corporation of New Zealand, Wellington District Office $[A A Q V]$, "Photographic Records, Maps, Plans of Porirua and Whitby Developments: [b/w photographs aerials and of house and buildings in and around Porirua]", Container code: C554182, Archives Ref. No. AAQV W3361 Box 1, undated, accessed on 20/3/2012

Figure 2.27 "Porirua Development", Housing Corporation of New Zealand, Head Office [AALF], "Porirua Development", Container code: C398662, Archives Ref. No. AALF W15596112 Box 3, Rec. No. 20/15, undated, accessed on $21 / 3 / 2012$

Figure 2.28 "Porirua Basin Development Scheme", Housing Corporation of New Zealand, Head Office [AALF], "Proposed Development, Porirua", Container code: C398662, Archives Ref. No. AALF W15596112 Box 3, Rec. No. 20/14, undated, accessed on 20/3/2012

Figure 2.29 "Plan Showing the Probable General Development of the Areas About Porirua and Pahautanui [1]", Greater Wellington Regional Council [ADIF], "Plan Showing the Probable General Development of the Areas about Porirua and Pauatahanui (April 1948, R.P.A. [Regional Planning Authority] Print, Tracing xC11/2, 20 chains)”, Container code: C607874, Archives Ref. No. ADIF W3993 Box 7, Rec. No. xC11/2, 1948, accessed on 6/7/2012

Figure 2.30 "Plan Showing the Probable General Development of the Areas About Porirua and Pahautanui [2]", Greater Wellington Regional Council [ADIF], "Plan Showing the Probable General Development of the Areas about Porirua and Pauatahanui (April 1948, R.P.A. [Regional Planning Authority] Print, Tracing xC11/2, 20 chains)", Container code: C607874, Archives Ref. No. ADIF W3993 Box 7, Rec. No. xC11/2, 1948, accessed on 6/7/2012 
Figure 2.31 "Porirua No.3/2/3D", Greater Wellington Regional Council [ADIF], "Planning Data Map - Porirua Borough as at November 1963”, Container code: C607876, Archives Ref. No. ADIFW3993 Box 9, Rec. No. x3/2/3/C, 1963, accessed on 6/7/2012

Figure 2.32 Porirua Landscape Overlay Image 1, photographs collected from: Housing Corporation of New Zealand, Wellington District Office [AAQV], "Photographic Records, Maps, Plans of Porirua and Whitby Developments: [b/w photographs - aerials and of house and buildings in and around Porirua]", Container code: C554182, Archives Ref. No. AAQV W3361 Box 1, undated, accessed on 20/3/2012

Figure 2.33 Porirua Landscape Overlay Image 2, photographs collected from: Housing Corporation of New Zealand, Wellington District Office [AAQV], "Photographic Records, Maps, Plans of Porirua and Whitby Developments: [b/w photographs - aerials and of house and buildings in and around Porirua]", Container code: C554182, Archives Ref. No. AAQV W3361 Box 1, undated, accessed on 20/3/2012

Figure 2.34 Porirua Landscape Overlay Image 3, photographs collected from: Housing Corporation of New Zealand, Wellington District Office [AAQV], "Photographic Records, Maps, Plans of Porirua and Whitby Developments: [b/w photographs - aerials and of house and buildings in and around Porirua]", Container code: C554182, Archives Ref. No. AAQV W3361 Box 1, undated, accessed on 20/3/2012

Figure 2.35 Front and Rear of Landscape Images from the Development of Porirua East, photographs collected from: Housing Corporation of New Zealand, Wellington District Office [AAQV], "Photographic Records, Maps, Plans of Porirua and Whitby Developments: [b/w photographs - aerials and of house and buildings in and around Porirua]", Container code: C554182, Archives Ref. No. AAQV W3361 Box 1, undated, accessed on 20/3/2012

Figure 2.36 Photographs of State House Plans 6/882/S1, 6/1282/S1, 6/1411/S1, 6/1326/S1, 6/1435/S1, 6/1412/S1, 6/706/S1, 6/635/S1, plans collected from Housing Corporation of New Zealand, Head Office [agency code AALF], "Photographs of State Housing Plans", Container code: C 398 664, Ref. No. AALF W1559 6114 Box 1, undated, accessed on $30 / 4 / 2012$

Figure 2.37 Porirua Landscape Overlay Image 4, photographs collected from: Housing Corporation of New Zealand, Wellington District Office [AAQV], "Photographic Records, Maps, Plans of Porirua and Whitby Developments: [b/w photographs - aerials and of house and buildings in and around Porirua]", Container code: C554182, Archives Ref. No. AAQV W3361 Box 1, undated, accessed on 20/3/2012

Figure 2.38 Porirua Landscape Overlay Image 5, photographs collected from: Housing Corporation of New Zealand, Wellington District Office [AAQV], "Photographic Records, Maps, Plans of Porirua and Whitby Developments: [b/w photographs - aerials and of house and buildings in and around Porirua]", Container code: C554182, Archives Ref. No. AAQV W3361 Box 1, undated, accessed on 20/3/2012

Figure 2.39 Drawing Exploring the Transformation of the Land to Landscape in Porirua East, photographs collected from: Housing Corporation of New Zealand, Wellington District Office [AAQV], "Photographic Records, Maps, Plans of Porirua and Whitby Developments: [b/w photographs - aerials and of house and buildings in and around Porirua]", Container code: C554182, Archives Ref. No. AAQV W3361 Box 1, undated, accessed on 20/3/2012

Figure 2.40 State House Nuclear Family Overlay, photographs collected from: Mark Derby. "Suburbs - Suburban life since the 1970s", Te Ara - the Encyclopaedia of New Zealand, updated 16-Nov-12, URL: http://www.TeAra. govt.nz/en/photograph/25073/nuclear-family, also Wilson Gordon, "Family Centre", Firth, Cedric, State Housing in New Zealand, (Wellington: Ministry of Works, 1949), n.p.n., and Housing Corporation of New Zealand, Wellington District Office [AAQV], "Photographic Records, Maps, Plans of Porirua and Whitby Developments: [b/w photographs - aerials and of house and buildings in and around Porirua]", Container code: C554182, Archives Ref. No. AAQV W3361 Box 1, undated, accessed on 20/3/2012, Steer, Jordan, “1950s Nuclear Family”, Nuclear Family 1950s, undated, http://nuclear-famliy-jsteer.blogspot.co.nz/2013/01/images-of-1950s-nuclear-family.html, and JustForSneaks07, “Typical 1950's Suburban Nuclear Family”, Nobody Reads Anymore: Volume 2, 16/4/2011, http:// justforsneaks.wordpress.com/2011/04/16/typical-1950s-suburban-nuclear-family/

Figure 2.41 State House Female Gender Role Overlay, photographs collected from: Wilson Gordon, "Average Family", "Kitchen”, "Modern Kitchen”, Firth, Cedric, State Housing in New Zealand, (Wellington: Ministry of Works, 1949), n.p.n., "State House Kitchen”, Schrader, Ben, We Call it Home: A History of State Housing in New Zealand, 94 
Figure 2.42 Conceptual Drawing of State House Colonial Action 1, original images collected from: Firth, Cedric, State Housing in New Zealand, (Wellington: Ministry of Works, 1949), also Best, Elsdon, The Pa Mãori: An account of the fortified villages of the Mãori in pre-European and modern times; Illustrating methods of defence by means of ramparts, fosses, scarps and stockades, (Wellington: A.R. Shearer Government Printer, 1975)

Figure 2.43 Conceptual Drawing of State House Colonial Action 2, original images collected from: Firth, Cedric, State Housing in New Zealand, (Wellington: Ministry of Works, 1949), also Housing Corporation of New Zealand, Wellington District Office [AAQV], "Photographic Records, Maps, Plans of Porirua and Whitby Developments: [b/w photographs - aerials and of house and buildings in and around Porirua]", Container code: C554182, Archives Ref. No. AAQV W3361 Box 1, undated, accessed on 20/3/2012, and New Zealand Labour Party. New Zealand Labour Party: Labour guarantees homes for all. [1957?]. Ref: Eph-A-HOUSING-1957-01. Alexander Turnbull Library, Wellington, New Zealand. http://natlib.govt.nz/records/22870586 , and State Advances Corporation of New Zealand. State Advances Corporation of New Zealand :The advantages of home ownership. [Front and back cover. ca 1951].. Ref: Eph-A-HOUSING-1951-01-recto. Alexander Turnbull Library, Wellington, New Zealand. http://natlib. govt.nz/records/23173092

Figure 2.44 Conceptual Drawing of State House Imperial Action 1, original images collected from Housing Corporation of New Zealand, Wellington District Office [AAQV], "Photographic Records, Maps, Plans of Porirua and Whitby Developments: [b/w photographs - aerials and of house and buildings in and around Porirua]", Container code: C554182, Archives Ref. No. AAQV W3361 Box 1, undated, accessed on 20/3/2012, also New Zealand Labour Party. New Zealand Labour Party :Labour guarantees homes for all. [1957?].. Ref: Eph-A-HOUSING-1957-01. Alexander Turnbull Library, Wellington, New Zealand. http://natlib.govt.nz/ records/22870586, and State Advances Corporation of New Zealand. State Advances Corporation of New Zealand :The advantages of home ownership. [Front and back cover. ca 1951].. Ref: Eph-A-HOUSING-1951-01-recto. Alexander Turnbull Library, Wellington, New Zealand. http://natlib.govt.nz/records/23173092, and Mark Derby. 'Suburbs - Life in the suburbs', Te Ara - the Encyclopaedia of New Zealand, updated 15-Nov-12, URL: http:// www.TeAra.govt.nz/en/photograph/25065/men-in-the-suburbs-1950s , and Skinner, W A G, b 1868?. [New Zealand. Department of Tourist and Health Resorts] :Haere mai (Welcome) to New Zealand. By authority W A G Skinner, Government Printer, Wellington. [1920s].. Ref: Eph-E-TOURISM-1920s-01. Alexander Turnbull Library, Wellington, New Zealand. http://natlib.govt.nz/records/22489836, and Laugesen, Carl Thorwald, 1900-1987. [Laugesen, Carl Thorwald?] 1900-1987 :Visit New Zealand, wonderland of the Pacific / C.L. Full information from The High Commissioner for New Zealand, 415 The Strand, London W C 2 ... C.S.W. Ltd [1930s].. Ref: Eph-E-TOURISM-1930s-08. Alexander Turnbull Library, Wellington, New Zealand.http://natlib. govt.nz/records/23062018, and Mitchell, Leonard Cornwall, 1901-1971. Mitchell, Leonard Cornwall, 1901-1971 :New Zealand for your next holiday. Issued by the New Zealand Government Publicity Office. Wholly printed in New Zealand by Coulls Somerville Wilkie Limited, Dunedin, Christchurch, Wellington, Auckland [ca $1925-$ 1929]. Ref: Eph-E-TOURISM-1920s-02. Alexander Turnbull Library, Wellington, New Zealand. http://natlib. govt.nz/records/23188666, and Westra, Ana, "Washday at the Pa [various images", in Brookes, Barbara, "Nostalgia for 'Innocent homely Pleasures': The 1964 New Zealand Controversy over Washday at the Pa”, At Home in New Zealand: Houses, History, People, ed. Brookes, Barbara, (Wellington: Bridget Williams Books, 2000), 210-225

Figure 2.45 Conceptual Drawing of State House Imperial Action 2, original images collected from: Mitchell, Leonard Cornwall, 1901-1971. Mitchell, Leonard Cornwall, 1901-1971 :New Zealand for your next holiday. Issued by the New Zealand Government Publicity Office. Wholly printed in New Zealand by Coulls Somerville Wilkie Limited, Dunedin, Christchurch, Wellington, Auckland [ca 1925-1929]. Ref: Eph-E-TOURISM1920s-02. Alexander Turnbull Library, Wellington, New Zealand. http://natlib.govt.nz/records/23188666, also Housing Corporation of New Zealand, Wellington District Office [AAQV], "Photographic Records, Maps, Plans of Porirua and Whitby Developments: [b/w photographs - aerials and of house and buildings in and around Porirua]", Container code: C554182, Archives Ref. No. AAQV W3361 Box 1, undated, accessed on 20/3/2012, also New Zealand Labour Party. New Zealand Labour Party :Labour guarantees homes for all. [1957?].. Ref: Eph-A-HOUSING-1957-01. Alexander Turnbull Library, Wellington, New Zealand. http://natlib.govt.nz/ records/22870586, and Māori wooden carved panel, Spa Hotel dining room, Taupo. Best, Elsdon, 1856-1931 :Photographs. Ref: PAColl-4249-05. Alexander Turnbull Library, Wellington, New Zealand. http://natlib.govt. nz/records/22857281, and Artist unknown :Decorated head of the Chief Rauparaha's canoe. [1890]. Sherrin, Richard Arundell Augur, 1832-1893 :Early history of New Zealand, from earliest times to 1840 / R A A Sherrin and J H Wallace. Auckland, Brett, 1890.. Ref: PUBL-0099-028. Alexander Turnbull Library, Wellington, New Zealand. http://natlib.govt.nz/records/23205752 
Figure 2.46 Conceptual Drawing of State House Imperial Action 3, original images collected from: Housing Corporation of New Zealand, Wellington District Office [AAQV], "Photographic Records, Maps, Plans of Porirua and Whitby Developments: [b/w photographs - aerials and of house and buildings in and around Porirua]", Container code: C554182, Archives Ref. No. AAQV W3361 Box 1, undated, accessed on 20/3/2012, also Best, Elsdon, The Pa Mãori: An account of the fortified villages of the Mãori in pre-European and modern times; Illustrating methods of defence by means of ramparts, fosses, scarps and stockades, (Wellington: A.R. Shearer Government Printer, 1975), Skinner, W A G, b 1868?. [New Zealand. Department of Tourist and Health Resorts] :Haere mai (Welcome) to New Zealand. By authority W A G Skinner, Government Printer, Wellington. [1920s].. Ref: Eph-E-TOURISM1920s-01. Alexander Turnbull Library, Wellington, New Zealand. http://natlib.govt.nz/records/22489836, and Laugesen, Carl Thorwald, 1900-1987. [Laugesen, Carl Thorwald?] 1900-1987 :Visit New Zealand, wonderland of the Pacific / C.L. Full information from The High Commissioner for New Zealand, 415 The Strand, London W C 2 ... C.S.W. Ltd [1930s].. Ref: Eph-E-TOURISM-1930s-08. Alexander Turnbull Library, Wellington, New Zealand. http://natlib.govt.nz/records/23062018, and Mitchell, Leonard Cornwall, 1901-1971. Mitchell, Leonard Cornwall, 1901-1971 :New Zealand for your next holiday. Issued by the New Zealand Government Publicity Office. Wholly printed in New Zealand by Coulls Somerville Wilkie Limited, Dunedin, Christchurch, Wellington, Auckland [ca 1925-1929]. Ref: Eph-E-TOURISM-1920s-02. Alexander Turnbull Library, Wellington, New Zealand. http://natlib. govt.nz/records/23188666

Figure 2.47 Conceptual Drawing of State House Imperial Action 4, author's own image.

Figure 2.48 Conceptual Drawing Exploring the Link Between the State House and the Colonial Neo-Georgian Cottage 1, original images from: The Holmes family outside their home in Naenae. Pascoe, John Dobree, 19081972 :Photographic albums, prints and negatives. Ref: 1/4-001168-F. Alexander Turnbull Library, Wellington, New Zealand.http://natlib.govt.nz/records/22700047, also "Cottage at Hampden”, Stacpoole, John, Colonial Architecture in New Zealand, (Wellington: Reed, 1976), 45

Figure 2.49 Conceptual Drawing Exploring the Link Between the State House and the Colonial Neo-Georgian Cottage 2, original images from: The Holmes family outside their home in Naenae. Pascoe, John Dobree, 19081972 :Photographic albums, prints and negatives. Ref: 1/4-001168-F. Alexander Turnbull Library, Wellington, New Zealand.http://natlib.govt.nz/records/22700047, also “Cottage at Hampden”, Stacpoole, John, Colonial Architecture in New Zealand, (Wellington: Reed, 1976), 45

Figure 2.50 Conceptual Drawing Exploring the Link Between the State House and the Colonial Neo-Georgian Cottage 3, original images collected from: Housing Corporation of New Zealand, Head Office [agency code AALF], "Photographs of State Housing Plans", Container code: C 398 664, Ref. No. AALF W1559 6114 Box 1, undated, accessed on 30/4/2012, also Stacpoole, John, Colonial Architecture in New Zealand, (Wellington: Reed, 1976), and Firth, Cedric, State Housing in New Zealand, (Wellington: Ministry of Works, 1949), and Toomath, William, Built in New Zealand: The houses we live in, (Auckland: HarperCollins, 1996)

Figure 2.51 Conceptual Drawing Exploring the Opposition between Colonial and Māori Socio-spatial Life and Architecture 1, original images collected from: St Albans Church, Pauatahanui, Wellington region. Photographer unknown: Views of Hutt County and Porirua. Ref: 1/4-018090-F. Alexander Turnbull Library, Wellington, New Zealand. http://natlib.govt.nz/records/22516716, also Giles, J W fl 1847. Angas, George French, 1822-1886 :Rangihaeata's celebrated house on the island of Mana called "Kaitangata" (eat man) / George French Angas [delt]; J. W. Giles [lith]. Plate 4. 1847.. Angas, George French 1822-1886 :The New Zealanders Illustrated. London, Thomas McLean, 1847.. Ref: PUBL-0014-04. Alexander Turnbull Library, Wellington, New Zealand. http://natlib.govt.nz/ records/22875161

Figure 2.52 Conceptual Drawing Exploring the Opposition between Colonial and Māori Socio-spatial Life and Architecture 2, original images collected from: Mark Derby. 'Suburbs - Suburban life since the 1970s', Te Ara - the Encyclopaedia of New Zealand, updated 16-Nov-12, URL: http://www.TeAra.govt.nz/en/photograph/25073/ nuclear-family, also Māori group outside a meeting house at Waipahihi, includes Rangitahau and Kiriwera. Burton brothers' album 12. Ref: PA1-o-088-13. Alexander Turnbull Library, Wellington, New Zealand. http://natlib.govt.nz/ records/23078919

Figure 3.1 Building Footprints: Cannons Creek, Boffa Miskell Ltd and Graeme McLindoe Architect \& Urban Designer, "Appendix Five: Building Footprint and Street Layout", Porirua Suburban Character Study, (Porirua: Porirua City Council, 2005), 75 
Figure 3.2 Site Coverage Map: Cannons Creek, Boffa Miskell Ltd and Graeme McLindoe Architect \& Urban Designer, "Appendix Four: Slope Analysis and Site Coverage Maps", Porirua Suburban Character Study, (Porirua: Porirua City Council, 2005), 65

Figure 3.3 Slope Analysis: Cannons Creek, Boffa Miskell Ltd and Graeme McLindoe Architect \& Urban Designer, "Appendix Four: Slope Analysis and Site Coverage Maps", Porirua Suburban Character Study, (Porirua: Porirua City Council, 2005), 65

Figure 3.4 Building Footprints: Waitangirua, Boffa Miskell Ltd and Graeme McLindoe Architect \& Urban Designer, "Appendix Five: Building Footprint and Street Layout", Porirua Suburban Character Study, (Porirua: Porirua City Council, 2005), 74

Figure 3.5 Site Coverage Map: Waitangirua, Boffa Miskell Ltd and Graeme McLindoe Architect \& Urban Designer, "Appendix Four: Slope Analysis and Site Coverage Maps", Porirua Suburban Character Study, (Porirua: Porirua City Council, 2005), 64

Figure 3.6 Slope Analysis: Waitangirua, Boffa Miskell Ltd and Graeme McLindoe Architect \& Urban Designer, "Appendix Four: Slope Analysis and Site Coverage Maps", Porirua Suburban Character Study, (Porirua: Porirua City Council, 2005), 64

Figure 3.7 Assorted Images from the People and Places: An Eastside Story Photographic Exhibition currently on display at Keneperu Hospital, Porirua [1], Housing New Zealand Corporation, Porirua City Council and Housing Action Porirua, "Photographic Exhibition", People and Places: An Eastside Story,(Wellington: Housing New Zealand Corporation, 2004)

Figure 3.8 Assorted Images from the People and Places: An Eastside Story Photographic Exhibition currently on display at Keneperu Hospital, Porirua [2], Housing New Zealand Corporation, Porirua City Council and Housing Action Porirua, "Photographic Exhibition", People and Places: An Eastside Story,(Wellington: Housing New Zealand Corporation, 2004)

Figure 3.9 Assorted Images from Aitken, Jonathan, Eastside: A contemporary view of Eastern Porirua [1], (New Zealand: Jonathan Aitken Publishing, 2005)

Figure 3.10 Assorted Images from Aitken, Jonathan, Eastside: A contemporary view of Eastern Porirua [2], (New Zealand: Jonathan Aitken Publishing, 2005)

Figure 3.11 Street Elevation Images from Cannons Creek, Porirua [1], images collected from Google, Google Earth Street View, Miranda Street, Niger Street, Castor Crescent, Esk Place, and Hazard Grove, accessed 15/7/2012

Figure 3.12 Street Elevation Images from Cannons Creek, Porirua [2], images collected from Google, Google Earth Street View, Castor Crescent and Calliope Crescent, accessed 15/7/2012

Figure 4.1 Diagram of the Māori Marae, Austin, Mike, "A Description of the Māori Marae”, (Auckland: University of Auckland, 1980), 233

Figure 4.2 Diagram of the Buildings Within the Māori Marae, Austin, Mike, "A Description of the Māori Marae", (Auckland: University of Auckland, 1980), 235

Figure 4.3 "Wharenui", The University of Waikato, Science Learning Hub, "wharenui", 6/11/2011, http://www. sciencelearn.org.nz/Science-Stories/Measurement/Sci-Media/Images/Wharenui, accessed 20/12/2012

Figure 4.4 "Diagram Showing the Generally Used Names of Meeting House Elements", Bulley, Grant in, Brown, Deidre, Mãori Architecture: From the fale to wharenui and beyond,(Auckland: Raupo, 2009), 52

Figure 4.5 Plan of the Māori Wharenui, Austin, Mike, "A Description of the Māori Marae”, (Auckland: University of Auckland, 1980), 237

Figure 4.6 "A Structural Presentation of Different Permutations of Tapu Thought", Shirres, Michael, "Tapu”, Journal of the Polynesian Society, Vol. 91, No.1, 1982, 42 
Figure 4.7 Wharenui Depiction Image 1: Interior Whakairo and Tukutuku, original images collected from: National Library of New Zealand, Beta Online Search Engine, Individual Search Terms used: Marae, Whare, Wharenui, Pa, Te Ati Awa, Ngati Toa

Figure 4.8 Wharenui Depiction Image 2: Front Entrance Kūwaha, Pare, Whakawae, Whatitoka, and Matapihi, original images collected from National Library of New Zealand, Beta Online Search Engine, Individual Search Terms used: Marae, Whare, Wharenui, Pa, Te Ati Awa, Ngāti Toa

Figure 4.9 Wharenui Depiction Image 3: Front Amo and Raparapa, original images collected from National Library of New Zealand, Beta Online Search Engine, Individual Search Terms used: Marae, Whare, Wharenui, Pa, Te Ati Awa, Ngati Toa

Figure 4.10 Wharenui Depiction Image 4: Interior Perspective, Whakairo, Tukutuku, and Kowhaiwhai, original images collected from National Library of New Zealand, Beta Online Search Engine, Individual Search Terms used: Marae, Whare, Wharenui, Pa, Te Ati Awa, Ngati Toa

Figure 4.11 Wharenui Depiction Image 5: Interior Perspective of Wharenui Interior Space, original images collected from National Library of New Zealand, Beta Online Search Engine, Individual Search Terms used: Marae, Whare, Wharenui, Pa, Te Ati Awa, Ngati Toa

Figure 4.12 Sectional Representation of Depiction Image 1, author's own drawing

Figure 4.13 Sectional Representation of Depiction Image 2, author's own drawing

Figure 4.14 Sectional Representation of Depiction Image 3, author's own drawing

Figure 4.15 Sectional Representation of Depiction Image 4, author's own drawing

Figure 4.16 Sectional Representation of Depiction Image 5, author's own drawing

Figure 4.17 Planar Representation of Depiction Image 1, author's own drawing

Figure 4.18 Planar Representation of Depiction Image 2, author's own drawing

Figure 4.19 Planar Representation of Depiction Image 3, author's own drawing

Figure 4.20 Planar Representation of Depiction Image 4, author's own drawing

Figure 4.21 Planar Representation of Depiction Image 5, author's own drawing

Figure 4.22 Axonometric Representation of Depiction Image 1, author's own drawing

Figure 4.23 Axonometric Representation of Depiction Image 2, author's own drawing

Figure 4.24 Axonometric Representation of Depiction Image 3, author's own drawing

Figure 4.25 Axonometric Representation of Depiction Image 4, author's own drawing

Figure 4.26 Axonometric Representation of Depiction Image 5, author's own drawing

Figure 4.27 Image Group of Depiction Image 1, author's own drawing

Figure 4.28 Image Group of Depiction Image 2, author's own drawing

Figure 4.29 Image Group of Depiction Image 3, author's own drawing

Figure 4.30 Image Group of Depiction Image 4, author's own drawing

Figure 4.31 Image Group of Depiction Image 5, author’s own drawing

Figure 4.32 Plan of Conceptual Outcome Generated from Image Group of Depiction 2, author's own drawing 
Figure 4.33 Section of Conceptual Outcome Generated from Image Group of Depiction 2, author's own drawing

Figure 4.34 Exterior Perspective of Conceptual Outcome Generated from Image Group of Depiction 2, author's own drawing

Figure 4.35 Exterior Perspective of Experiment Two's Site Pre-removal of the State House, Google, Google Street View, Castor Crescent, Cannons Creek, Porirua, Image dated November 2009, accessed 10/5/2012

Figure 4.36 Site Plan of Experiment Two's Site Pre-removal of the State House, house plan obtained from Housing New Zealand Corporation, House No. W6/307/S1

Figure 4.37 Exterior Perspective of Experiment Two's Site Current Condition, author's own image

Figure 4.38 Site Plan of Experiment Two's Site Current Condition, author's own drawing

Figure 4.39 Plan Card of Experiment Two's Site Original State House, house plan obtained from Housing New Zealand Corporation, House No. W6/307/S1

Figure 4.40 Enlarged Plan of Experiment Two's Site Original State House, house plan obtained from Housing New Zealand Corporation, House No. W6/307/S1

Figure 4.41 Drawing Analysing the Relationship between the Intrinsic Tapu of People Within and between the Living and Bedroom Areas of the Original House, author's own drawing

Figure 4.42 Drawing Analysing the Relationship between the Intrinsic Tapu of People and of Cultivated Foods Established by the Entrance, Consumption, and Removal of Food Within the Site, author's own drawing

Figure 4.43 Drawing Analysing the Relationship between the Intrinsic Tapu of the Occupants and Visitors to the Site Established by the Site and House Entrances and the Communal Passages and Living Areas Within the Site, author's own drawing

Figure 4.44 Drawing Analysing the Relationship between the Intrinsic Tapu of People as Occupiers of the Site and the Land Established Through the Physical Architecture, author's own drawing

Figure 4.45 Drawing Analysing the Relationship between the Tapu explored in Figures 4.41-4.44, authors own drawing

Figure 4.46 Tapu Map Overlay of Figures 4.11-4.15, author's own drawing

Figure 4.47 Tapu Map Overlay of Figures 4.11-4.15, with areas where tapu is cleansed within the site inscribed into the drawing, author's own drawing

Figure 4.48 Plan of Conceptual Outcome Generated from Conceptual Image Analysing the Presence of Tapu and Noa within Experiment Two's Site, author's own drawing

Figure 4.49 Exploded Isometric of Conceptual Outcome Generated from the Analysis of the Presence of Tapu and Noa within Experiment Two's Site, author's own drawing

Figure 4.50 Perspective of Conceptual Outcome Generated from Conceptual Image Analysing the Presence of Tapu and Noa within Experiment Two's Site, author's own drawing

Figure 4.51 Section of Conceptual Outcome Generated from Conceptual Image Analysing the Presence of Tapu and Noa within Experiment Two's Site, author's own drawing

Figure 5.1 Diagram of Programmatic and Spatial Qualities of Design One, author's own drawing

Figure 5.2 Plan, Design One, author's own drawing

Figure 5.3 Interior Perspective of Parents Bedroom, Design One, author's own drawing

Figure 5.4 Interior Perspective of Children's Bedroom, Design One, author's own drawing 
Figure 5.5 Interior Perspective of Children's Bed and Shelves, Design One, author's own drawing

Figure 5.6 Interior Perspective of Kitchen and Dining Area, Design One, author's own drawing

Figure 5.7 Interior Perspective of Lounge/Play Area, Design One, author's own drawing

Figure 5.8 Exterior Perspective of Outdoor Living Area, Design One, author's own drawing

Figure 5.9 Exterior Perspective of Outdoor Umu Cooking Area, Design One, author's own drawing

Figure 5.10 Exterior Perspective of Outdoor Living and Cooking Area, Design One, author's own drawing

Figure 5.11 Latitudinal Section A-A', Design One, author's own drawing

Figure 5.12 Latitudinal Section B-B', Design One, author's own drawing

Figure 5.13 Exploded Isometric, Design One, author's own drawing

Figure 5.14 Longitudinal Section C-C', Design One, author's own drawing

Figure 5.15 Front Street Elevation, Design One, author's own drawing

Figure 5.16 Isometrics and Elevations Detailing Operation of In-built Furniture, Design One, author's own drawing

Figure 5.17 Interior Perspective of Te Reo Writing and Dining Area, Design One, author's own drawing

Figure 5.18 Exterior Perspective of Te Reo Writing and Outdoor Sitting Area, Design One, author's own drawing

Figure 5.19 Plan, Design Two, author's own drawing

Figure 5.20 Latitudinal Section A-A', Design Two, author's own drawing

Figure 5.21 Longitudinal Section B-B', Design Two, author's own drawing

Figure 5.22 Interior Perspective of Shower Room, Design Two, author's own drawing

Figure 5.23 Exterior Perspective of Rear Entrance, Design Two, author's own drawing

Figure 5.24 Exploded Isometric, Design Two, author's own drawing

Figure 5.25 Interior Perspective of Washroom, Design Two, author's own drawing

Figure 5.26 Interior Perspective of Cooking and Dining Area, Design Two, author's own drawing

Figure 5.27 Front Elevation Behind Boundary Fence, Design Two, author's own drawing

Figure 5.28 Interior Perspective of Children's Bedroom, Design Two, author's own drawing

Figure 5.29 Interior Perspective of View-shaft Between Bedrooms, Design Two, author's own drawing

Figure 5.30 Interior Perspective of Guest Bedroom, Design Two, author's own drawing

Figure 5.31 Interior Perspective of Living Area, Design Two, author's own drawing

Figure 5.32 Interior Perspective of Bedroom Courtyard, Design Two, author's own drawing

Figure 5.33 Interior Perspective of Hallway Courtyard, Design Two, author's own drawing

Figure 5.34 Front Street Elevation, Design two, author's own drawing

Figure 5.35 Exterior Perspective of Front Street Elevation, Design Two, author's own drawing

Figure 5.36 Exterior Perspective of Street Frontage, Design Two, author's own drawing 
Figure 5.37 Exterior Perspective of Outdoor Living with House Wall Shutter Systems Open, Design Two, author's own drawing

Figure 5.38 Night-time Exterior Perspective of Entrance and Outdoor Outdoor Living with House Wall Shutter Systems Mostly Closed, Design Two, author's own drawing

Figure 5.39 Exterior Detail Perspective Of Te Reo Writing, Outdoor Living Area, Design Two, author’s own drawing Figure 5.40 Interior Detail Perspective of Te Reo Writing, Washroom, Design Two, author's own drawing 



\section{Introduction}

The ability of architecture to mediate cultural identities and prescribe spatial practices empowers it as it provides an avenue through which it can persuade, legitimate, or dominate physical space; not only in terms of how it is conceived of but also how the social interactions the occur within space are ordered. ${ }^{1}$ In other words architecture allows ideology, knowledge and therefore power to mediate space, both physically and culturally. This realisation must result in a heightened questioning and critique of how historic and contemporary architecture functions as a socio-spatial object, and challenge the treatment of architecture as a field autonomous from social and political influence. This is particularly important in countries such as New Zealand, that find their roots in a colonial past, where space, land, and building are at the forefront of cultural appropriation and domination.

This thesis first seeks to investigate how the New Zealand State House, and the mechanisms used to represent it, mediated colonial and imperial narratives of space, culture, and society. Second it seeks to investigate the possibilities of creating a new, what will be termed post-colonial, position within contemporary residential architecture in New Zealand. The investigation is formed by challenging the narratives mediated by the State House, and the mechanisms used to represent it, with alternative social and cultural narratives.

Chapter one reviews relevant architectural and post-colonial literature on the topic (Fig.1.1). It first establishes the epistemological and ontological position of the research through the work of Bourdieu and Lefebvre, as well as Foucault, Bhabha, and Said. Second it uses the same authors to generate theoretical frameworks that guide the design research undertaken within the thesis.

Chapter two is concerned solely with the first aim of this research. Part case study, part historical survey, the chapter investigates the State House, and the mechanisms used to represent it, as social and cultural productions. It investigates how the State House, and the mechanisms used to represent it, occupy a colonial position, mediate colonial spatial narratives, and discusses how they influenced the development of New Zealand's spatial and cultural identity. ${ }^{2}$ Section one introduces the history of the State House and describes it. Section two then analyses the State House, and the mechanisms of representation used within State House developments, in a similar manner to Foucault and Said, exposing their mediation of imperial and capitalist ideologies that supported colonial spatial appropriation. ${ }^{3}$ The narratives investigated follow two themes:

- The Politics of Representation: the State House, colonial mechanisms of representation, and functionalist suburban and architectural design

- The Imperial Cultural Object: the State House as an affirmation of Pākehā civility and superiority

Chapters three, four, and five are concerned with the second aim of the thesis, investigating the possibilities for creating a new post-colonial architectural position through a critique of the colonial narratives of the State House and the architectural mechanisms used to represent it discussed in Chapter two. Chapter three follows Bhabha's advocacy for the performative, and Lefebvre's advocacy for representational and differential space, by investigating the ways I which inhabitants have appropriated State House environments since their were initial development. ${ }^{4}$ Through the analysis of empirical evidence of current spatial practices within the area, the chapter defines a series of specific criteria that are used in conjunction with the concepts developed within the design experiments detailed in Chapter four to develop and resolve the outcomes to more appropriate functional and architectural levels as shown in Chapter five.

1 Findley, xiii, 2-6 193, 206-207, 210, also James, Paul, 23-27, Hillier and Hanson, 1-5

2 The State House was chosen because (a) it was developed by the New Zealand government and is therefore inherently linked to political and colonial power, (b) the prevalence of state housing on the landscape of New Zealand, in terms of the time frame of development, scale of production, and political importance, makes it a significant influence on New Zealand society, (c) the major period of State House production (from the end of World War II up until the mid-1970s) coincided with a period of mass urban migration of Mãori and immigration of Pacific peoples, many of whom relied upon State Houses due to discrimination in the private housing sector, (d) areas, such as Porirua, New Zealand's largest state housing development, are densely populated with State Houses, and remain largely unchanged since their initial development, providing strong examples of how both individuals and larger communities relate to, interact with, and live within State House architectural and urban environments both socially and physically, historically and contemporarily.

3 This method is also advocated by Lefebvre, who argues that "we should have to study not only the history of space, but also the history of representations, along with that of their relationships - with each other, with practice, and with ideology." Lefebvre, The Production of Space, 42

4 In essence, this is a process of revealing how occupants "instead of installing themselves in their containers, instead of adapting to them and living in them 'passively', they decided that as far as possible they were going to live 'actively'. In doing so they showed what living in a house really is: an activity. They took what had been offered to them and worked on it, converted it, added to it." Lefebvre, Lived-in Architecture: Le Corbusier's Pessac revisited, n.p. also Stanek, 165 
Chapter four contains two design experiments that extend from the work of Bhabha and Said, and engage cultural narratives that were previously suppressed or excluded by the narratives mediated within the State House and the mechanisms used to represent it. ${ }^{5}$ The first experiment engages a Māori architecture with a colonial mechanism by translating collective depictions of wharenui into sectional, planar, and axonometric architectural representations. The second experiment engages a colonial architecture with a Māori mechanism by reading the architecture of a State House through a conceptual understanding of tapu and noa developed by Michael Shirres.

Chapter five describes, conveys, and analyses the final design outcomes, before Chapter six reflects upon the thesis as a whole, as well as its implications for further research and design practice.

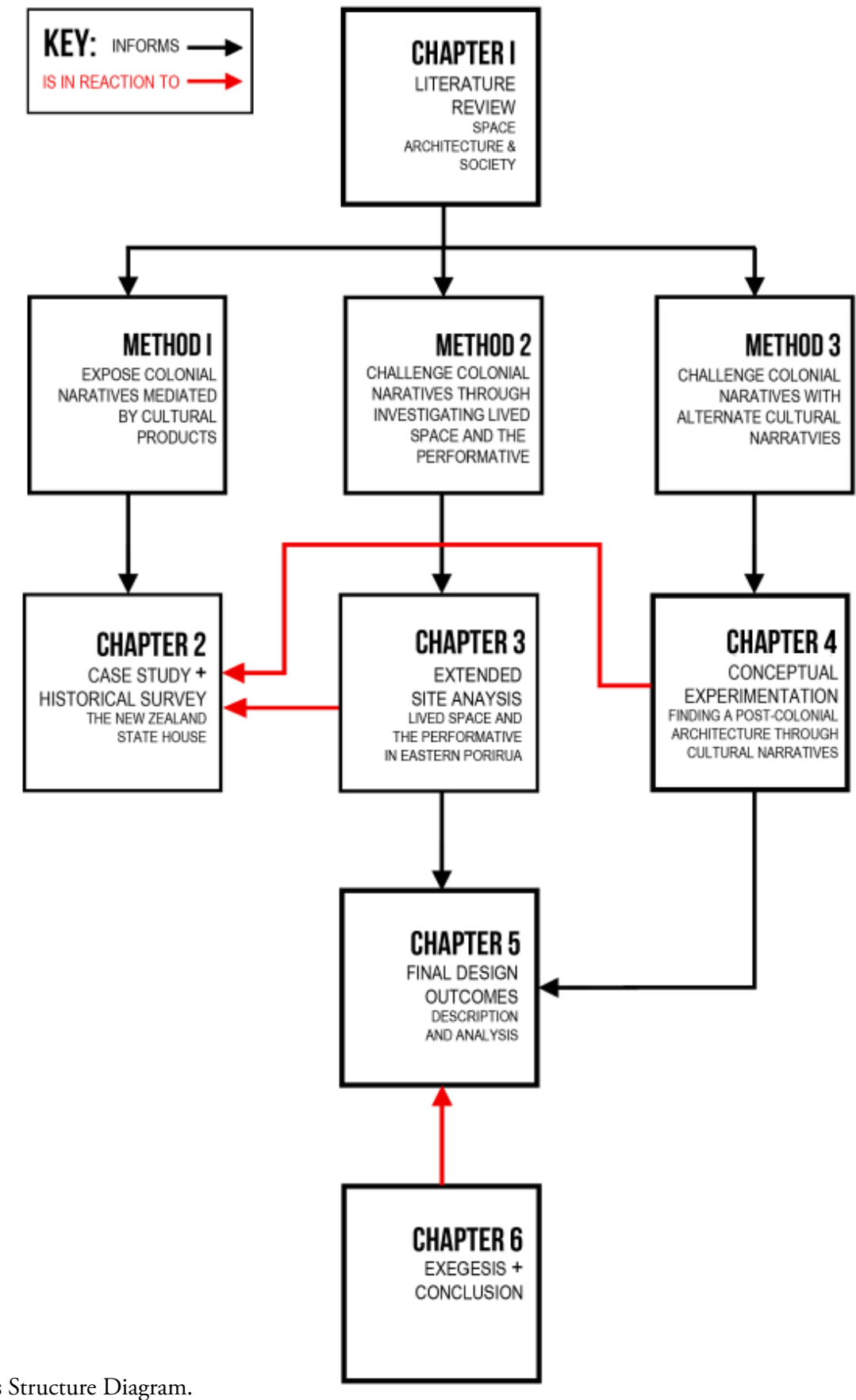

Figure 1.1 Thesis Structure Diagram.

5 Said, 78, also Bhabha, 163-165 




\section{Chapter One: Literature Review: Space, Architecture, and Society}

In Discipline and Punish, Foucault analysed how institutional typologies such as the panoptic prison, industrial factory, and military barracks mediated the "idea of governmentality, that is, the theory relating types of power to apparatuses of constitution and regulations of populations and individuals." Discipline and Punish, clearly, is not a study of architecture but a study of how architectural typologies emerged in order to physically concretise changes in ideology concerning the human body, and the surveillance and spatial order necessary to control it. Consequently, architecture cannot be seen to operate within a vacuum but from within a social, cultural and political field of play which is both influential upon architecture and influenced by architectural creation and the socio-spatial practices of people in everyday life.

Said discusses cultural products in the same manner as Foucault, but seeks to understand how colonial powers used cultural products to (a) represent space in a manner that supports colonial spatial appropriation (b) create connections between individuals and collective social identities and spatial practices and (c) degrade and control the ability for indigenous peoples to maintain physical, social and symbolic control over land, space and cultural products. Said begins Culture and Imperialism with the premise that colonisation is not a simple act of acquisition, but is supported by ideological formations that include notions that certain territories and people require and beseech domination, as well as knowledge affiliated with domination. ${ }^{7}$ Said, like Foucault, re-connects the "structures of a narrative to the ideas, concepts, experiences from which it draws support," ${ }^{8}$ and takes account of both the processes of colonisation and resistance to it. ${ }^{9}$

While the work of Foucault and Said presents specific examples of how cultural objects embody and mediate social and cultural ideologies, Bourdieu provides a clearer understanding of the underlying social relationship between power, architecture, and people within modern society through his formula (habitus) (capital) $\}+$ field = practice." 10

For Bourdieu socio-spatial practices are learnt over time through a web of socio-spatial predispositions, which he terms 'habitus'. Bourdieu argues that habitus functions below the level of consciousness and embeds:

What some would mistakenly call values in the most automatic gestures or the apparently most insignificant techniques of the body - ways of walking or blowing one's nose, ways of eating or talking - and engage the most fundamental principles of construction and evaluation of the world. ${ }^{11}$

It is not just the habitat, the physical space, which designates the ordering of action but a combination of the habitat with the habits, the social actions that become embedded within particular spatial orders that prescribe how we act within a given space such as a panoptic prison, factory, library, or suburban house. ${ }^{12}$

Bourdieu argues that forms of cultural and social capital (i.e. educational capital through scholarly institutions, cultural capital through "learning cultural skills, whether table manners or the art of conversation, musical culture or the sense of propriety, playing tennis or pronunciation") ${ }^{13}$ are accumulated and invested in the 'game of culture' in order to define the 'conditions of existence' which legitimate cultural and social predispositions. ${ }^{14}$ Habitus is, therefore, intimately linked with class, due to the differences in volume (a set of actually usable resources and powers: economic capital, cultural capital, and social capital) and composition of capital that is distributed to and maintained by different class factions. ${ }^{15}$ Capital extends Bourdieu's equation beyond structuralism as it signifies people as social agents of classification and production.

\section{Venn, 246}

7 Said states "we must therefore read the great canonical texts, and perhaps also the entire archive of modern and pre-modern European and American culture, with an effort to draw out, extend, give emphasis and voice to what is silent or marginally present or ideologically represented in such works." Said, 78-79, also 8

8 Said, 79

9 Said, 79

10 Bourdieu, 101

11 Bourdieu, 466

12 Dovey, 20

13 Bourdieu, 70

14 Bourdieu, 12, 53-54, 114-115, 303

15 Bourdieu, 70-71, 114 
Bourdieu's notion of field represents the different space(s) of cultural production within which the 'game of culture' is played. ${ }^{16}$ Fields emphasise collectivism because they become controlled by sets of agents with "homogenous conditions of existence imposing homogenous conditionings and similar practices; and who possess a set of common properties." 17

By revisiting Bourdieu's equation ' $\{$ (habitus) (capital) $\}+$ field = practice', a picture of the operation of architecture within society, and its relationship to institutions of power, architects, and inhabitants, is gained. Particular spatial practices, orders, and aesthetic and formal tastes are related, defined by cultural ideologies which, for example, may characterise them as moral, civilised, or inferior and uncivilised. These seemingly truthful, but in reality, arbitrary and stereotypical, distinctions become embedded within architectural productions. Such distinctions become particularly poignant when the production of architecture is heavily controlled by governments or other political groups, as the architectural object becomes a means to support and legitimise ruling group's positions of power and cultural ideologies.

Bourdieu's equation defines both the architect, and the inhabitants of architecture, as agents who, through practice, interact with, and in some cases challenge, the same sets of predispositions that govern the field. ${ }^{18}$ Bhabha's work can be situated within Bourdieu's framework and specifically discusses the formation of colonial cultural narratives and identities. Bhabha introduces a range of concepts, although his most cited concept, hybridity, stands for a liminal position between two cultures generated through cultural difference. ${ }^{19}$ Hybridity is:

The name for the strategic reversal of the process of domination through disavowal (that is, the production of discriminatory identities that secure the 'pure' and original identity of authority) that through a demonstration of cultural difference introduces denied knowledges to "the dominant discourse and estrange that basis of its authority - its rules of recognition ... the difference of cultures can no longer be identified or evaluated as objects of epistemological or moral contemplation: cultural differences are simply there to be seen or appropriated. ${ }^{20}$

Bhabha deepens the understanding of Bourdieu's equation by relating it to colonial power and socio-spatial appropriation, highlighting methods through which the dominant characteristics of cultural fields can be critiqued and challenged. ${ }^{21}$

Lefebvre further deepens Bourdieu's equation by outlining the parameters of the 'field' of space in modern capitalist society. He forms a spatial triad with the goal of rendering intelligible qualities of space (both physical and social) that are both perceptible and imperceptible to the senses, namely:

1. Representations of space (or) the conceived,

2. Representational spaces (or) the lived, and

3. Spatial practice (or) the perceived. ${ }^{22}$

16 Dovey, 39-41

17 Bourdieu, 101, also Dovey, 41

18 Jones, $17-18$

19 Bhabha, 160-164

20 Bhabha, 159-163

21 This differentiates cultural difference from cultural diversity, which Bhabha argues is a containment of true diversity because it classifies and totalises cultures within a system controlled by the dominant power; the muse imaginaire where cultures can be located historically and geographically and appreciated as if they were exhibits in a museum. Bhabha, 34-36, 163-165

22 Stanek suggests that the distinction between the two groups of terms reflects two perspectives within Lefebvre's Marxist framework, the phenomenological description of urban life (the perceived-conceived-lived) and the semiology of the urban environment (the spatial practice-representations of space-spaces of representation). Stanek, 128-129. 
The first point - representations of space - refers to space as it is conceived of; existing on the page, in the head rather than in the body. ${ }^{23}$ Lefebvre sees representations of space as controlled through professional and institutional discourse, defining them as abstractions of reality and perspectives of truth. ${ }^{24}$ Lefebvre argues that representations of space is the dominant triadic point within capitalist society ${ }^{25}$, and its abstract nature denies qualitative space and the right to what Lefebvre terms 'differential space'. ${ }^{26}$ Representations of space are therefore intimately linked to power and ideology as they can be used to persuade, to legitimate, or to dominate physical reality and the ability of inhabitants to appropriate it. ${ }^{27}$

The second point - representational spaces - is the lived space of everyday experience. ${ }^{28}$ Representational spaces are felt rather than thought, and overlay physical space, making symbolic use of its objects. ${ }^{29} \mathrm{Within}$ western societies, representational spaces are dominated by and subordinate to representations of space, and are therefore passively experienced. ${ }^{30}$ However within representational spaces Lefebvre suggests is a resistance to representations of space as it "embraces the loci of passion, of action and of lived situations $\ldots$ it is essentially fluid and dynamic" ${ }^{31}$ In the same manner conceived of by Bourdieu, representational spaces characterise people as active producers of space that can reinforce or challenge ingrained predispositions and ideologies concerning architecture, simply by engaging with it in their everyday lives.

Links to Bhabha are formed once more here through his concept of the pedagogical and the performative. The pedagogical represents the pre-given past through which we recognise our identity. ${ }^{32}$ The perfomative on the other hand "refers to the entire set of actions (artistic, commercial, political, religious etc.) carried out by people in their everyday life." 33 The tension between the pedagogical and the performative turns the classification of a 'people' into a problem of knowledge, challenging the formation of modern social authority. ${ }^{34}$

For Bhabha the performative "introduces a temporality of the "in-between" 35 , a "liminality of the people - their double inscription as pedagogical objects and performative subject" forces a disavowal from the discourse of historicism. ${ }^{36}$ In a similar manner to Lefebvre, who sees the potential for representational spaces to challenge representations of space, Bhabha sees the potential for the performative, the entire set of actions carried out by people in their everyday life, to challenge pedagogical 'truths' about how people live and how they identify themselves within space.

23 Lefebvre, The Production of Space, 38-46

24 Lefebvre states "Are they [representations of space] then true or false? The question does not always have a clear meaning: what does it mean, for example, to ask whether perspective is true or false?" Lefebvre, The Production of Space, 41, also 38-39 25 Lefebvre introduces abstract space, stating "it would be true to say that the place of social space as a whole has been usurped by a part of that space endowed with an illusory special status- namely, the part which is concerned with writing and imagery, underpinned by the written text (journalism, literature), and broadcast by the media; a part, in short, that amounts to abstraction wielding awesome reductionistic force vis-à-vis 'lived' experience." Lefebvre, The Production of Space, 52

26 For Lefebvre the term 'differential space' is relational to 'abstract space'. He argues "Given that abstract space is buttressed by non-critical (positive) knowledge, backed up by a frightening capacity for violence, and maintained by a bureaucracy which has laid hold of the gains of capitalism in the ascendant and turned them to its own profit, must we conclude that this space will last forever? ... Whatever traces of vitality remained would have a wasteland as their only refuge. From a less pessimistic standpoint, it can be shown that abstract space harbours specific contradictions. Such spatial contradictions derive in part from the old contradictions thrown up by historical time. These have undergone modifications, however: some are aggravated, others blunted. Amongst them, too, completely fresh contradictions have come into being which are liable eventually to precipitate the downfall of abstract space. The reproduction of the social relations of production within this space inevitably obeys two tendencies: the dissolution of old relations on the one hand and the generation of new relations on the other. Thus, despite - or rather because of - its negativity, abstract space carries within itself the seeds of a new kind of space. I shall call that new space 'differential space', because inasmuch as abstract space tends towards homogeneity, towards the elimination of existing differences or peculiarities, a new space cannot be born (produced) unless it accentuates differences." Lefebvre, The Production of Space, 52

27 This aligns with more contemporary views on the sociology of architectural practice. For example, Findley argues that "architecture's primary role relative to power has always been to give physical built form to political, cultural, or religious ideas; to make visible invisible values, ideology and perspective." Findley, 193, also Jones, Paul, 23-27, Dovey, 39-41

28 Lefebvre, The Production of Space, 38-46

29 Lefebvre, The Production of Space, 39, 41

30 Lefebvre, The Production of Space, 39-40

31 Lefebvre, The Production of Space, 42

32 Hernandez provides a good summary of the pedagogical, stating that it "corresponds with the official project of the nation as historicity and self-generation... [It] refers to all those instruments used to inculcate a sense of national identity and belonging, the means through which we recognise ourselves as members of an imagined community." Hernandez, 113

33 Hernandez, 113-114

34 Bhabha, 209

35 Bhabha, 212

36 Bhabha, 217 
The third point in Lefebvre's triadic dialectal is spatial practice. ${ }^{37}$ Spatial practice is more encompassing and totalising, but Lefebvre is vague in answering clearly how spatial practice is a distinct triadic point. ${ }^{38}$ He does however clearly define the function of spatial practice within capitalist societies, arguing that it is a regulator of everyday life, providing the link "between daily reality (daily routine) and urban reality (the routes and networks which link ... places ... for work, 'private' life and leisure)." ${ }^{39}$

Each point within Lefebvre's triad implies a distinct method for creating a new architectural position within modern capitalist society. Representations of space imply the critique of architectural mechanisms of representation in terms of how they abstract reality; representational spaces imply the possibility of challenging the abstract realities of representations of space through researching how space is appropriated symbolically and physically; spatial practice implies an avenue for analysis into ways in which social and urban scale structures physically and socially prescribe the actions and perceptions of people(s).

The theorists above not only situate architecture and define its role within established systems of power, but also provide methods through which contemporary New Zealand architectural practice can critique established colonial and western positions in order to reflect shifts in social power within New Zealand society. These suggested methods of resistance are discussed further below and structured into frameworks that guide the design experimentation within the later chapters of this thesis.

\footnotetext{
37 Lefebvre introduces spatial practices as follows: "The spatial practice of a society secretes that society's space; it propounds and presupposes it, in a dialectal interaction; it produces slowly and surely as it masters and appropriates it. From the analytic standpoint, the spatial practice of a society is revealed through the deciphering of its space". Lefebvre, The Production of Space, 38. 38 Stanek provides the best summary of modern interpretations of Lefebvre's triad, stating: In the first book about Lefebvre's theory to be published in English, Rob Shields defined Lefebve's spatial practices as "space perceived (perçu) in a commonsensical mode"; the representations of space as "discourses on space" or "the discursive regimes of analysis, spatial planning professions and expert knowledges that conceive of space (l'espace conçu)"; and finally, the spaces of representation as "discourses of space," "space as it might be, fully lived space (l'espace vécu)": the spaces of representation form the social imaginary. Stuart Eldon confirmed this reading and explained that, according to Lefebvre, the perceived space is physical space; the conceived space is a mental construct and an imagined space; and the lived space is that which is modified in everyday lifeand this distinction is the basis for the conceptual triad of spatial practice, representations of space, and space of representation. The analysis of Andy Merrifield was developed along similar lines: while spatial practices "secrete" society's space and have "close affinities with perceived space," the representations of space are described as conceptualizations, or "conceived" space, and spaces of representation are the lived spaces of everyday life. The most advanced discussion about the triads of space can be found in the book Stadt Raum und Gesellschaft: Henri Lefebvre und die Theorie der Produktion des Raumes, by Christian Schmid, which begins with identifying three "fields" distinguished by Lefebvre: the physical field of nature and materiality, delineated in a practical and sensual way; the mental field of logics and formal abstractions, defined by mathematics and philosophy; and the social field, "the field of projects and projections, of symbols and utopias, of the imaginaire and ... the desir. They intersect in the processes of the production of space: the material production, of the spatial practice, which "produces the perceived aspect of space"; the production of knowledge, and thus representations of space and conceived space; and the production of meaning, "which is related to spaces of representation and which produces an experienced, or lived, space.

Stanek, 128-130.
}

39 Lefebvre, The Production of Space, 38. 


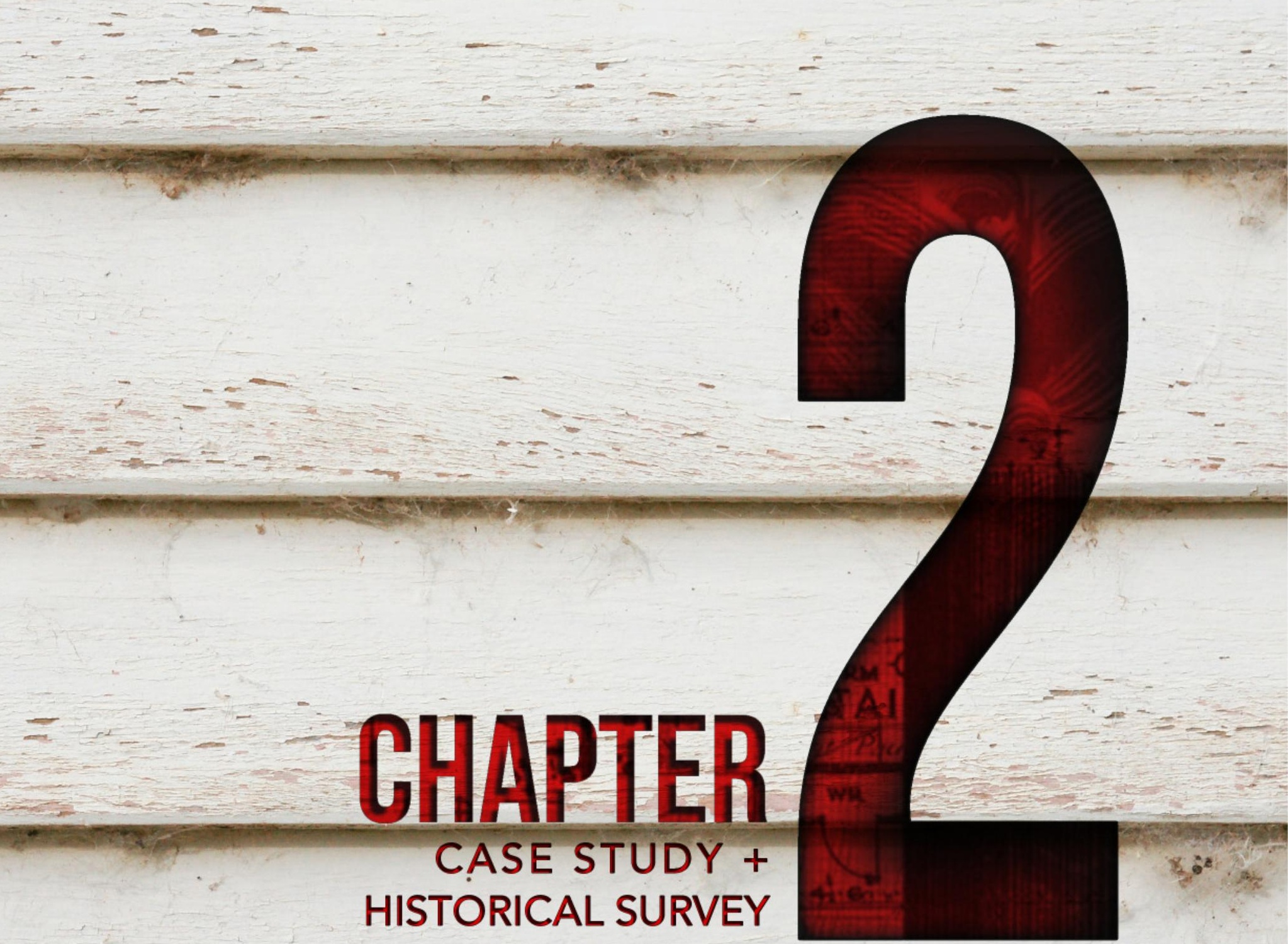

THE NEW ZEALAND

STATE HOUSE 


\section{Chapter Two: Historical Survey/Case Study: An Analysis of the New Zealand State House}

\section{Section One: An Introduction to the New Zealand State House}

This section provides an introduction to the New Zealand State House to support its analysis in section two. It is intended to provide an understanding of the development of the New Zealand State House through successive governments, the changes in scale of its production, and to describe its architectural characteristics. ${ }^{40}$

\section{The State House as We Know it: Labour's State Housing Programme 1935-1949}

In 1936, on the back of the 1935 housing survey and mounting public pressure ${ }^{41}$, Labour Finance Minister Walter Nash announced that 5000 state rental houses would be erected under the Housing Act at a cost of three million pounds. ${ }^{42}$ Although World War II limited output between 1941 and 1944, between 1937 and 1949, 33,766 building permits were issued for state rental houses in New Zealand, making up just under $30 \%$ of the 115,732 total dwelling permits issued during that time. ${ }^{43}$ Of these only $1.5 \%$ were apartment flats, with the overwhelming majority being detached and semi-detached (two-four unit) two or three bedroom suburban houses. ${ }^{44}$

Almost without exception, the plan contained a small front porch containing the front entry into a small hall connected to the corridor. A second porch would be located at the rear or side of the house, and either connected to the kitchen, laundry or less directly into the central corridor. Using Hillier and Hanson's gamma genotype analysis, ${ }^{45}$ confirms that, although the plans may differ in terms of room size and location in order to best make use of sunlight, the underlying spatial structure of state, and also Māori Affairs, housing was extremely consistent (Fig.2.1-2.2).

Analysis reveals that the corridor is the most dominant space in the State House, controlling access and connections between all the functioning rooms and public and private zones. Although in some aspects (such as solar design, the introduction of the living room in place of the parlour, and the incorporation of the dining space into the kitchen area), state housing plans reflected contemporary ideas, their interior spatial structure is more similar to those seen in earlier New Zealand houses, such as the Victorian villa and Georgian revival cottage, rather than modernist house plans in Europe, or the ringed systems of the Californian Bungalow that was also used at the time state housing was originally developed (Fig.2.3-2.6). This socio-spatial structure stayed fairly constant throughout the twentieth century, with the two-storey multi-units adding the vertical division of private bedrooms from family living, dining and kitchen areas (Fig.2.7).

The planning of state housing schemes under Labour was dominantly suburban, as Firth stated "New Zealanders want elbow room. This point of view is reflected in the spreading suburbs ... the detached house set in its own grounds is in general an ideal type of accommodation for New Zealand conditions and habits of life." ${ }^{46}$ Typical suburban plans in Firth's State Housing in New Zealand depict curving main roads and cul-de-sacs enclosing near identical rectangular sections of land (Fig.2.8-2.10). ${ }^{47}$

40 New Zealand's history of state sponsored housing dates back to 1894 (first government loans given to citizens for the construction of homes on suburban land), and the government first directly financed the construction of State Houses in 1905 under the Worker's Dwellings Bill. However 1935 marks not only the year of New Zealand's first Labour-led government, but also the introduction of the 'State House' as most New Zealanders recognize and know it. Schrader, "Labour at Home", 129-130, also Schrader, We Call it Home, 22-24

41 Schrader, "Labour at Home", 33-34, also Isaac and Olssen, 107-124

42 Schrader, We Call it Home, 35

43 Firth, 67

44 Gatley, 140

45 Hillier and Hanson, 97, 122, also Hillier, 20-27, 71-77

46 Firth, 14

47 Firth, 14 


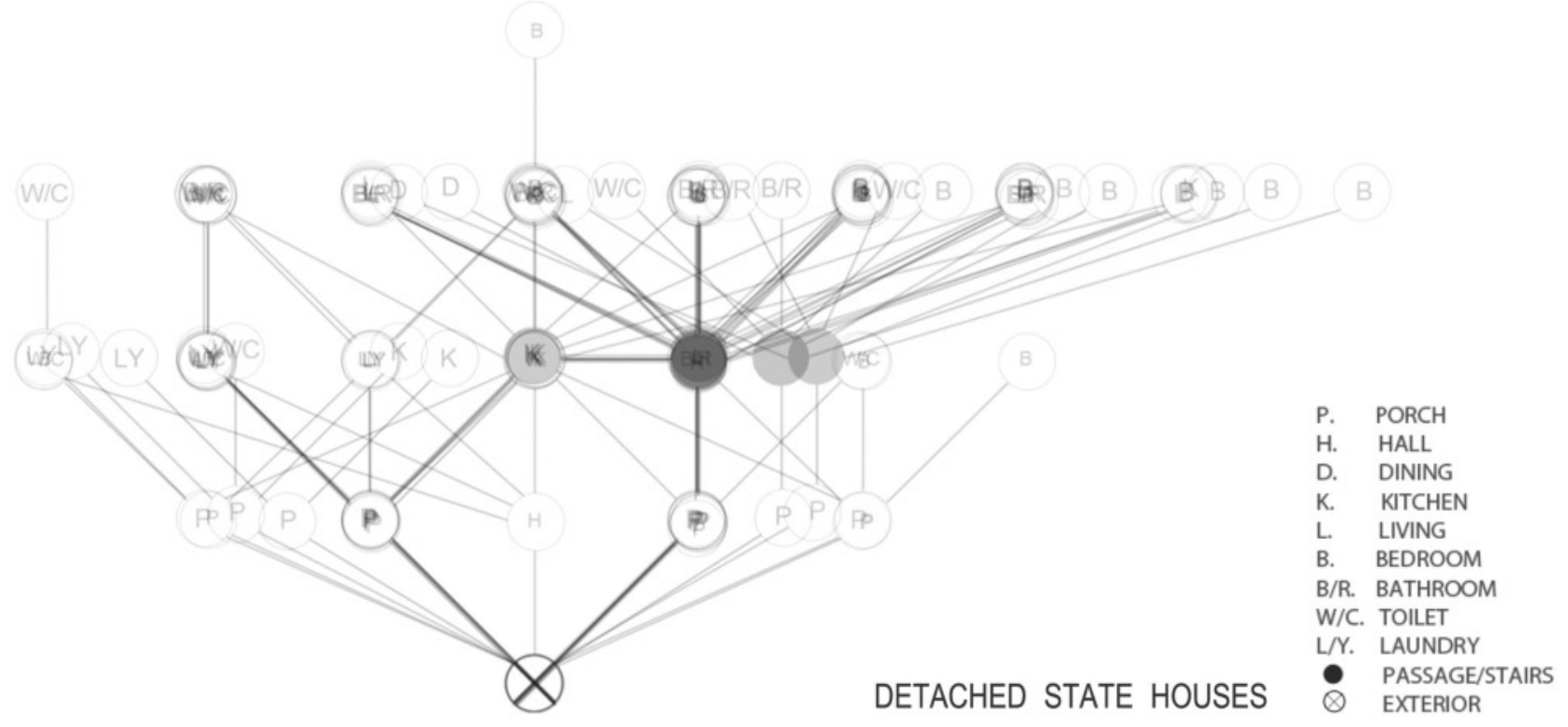

Figure 2.1 Gamma Analysis Overlays of Detached State House Plans. The $\bigotimes_{\text {symbol is the exterior environment. Other symbols }}$ represent different spaces within the house. The symbol represents a passage, stairs, or hallway between two spaces. Lines show which spaces within the house are connected to each other. Detached State House gamma diagrams follow a prescribed pattern of access from the exterior being provided through two small porches, which connect to the main hallway and often kitchen or laundry area. Access to bedrooms is gained through the hallway, although in plans produced after 1949, access to one bedroom is sometimes provided through the lounge. The hallway therefore clearly demarcates the boundary between the public and private spaces of the house.

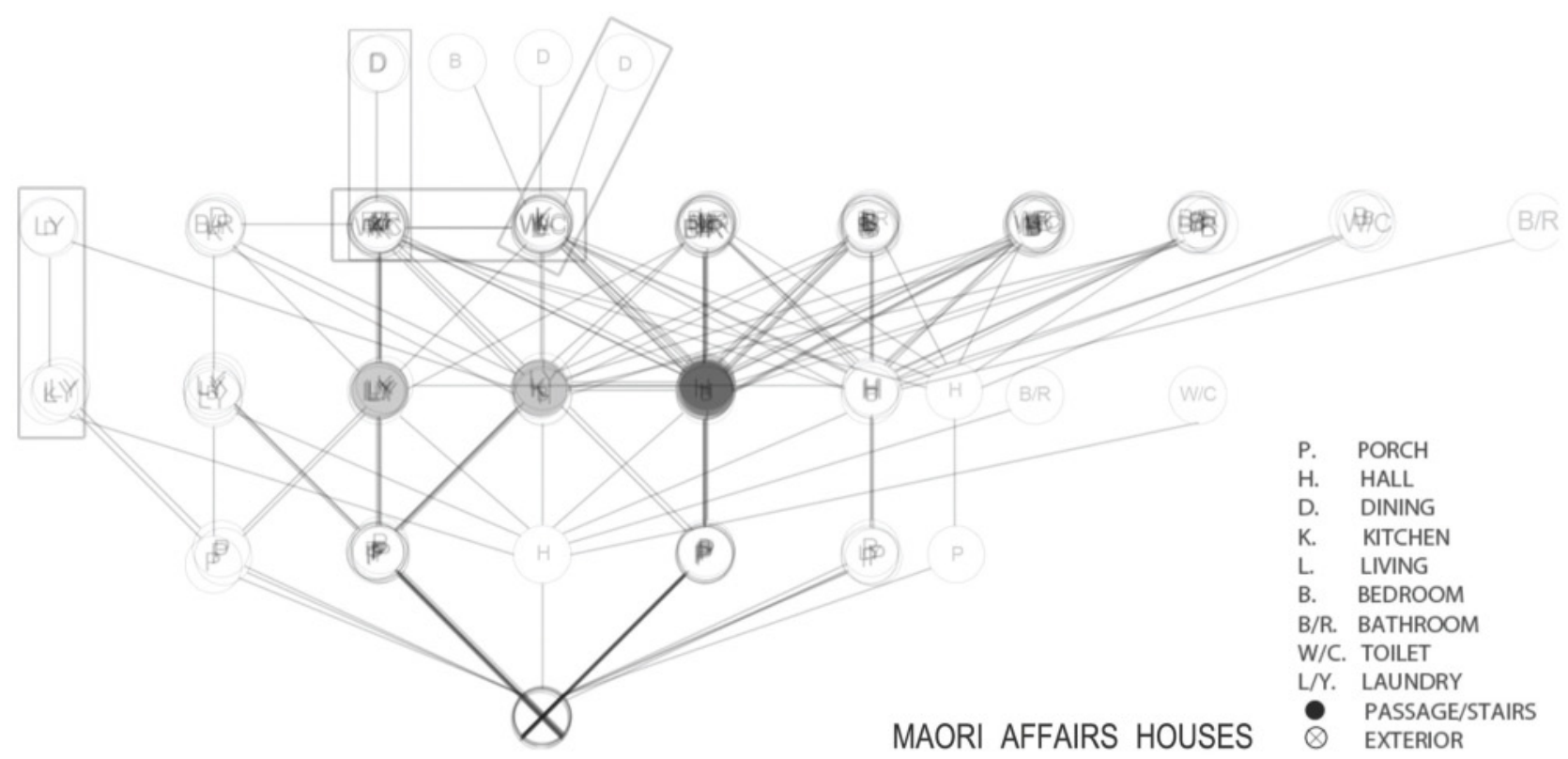

Figure 2.2 Gamma Analysis Overlays of Department of Māori Affairs House Plans. The diagram conveys the similarity in spatial structure to normal Department of Housing Construction State Houses. The differences are limited to the provision of an extra bedroom, and sometimes the separation of laundry and bathroom spaces from the kitchen, although this was often done in Department of Housing Construction Houses as well. 
MODERN HOME No. 147

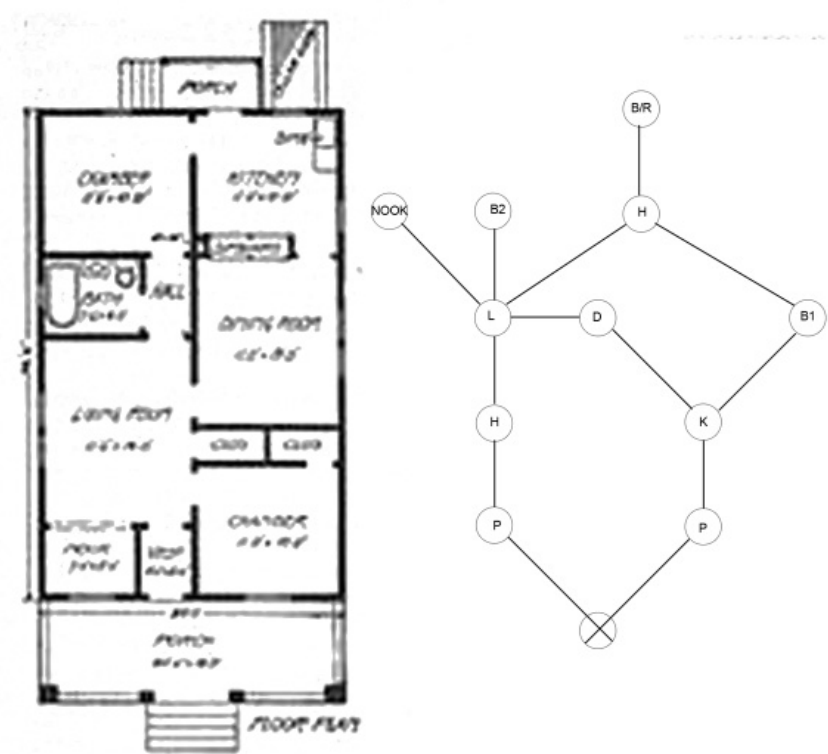

Figure 2.3 Plan and Gamma Analysis of Bungalow "Modern Home No.147". Californian Bungalow plans were more 'ringed' and 'deeper' than State House Plans, with spaces structured in looped patterns, eliminating the need and presence for a central corridor or hallway.
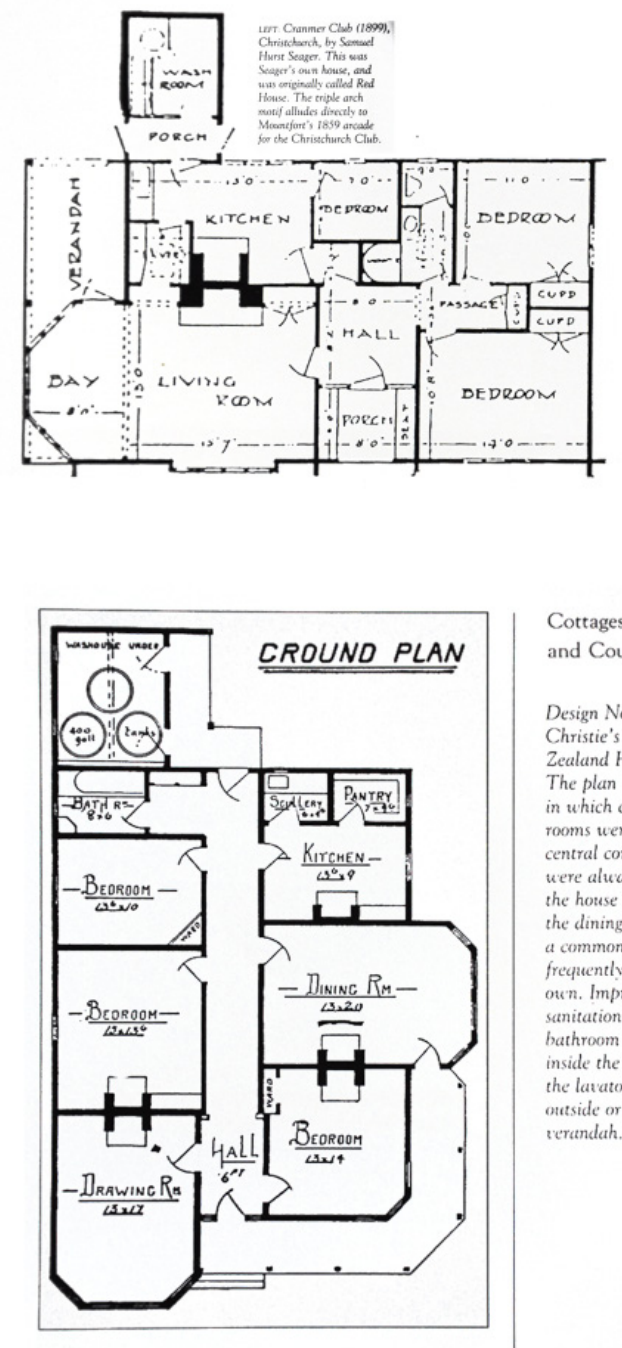

\section{Cottages, Villas} and Country Houses

Design No. 44 from James Christie's catalogue of New Zealand Homes (c. 1910). The plan illustrates the way in which clearly separated rooms were entered from a
central corridor. Kitchens were always at the back of the house but by the 1890s the dining room had become a common feature and was
frequently giten a bay of its frequently giten a bay of
outn. Improtements in sanitation allowed the athroom to be brought inside the house, although the lavatory remained outside or in the back terandah
MODERN HOME No. 144
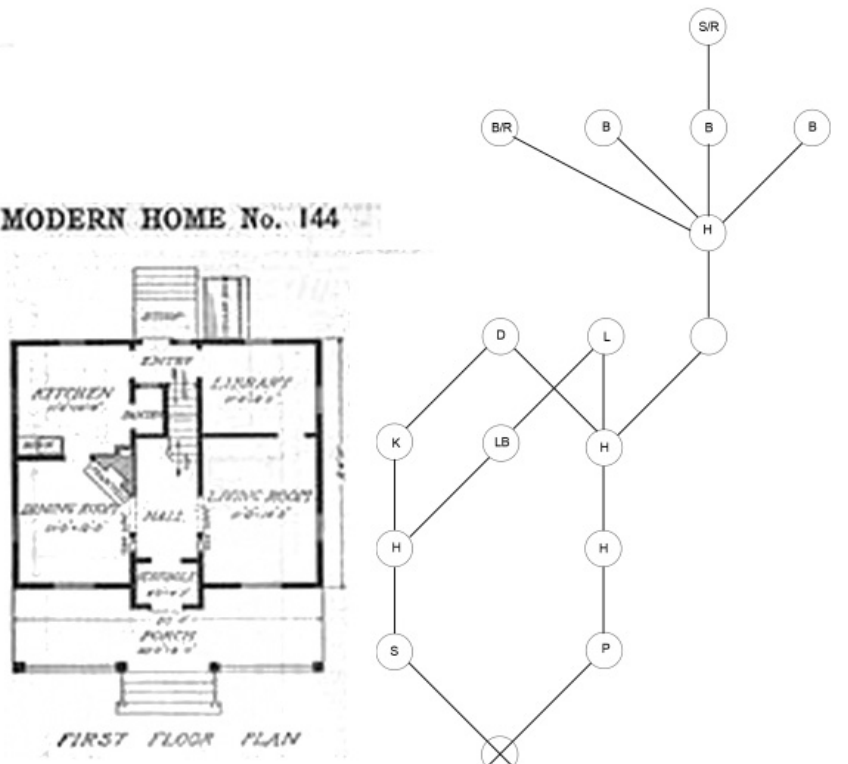

Figure 2.4 Plan and Gamma Analysis of Bungalow "Modern Home No.144". This two story Californian Bungalow is more similar to state house multiunits than single story bungalows were to detached state houses due to the introduction of a central hall leading of the stairs. However the spatial structure is still deeper and in a more defined ring than was typical of state house multiunits.
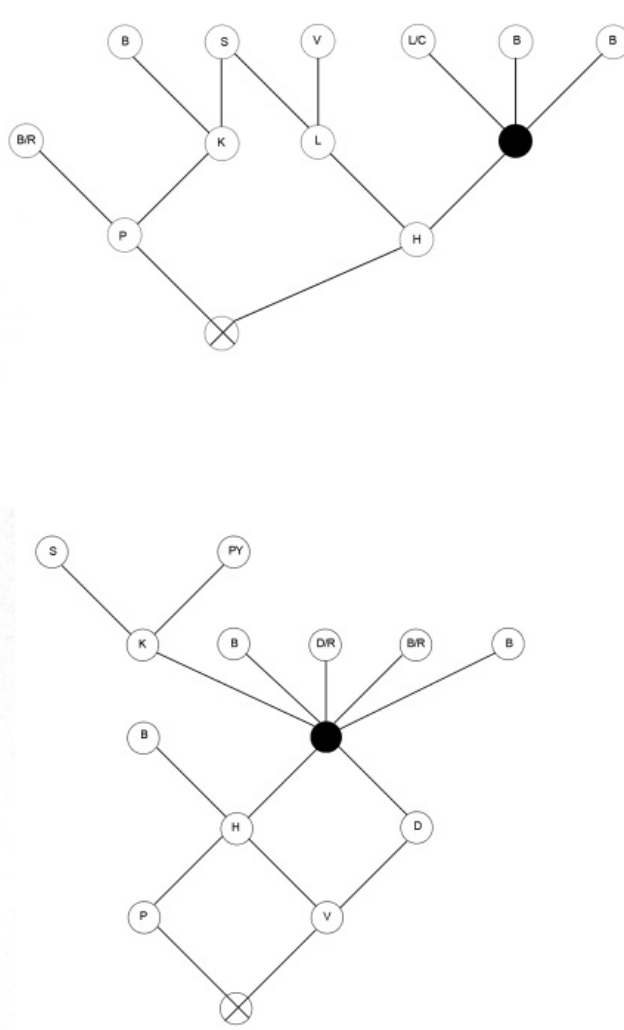

Figure 2.5 Plan and Analysis of Samuel Hurst Seager's "Cranmer Club". This early twentieth century house shows its similarity to state house plans in its elimination of a formal dining room and the use of a hallway to clearly demarcate the boundary between public and private spaces.

Figure 2.6 Plan and Gamma Analysis of "Design No.44" From James Christie's Catalogue of New Zealand Homes [ca. 1910]. This plan conveys the typical structure of late eighteenth and early twentieth century Victorian Villas. It was these types of plans that were associated with poor living conditions, and that state houses were in response to. Despite this, the hallway clearly controls the access to all spaces in the house in a similar manner to state houses. 


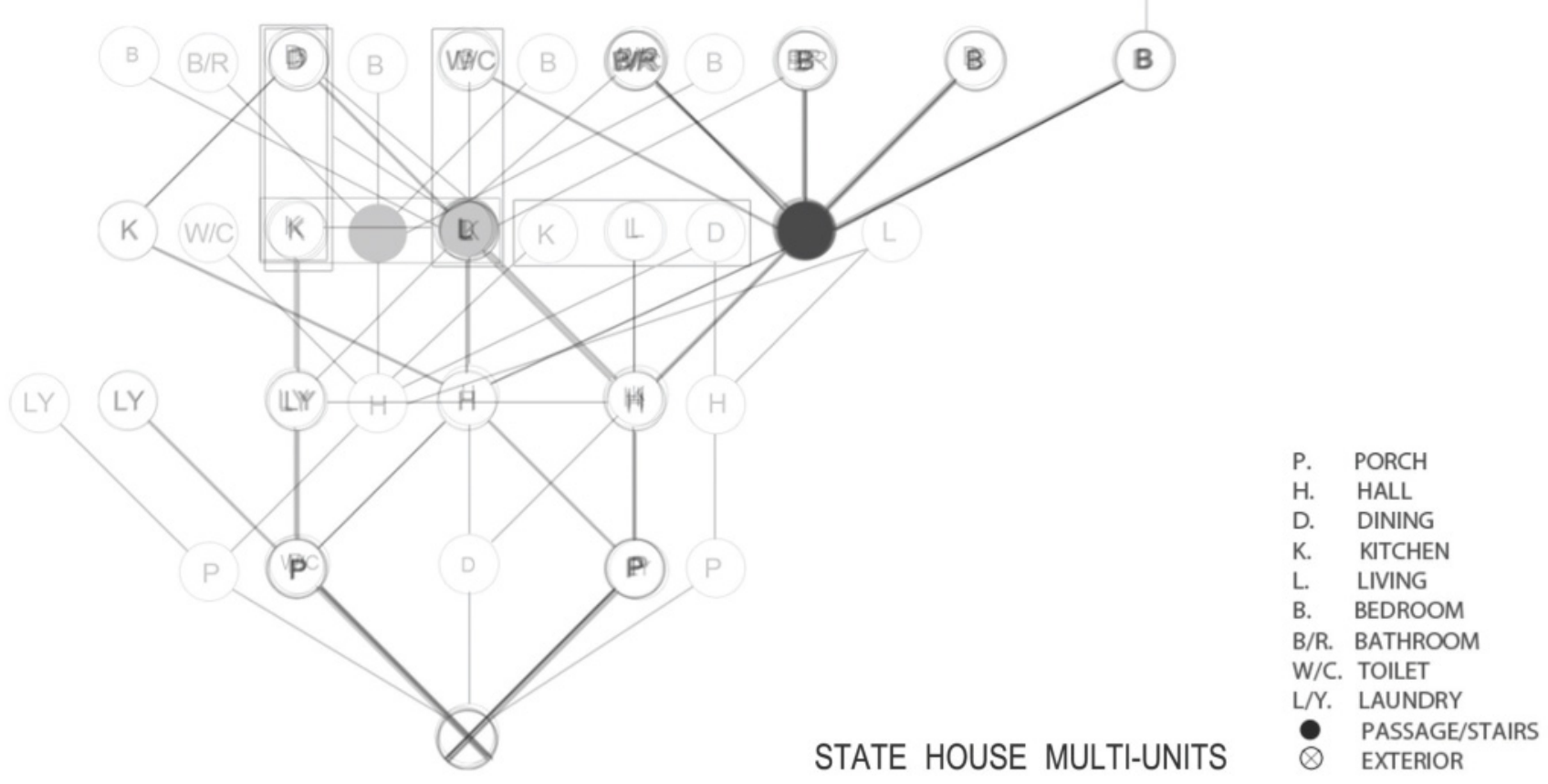

Figure 2.7 Gamma Analysis Overlays of State House Multi-units. These plans continued the structure seen in earlier state houses, but divided bedroom and living spaces by floor through stairs rather than a central hallway.

The typical State House was almost always timber framed on concrete foundations, and in 1949 "about 25 per cent of houses are finished externally in brickwork, 40 per cent with weatherboards, and 35 per cent with asbestos cement of two types, sheets and smaller units." ${ }^{48}$ Internal finishings were similarly standardised, with:

fibrous plaster or similar sheets finished with enamel paint in kitchens, bathrooms and W.C.s, and wallpaper in other rooms. Ceilings are painted. Windows are of casement and top hung "split rail" fanlight types. Chimneys are constructed of reinforced brickwork, or reinforced concrete, or pre-cast reinforced pumice concrete. Roofs are of clay or concrete tiles, corrugated asbestos cement sheets or bituminous fabric. ${ }^{49}$

This standardisation of style and parts extended right down to fixtures. ${ }^{50}$ While it was considered that such standardisation imposed "no undue limitation" on design, later critiques of state housing's "monotony of difference" suggest otherwise. Almost all State House designs under Labour (and later under National) abided by the conservative neo-Georgian English cottage style, characterised by gabled and hipped roofs with tight eaves, three-light casement windows and simple, clean detailing (Fig.2.11). ${ }^{51}$ This neo-Georgian English cottage aesthetic remained dominant from its beginnings right up until the mid-1970s; as Toomath put it "the mould was set for the typical New Zealand house for decades to come." 52

\section{Changing Attitudes: The National Government and State Housing Post-1949}

Following the National party's 1949 election win, Gordon Wilson and Reginald Hammond drew up two new State House plans for National that were in line with the desire to cut construction costs. ${ }^{53}$ Hammond's house, with its multi-unit space, "met with disapproving remarks" from mothers with whom "the Wilson design would have been a firm favourite", but architects argued "that those unaccustomed to 'open planning' would have to live in the Hammond house to appreciate the greater comfort and

50 Firth states that fixtures "such as sink bench units, cupboard units, safes, and hot-water cupboards are of one type and size for all detached houses ... In addition, of course, such items as baths, sinks, basins, coppers, and tubs are of standardized types and sizes. Standardization will be carried further when the local manufacture of hardware and other components increases." Firth, 40 51 Schrader, We Call it Home, 89, also Toomath, 173-175

52 Toomath, 174

53 This signalled the start of a new era for state housing in New Zealand which saw a promotion of home ownership, a concentration on the quantity of houses built rather than the quality, a cutting of material, design and community infrastructure standards to reduce costs, and a shift from state housing being a programme aimed at the middle class to a programme utilised as a form of welfare provision for the lower classes. Wilson's plan cut costs by removing the entrance hall, allowing the living room and kitchen to expand, and by using a lighter roof, fibreboard ceilings, cheaper wallpaper and top-hung windows (which required less timber). Hammond also utilised cheaper materials, and introduced a more open plan, making the living-dining-kitchen areas as a single space. Hammond's plan also contained a curtained-off children's bedroom that could be opened each morning to form a spacious playing area, making his plan the greatest departure from the State House model of the two. Schrader, We Call it Home, $41-44$, $107,213-214$ 


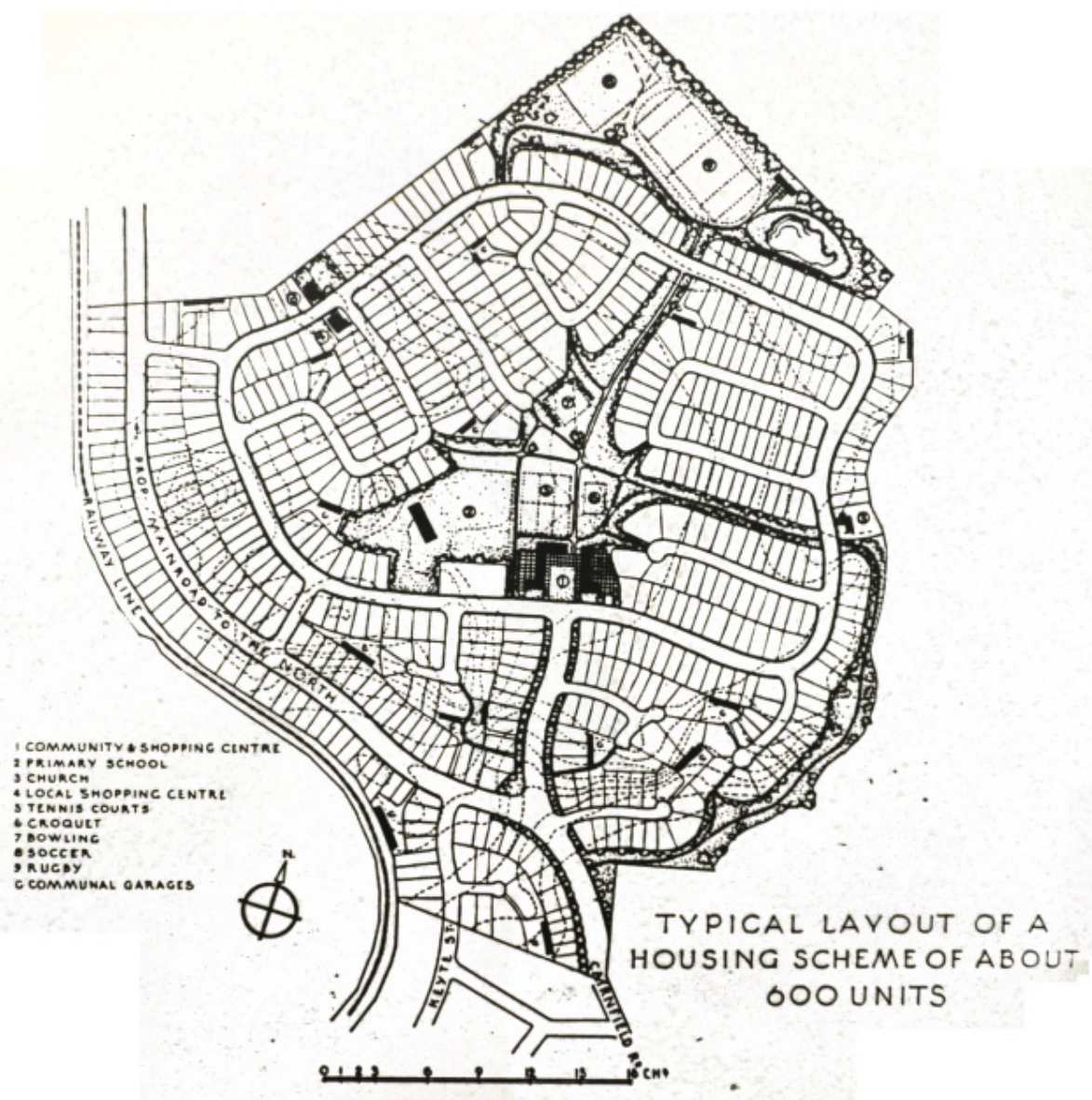

Figure 2.8 Typical Layout of a State Housing Scheme of about 600 units. The plan arranges curving and cul-de-sac roads around a central area containing a community and shopping centre, school, church, and recreation facilities. House sections were sized to fit detached houses for nuclear families. State House developments after 1949 kept the suburban structure, and were able to more clearly realise it due to the arrival of heavy earth moving equipment that allowed cut and fill development, but did not provide the same level of recreation and community facilities depicted in this plan.

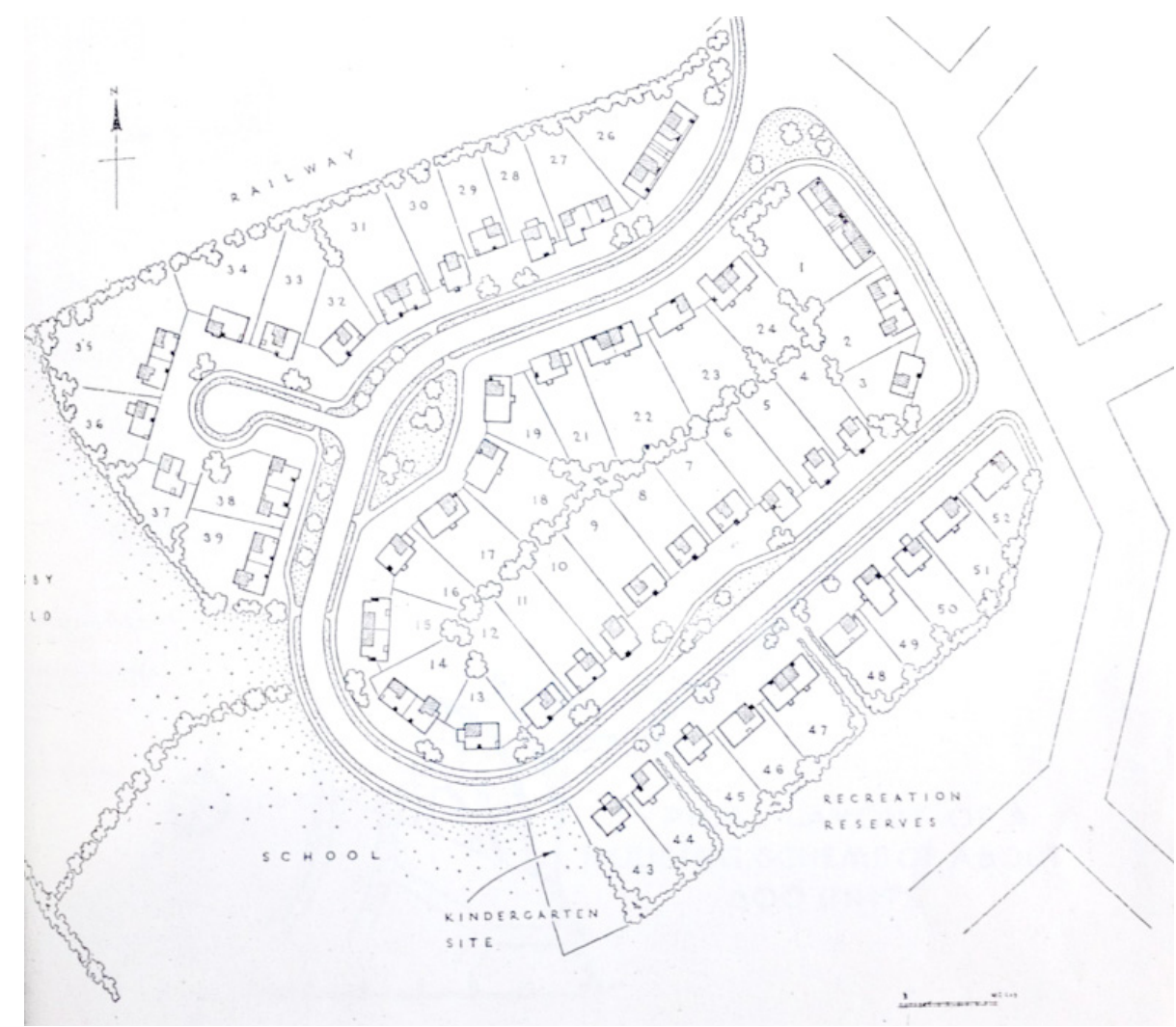

Figure 2.9 Typical Site Plan of a State House Cul-de-sac Development. This plan, from 1949, shows the integration of multi-unit dwellings that was beginning to occur in state house developments at this time. The darker areas within the house footprints show the location of living rooms. 


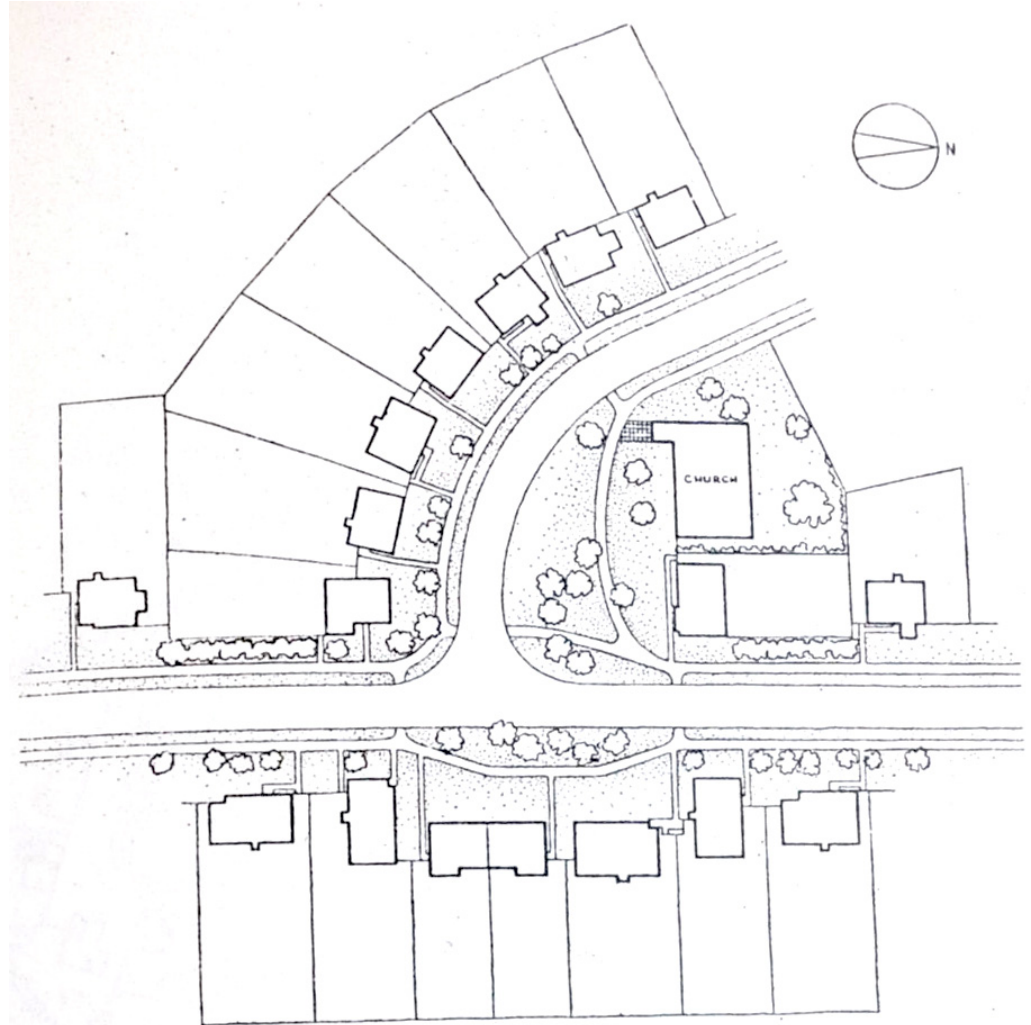

Figure 2.10 Site Plan of Typical Road Intersection Within State House Developments. This plan conveys the section structure common in state house developments, with houses sited at the front of each section, facing the street, leaving a back yard space at the rear of the section. All the houses are of a similar size, conveying the autonomous provision of houses for the nuclear family.

Figure 2.11 State House Front Elevation Overlays. These images were constructed through overlaying front elevations of various detached state houses. The images were aligned to the front door, resulting in that becoming the most prominent feature. The images convey the standardised form of state houses, with a slightly recessed front door, simple and tightly eaved roof, and three bay windows. 
spaciousness it had to offer." ${ }^{54}$ However, archival evidence of State House plans suggests that any transformation was limited to the replacement of the formal dining room with a dining space usually located in the kitchen ${ }^{55}$, and the division between the kitchen and living sometimes being achieved through a partition wall or kitchenette rather than a full floor to ceiling wall (Fig.2.12-2.17). ${ }^{56}$ In essence, from 1937 to the 1970s, the socio-spatial systems in state housing remained fairly constant, with private bedrooms remaining clearly demarcated from family spaces. The hallway remained as the central controlling space, and the more unconventional elements seen in Hammond's design did not feature, suggesting they were seen as too much of a departure from the conventional State House plan.

The developments of the 1950s and 1960s saw the increased use of multi-unit dwellings as a response to growing concerns over urban sprawl and a need to limit construction costs. ${ }^{57}$ In 1957 National introduced a policy which required 25\% (later 50\%) of new State Houses to be multi-unit, and these were built in large numbers in large scale state housing developments of the 1950s and 1960s, such as Porirua, Mangere, and Otara (Fig.2.18)..$^{58}$

These larger scale developments, made possible by the arrival of heavy earth-moving machinery and cutand-fill land development, ${ }^{59}$ took the place of the smaller suburb-scaled schemes enacted under Labour. ${ }^{60}$ A typical example is Porirua, north of Wellington city (Fig.2.19-2.22). Envisaged as a new city of 70,000 people, the construction of Porirua began in 1948 and continued throughout the 1950s and 1960s, when the initial population estimate was revised downwards. ${ }^{61}$ Sites set aside for private dwellings were taken over by the state to keep up with growing demand, resulting in Porirua becoming the largest single state housing community in the country. ${ }^{62}$

By the end of the 1960s the National government's changes were in full effect. ${ }^{63}$ Over the next twenty years criticism of the new direction of State House developments accumulated, ${ }^{64}$ and in 1971, a Commission of Inquiry into housing criticised the government for the developments seen in Porirua and Otara and recommended that such developments cease. ${ }^{65}$ Despite some of the worst quality multi-units being demolished in the 1980s and 1990s, areas such as Eastern Porirua remain largely unchanged to this day and continue to experience negative socio-economic and built environment quality issues. ${ }^{66}$

54 Building Progress, 1953, 3, 8, see also Wilson and Hammond, 8, and Wilson, 28

55 Firth attributes this change to the results of a tenant survey that showed that the "general preference lay in taking meals in the kitchen" which was originally "regarded by planners not as an eating place but as a workroom". Firth, 31-32

56 Housing Corporation of New Zealand, Head Office [agency code AALF], "Photographs of State Housing Plans"

57 Multi-units were forms of terrace housing containing two to six dwellings, with living, kitchen, and dining areas located on the ground floor with bedrooms above. Interestingly, however, the cost of constructing multi-unit dwellings was actually higher than single detached houses. Schrader, We Call it Home, 109-111, also Ferguson, 188

58 The preference for multi-unit housing rather than duplex or apartments was perhaps a reflection of the continued preference for suburban-type dwellings and planning. One of the primary campaign points of the first National Government in particular, was to make home ownership a real possibility for all New Zealanders, for whom (in the eyes of the government) home was a suburban house, not an apartment in the city. Therefore the multi-unit, detailed as it was to represent the suburban detached house, would have been a natural choice as apartments were anathema to the vision of home ownership National had promised. As Firth himself said "in a country such as New Zealand where the detached house is the ideal, any excursion into the erection of apartment blocks demands an excuse, even an apology." Firth, 33, see also Schrader, We Call it Home, 40-47, 36-37, Schrader, "Labour at Home", 125-139, Isaac and Olssen, 107-124, Ferguson, 195

59 This process saw the ridges of hills removed and used to fill valleys, creating a softly rolling landscape that was ideal for suburban development. This meant that the government could fit more houses within the same square area, and that areas that had rendered development difficult or impossible previously could now be flattened and developed. Ferguson, 200

60 Schrader, We Call it Home, 180-182

61 Schrader, We Call it Home, 181, also Ferguson, 200

62 Schrader, We Call it Home, 181

63 Schrader, We Call it Home, 213-215

64 In 1963 the Anglican Church criticised the suburban development in Porirua East for providing a lack of public amenities (its first was a tavern), lack of consultation with residents, and its creation out of nothing in a very short period of time. In short the church argued that "the government has laid out an impressive paper plan for a housing area, but it ... has done nothing to make Porirua a community." In the same year a letter from the Commissioner of Works, J.T.Gilkison, to the Minister of Housing pondered if the "urban sprawl aspect has been over-emphasised" in housing policy, and commented that perhaps more single dwellings should be built in light of the higher cost and unpopularity of multi-units. A few years later, the New Zealand Institute of Architects expressed concern over the concentration of low-income families into 'desert-like' areas lacking employment opportunities, easy access to high quality public transport, and government involvement in providing supporting amenities such as play centres, kindergartens and a community hall. Schrader, We Call it Home, 213-217

65 Schrader, We Call it Home, 224

66 For example, the 2011 Inside New Zealand documentary Inside Child Poverty: A Special Report, followed the six month journey of Bryan Bruce as he investigated the reasons behind New Zealand's $28^{\text {th }}$ out of 30 ranking for child wellbeing in the O.E.C.D. Bruce begins his journey in Porirua East, which he states has the highest rate of rheumatic fever in the country, a 'disease of poverty'. In the documentary the contribution of the built environment, in particular its housing, to the problem is palpable, with Bruce being shown through damp, overcrowded houses with mouldy ceilings and walls. "Inside New Zealand: Inside Child Poverty: A Special Report" 


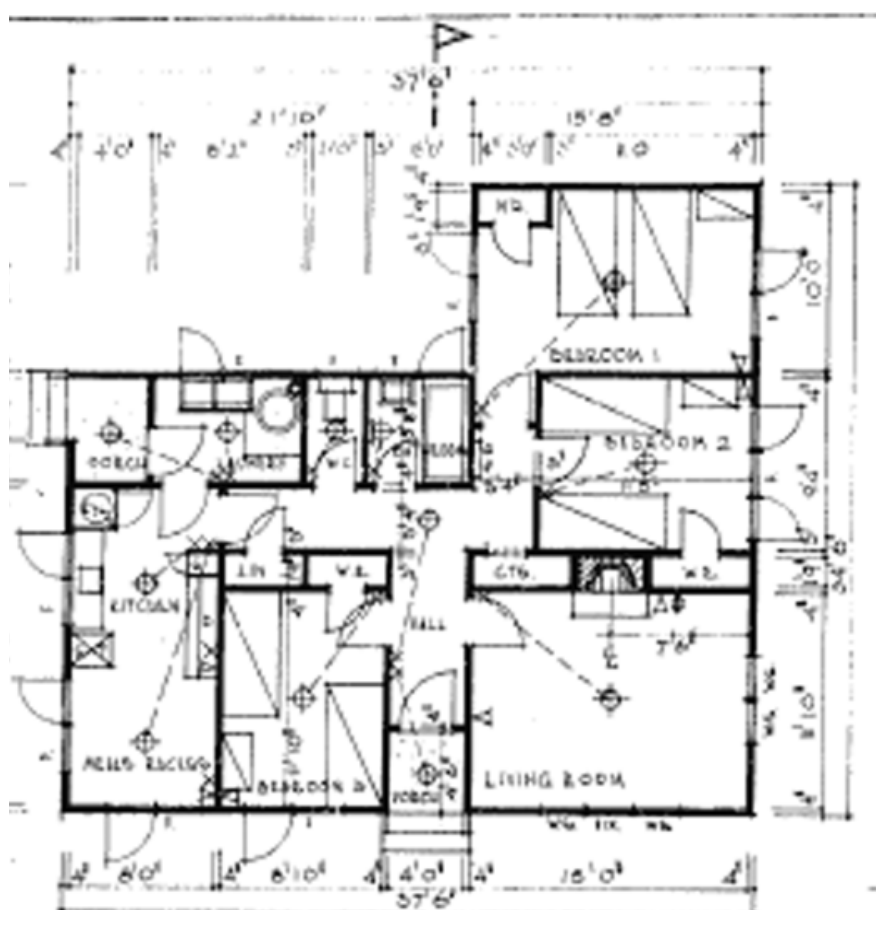

Figure 2.12 State House Plan used within the Development of Block 7b, Cannons Creek, Porirua [ca. 1960-1965]. This plan, still in use in the 1960s, confirms the standardisation of state house plans throughout most of the twentieth century. The hallway still clearly demarcates the boundary between spaces, and the plan stands in contrast to some of the modernist influenced plans architects were exploring in New Zealand at this time.

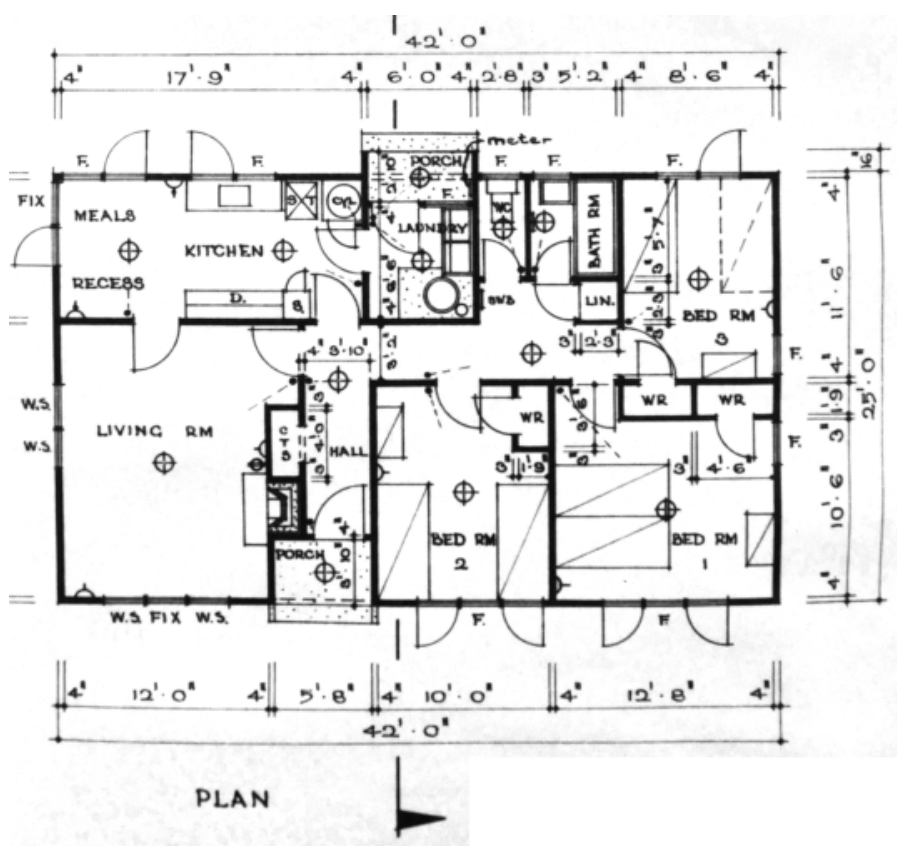

Figure 2.14 State House Plan No. W6/156/S1 used within the Development of Two Homes using New Experimental Construction Methods in Porirua [ca. 1962]. This house utilised new construction materials and methods such as load-bearing precast concrete panels, rain-water drainage and sewage pipes, and poly-vinyl-chloride fittings. Despite this, the plan remained conventional, with the only difference to a traditional state house plan being the provision of a doorway between the kitchen and living room.

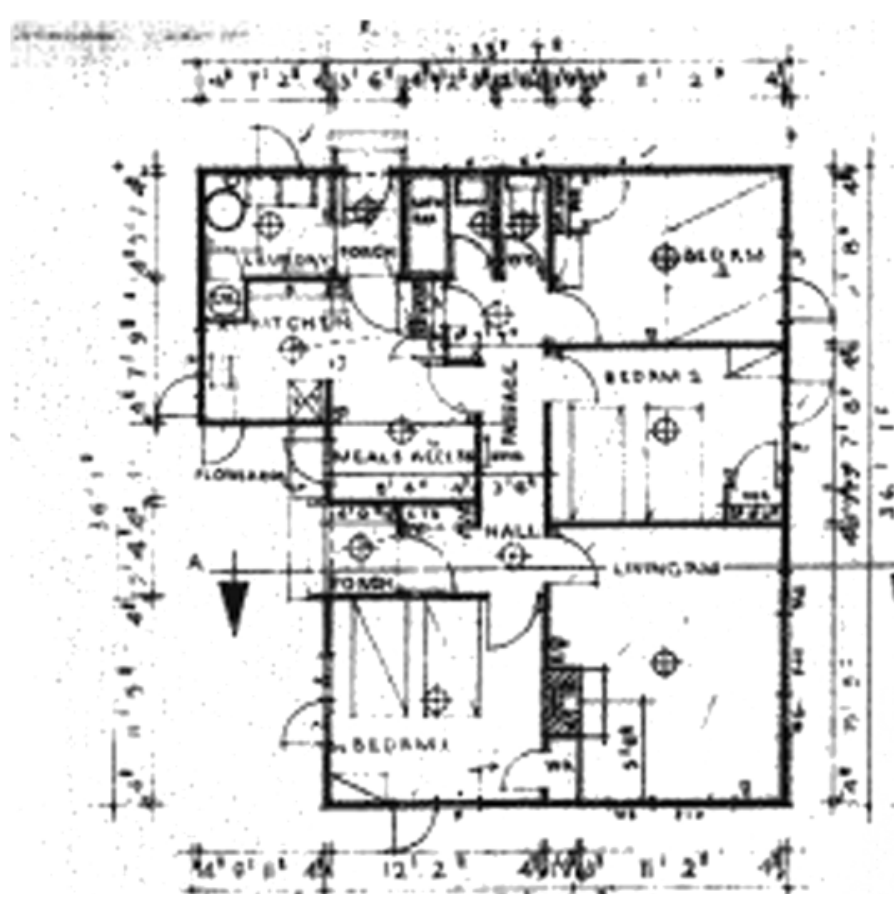

Figure 2.13 State House Plan used within the State House Development of Block 7b, Cannons Creek, Porirua [ca. 1960-1965]. This plan displays some of the changes that became more prominent in state housing after 1949, such as the entrance to one bedroom leading of the lounge. However, like the plan depicted in the previous figure, its underlying spatial structure is almost identical to earlier state houses.

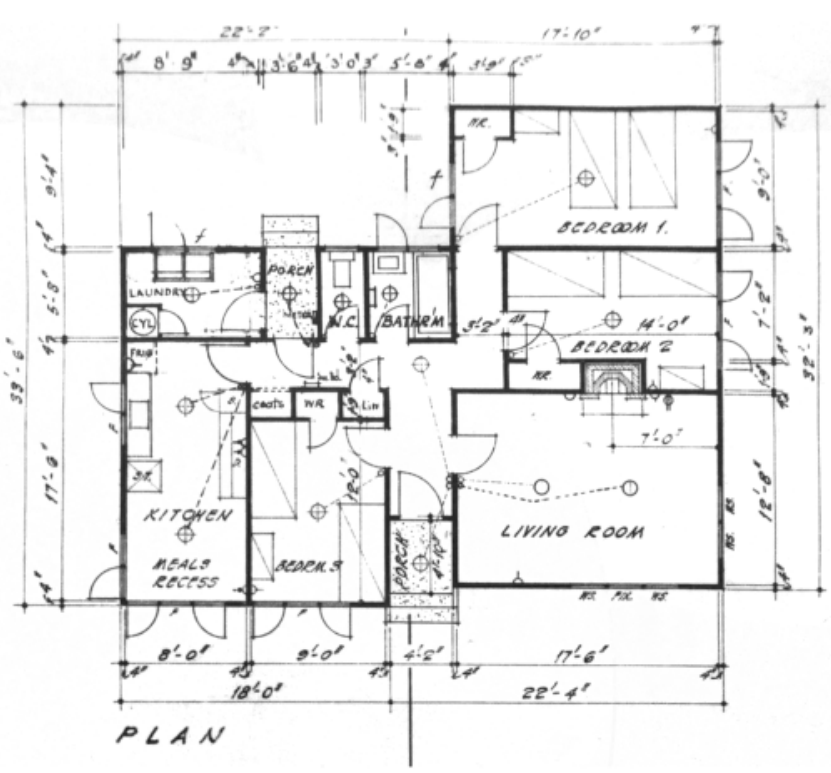

Figure 2.15 State House Plan No. W6/276/S1 used within the Development of Two Homes using New Experimental Construction Methods in Porirua [ca.1962]. Like the house in the previous figure, this house conveys a very traditional state house plan despite it being an 'experimental' house. It seems that the Department of Housing Construction, whilst willing to experiment with new construction methods and materials, was limited in its experimentation of spatial planning. 


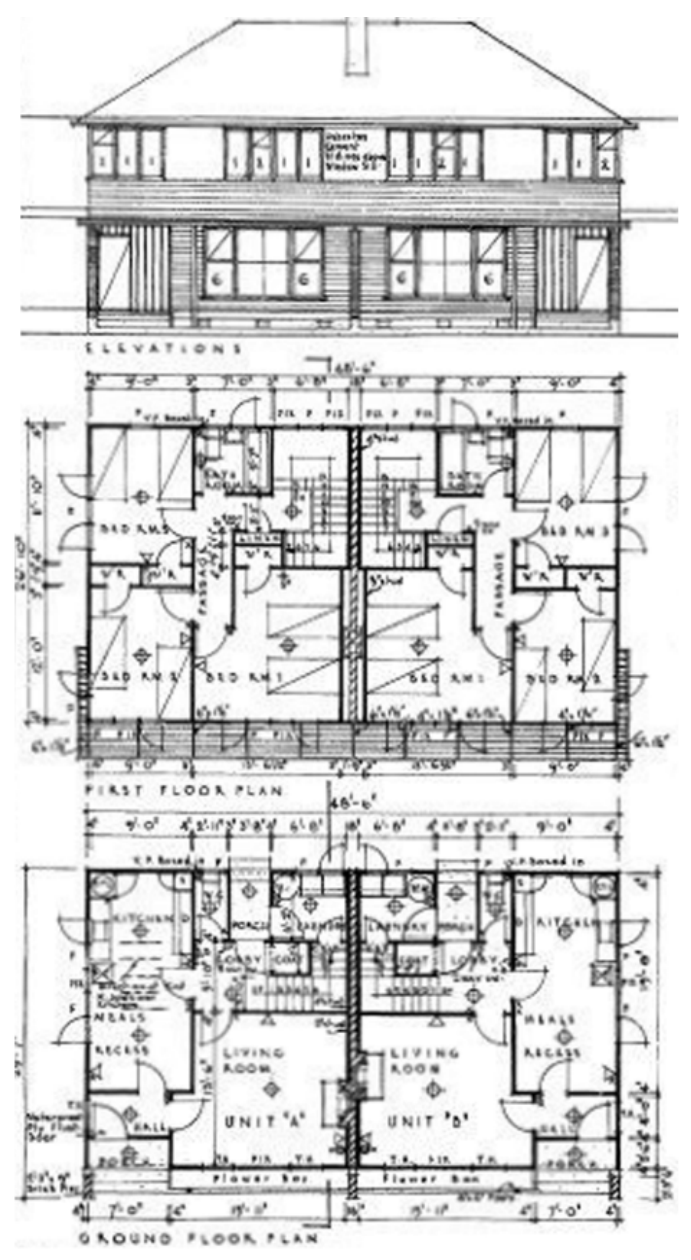

Figure 2.16 State House Multi-unit Plan used within the State House Development of Block 7b, Cannons Creek, Porirua [ca. 1960-1965]. This plan shows the departure from the typical state house spatial structure sometimes forced in multi-units due to the limited space available. This house has a front entrance alcove which opens not into the central hall/corridor, but directly into the lounge and dining areas. A hallway was however still provided at the rear section of the ground floor and on the first floor.

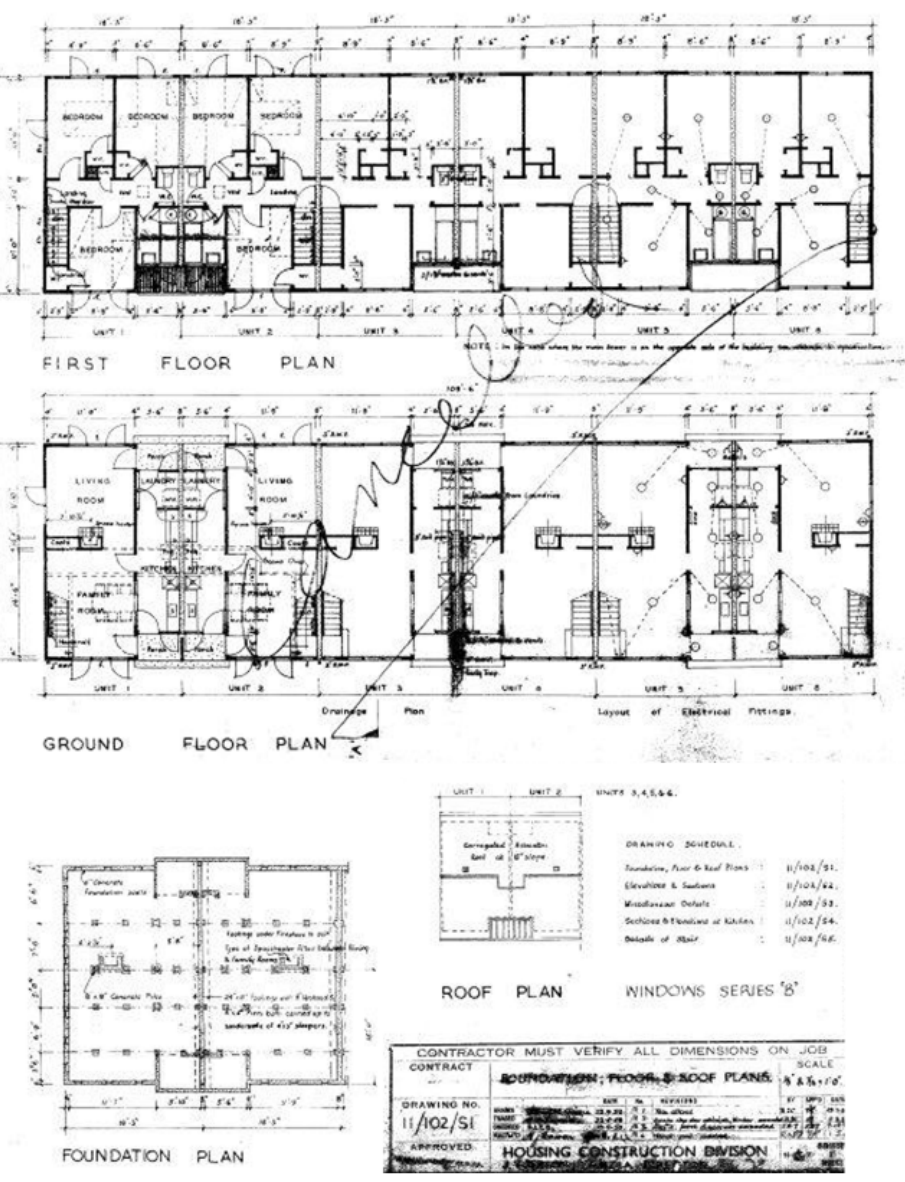

Figure 2.17 State House Multi-unit Plan used within the State House Development of Block 7b, Cannons Creek, Porirua [ca.1960-1965] This six unit block is similar to the previous figure in that it provides an entrance directly into living areas rather than a central hallway. However interestingly, the dimension and arrangement of the kitchen with other spaces results in the kitchen becoming a hallway space. Also of note is the provision of a 'family room' as well as the common living room, complete with dining table, conveying a return to a formal dining space seen in earlier twentieth century New Zealand homes.

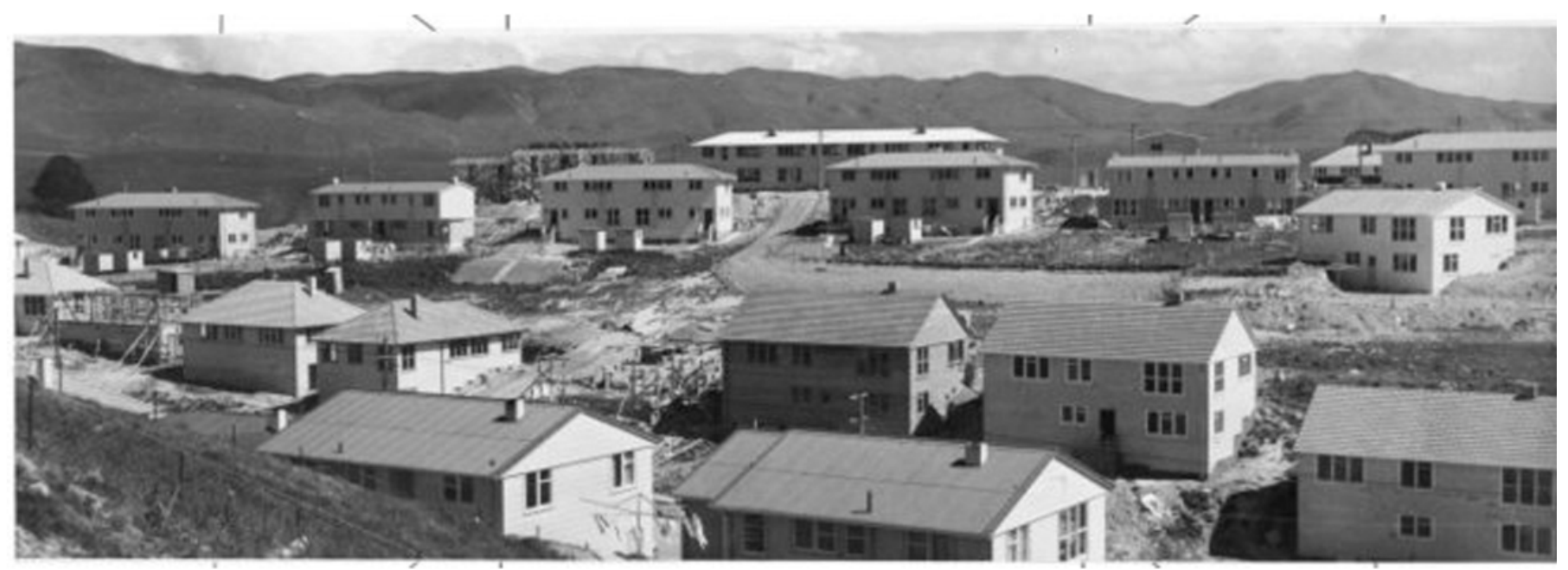

Figure 2.18 State Housing in Porirua East. This photograph conveys the prevalence of multi-unit dwellings within the development of Eastern Porirua. 


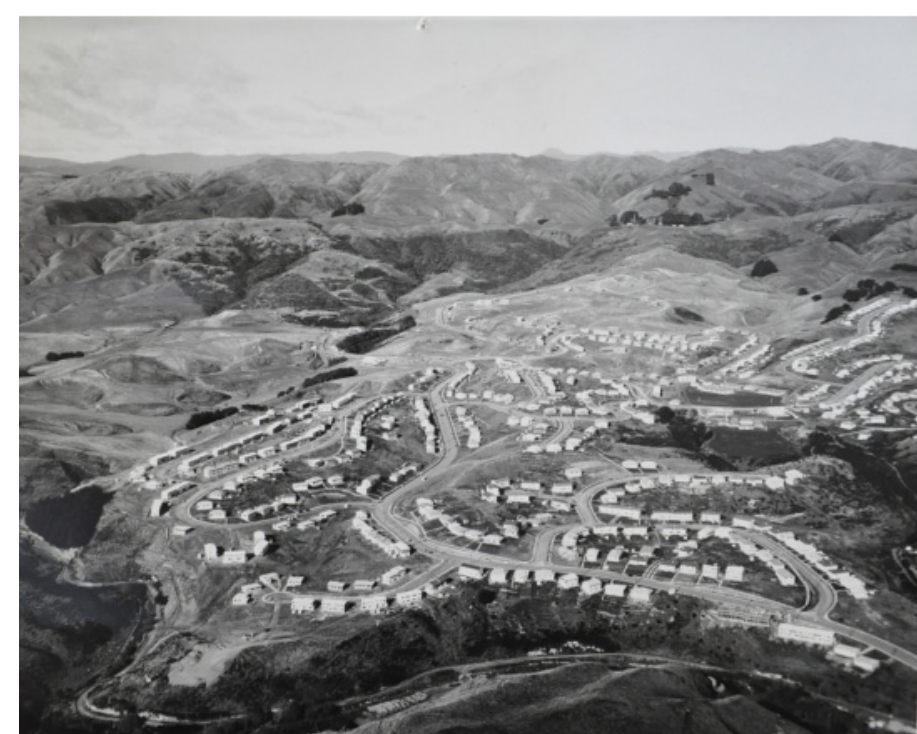

Figure 2.19 Porirua East Development [ca. July 1960]. This aerial photograph shows the realisation of the typical suburban structure of Firth's state house layouts. Within the image you can see the land has been left scoured after being subject to cut and fill development.

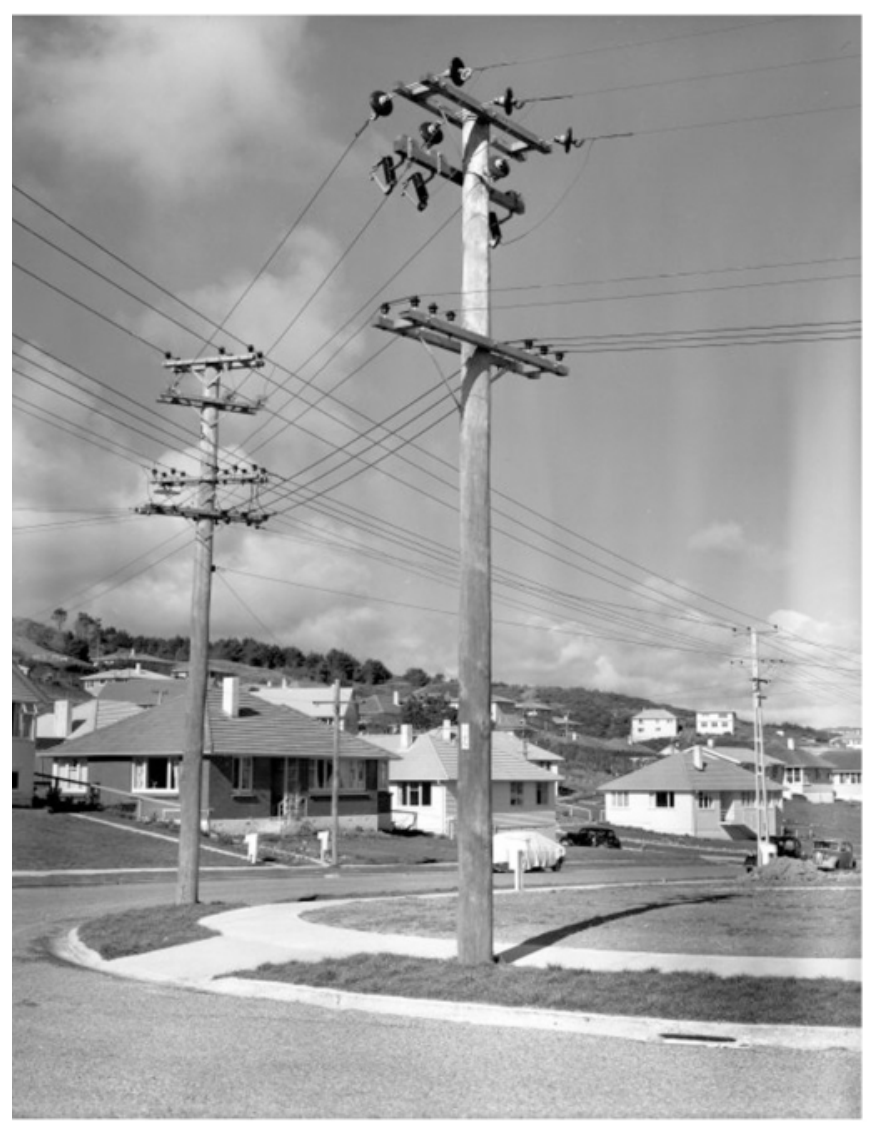

Figure 2.21 Suburban Street, with Power Poles, Porirua, Wellington. This photograph by Duncan Winder conveys the typical suburban landscape of Eastern Porirua, with similar houses plotted on similar sections in an autonomous pattern.

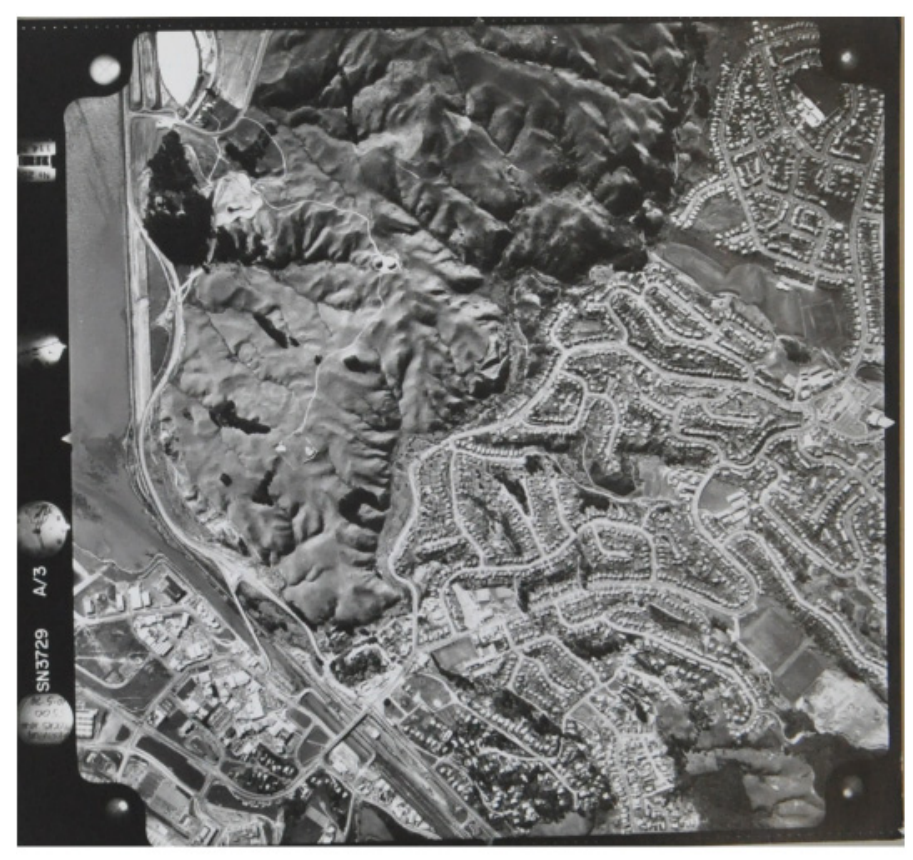

Figure 2.20 Untitled aerial image of Porirua [ca: 1965]. This image, taken approximately five years after the previous figure, shows the spreading of the suburbs in the top right of the image, and the relation of the suburbs to State Highway 1 and the Porirua City Centre, that was development during the 1960s, on the bottom right of the image.

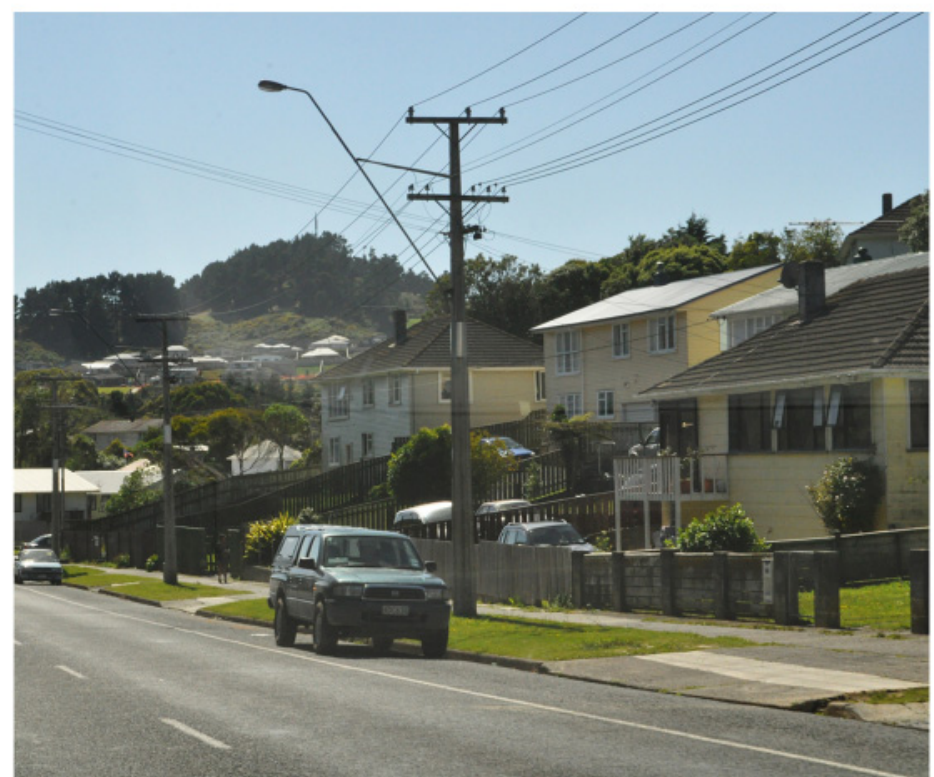

Figure 2.22 Untitled Photograph of State Houses Within Porirua East. This photograph conveys the typical situation within contemporary Eastern Porirua, with state house sections now often being fenced off from the street. 


\section{Section Two: An Analysis of the Twentieth Century New Zealand State House}

The previous section introduced the historical development and architecture of the New Zealand State House. This section analyses the State House as an instrument of colonial power, and discusses the effect the State House had on the development of New Zealand's architectural and social identities.

\section{The Politics of Representation: The State House, colonial mechanisms of representation, and functionalist suburban and architectural design}

In Boundary Markers, Byrnes argues that colonial land surveyors not only physically colonised the land but possessed it through conceptual, textual, and visual strategies. ${ }^{67}$ Material, and aesthetic, gazes constructed a cultural space through particular methods of representation. ${ }^{68}$ The material gaze translated the unknown and subjective into universally known and objective terms, "lines, angles and distances, mediated through the theodolite and compass, formed the mathematical matrix through which surveyors constructed cultural space." ${ }^{69}$ This matrix transformed the land into a landscape of objective characteristics and measurements which legitimised and facilitated inhabitation. On the other hand the aesthetic gaze, enacted through the mechanisms of the panoptic and the picturesque, aided colonisation by instituting an alternative reality or cultural landscape that legitimised occupation and appropriation. ${ }^{70}$

Images documenting the development of state housing in Eastern Porirua can be read in these terms. Aerial photography charted the landscape (Fig.2.23-2.24) along with large line drawings which mapped and dissected the land into cities, suburbs, streets and housing sections (Fig.2.25-2.31). Suburban plans of the development present the land as flat and characterless, aside from the lines that demarcate abstract site boundaries and road markings, and letters which identify one block from another. In this way the land is translated to into codified and objective terms of lines, angles, and distances, in a manner that is focused upon and legitimises the future appropriation and inhabitation of the land.

Panoptic and picturesque images were also commonly used to represent the development of the landscape in Porirua. Some images present frames of boundless, empty landscapes prior to the construction of State Houses (Fig.2.32-2.33). Other images document the landscapes left flat and scoured from heavy earthmoving equipment (Fig.2.34). These images appear empty and desolate, and are only identifiable by the pencil titles occasionally written on the back of the photographs (Fig.2.35). They shatter the form and coherence of the land, and render Porirua as placeless. They create an alternative reality of boundless landscapes awaiting development, therefore legitimising appropriation and inhabitation.

This discourse extended beyond the urban scale into the architectural planning of State Houses. ${ }^{71}$ Archived State House plans are presented as interchangeable, easy to compare, and site-less, and are identified by a letter and number system (Fig.2.36). ${ }^{72}$ In this way the designs became site-less, objective and codified commodities, in much the same way as the landscape. The underlying socio-spatial structure, based on the nuclear family, of different plans followed the same pattern, which was repeated time and time again.

Preceding images document the filling in of this new identity, first with roads and then with groups of housing, in much the same way that the colonial bird's-eye image "created a vision of the future where the space designed for development was clearly marked and progress towards filling this space could be followed through the publication of revised birds eye views at regular intervals" (Fig.2.37-2.38). ${ }^{73}$

67 Byrnes argues that the "Transformation of the external world represented a personal and subjective adaptation: that the surveyor's remodelling of the external landscape was an attempt to address a sense of cultural dislocation and allow domestication of the land to occur." Byrnes, 6-8

68 Byrnes, 39-46

69 Byrnes, 50

70 Byrnes, 39-40, 62, 76

71 Firth, 14-33

72 The catalogue system assigned a letter for the type of house (two bedroom, three bedroom, multi-unit etc.), and a number for the particular plan type.

73 Byrnes, 63 

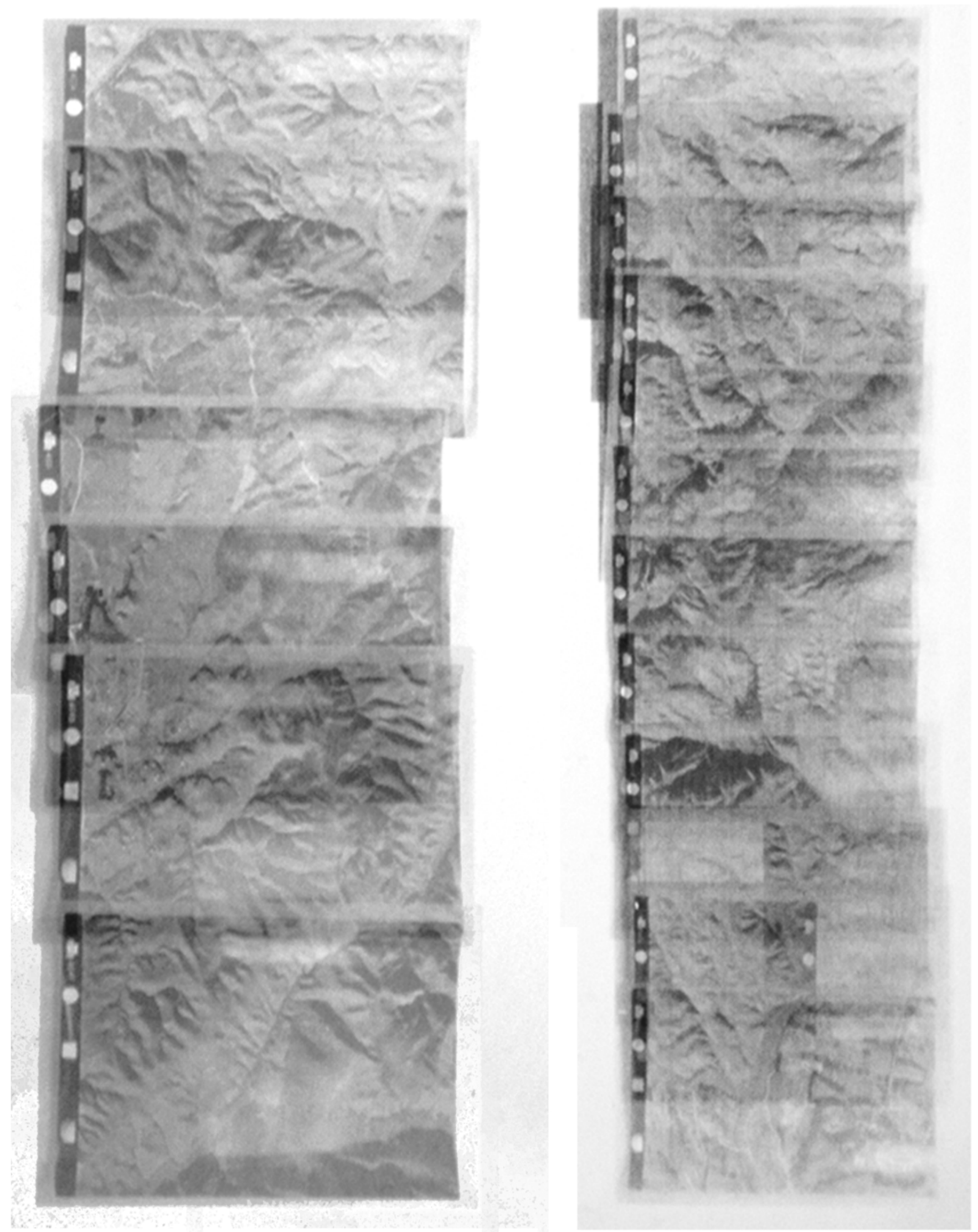

Figure 2.23 Overlays of Aerial Photographic Images of Porirua 1. These images show the charting of what appears to be a boundless landscape awaiting appropriation. 

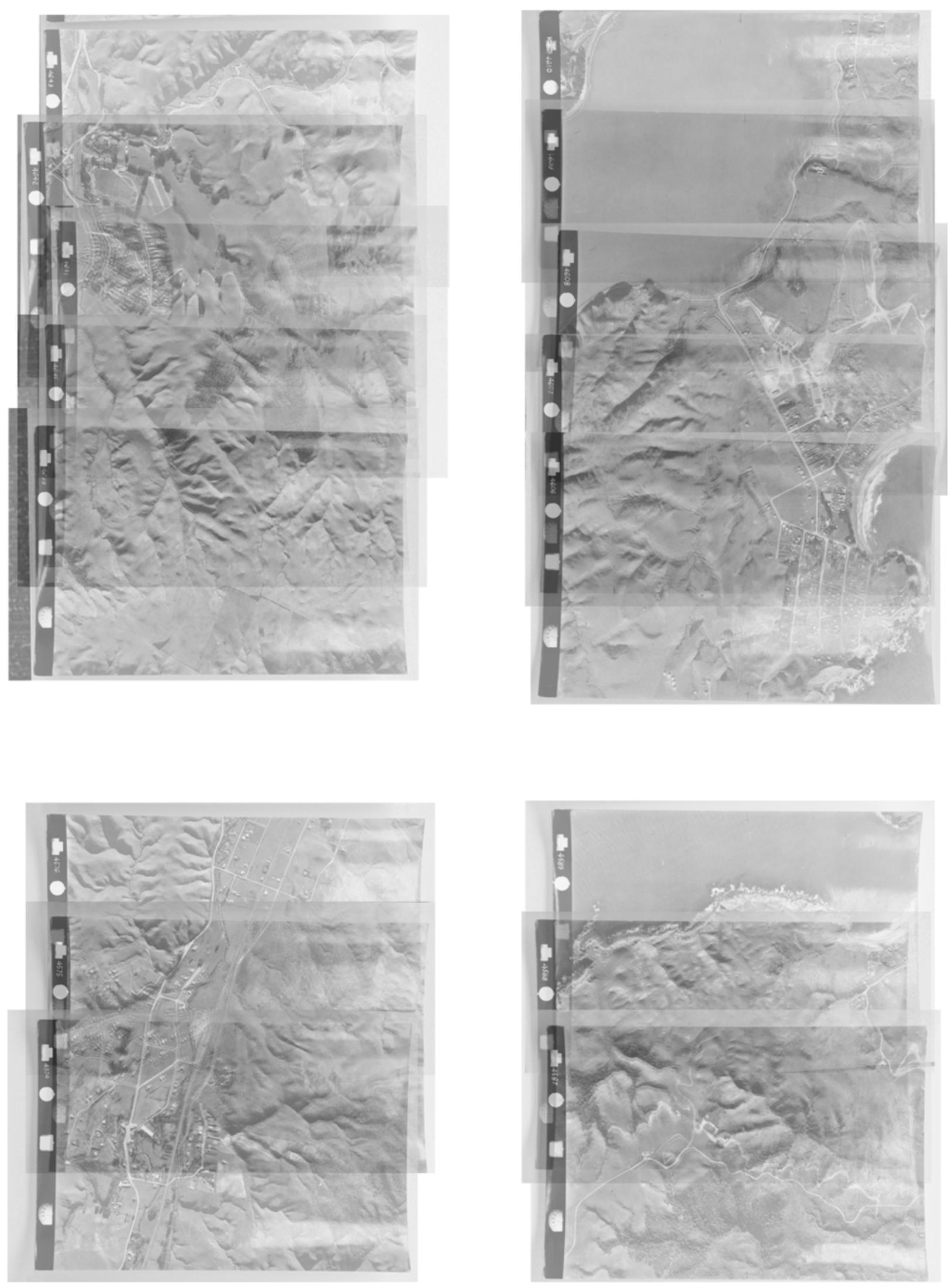

Figure 2.24 Overlays of Aerial Photographic Images of Porirua 2. These images show the charting of what appears to be a boundless landscape awaiting appropriation, as well as the 'filling in' of the landscape already occurring. 

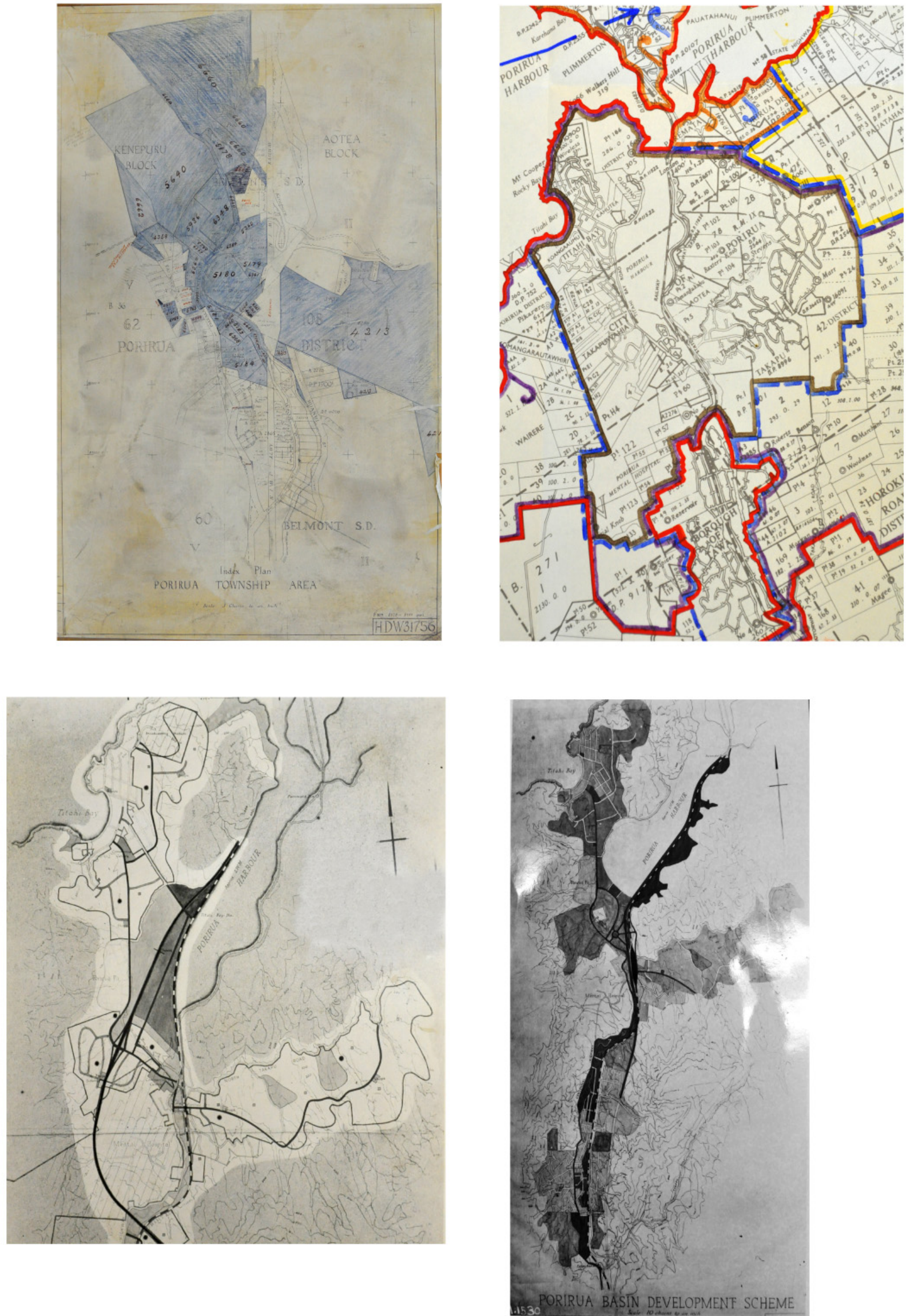

Figures 2.25-2.28 Various Maps of Development Plans of Porirua. These maps convey the discourse of writing over and codifying the land in mathematical and economic terms. The bottom two images focus on roading and transport through the area, confirming the focus on occupying the land. The images render the land as flat, removing the hilly identity presented in the previous aerial photographs documenting the land. 


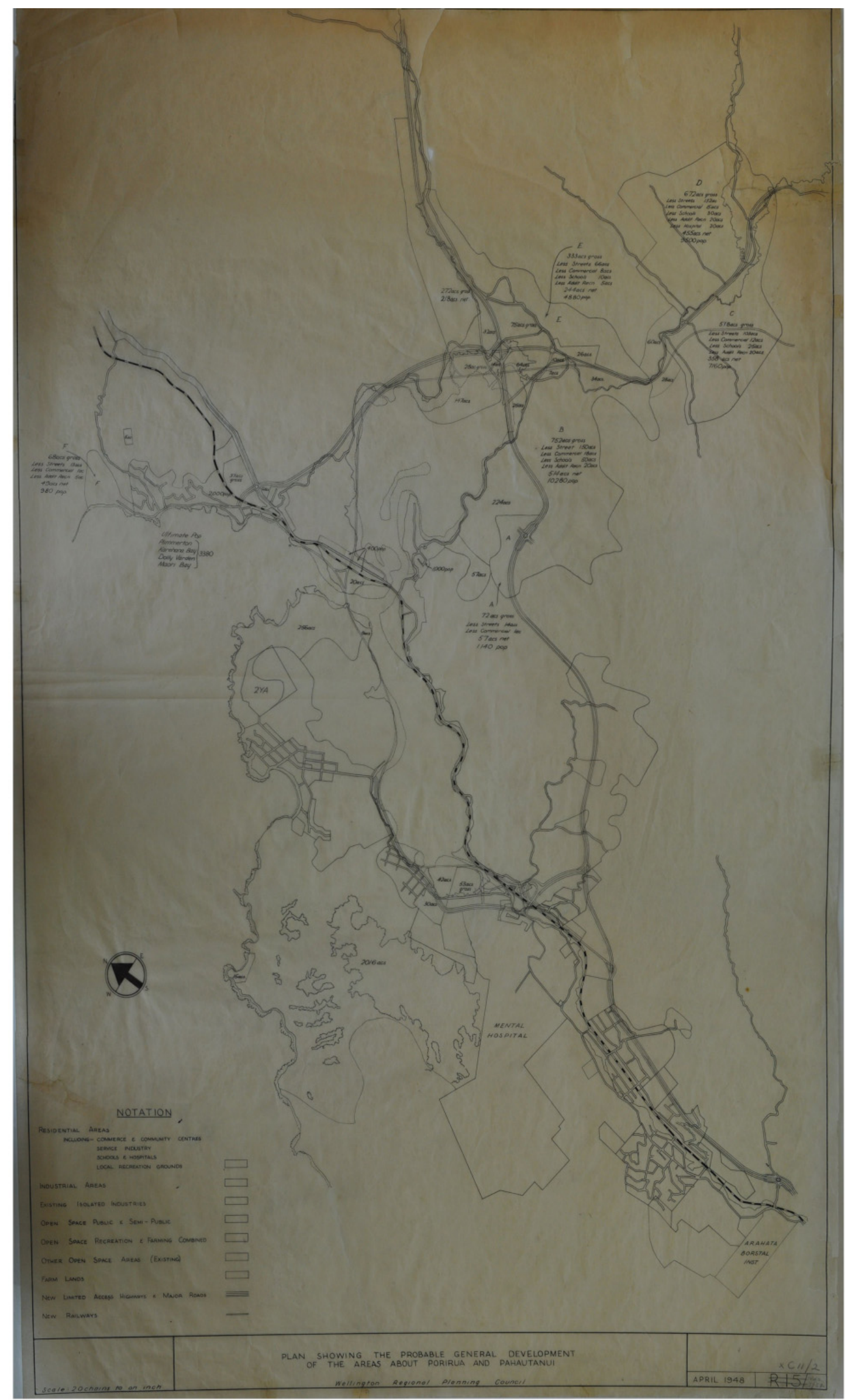

Figure 2.29 Plan Showing the Probable General Development of the Areas About Porirua and Pahautanui [1]. Like the figures on the previous page, this image conveys the focus on occupying the land, focusing on the methods of movement and transportation across it. 


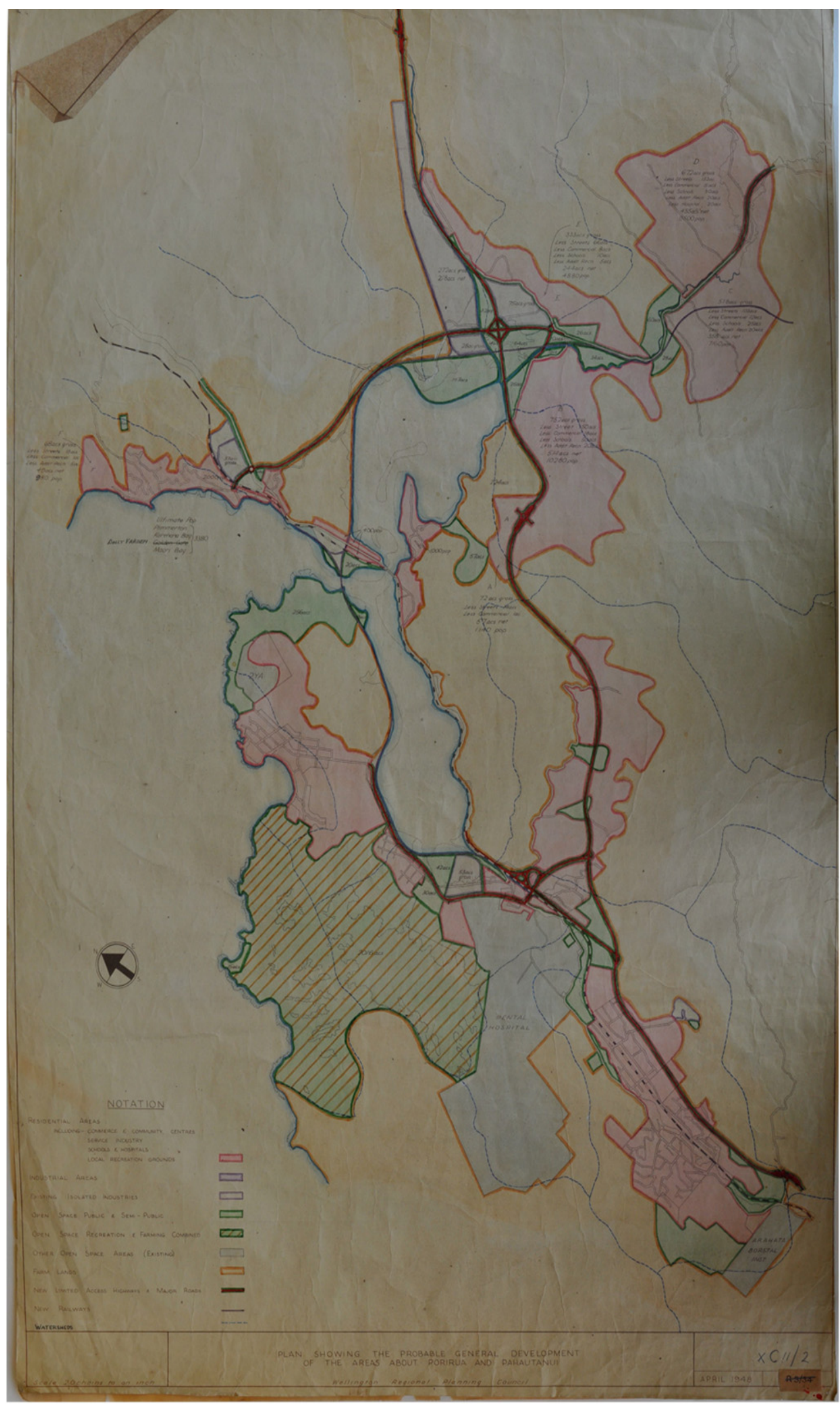

Figure 2.30 Plan Showing the Probable General Development of the Areas About Porirua and Pahautanui [2]. This plan conveys the sectioning of the land for economic production. The different colours stand for Residential Areas (Pink), Industrial Areas (Purple), Farm Lands (Orange), Open Space and Recreation and Farming combined (Various Greens), Highways and Major Roads (Red with Green Trim), Railways (Purple line), and Watersheds (Dotted Blue line) 


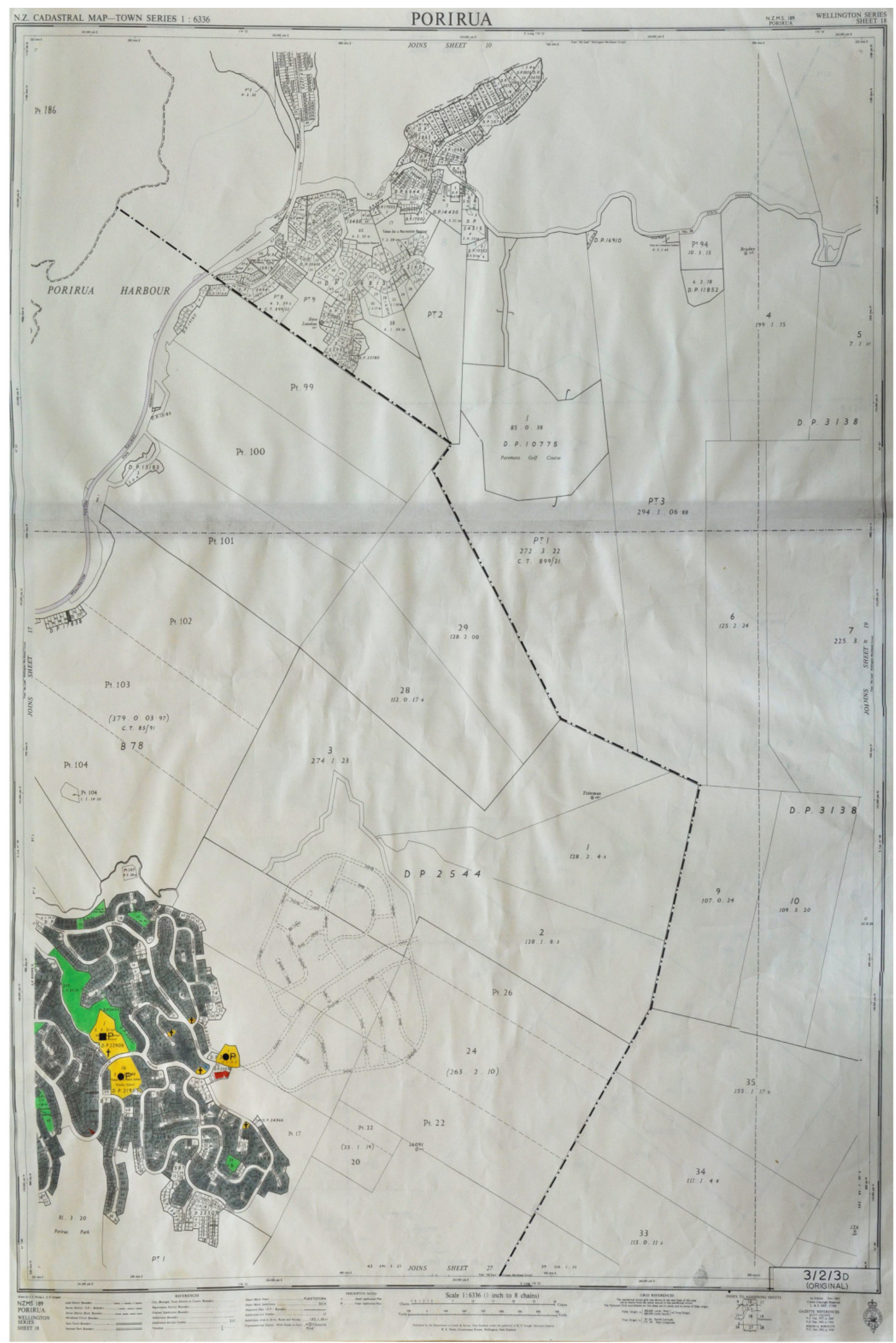

Figure 2.31 Planning Data Map "Porirua No.3/2/3D" - Porirua Borough as at November 1963. This map conveys the filling in of the landscape with state housing developments, with completed developments coloured in with grey, yellow and green in the lower left of the map, and the current development of Block 7b, Cannons Creek, being pencilled in on the maps lower centre. 

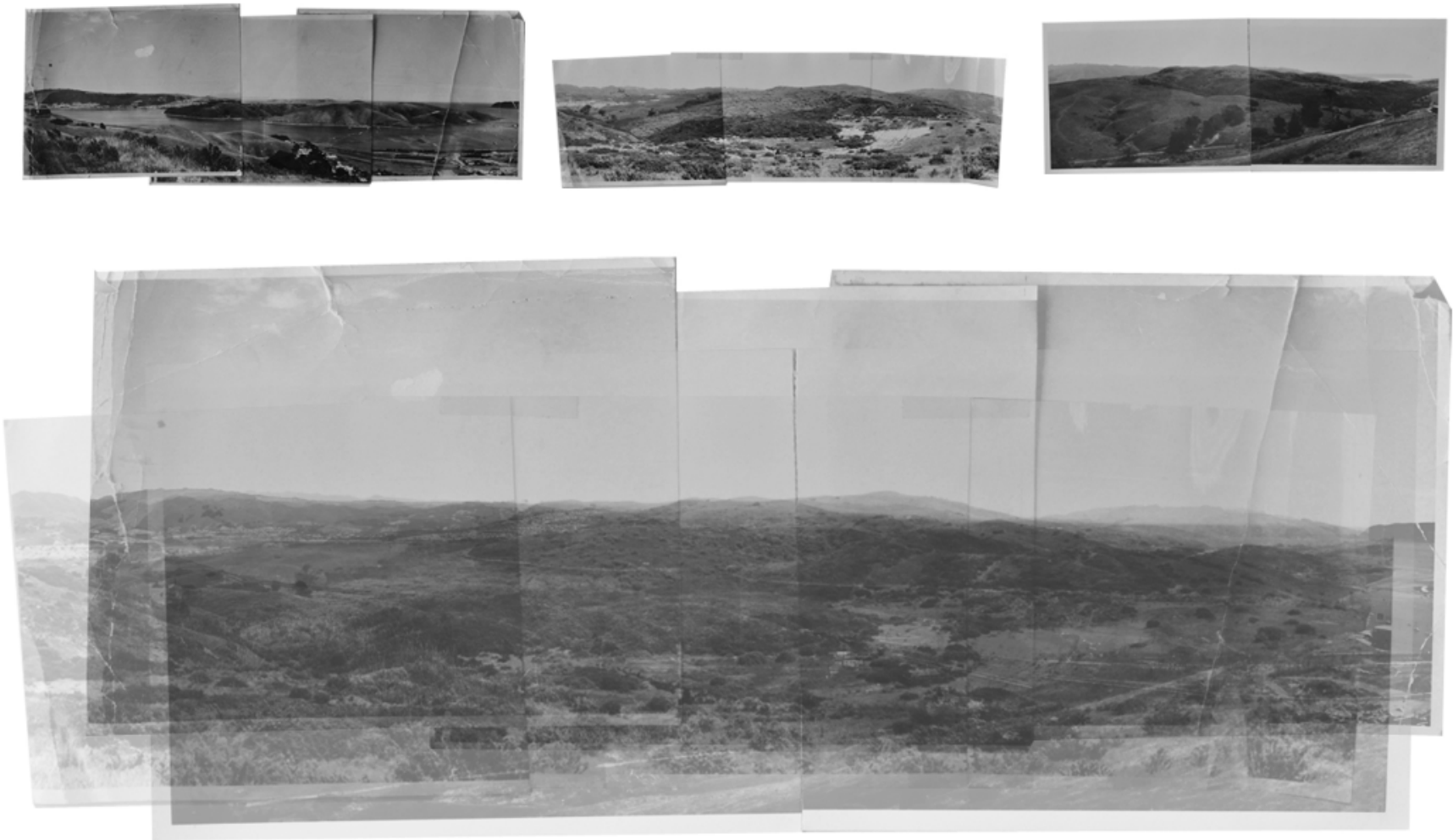

Figure 2.32 Porirua Landscape Overlay Image 1. These images, like the earlier aerial photographs of the landscape, construct a boundless landscape awaiting appropriation. Individual photographs were ripped and taped together by hand to create panoramic and panoptic representations of the land. By overlaying the individual images, the recurring narrative of the photographs becomes clear.
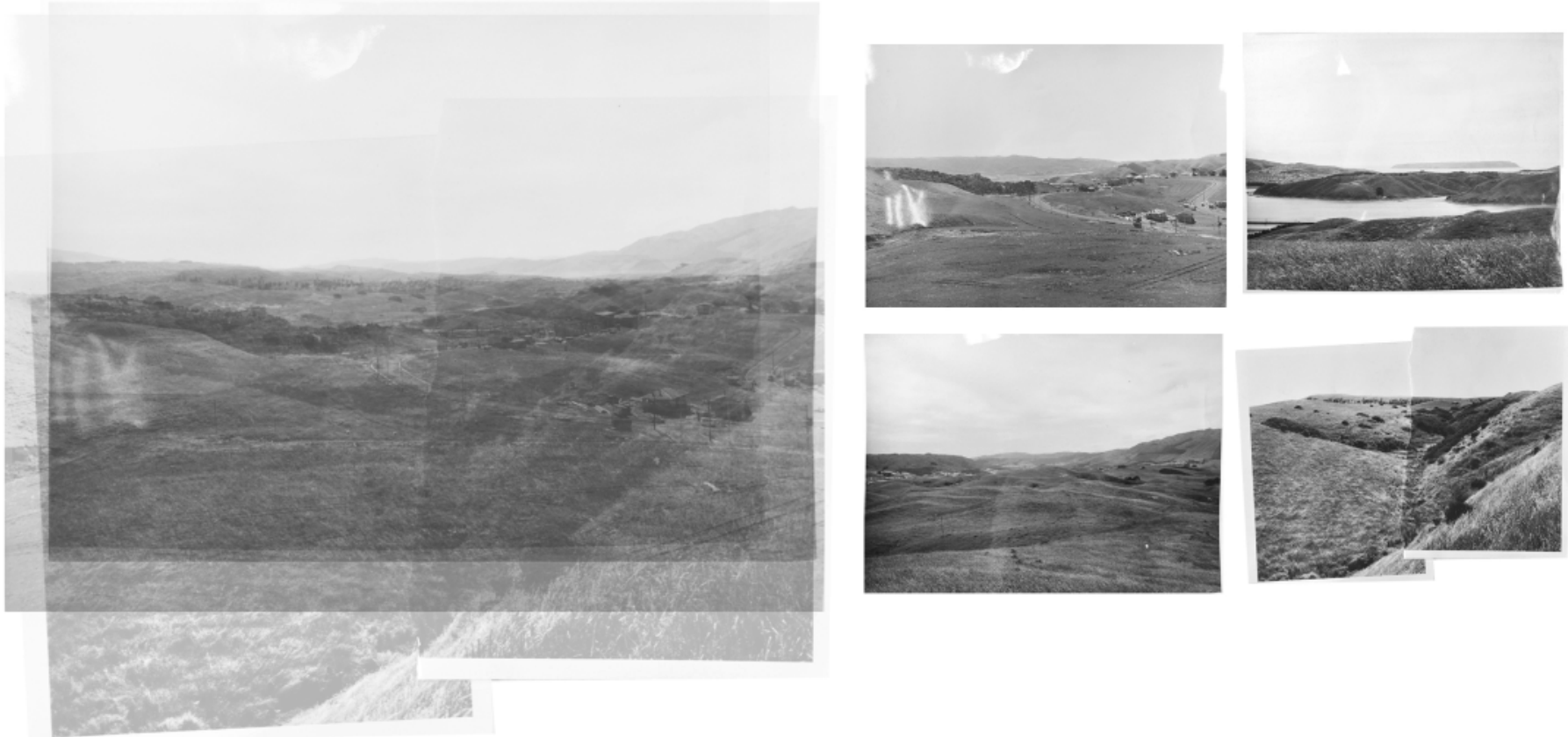

Figure 2.33 Porirua Landscape Overlay Image 2. These images, like the earlier aerial photographs of the landscape, construct a boundless landscape awaiting appropriation. 

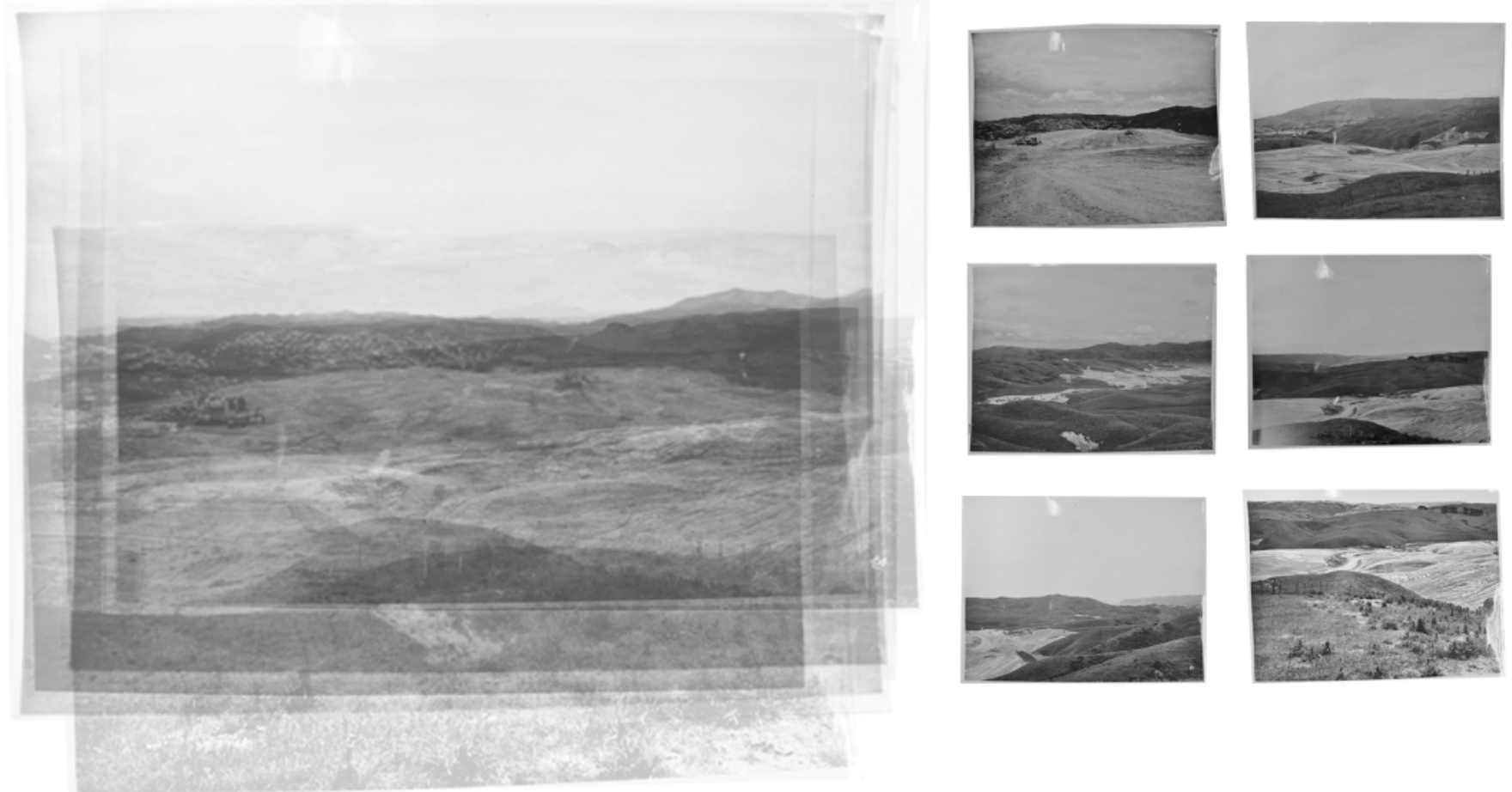

Figure 2.34 Porirua Landscape Overlay Image 3. These images depict landscapes left scoured from cut and fill development, documenting the transformation of the land to a landscape fit for appropriation.
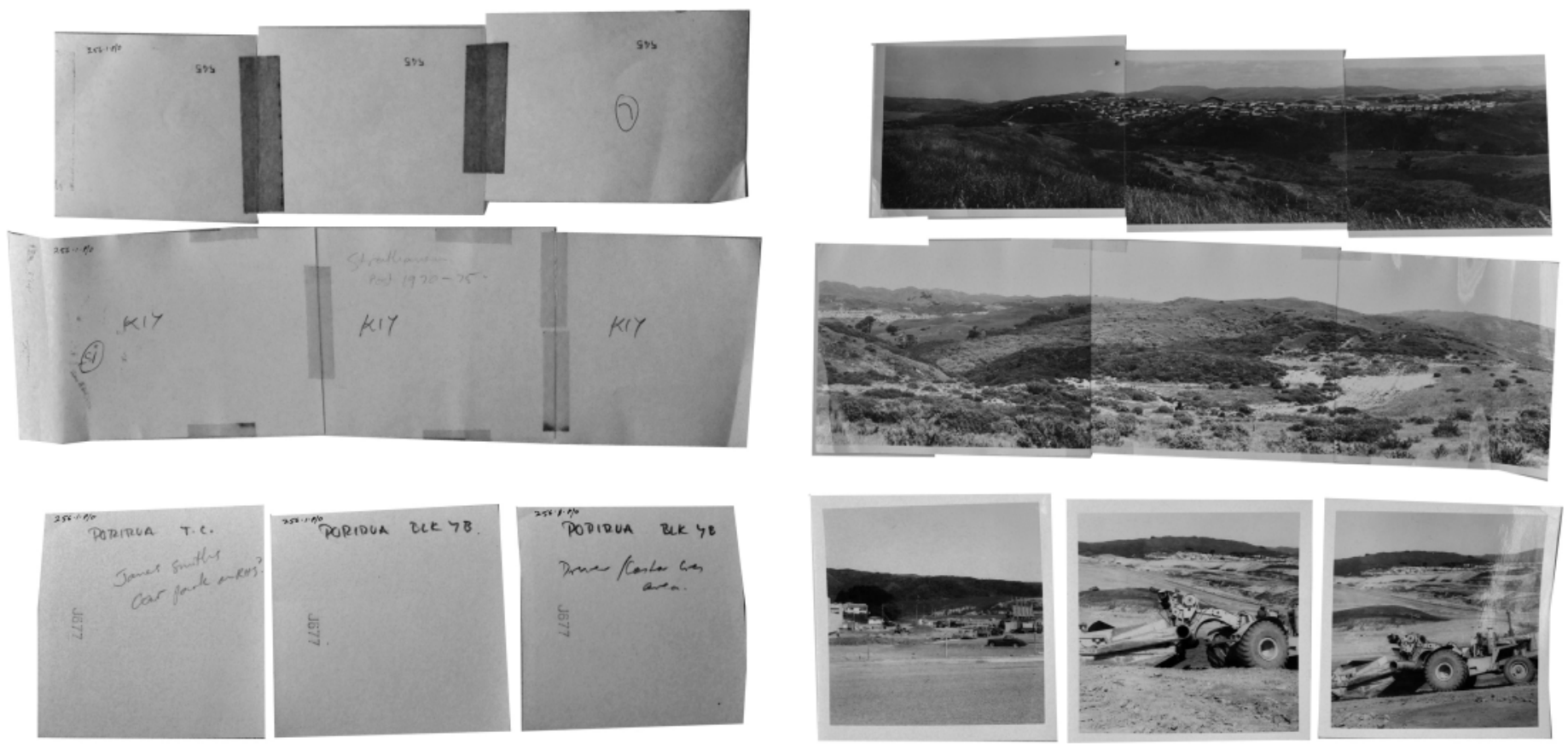

Figure 2.35 Front and Rear of Landscape images from the development of Porirua East. These images are typical of archived photographs from the development within Porirua East, with numbers, rather than names, often being written on the back of photographs for identification. Often little or no writing is on the rear of the photographs which, along with the nature of the photographs themselves, makes many images impossible to locate geographically. The photographs therefore become not depictions of specific places but objective and commoditised spaces fit for appropriation. 

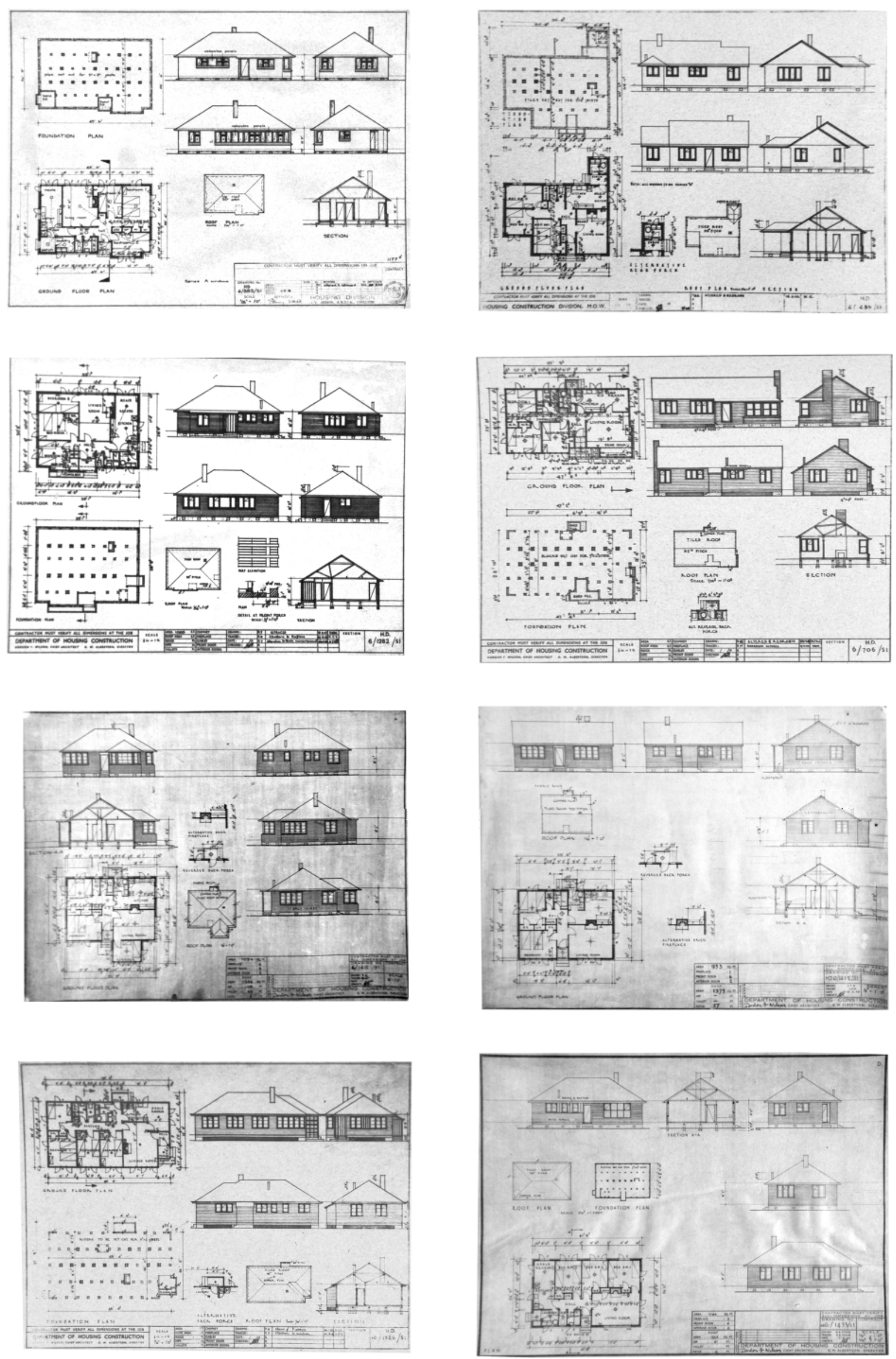

Figure 2.36 Photographs of State House Plans 6/882/S1, 6/1282/S1, 6/1411/S1, 6/1326/S1, 6/1435/S1, 6/1412/S1, 6/706/ S1, 6/635/S1. These images display the typical representation of state houses within state house developments. They present houses that are site-less, autonomous, and interchangeable commodities, rather than pieces of architecture inherently tied to a specific social, cultural, or geographical place. 

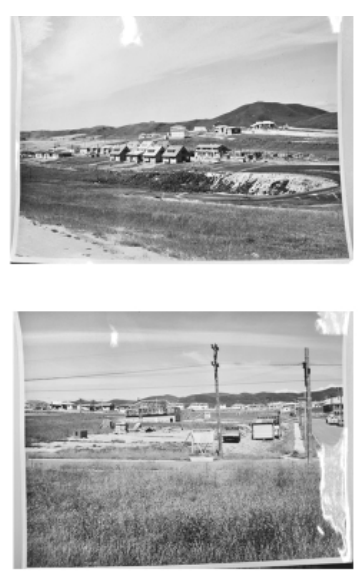
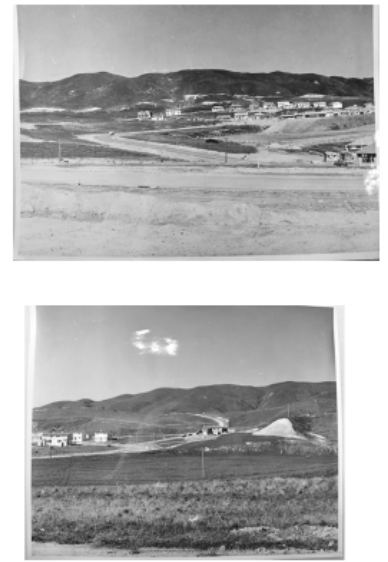
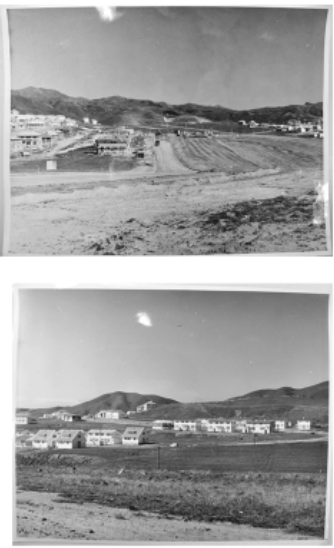

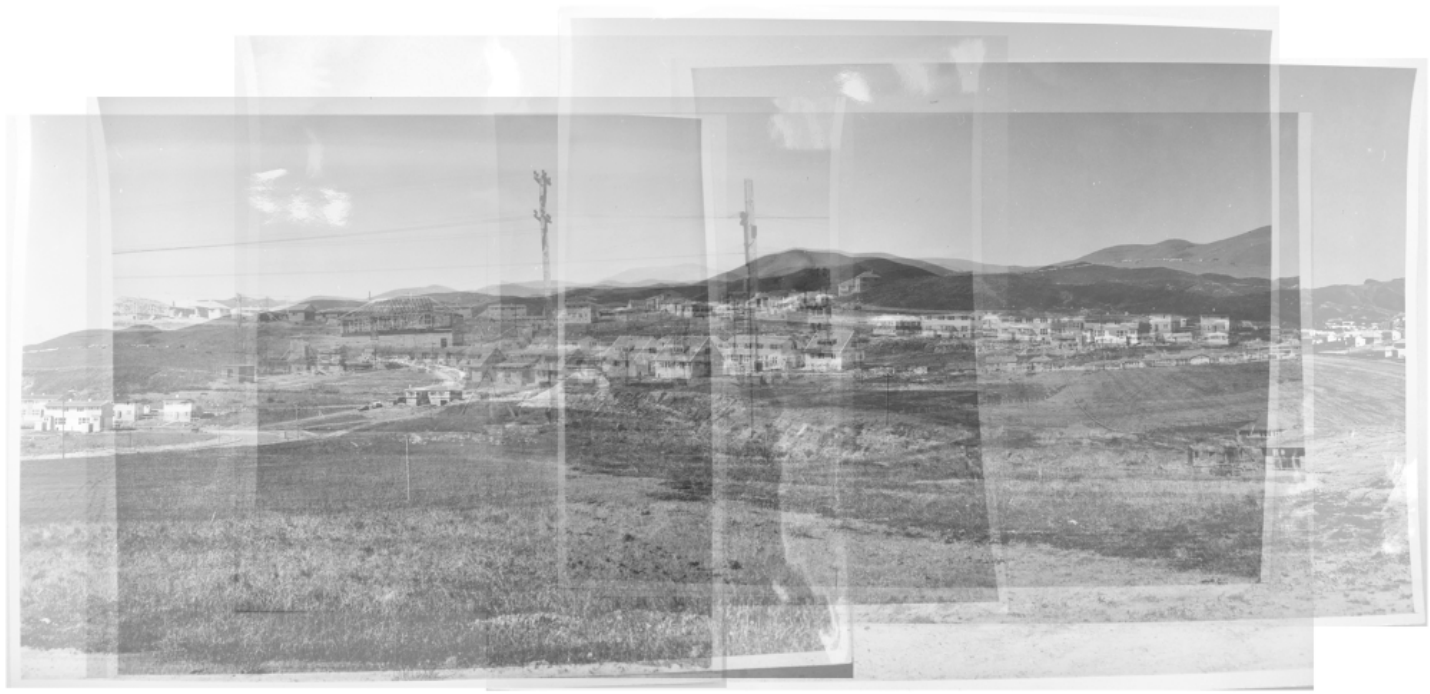

Figure 2.37 Porirua Landscape Overlay Image 4. These images display the documentation of development within Eastern Porirua as it fills in the landscape with its new suburban identity.
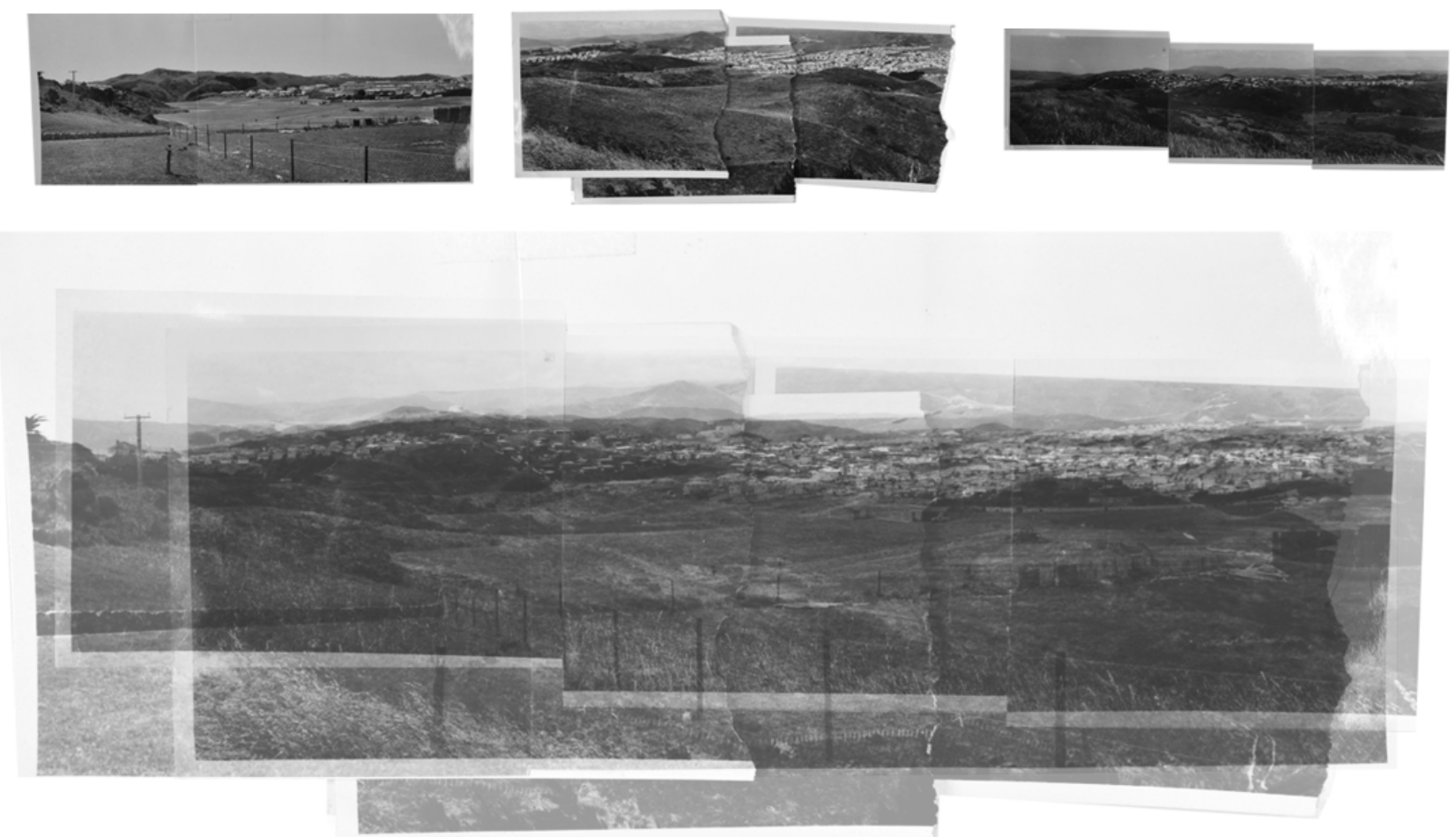

Figure 2.38 Porirua Landscape Overlay Image 5. These images display the documentation of development within Eastern Porirua as it fills in the landscape with its new suburban identity. Like Figure 2.32, individual photographs were ripped and taped together to create a panoramic and panoptic representation of the land. 
The use of these mechanisms of representation within the development of Porirua was not an anomaly, but a continuation of the universal mechanisms used to represent land within colonial society that continues in architectural practice today. Plans and sections are scientific in nature, and are read through codified and objective terms. Thus they define and characterise space and building in relation to these terms and, in this way, privilege mathematical and scientific readings of space. Plans and perspectives too are also panoptic in nature, and are seen to encompass all relevant information, but at the same time value certain information by placing the physical object at the focal centre, legitimising it as the most important element within the representation.

Like the colonial surveying of the land, the dissection and codification of the land within Porirua was not politically inert but used to construct a cultural space that manifested and legitimised the New Zealand government's ideologies surrounding civilised family life. The suburban planning model of State House development was imprinted into the landscape on a large scale, embedding a spatial practice for New Zealand society, which "through education and habit as well as through actual construction" and the "routine degradation of indigenous spatial practices" became "the preferred 'civilised' model for all future habitation" (Fig.2.39)..$^{74}$

Lefebvre argued that the ideology of functionalist urban and architectural planning developed within western capitalist society, and its ultimate manifestation in suburbia, assumed an isomorphism between social and spatial entities, leading to "a simplified theory of needs and functions" which reduced architecture and urban space to mere representations of their own functions. ${ }^{75}$ Founded on the nuclear family as the core social and spatial element, suburbia not only endorsed paternalism and a strict moral order, but also detached itself from the diverse and changing everyday lives of the inhabitants (Fig.2.402.41). ${ }^{76}$ The segregation of needs and their transformation into a closed system of functions concretised a socio-spatial discourse that valued the precise and purposeful organisation, maintenance, and assertion of specific spatial practices (Fig.2.42-2.43)..$^{77}$

The way in which state housing developments were represented at both the landscape and architectural scales was not inert and actively created a cultural space that legitimised state house developments. The mechanisms through which twentieth century state housing developments represented land were inherited from the colonial mechanisms of the material and aesthetic gazes. Consequently, any move towards a postcolonial architecture must be undertaken in the knowledge that the mechanisms by which we represent space within architectural practice inherently favour a colonial reading of land and building. This does not render the pursuit of a post-colonial architecture invalid, but rather confirms that it must challenge architectural mechanisms of representation at some level in order to be valid. Second, the functionalist urban and architectural manner in which State House developments, such as Porirua, divided and structured space was an attempt by the government to embed a spatial practice into New Zealand society. The ability to control and prescribe a spatial system was, for the government, an important tool to degrade indigenous and other spatial practices. It further prescribed an autonomous social identity based the government's egalitarian ideas surrounding civilised life and the nuclear family, and legitimised it as the preferred cultural model for future inhabitation within New Zealand society. 


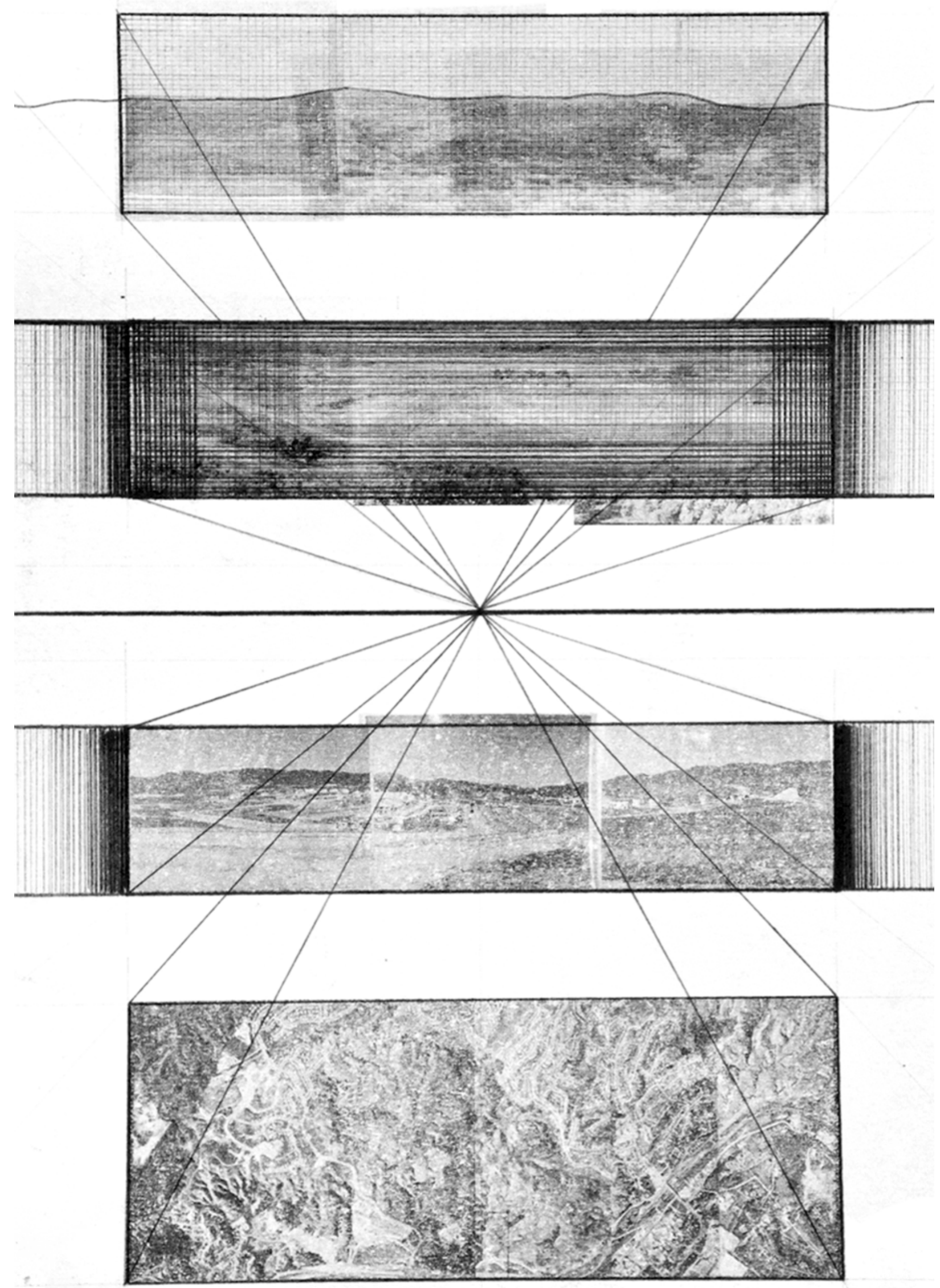

Figure 2.39 Drawing exploring the transformation of the land to landscape in Porirua East. This image explores the process by which mechanisms of representing space constructed a cultural landscape which can then be appropriated and occupied by the identity of state house suburbia. The top image conveys the creation of a boundless landscape, the image below this represents the removal of the identity and subjectivity of the land, the third image conveys the rendering of the landscape in a manner that legitimises appropriation and occupation, and the final image conveys the filling in of this landscape with a new identity. 


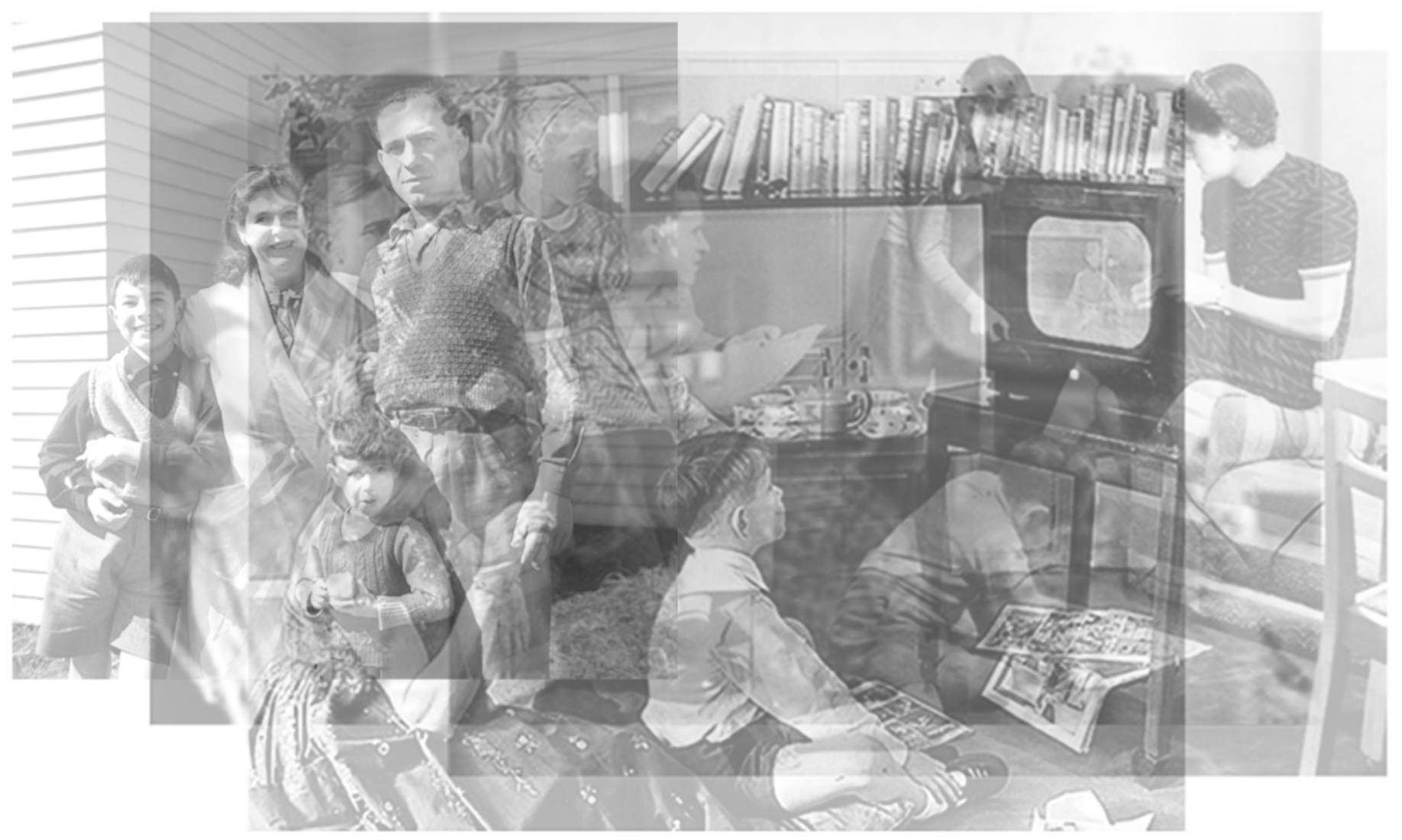

Figure 2.40 State House Nuclear Family Overlay. This image conveys the recurring association of State House developments with nuclear family life, and the presentation of the nuclear family as the moral and civilised life structure for New Zealand society.

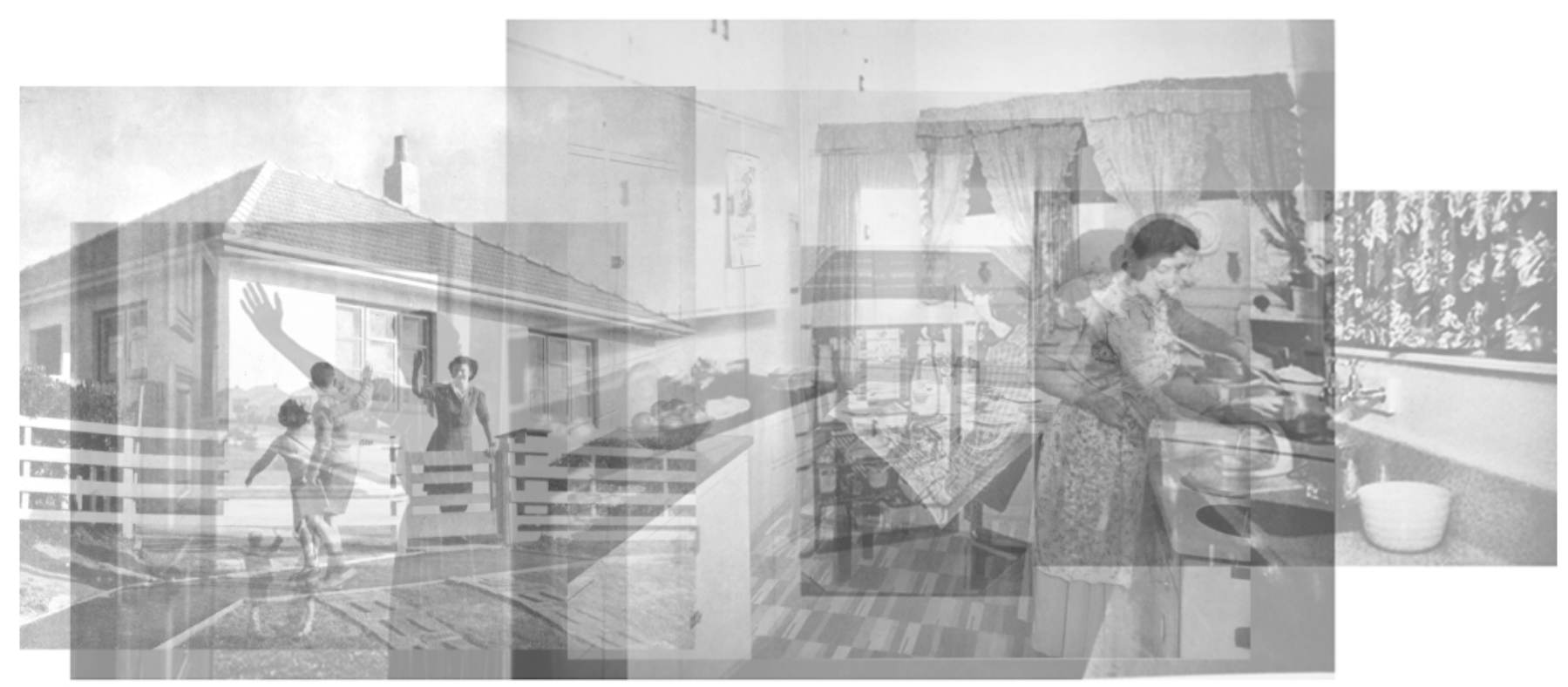

Figure 2.41 State House Female Gender Role Overlay. Like the previous figure, this image conveys a recurring theme within state house imagery. However this image focuses on the closed system of functions prescribed for women within the State House. The women is only realised by her functions as a house mother (e.g. looking after children, cooking, cleaning). She is also bound by the parameters of the house within the images, being shown waving goodbye to her children from within the front porch and behind the property fence as they leave the confines of the house. 


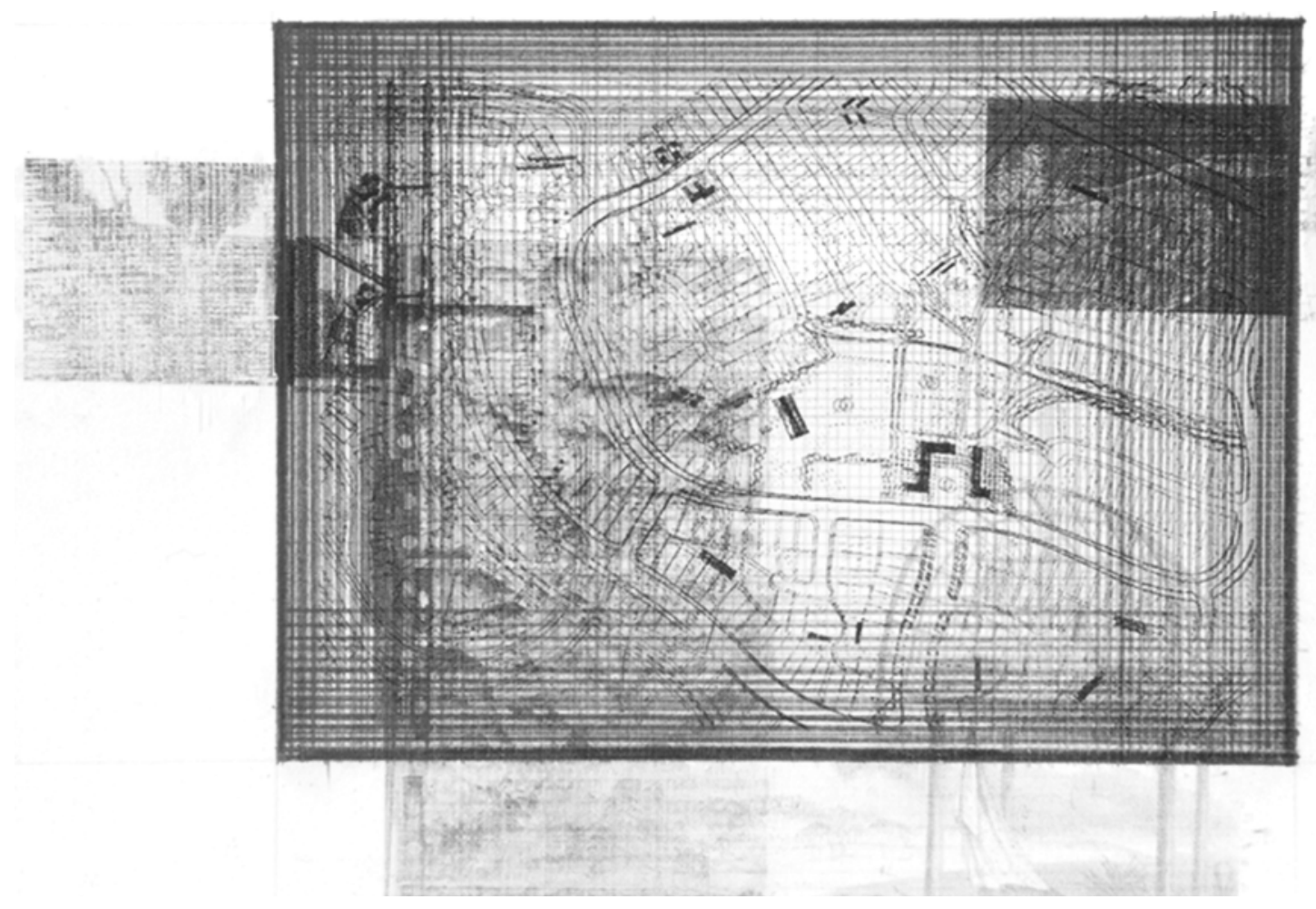

Figure 2.42 Conceptual Drawing of State House Colonial Action 1. This image explores the utilisation of suburban spatial and architectural structures in order to imprint a specific system of functions upon the landscape and New Zealand society, and place under erasure those systems that fall outside of its boundaries.

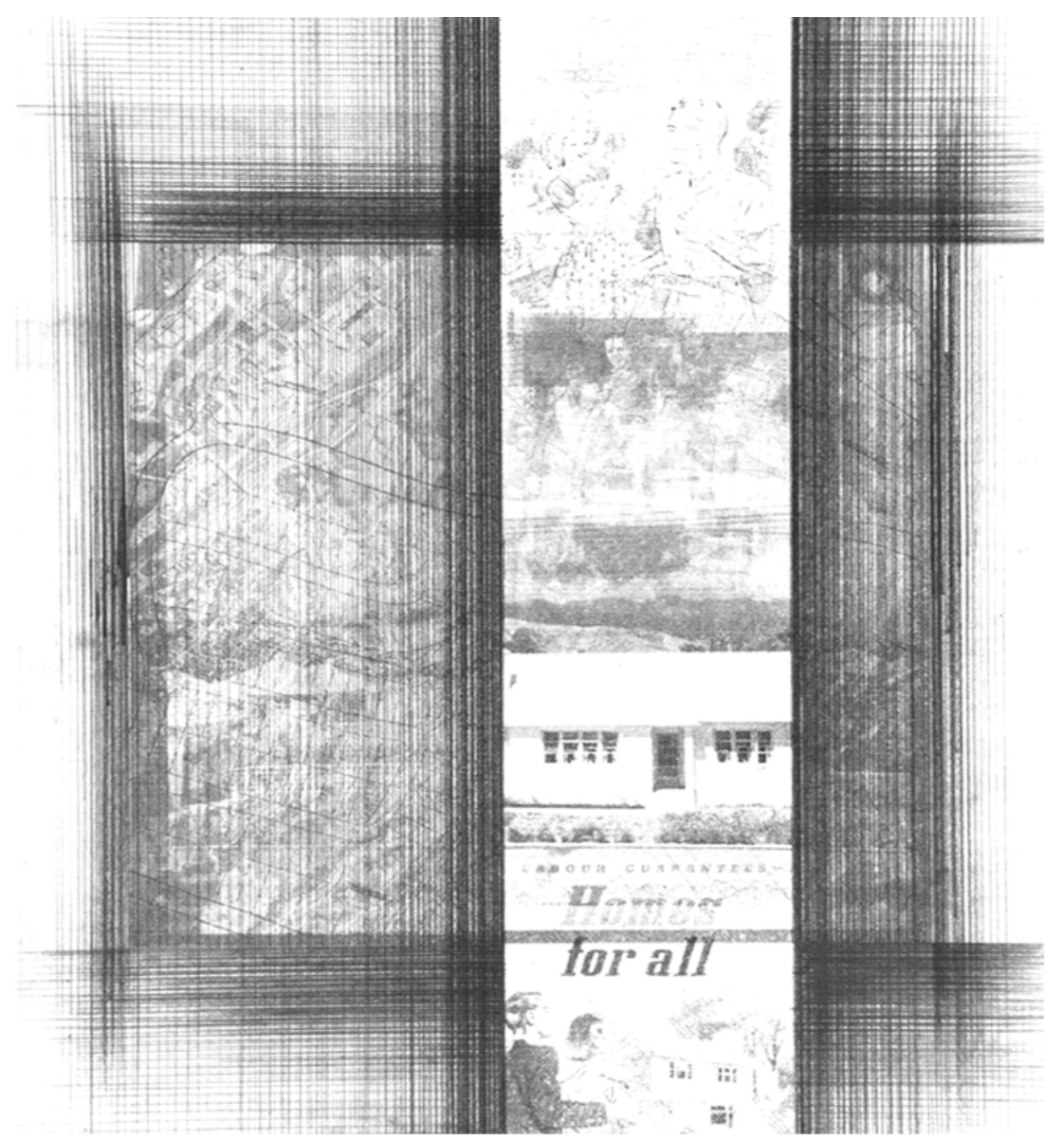

Figure 2.43 Conceptual Drawing of State House Colonial Action 2. This image explores the association of the suburban structure of state house developments with the wholesome image of nuclear family life and the egalitarian ideologies that drove the first state house developments under Labour. 


\section{The Imperial Cultural Object: The State House as an Affirmation of Pākehā Civility and Superiority}

This section extends the discussion above through a contrapuntal ${ }^{78}$ reading of the State House in terms of its relationship to Māori, and investigates the role state housing played in affirming colonial Pākehā culture as natural and superior to Māori culture.

At the beginning of the twentieth century, Māori and Pākehā lived overwhelmingly separate lives, with Māori living in rural environments far away from the cities mainly populated by Pākehā. ${ }^{79}$ It wasn't until after World War II that Māori, some who had fought in the Māori Battalion, began to move into the cities seeking modern conveniences and higher wage employment opportunities. ${ }^{80}$ Throughout the next 40 years Māori undertook an unprecedented geographical shift from rural to urban areas, and by the 1960s this migration began to contest the Pākehā identity that dominated mainstream New Zealand culture. ${ }^{81}$

Brookes observed that the Pākehā vision of suburbia relied upon the image of Māori as exotic, quaint and simple, as it provided a natural backdrop against which the suburbs could comparatively exist (Fig.2.442.46). ${ }^{82}$ She argues "the modernity and sophistication of New Zealand's towns could only be appreciated against the simplicity of the rural hinterland; and the modernity and sophistication of its Pākehā citizens drew on a parallel opposition." ${ }^{83}$ Notwithstanding Brooke's argument, when housing surveys conducted by the Department of Native Affairs showed poor living conditions, such as cooking over open fires, lack of sanitation, and the construction of shacks out of rusting corrugated iron and packing cases, the government was forced to take action. ${ }^{84}$ In 1948 the government agreed to build State Houses specifically for Māori that would be jointly managed by the State Advances Corporation and the Department of Māori Affairs. ${ }^{85}$ Although these houses were specifically for Māori, the designs were almost the same as other State Houses, with the only alteration being the location of the toilet and laundry at the rear of the building. ${ }^{86}$

The procedures for Māori applications for state housing and state lending were complex and open to abuse. ${ }^{87}$ Theoretically, the number of houses provided for Māori was based on the proportion of urgent Māori application to all urgent applications. ${ }^{88}$ However, as Ferguson documents:

Actual practice was very different. The housing division handed over only 97 houses to the DMA between 1948 and 1954. In some cases the State Advances Corporation delayed their allocation because it would create a concentration of Māori in a particular area. Some branch managers resisted allocating houses to Māori and used them for other applicants, thus gradually depleting the total pool. The allocation of houses to the pool bore no relationship to the number of urgent applications. In the 1953-54 year, for example, 356 urgent applications were made by Māori, $15.2 \%$ of the 2,336 total. On that basis 130 of the new 850 homes planned for that year for the Auckland area should have gone into the Māori pool. In March 1953 the Department of Māori Affairs had succeeded in getting a commitment that the housing division would build 40 new houses for the pool. Of the 850 houses proposed only 580 were actually built, of which 88 should have been gone to the Māori pool. Only 26 were delivered. ${ }^{89}$

Additional evidence suggests that discrimination was rife in the private housing sector, even as late as the 1980s. ${ }^{90}$ Such discrimination, and the government's choice to make negligible difference between Māori Affairs houses and State Houses, aligned with the official policy and unofficial social feelings regarding the

78 This term comes from the writing of Said. He states "In practical terms, 'contrapuntal reading' as I have called it means reading a text with an understanding of what is involved when an author shows, for instance, that a colonial sugar plantation is seen as important to the process of maintaining a particular style of life in England ... The point is that contrapuntal reading must take account of both these processes, that of imperialism, and that of resistance to it, which can be done by extending our reading of the texts to include what was once forcibly excluded. Said, 78-79

79 Pool, 133-161, also Walker, Ka Whawhai Tonu Matou, 197-199, 208

80 Walker, Ka Whawhai Tonu Matou, 197-199

81 Schrader, We Call it Home, 128-129

82 Brookes, 213

83 Brookes, 213

84 Schrader, We Call it Home, 57

85 Schrader, We Call it Home, 57

86 Schrader, We Call it Home, 129

87 Ferguson, 221

88 Ferguson, 220

89 Ferguson, 220-221

90 A 1986 survey conducted by the Race Relations Conciliator found most Auckland landlords believed Māori and Pacific people to be dirtier, less house-proud, and more likely to overcrowd properties than Pākehā, with one landlord commenting "My house is very quiet because I don't have many Māoris or Islanders... I don't like black people. They smoke and drink. They'll wreck the place." [Macdonald, 82-83, 87-88] In addition, a remit sponsored by Dorothy Harlen, the wife of a Hastings city councillor, called for limitation of houses allocated to Polynesian people as she believed they were the reason behind a rise in local theft and vandalism, and that is was not possible for the community to have such a high proportion of Màori without "spreading the disease" and didn't want to bring her standards "down to their level." Schrader, We Call it Home, 200 


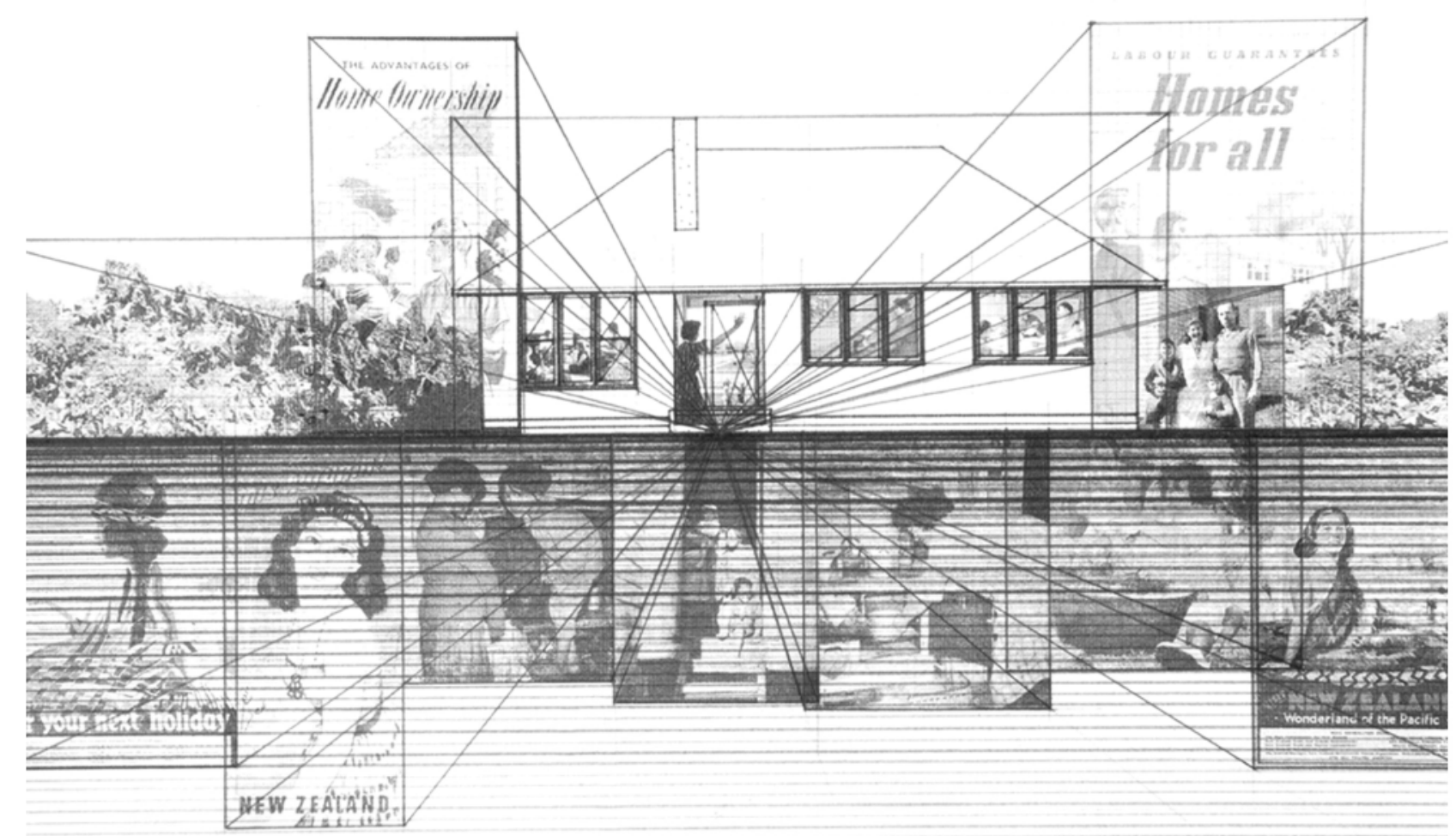

Figure 2.44 Conceptual Drawing of State House Imperial Action 1. This image explores Barbara Brookes' argument that the identity of the state house relied upon an opposition to Māori culture, and a characterisation of Māori as quaint, exotic, rural, and living 'a backwards life in primitive conditions'.

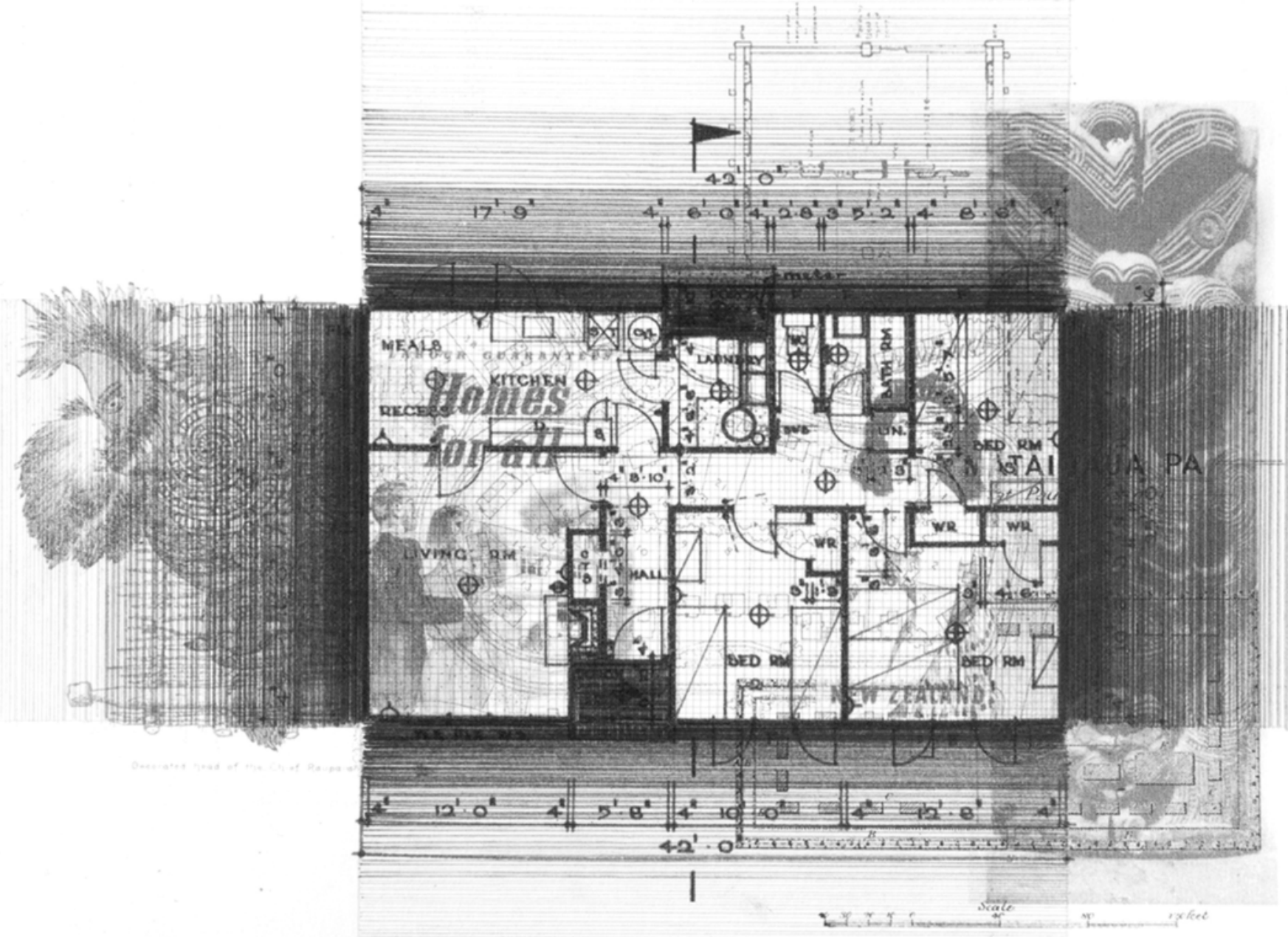

Figure 2.45 Conceptual Drawing of State House Imperial Action 2. This image also explores Barbara Brookes' argument but through a plan based drawing. 


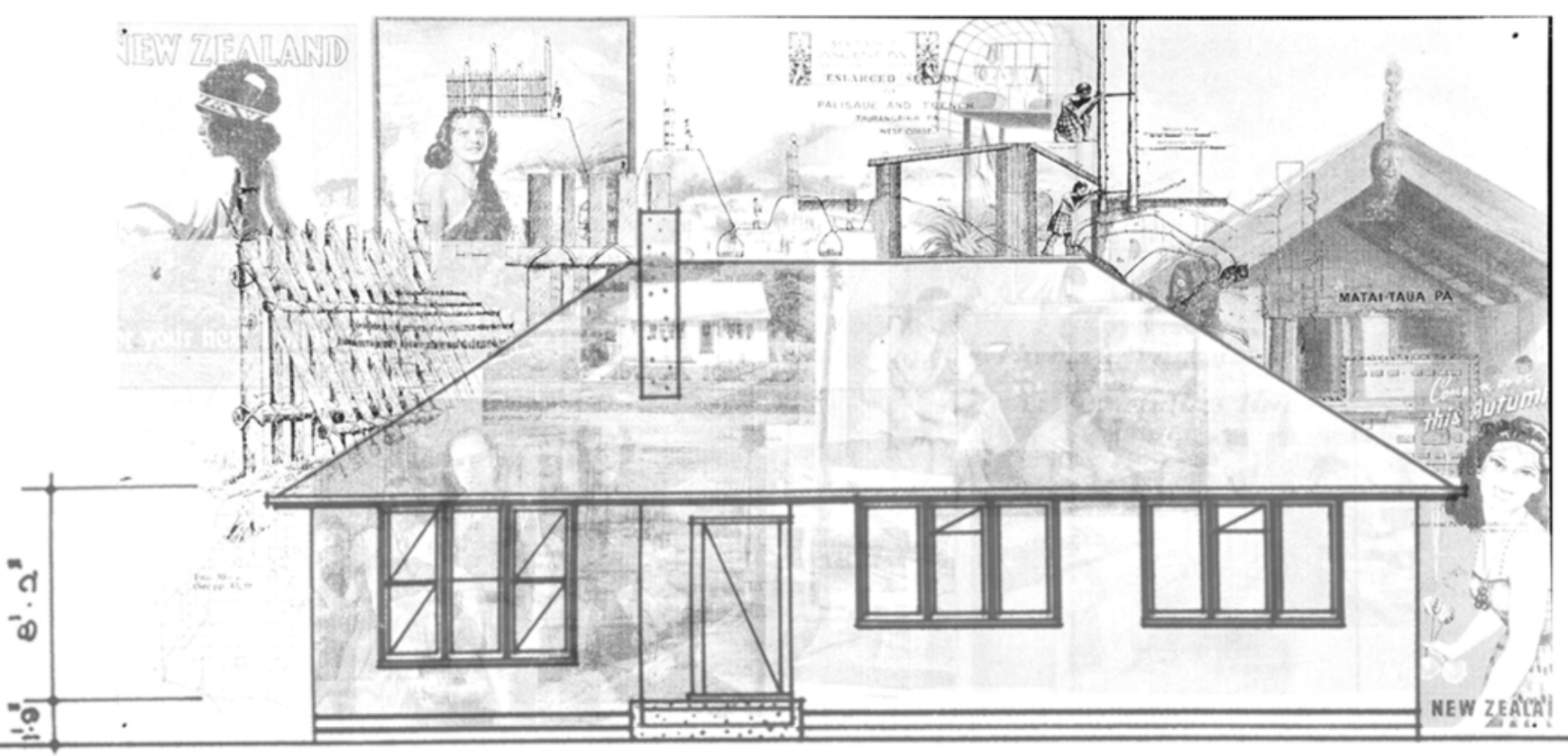

Figure 2.46 Conceptual Drawing of State House Imperial Action 3. This image explores Barbara Brookes' argument that the identity of the state house relied upon an opposition to Māori culture, and a characterisation of Māori as quaint, exotic, rural, and living 'a backwards life in primitive conditions'.

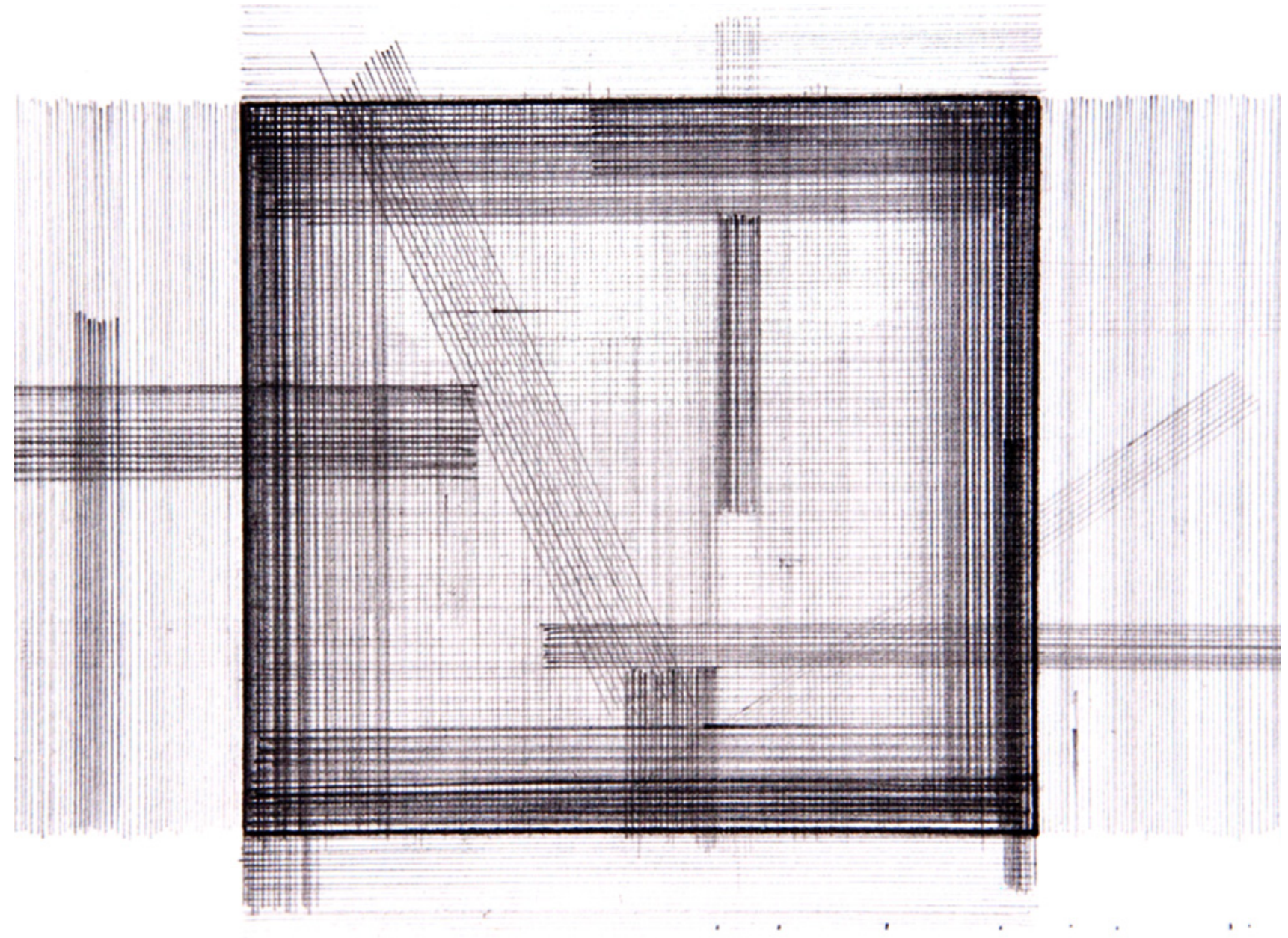

Figure 2.47 Conceptual Drawing of State House Imperial Action 4. This image explores the notion that the state house relied upon classifying alternate identities and spatial practices that fell outside of its frame in terms of its own system or rules of classification in order to classify them as other and inferior. 
integration of Māori into Pākehā society. ${ }^{91}$

Māori were assigned to State Houses through the method of 'pepper-potting' them among Pākehā, to encourage Māori to adjust themselves generally to the Pākehā way of living. ${ }^{92}$ In practice, however, rather than grouping people together, this policy, and the suburban environment, removed Māori from the support structure of their whānau and marae. The process further isolated people who were already seen as different and inferior, and put pressure upon them to integrate to the dominant nuclear Pākehà family lifestyle (Fig.2.47). ${ }^{93}$

Additionally, almost all detached State House designs up until the 1960s, when low roof pitches and the removal of projecting porches occurred, abided by the neo-Georgian cottage style, characterised by simple gabled or hipped roofs with tight eaves, three-light casement windows and simple, clean detailing. The use of this style was dictated by guidelines that stipulated that State Houses were to have a dominant roof mass and be in the general style of the English cottage. ${ }^{94}$

For the New Zealand Government and New Zealand's architectural elite, Neo-Georgianism and the English cottage represented the height of sophistication and morality. ${ }^{95}$ In the 1946 promotional film for Labour's state housing programme, Housing in New Zealand, Neo-Georgian colonial cottages were presented as "houses that weren't modernistic, or period, or quaint, but faced the sun and suited the climate and didn't pretend to be anything else but good common sense houses for New Zealanders to live in." ${ }^{96}$ Held up as a particularly strong example was James Busby's House at Waitangi, New Zealand's first government built house. ${ }^{97}$ The reference to Busby's house confirms the utilisation of the State House to transform space "sufficiently as to no longer appear foreign to the imperial eye" (Fig.2.48-2.50) ${ }^{98}$ In referencing Busby's House and Neo-Georgian colonial cottages in State House aesthetics, the government not only characterised New Zealand as a colonial space of the British Empire, but also affirmed British spatial practices and architecture as superior to indigenous Māori equivalents (Fig.2.51-2.52). ${ }^{99}$ As such, the State House largely failed to encompass any Māori narratives, practical, conceptual or formal, into its design. Utilising Māori narratives and spatial practices within the architecture that represented New Zealand's home apparently was not considered, and implementing such an action would have run contradictory to social attitudes and the government's official policy regarding Māori. ${ }^{100}$

\begin{abstract}
91 For example in the 1961 Report on Department of Mãori Affairs, the acting secretary of Mãori Affairs, Jack Hunn, prescribed the government's approach to the 'issue', and made several recommendations on social reforms affecting Mãori. The report organised Māori into three categories: "a completely detribalised minority whose Māoritanga is only vestigial ... the main body of Māori, pretty much at home in either society, and a minority complacently living a backward life in primitive conditions." The report recommended that the government raise the last group to the same condition as the second, and leave it to Māori to decide if they wanted to join the first, as it was assumed they, in time, naturally would. The report also recommended the encouragement of urbanisation and the use of social and housing policies as a means of achieving what Hunn termed integration. Hunn, 14-16 92 During the late 1950s and 1960s, the increasing number of Mãori and Pacific people in need of state housing gradually made the practice of 'pepper-potting' more difficult, and by the end of the 1960s the use of state housing as a form of welfare provision took over and gave Māori access to state housing on the same basis as Pākehā. However, this, like the earlier provisions for Māori in the 1930s and 40s, was a response to growing impoverishment rather than a belief that Māori were disadvantaged in the housing market. It was, in fact, not until the later 1970s that the state would accept that Māori were in special need of housing because they faced discrimination in the housing market and had particular cultural needs. Ferguson, 216, also Schrader, We Call it Home, 57
\end{abstract}

93 Ferguson, 204-219, also Walker, Ka Whawhai Tonu Matou, 197-199

94 Toomath, 173-174, also Schrader, We Call it Home, 88

95 Schrader, We Call it Home, 90

96 Housing in New Zealand (1946) [video recording], also Schrader, Labour at Home, 133-134

97 New Zealand History Online, "The Treaty House at Waitangi"

98 Said, 226

99 Austin argues: The first commentator on New Zealand architecture is generally taken to be Hurst Seager, who said at the beginning of the twentieth century, "Here in New Zealand the only historical examples of art we have are the works of the Māoris; and these, though excellent examples of savage art are scarcely suitable as standards in which to found our national taste". [Hurst Seager, 490] This relies on a clear and comfortable distinction that was at the crux of the modernist architect and theorist Adolf Loos's proposition that ornament was fine for savages, but does not do for the civilised. This distinction continues with Knight's pronouncement fifty years later, where civilisation is qualified as British, "The Māori race, dominant in some other fields, had little architectural influence. They have, it is true, a native architecture interesting and valuable from a historical point of view, but it served a way of living entirely opposed to the British civilisation. Apart from some influence in detailed ornament it could have little effect upon contemporary design." [Knight, 180-181] Māori are confined to the ornamental in much the same way as the same way that the role of Măori people in Aotearoa/New Zealand public life used to be restricted to the entertainer. Austin, "Biculturalism and Architecture in Aotearoa/New Zealand", 46

100 Austin, "Biculturalism and Architecture in Aoteroa/New Zealand", 46, also Ferguson, 216 


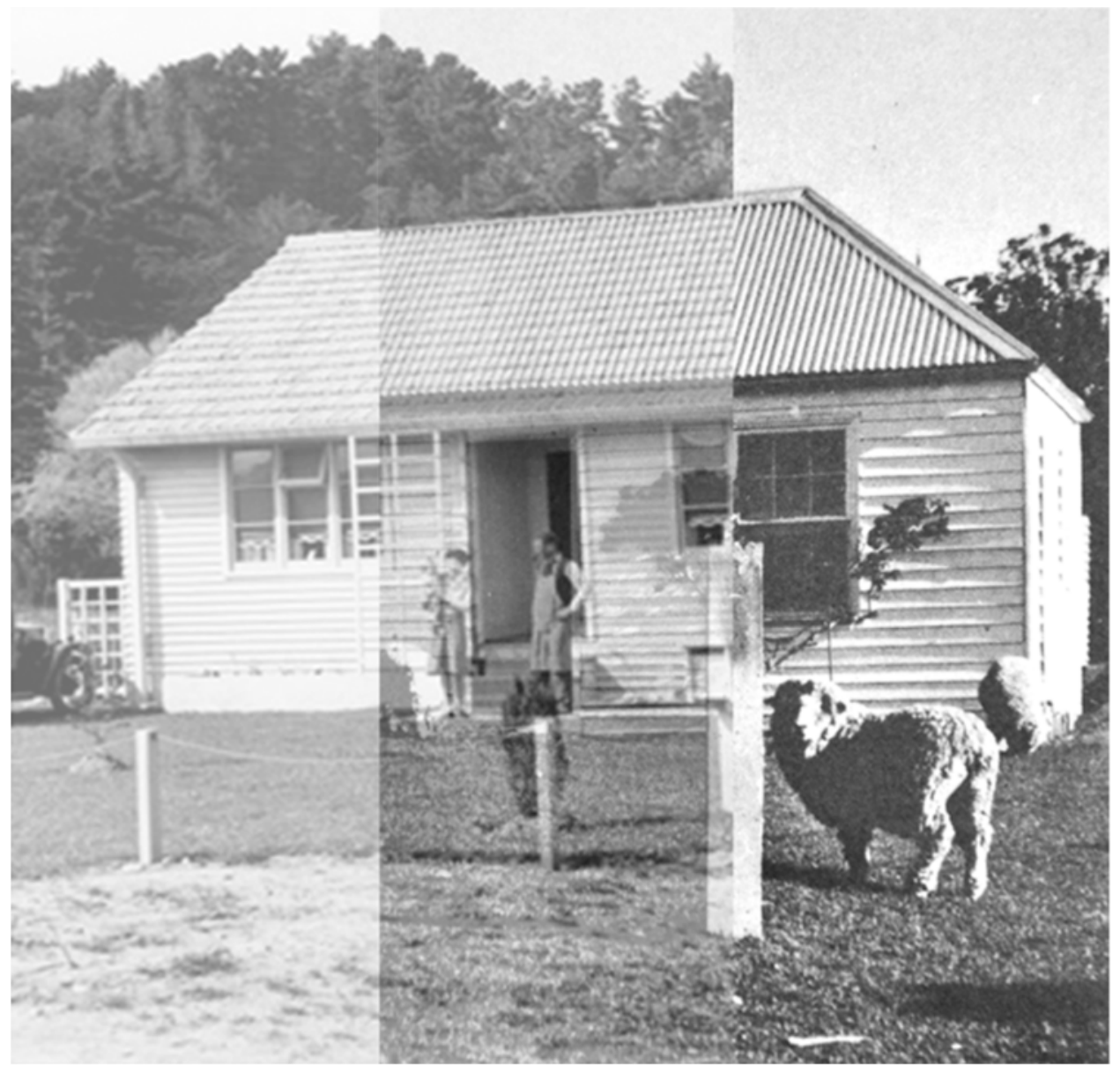

Figure 2.48 Conceptual Drawing Exploring the Link Between the State House and the Colonial NeoGeorgian Cottage 1.

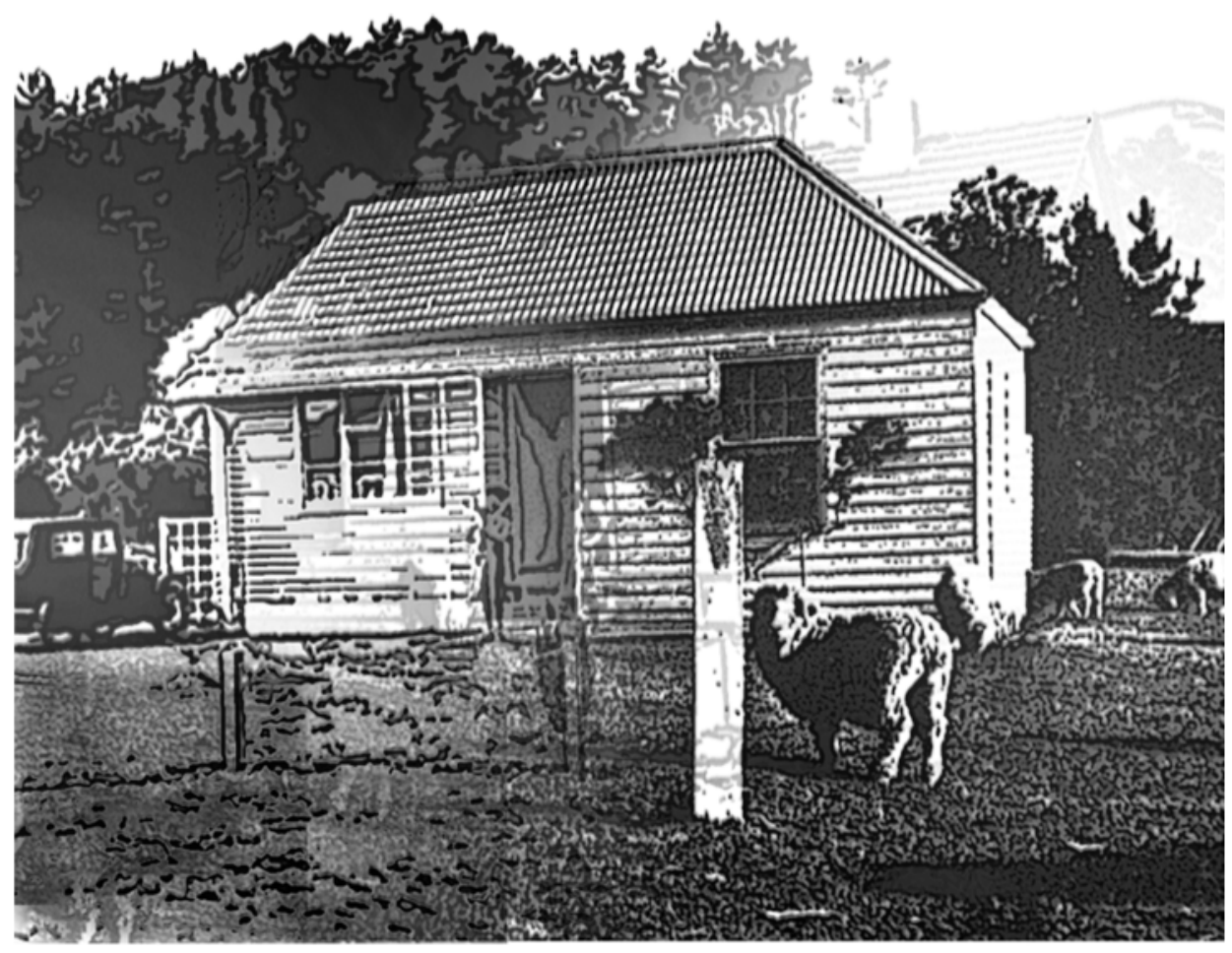

Figure 2.49 Conceptual Drawing Exploring the Link Between the State House and the Colonial NeoGeorgian Cottage 2. 

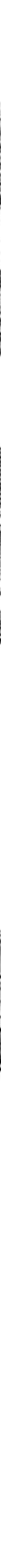

Figure 2.50 Conceptual Drawing Exploring the Link Between the State House and the Colonial Neo-Georgian Cottage 3. This drawing explores the utilisation of the state house to reference the initial colonisation of New Zealand, and to confirm New Zealand as a colonial space of the British Empire. It uses various images to trace the lineage of the New Zealand state house right back to James Busby's house at Waitangi, which is referenced in the film State Housing in New Zealand. 


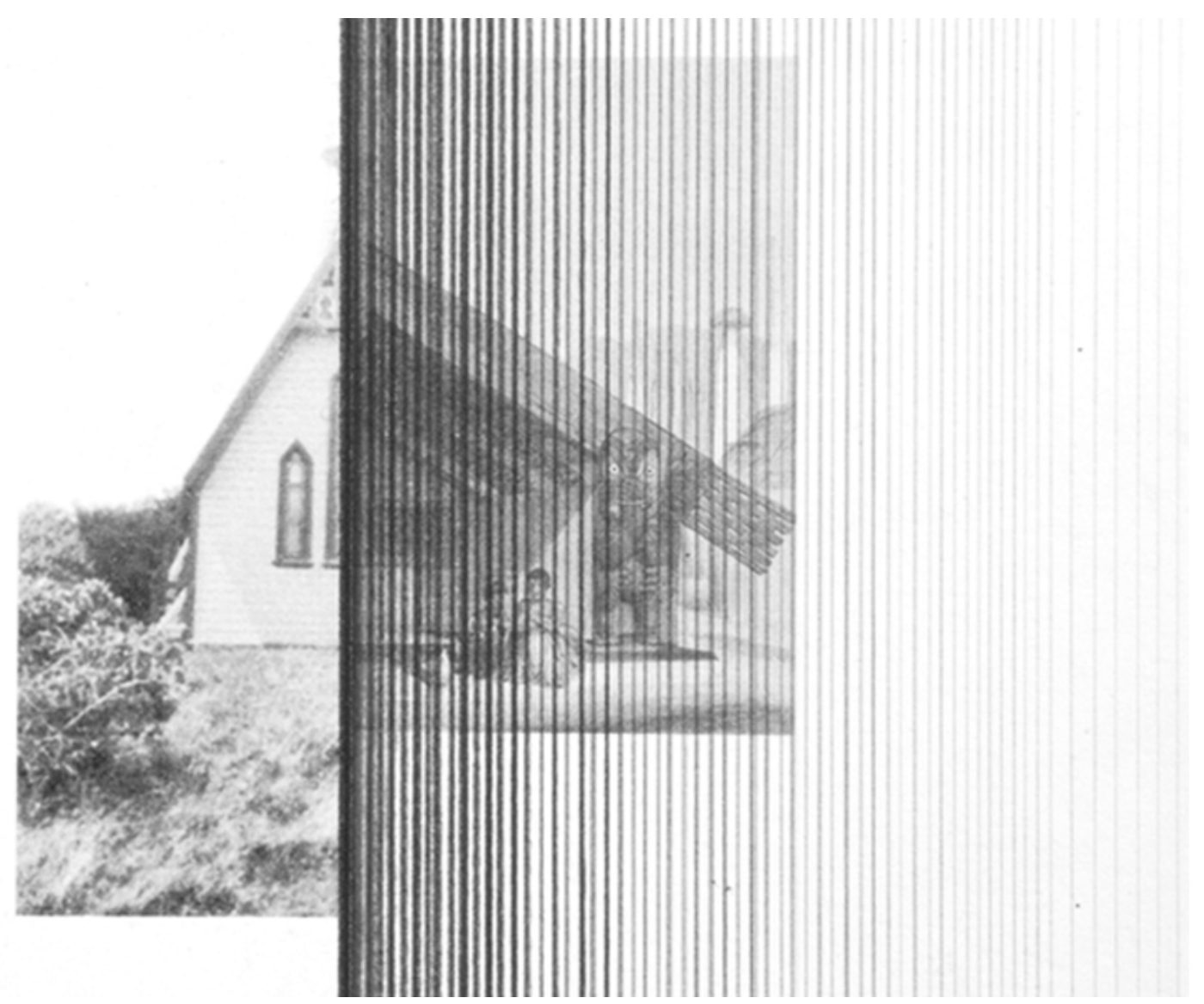

Figure 2.51 Conceptual Drawing Exploring the opposition between colonial and Mãori socio-spatial life and architecture 1. This drawing explores the opposition between the church and the wharenui/marae as the central piece of social architecture within European and Māori life.

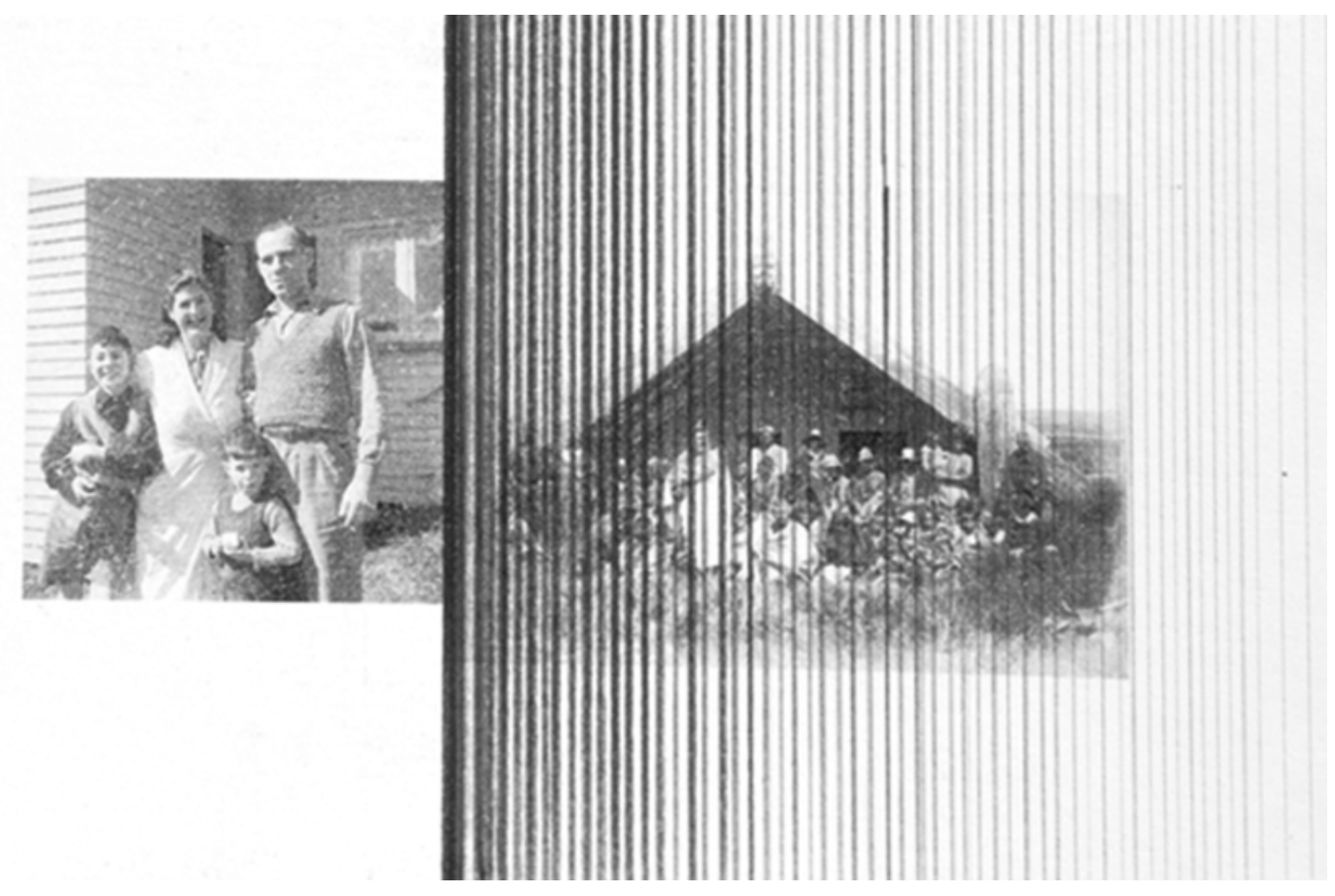

Figure 2.52 Conceptual Drawing Exploring the opposition between colonial and Māori socio-spatial life and architecture 2. This drawing explores the opposition between the suburban and nuclear family identity and spatial structure of state house developments and the collective and iwi based identity and spatial structure of Māori culture. 


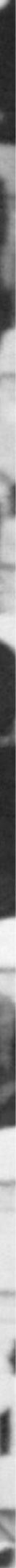
IN EASTERN PORIRUA

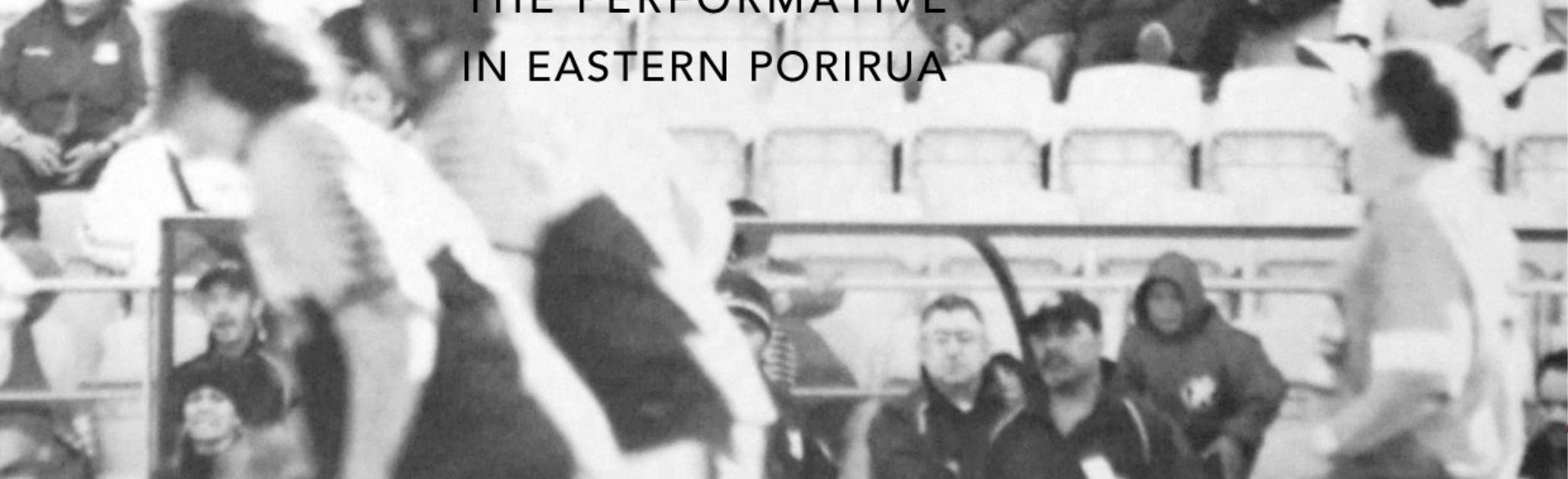




\section{Chapter Three: Site Analysis: An Investigation into Lived Space and the Performative in the Suburbs of Eastern Porirua}

This chapter engages with Lefebvre's and Bhabha's theories of lived space and the performative. Specifically, it investigates how State House inhabitants within Eastern Porirua, New Zealand's largest State House development, have challenged the socio-spatial narratives of the State House. The chapter begins with a short introduction to Eastern Porirua, after which empirical evidence documenting current spatial practices within the area will be analysed. Following this, a list of criteria and requirements that the designs must meet in order to be practically successful for contemporary inhabitants, will be established.

\section{Introduction to Eastern Porirua}

Eastern Porirua is an area that comprises the residential suburbs east of the Porirua City centre and State Highway one; namely Porirua East, Cannons Creek, Waitangirua and Ascot Park. ${ }^{101}$ The population within Eastern Porirua is more culturally diverse than the rest of greater Wellington and New Zealand, with the most common ethnic group being Pacific Peoples. The area also has similar numbers of Māori and Pākehā peoples. Census data from the suburbs identified above also show a population that, comparatively to the rest of New Zealand, has:

- A younger average age

- Lower rates of post-school qualification

- Lower average incomes and higher rates of unemployment

- Higher rates of single parent families

- Lower rates of one person households and higher rates of two family households

- Lower rates of household access to phones and the internet

- Less access to motor vehicles

- Lower rates of home ownership. ${ }^{102}$

The last of these statistics is largely due to the prevalence of state rental properties within the region, which still remains high despite the selling of State House stock over the past 60 years.

A 2005 suburban character study ${ }^{103}$ conveyed the typical state house suburban layout, with residential density groups of individual buildings lying on curved, looped, and cul-de-sac style roads, sited within softly undulating valleys and surrounded by hills, with houses most often covering only between 15-35\% of their sections (Fig.3.1-3.6).

101 The suburb of Porirua East was the first to be developed in the 1950s, with development slowly spreading eastwards from the western to eastern side of Cannons Creek to Waitangirua through the later 1950s and throughout the 1960s. Ascot Park, which lies north of Waitangirua, was developed in the later parts of the twentieth century, and does not possess the same concentrations of state housing as the other suburbs within the area.

102 Statistics New Zealand. "Cannons Creek East Community Profile.”, also Statistics New Zealand. "Cannons Creek North Community Profile.", and Statistics New Zealand. "Cannons Creek South Community Profile."

103 Commissioned by Porirua City Council and prepared by Boffa Miskell Ltd. and Graeme McIndoe Architect \& Urban Designer 


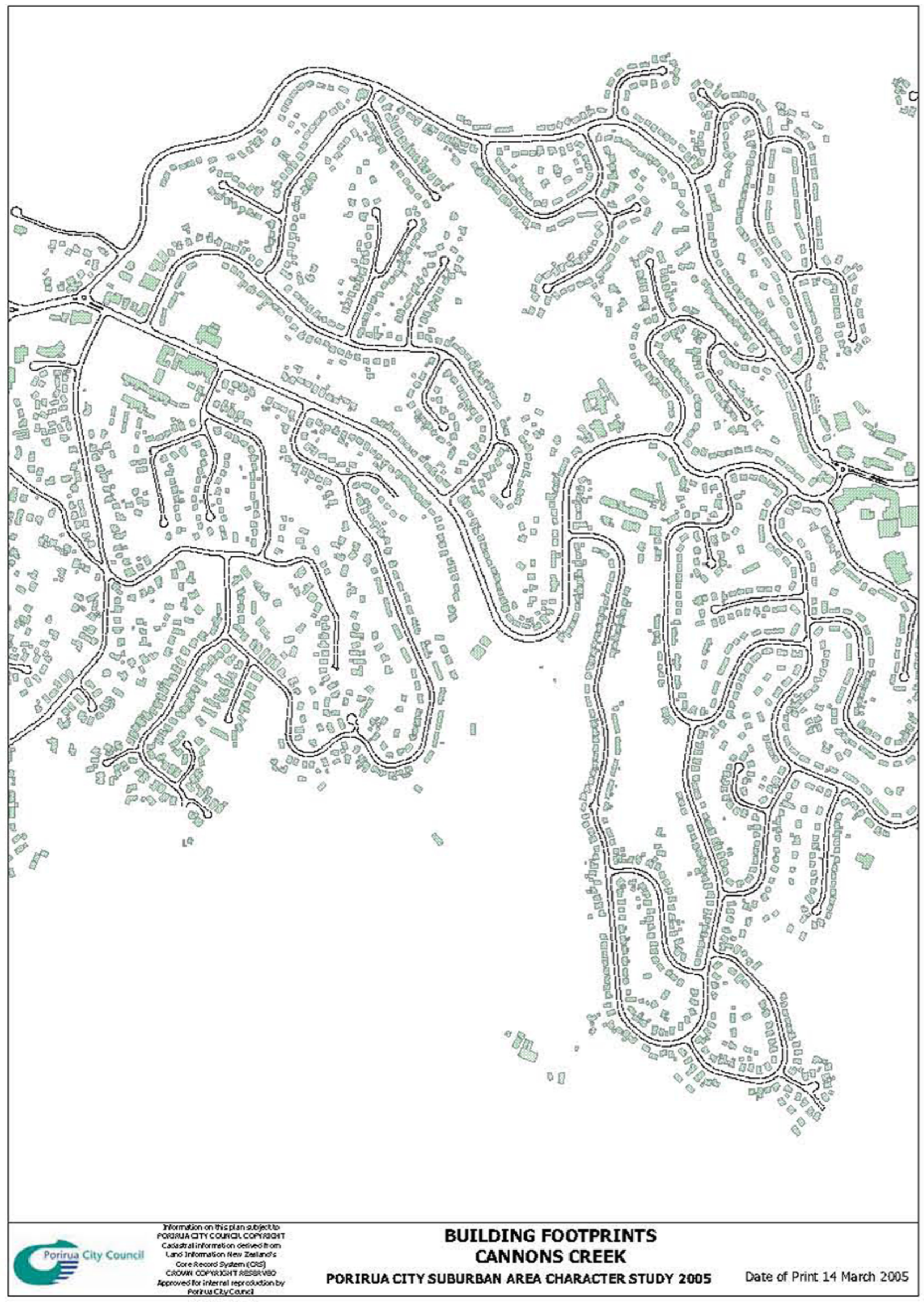

Figure 3.1 Building Footprints: Cannons Creek. Boffa Miskell Ltd and Graeme McLindoe Architect \& Urban Designer, "Appendix Five: Building Footprint and Street Layout", Porirua Suburban Character Study, (Porirua: Porirua City Council, 2005), 75 


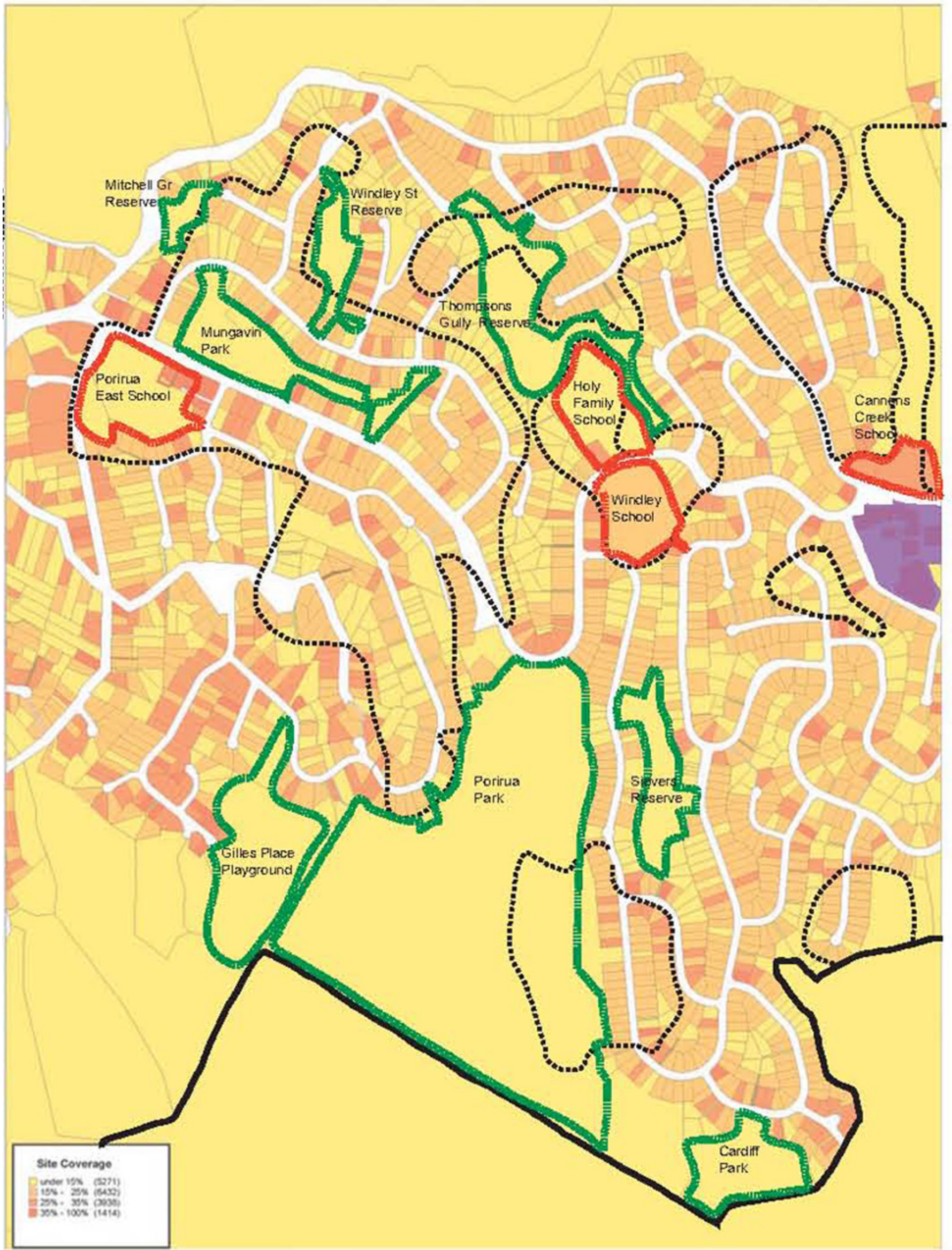



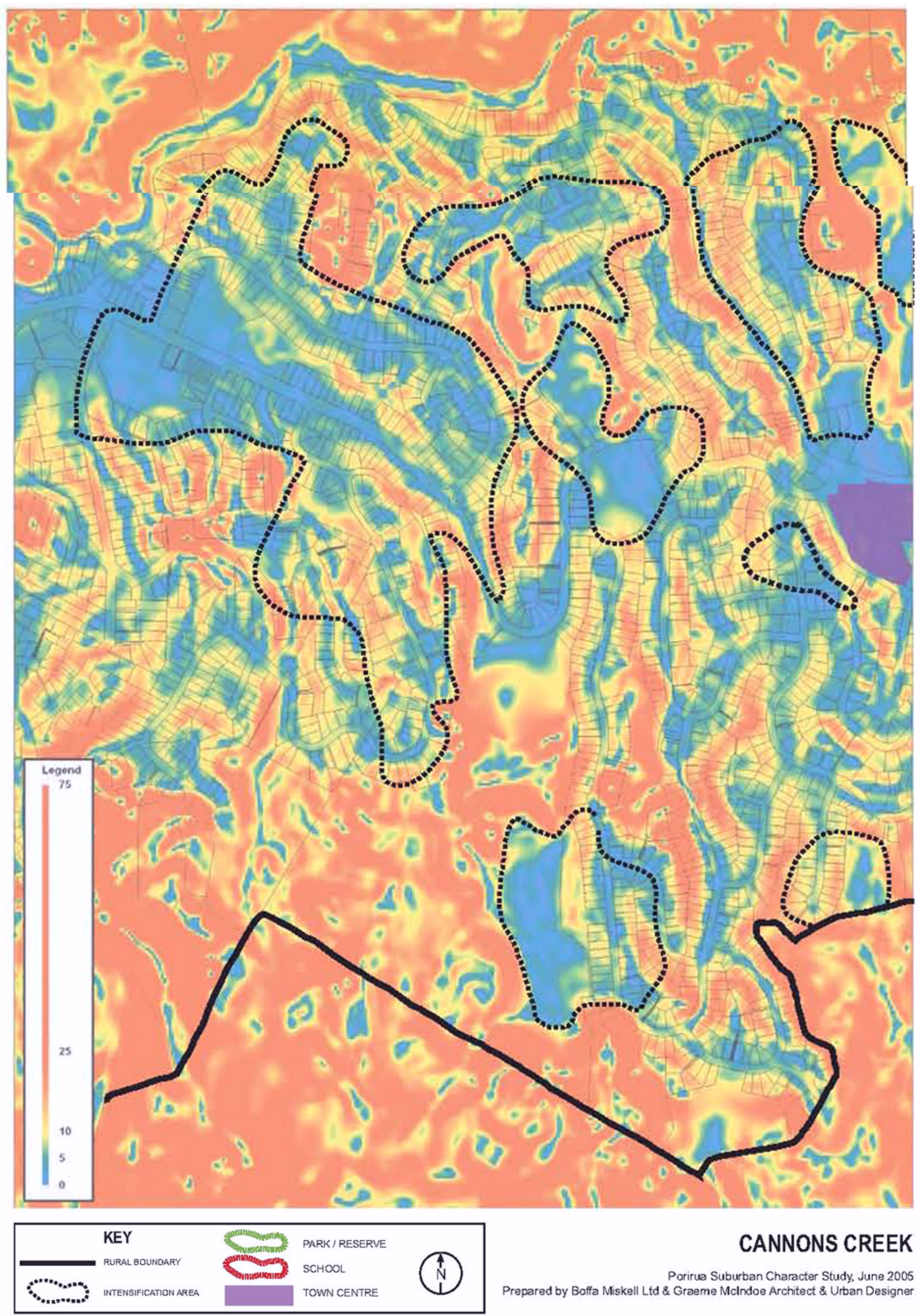

CANNONS CREEK

Porirua Suburban Character Study, June 2005 Prepared by Boffa Miskell Ltd \& Graeme Mclndoe Architect \& Urban Designer

Figure 3.3 Slope Analysis: Cannons Creek. Boffa Miskell Ltd and Graeme McLindoe Architect \& Urban Designer, "Appendix Four: Slope Analysis and Site Coverage Maps", Porirua Suburban Character Study, (Porirua: Porirua City Council, 2005), 65 


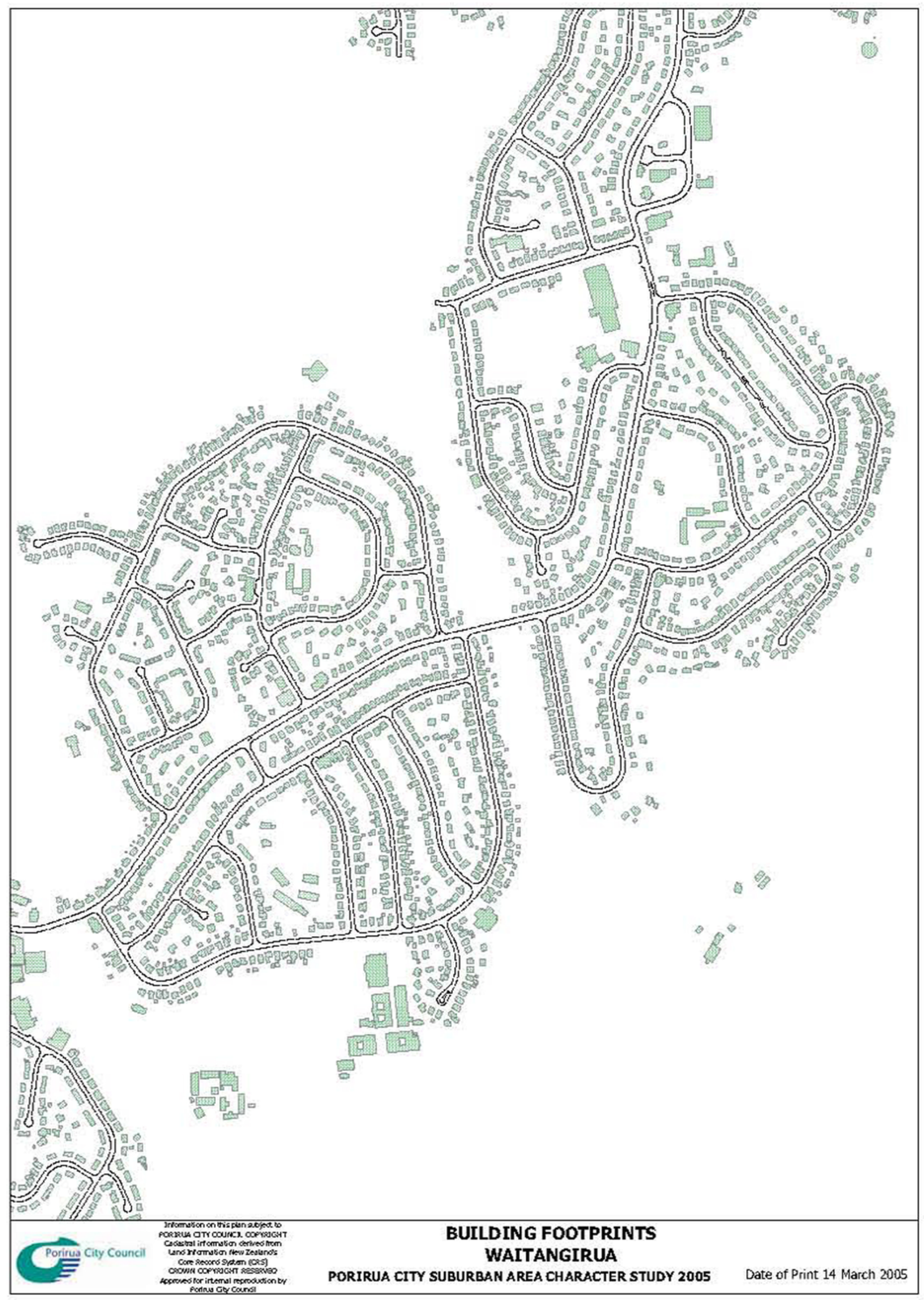

Figure 3.4 Building Footprints: Waitangirua, Boffa Miskell Ltd and Graeme McLindoe Architect \& Urban Designer, "Appendix Five: Building Footprint and Street Layout", Porirua Suburban Character Study, (Porirua: Porirua City Council, 2005), 74 


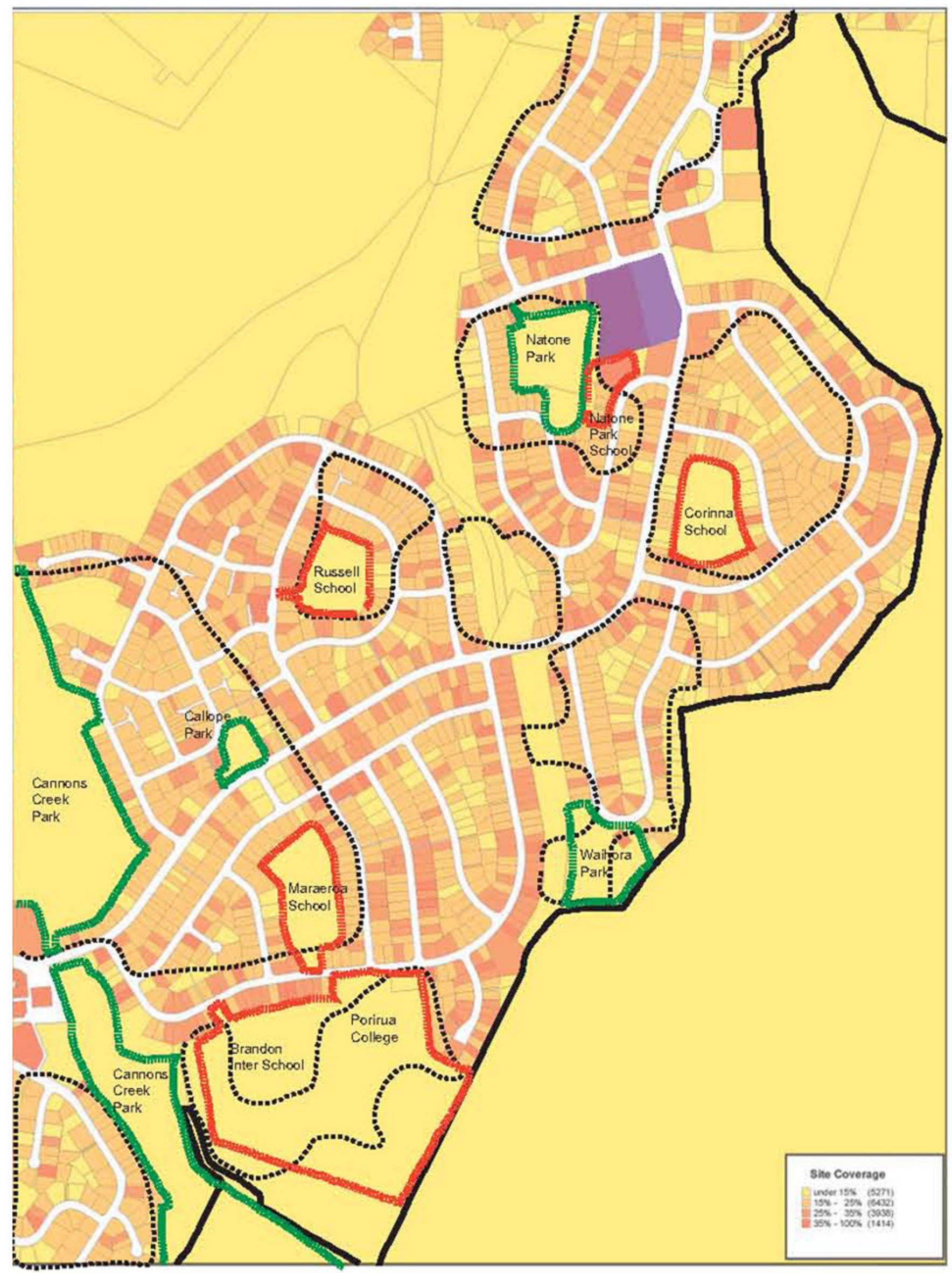

Figure 3.5 Site Coverage Map: Waitangirua. Boffa Miskell Ltd and Graeme McLindoe Architect \& Urban Designer, "Appendix Four: Slope Analysis and Site Coverage Maps", Porirua Suburban Character Study, (Porirua: Porirua City Council, 2005), 64 

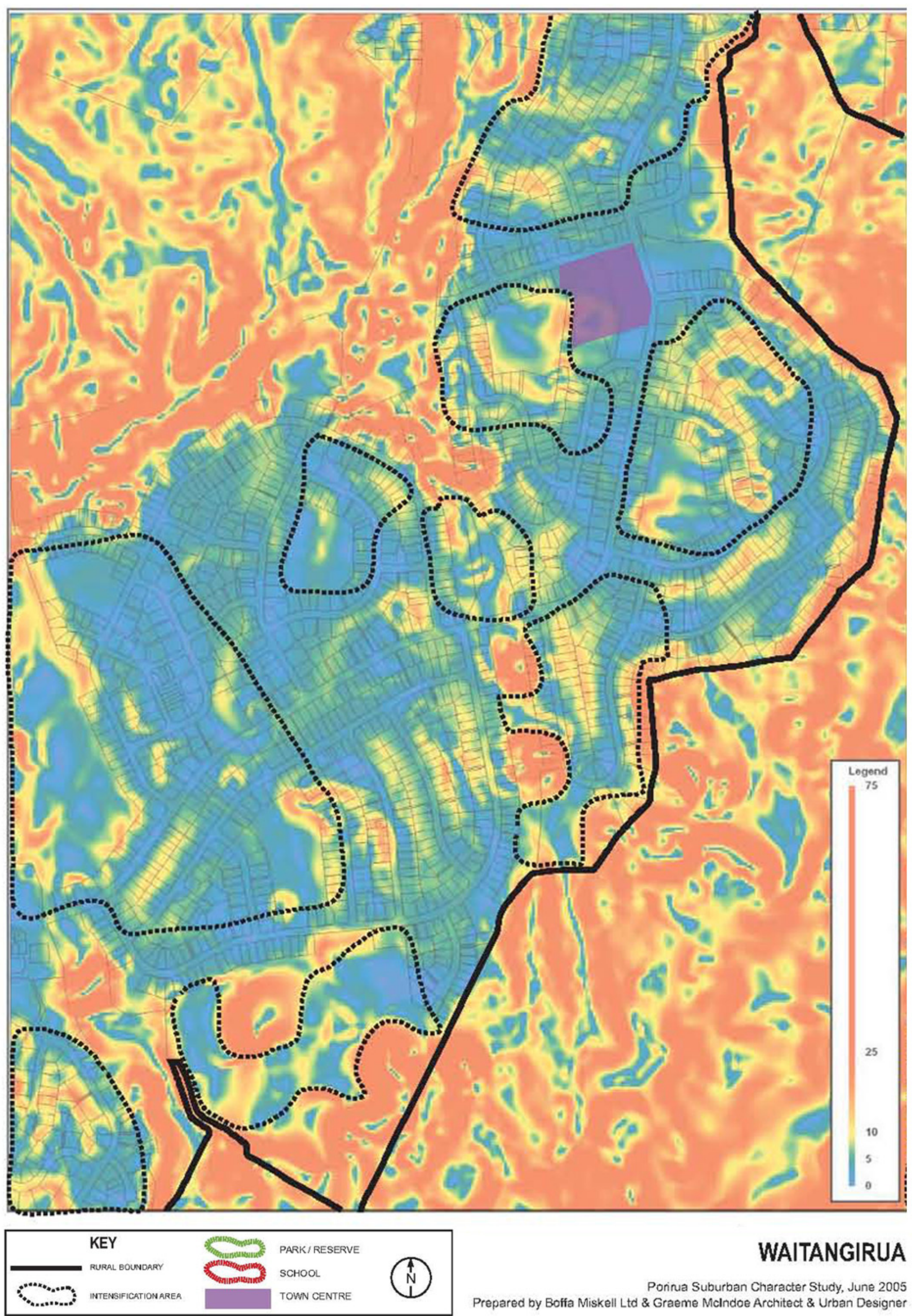

WAITANGIRUA

Porina Suburban Character Study, June 2005 Prepared by Boffa Miskell Ltd \& Graeme McIndoe Architect \& Urban Designer

Figure 3.6 Slope Analysis: Waitangirua. Boffa Miskell Ltd and Graeme McLindoe Architect \& Urban Designer, "Appendix Four: Slope Analysis and Site Coverage Maps", Porirua Suburban Character Study, (Porirua: Porirua City Council, 2005), 64 


\section{Lived Space and the Performative in Porirua East}

A more in-depth perspective of Eastern Porirua's social environment is evident in documents from Housing New Zealand Corporation's Community Renewal Programme (2000 to 2008). This programme was developed to "address social exclusion, foster strong, sustainable communities, and promote change in the economic, social and physical environment in selected areas." 104 The tasks undertaken included maintenance and renovation of Housing New Zealand's state rental stock through street makeovers, graffiti removal, improving road safety, community facility development, and the creation of community events such as People and Places: An Eastside Story in 2003.

People and Places focused on residents' own stories and perceptions regarding their lives within their immediate living environment, and documented the interaction of residents with the built environment of Eastern Porirua through resident interviews, photography and other artwork. The project was described by co-ordinator Warren Jones as a "bold exercise in community investment" that "offers insights in to a community that is richly diverse and interesting, possesses levels of community pride and spirit that in a sense confounds the general negative perception of the area known as Eastern Porirua." 105

The project culminated with (a) a curated exhibition of a series of black and white photographs that showed residents in the context of their daily lives, (b) a documentary film conveying shared experiences and values from interviews of past and present residents and professionals who worked within the area, (c) a storytelling festival, and (d) a community vision exercise. ${ }^{106}$ The photographic exhibition included historical and wider contextual images that highlighted significant places and events from the area such as the visit from Queen Elizabeth and the Duke of Edinburgh in 1963, the Maraeroa urban marae, street protests, the areas first convenience stores and the moving of the Bottom Tavern in 1973 (Fig.3.7-3.8).

Similar to the People and Places photographic exhibition is the 2005 photographic essay Eastside: A contemporary view of Eastern Porirua, by Wellingtonian Jonathan Aitken, which documented everyday life within contemporary Eastern Porirua. The essay conveys an intimate connection between people and their surrounding environments, such as local sports fields, school playgrounds, the local market, church and mosque as well as an active engagement with the architectural structure of the State Houses that densely populate the area. For example, one photograph displays the use of an umu in the backyard, while others document the erection of a lean-to add-on structure to the entrance of a house, a goat tied to the side of a building, the digging of trenches and foundations, and a fence trellising detailed with Pacific-style carving (Fig.3.9-3.10).

Additionally, the documentary film from People and Places, documents an engagement, and often conflict, with what some feel was a built environment that was imposed upon them, and a realisation of the colonial and political influence the government exerted within the area. Joe Te Pania for example, observed that:

This whole Waitangirua area here, all the streets here are named after Union Steamship Company boats, the Karina, Karina Street, Niagra, the ship Niagra. Then when you get up the road a bit further they're called after racehorses, racetracks, Ascot Park. So this whole area is significant to its colonial past ... I thought it was great when these streets were named and it was launched, by one of the ... at the time I think a person came from the Union Steamship Company to launch the whole naming of these streets around this area. Natone, the street that I lived in, that was a ship, a Union Company trading ship. And so ... it is, we do live in a very unique area. I think what we should do with these streets is put a waka name below them, or above it, and say well you know these are the original traders of the Pacific were these wakas, the names of these wakas, but no that's just me again (laughs), thinking outside of the norm. [laughs] ${ }^{107}$

Journalist and creator of Te Awiti, the local community bulletin, Don Polly echoes this sentiment stating "In Cannons Creek alone for example, they have some 66 different streets in that community and not one of them has a Māori and Polynesian name." 108

104 Housing New Zealand Corporation, “Community Renewal Programme Evaluation”

105 Jones, Warren, 3

106 Jones, Warren, 7

107 Te Pania, Joe, in Housing New Zealand Corporation, People and Places: An Eastside story [documentary film]

108 Polly, Don, in Housing New Zealand Corporation, People and Places: An Eastside story [documentary film] 

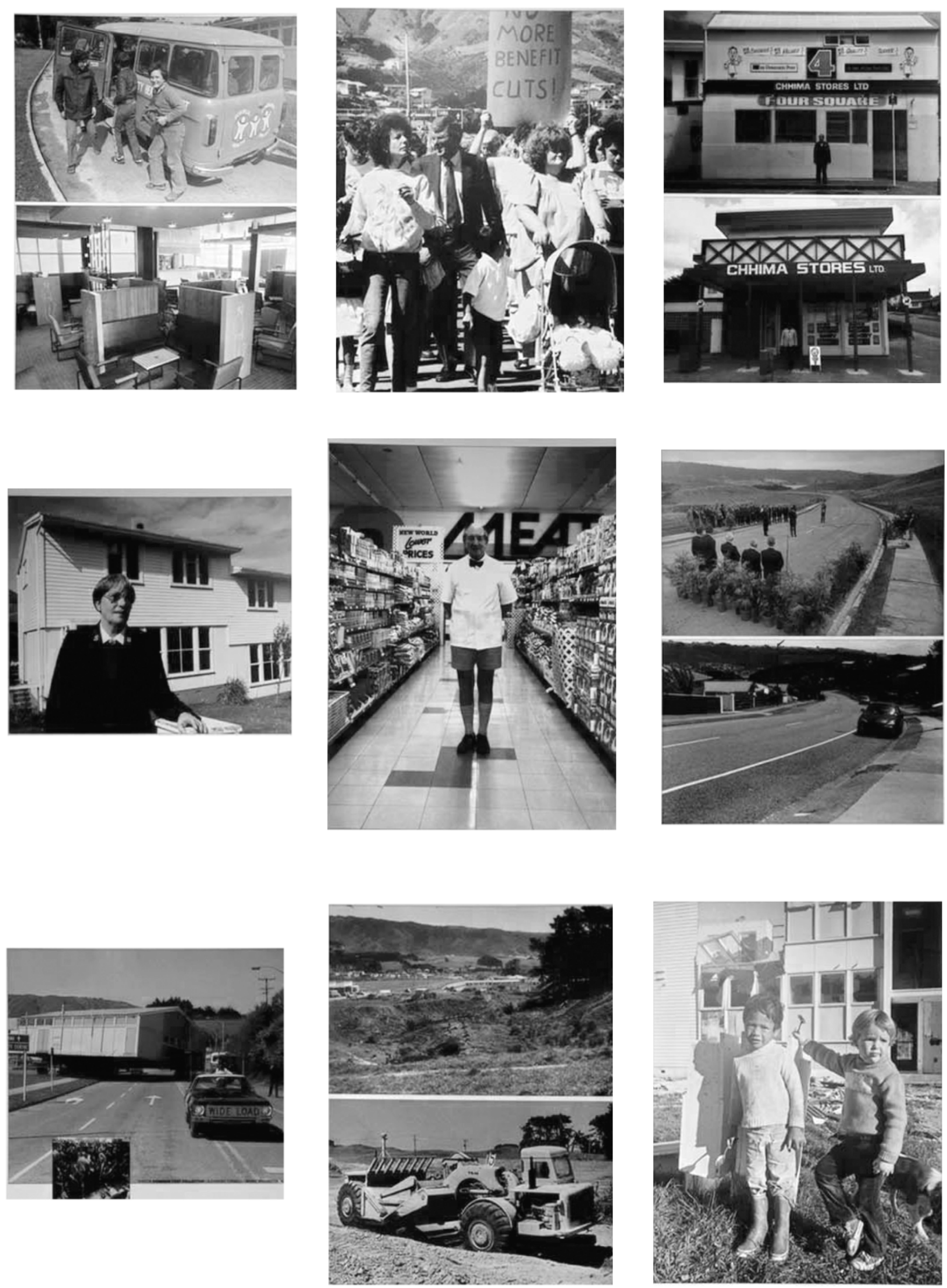

Figure 3.7 Assorted Images from the People and Places: An Eastside Story photographic exhibition currently on display at Keneperu Hospital, Porirua [1]. The images convey significant areas and events from within Eastern Porirua, such as the moving of the bottom tavern (Bottom left), the area's first four square supermarket and general store (top right), a protest against benefit cuts in the 1990s (top middle), and the demolishing of a small number of multi units within the area in the late twentieth century (bottom right). 

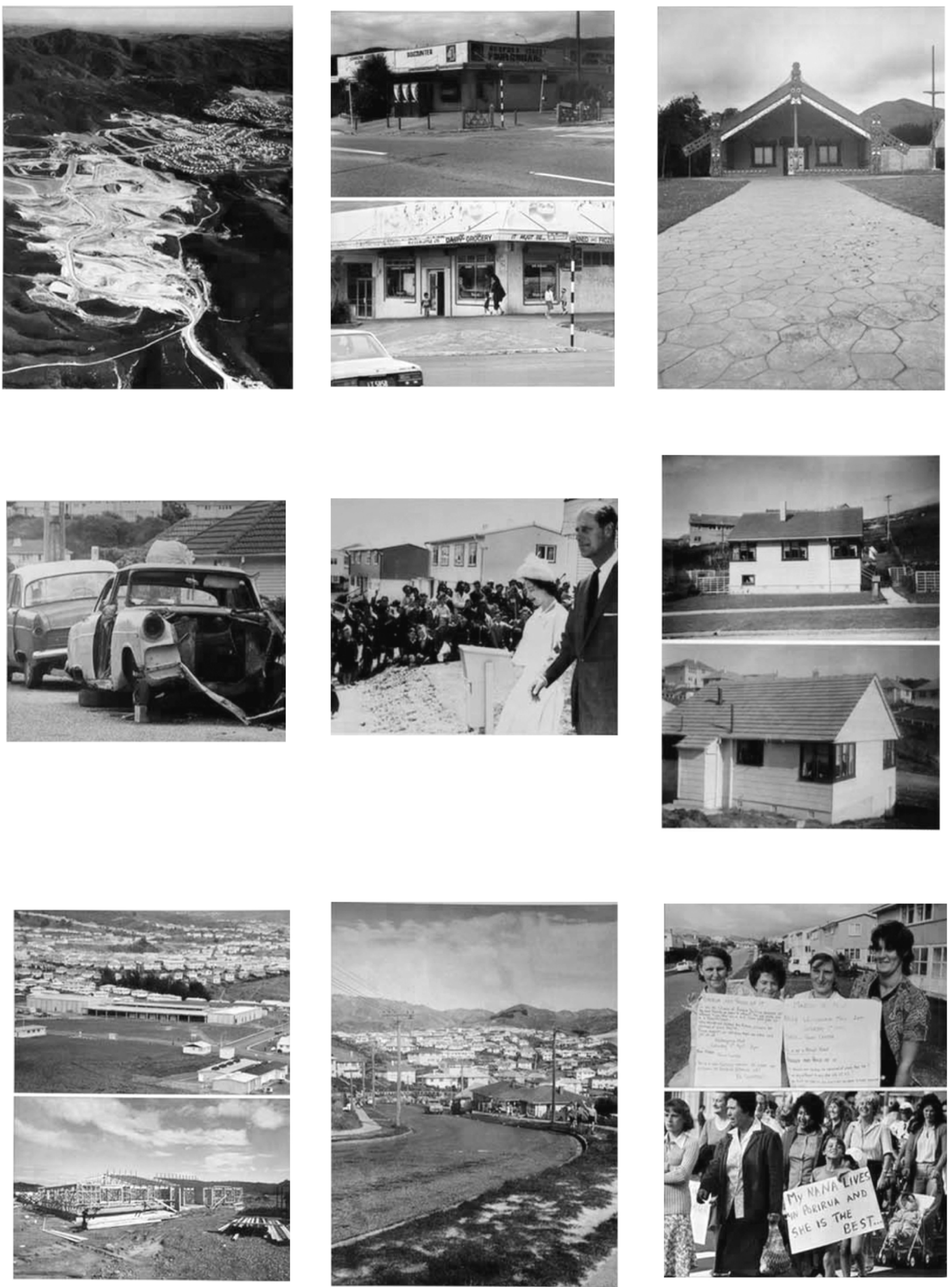

Figure 3.8 Assorted Images from the People and Places: An Eastside Story photographic exhibition currently on display at Keneperu Hospital, Porirua [2]. The images convey significant areas and events from within Eastern Porirua, such as the Maraeroa Urban Marae (top right), and the visit of Queen Elizabeth and the Duke of Edinburgh in 1963. 
Joshua Blandford. Possibilities Towards a Post-Colonial Architecture in Residential New Zealand
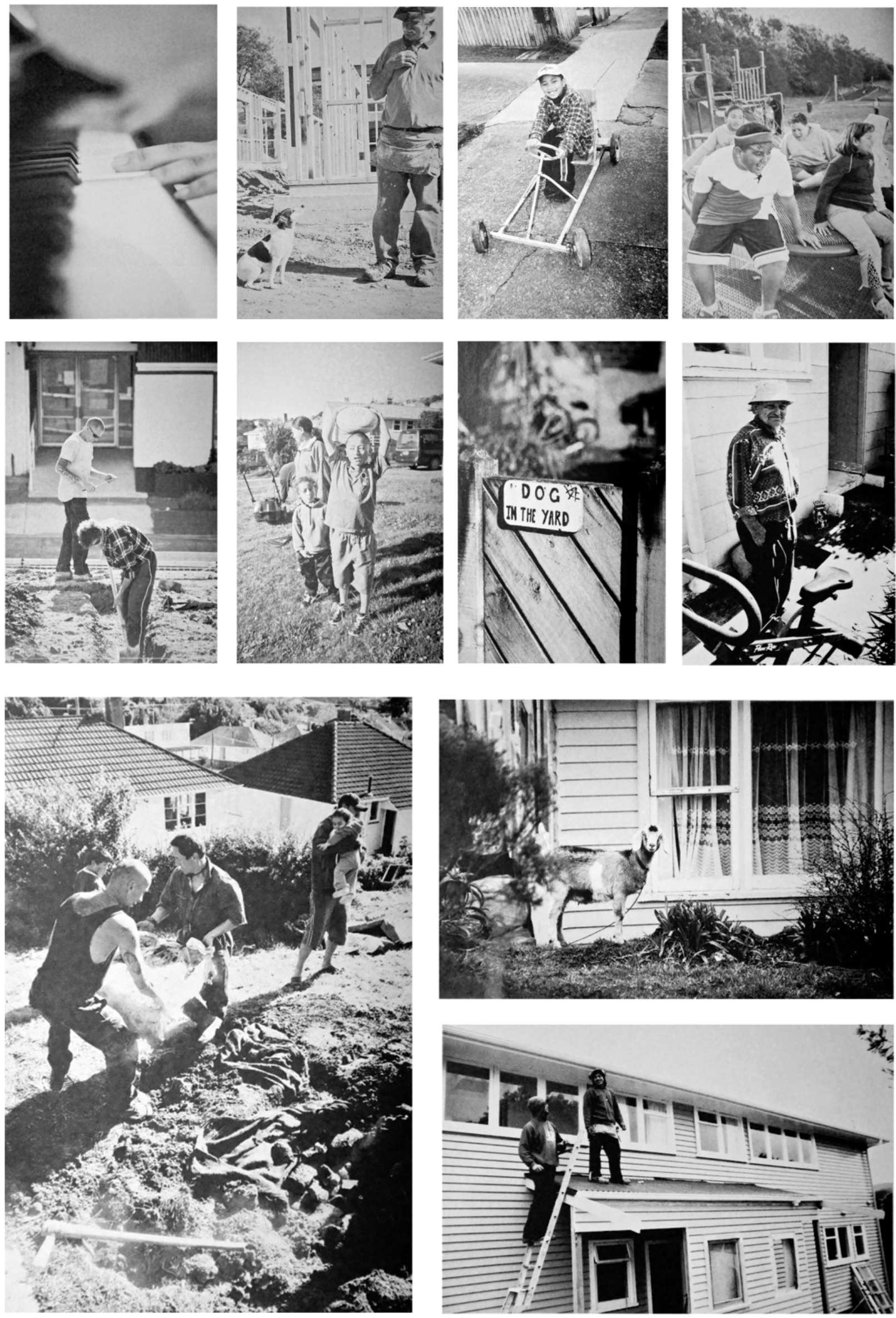

Figure 3.9 Assorted Images from Aitken, Jonathan, Eastside: A contemporary view of Eastern Porirua [1]. The images display intimate snippets of everyday life in Eastern Porirua such as the construction of and umu (bottom left), children playing at the local park (top right), and a hand resting on the keys of a piano (top left). 

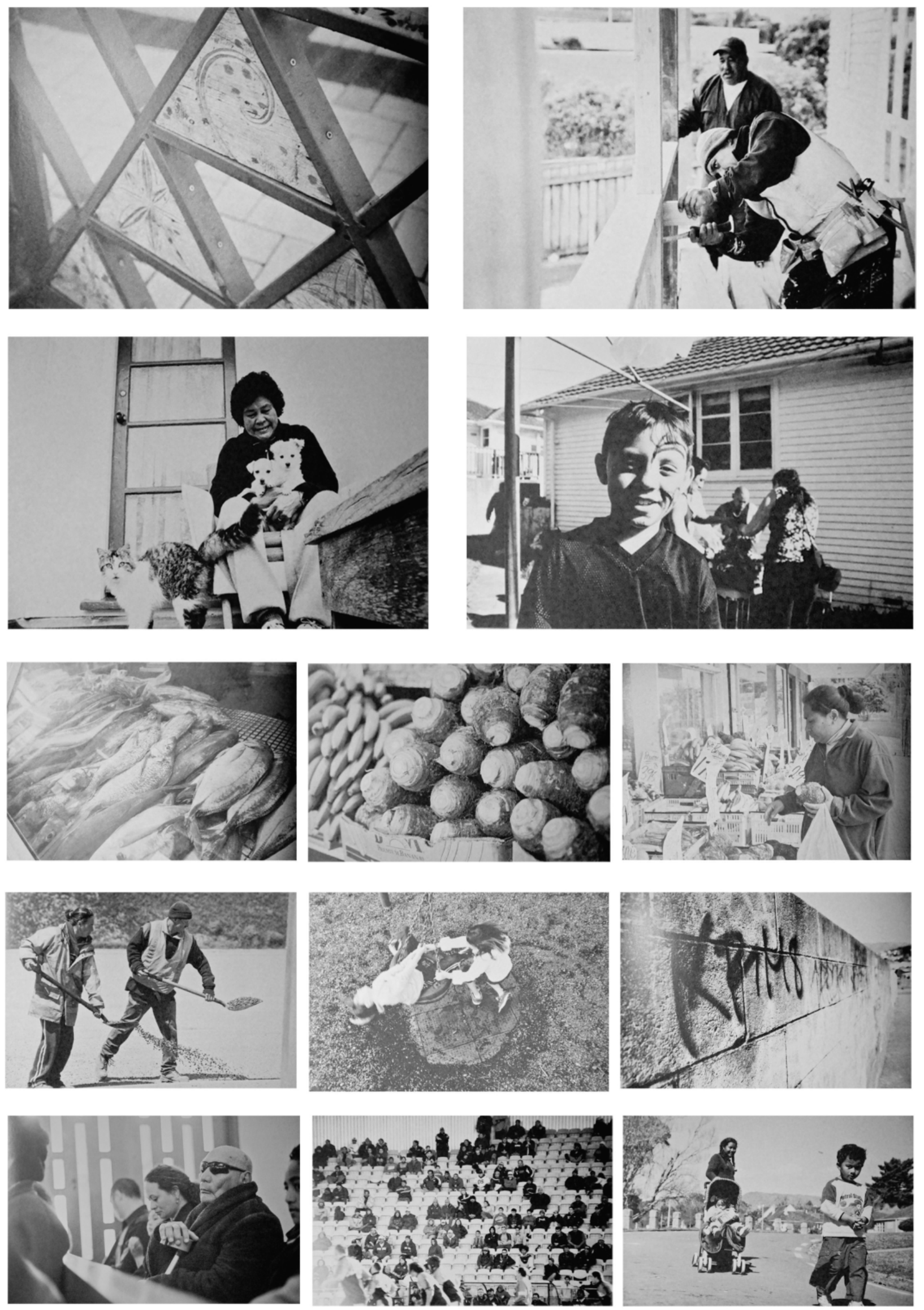

Figure 3.10 Assorted Images from Aitken, Jonathan, Eastside: A contemporary view of Eastern Porirua [2]. The images display intimate snippets of everyday life in Eastern Porirua such as the crowd at the local rugby match (bottom middle), graffiti on a concrete block wall (bottom-centre, right), the local church service (bottom left), and a Pacific style fence trellis (top left). 
For many of the residents, Eastern Porirua was the place through which they acclimatised to 'New Zealand' life. Rima Mataa told his story:

When I came over, in 1965, I couldn't sit down and have a conversation. I wouldn't even agree for an interview because of a lack of English you know.... It was cold, and I had summer clothes on. But luckily my mum and my sister came with an overcoat, one of dad's overcoats. But I had sandals, no socks, no one, the family never explained you better bring this bring that bring some warm clothes, because I hopped on the boat in summer-ware, you know that's all I knew, was summer! And I think it took me about three years to slowly acclimatise myself to the weather over here and, the nightlife, the nightlife is very good here. But that's another story. [laughs] ${ }^{109}$

In addition to acclimatising to the New Zealand environment, Māori and Pacific Islanders often faced institutional and social racism:

Attitudes, attitudes in terms of how some of the people were treated in Porirua East, attitudes when you went to the department to apply for housing, transfers, the way you were treated, and I think it was also very racist. In my mind, I have no compunction about saying that because we had a hui over this problem later on, after I'd left there. They were very discriminating. They were also very much about, this was a poor place, and therefore they didn't require attention. They didn't treat certain people like that. It was just those that were solo or underprivileged or whatever. And so I believe that they were extremely difficult people to work with in those days. Housing was a very serious problem, in terms of getting housing, property. It was not seen as something that you should have as a right, it was a privilege. ${ }^{110}$

Porirua's location, lack of facilities, social housing policies and institutional discrimination caused a type of segregation for many in Porirua, forcing an internal interaction and development within the community and against the uniformity of the "row after row of state housing". At the same time, state housing residents were severely limited in terms of the renovations they could make to their properties, and State Houses within Eastern Porirua that are now privately owned display greater change.

In order to support the empirical evidence generated in People and Places, a street elevation image study was undertaken to gauge the scope and scale of change enacted within the area (Fig.3.11-3.12). This involved collecting street elevations of approximately 100 houses within two areas of Cannons Creek, and investigating the presence of recurring changes or characteristics within the elevations. The areas were chosen due to their high number of state rental houses, and classification as deprived. The most recognisable change identified through the study is the diverse array of fences that line the street frontage and clash with the monotony of the houses behind them. Another easily identified change is the erection of carports or garages on many of the sites, not all of which are used as spaces to park cars. The placement of some fences, driveways and parked cars also suggest that the rear entrance to the house is often used as the main entrance, conveying a reversal of the entrance to the houses and the possibility that the front yard is used as a backyard space and vice versa.

109 Mataa, Rima, in Housing New Zealand Corporation, People and Places: An Eastside story [documentary film]

Sister Veronica shared a similar experience: When I came to New Zealand first, I didn't know how to dress myself for the climate. Because you know the people wear very simple clothes on the island. And I didn't know how to dress the children. So then we started a sewing class. Then another mother said, I don't know how to cook the food in New Zealand, and may be eating all the wrong food, which some of them did because they liked fish and chips and cream buns and things like that which aren't very good. Veronica, S. in Housing New Zealand Corporation, People and Places: An Eastside story [documentary film]

110 Shaw, Jane, in Housing New Zealand Corporation, People and Places: An Eastside story [documentary film] 

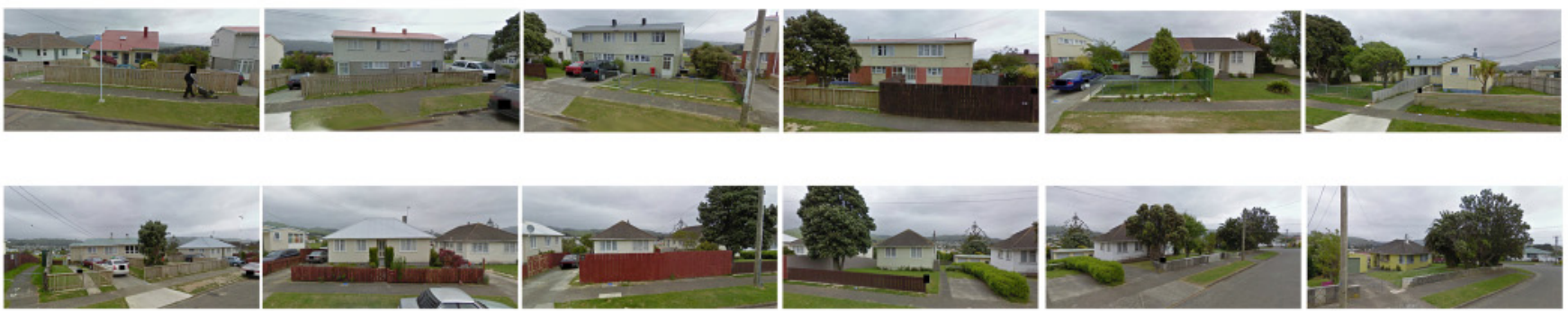

Miranda Street looking West
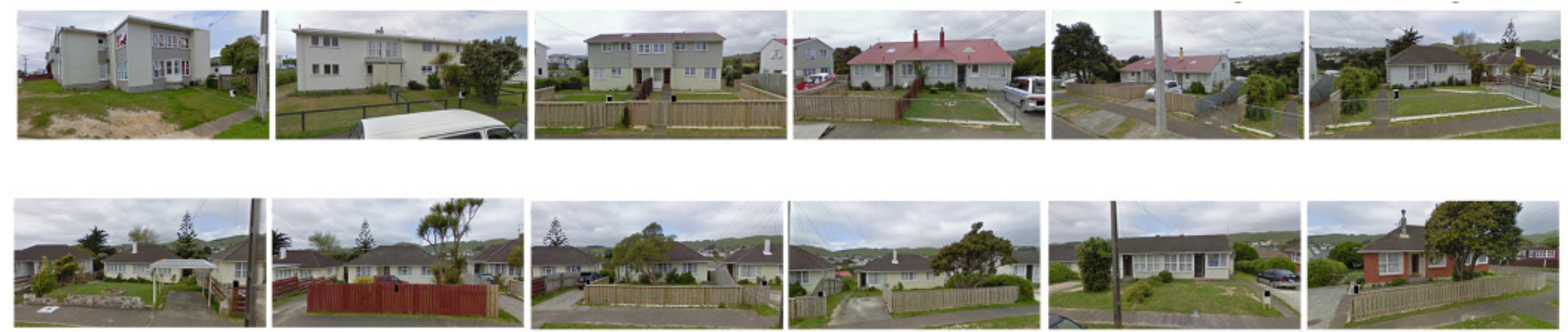

Miranda Street looking North then East
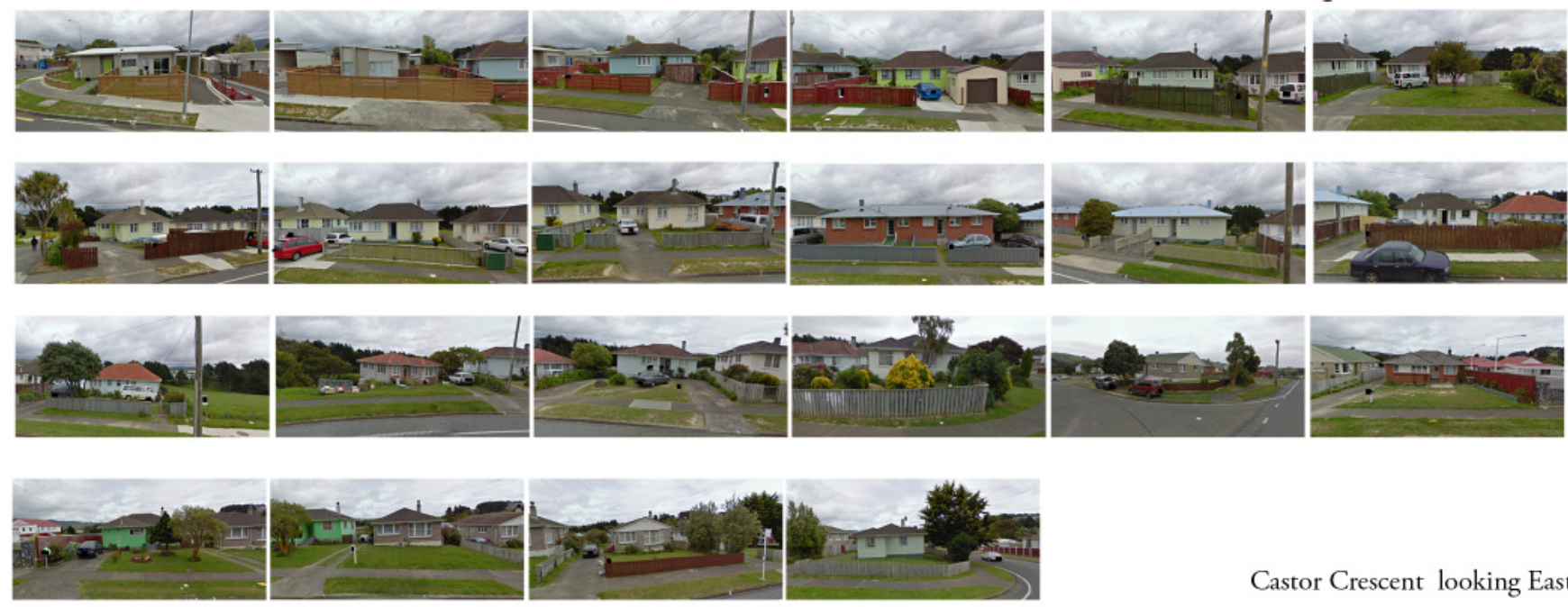

Castor Crescent looking East
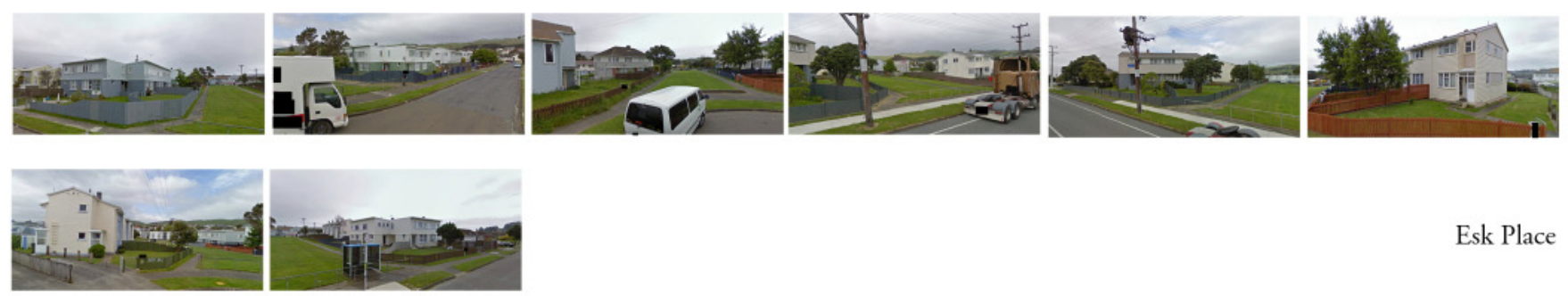

Esk Place
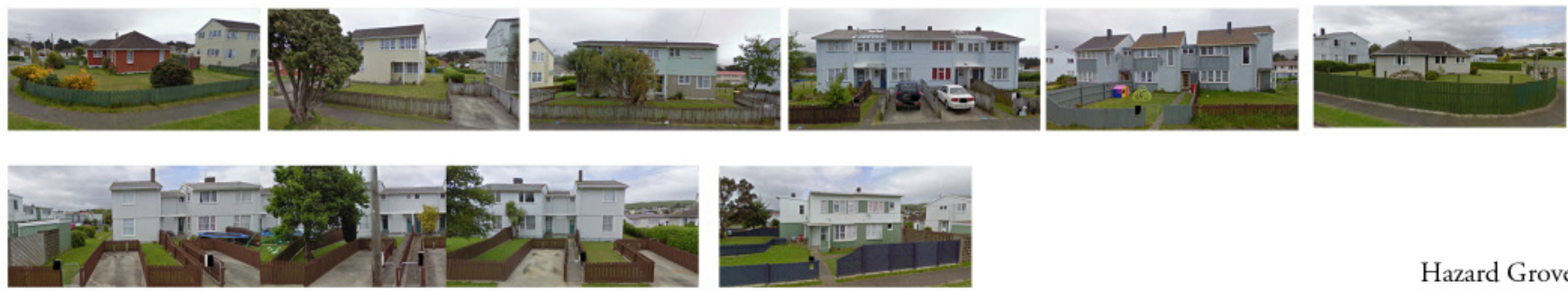

Hazard Grove

Figure 3.11 Street Elevation Images from Cannons Creek, Porirua [1]. Each image depicts one house, with the houses to the left and right being the neighbouring properties. The elevations convey the prevalence of fencing between the houses and the street that has been added since its initial development, and the erection of carports and garages. Important to note is that many of the properties that have erected carports and garages have parked cars on the front lawn of the property, rather than within the carport/garage, suggesting they serve other uses. 


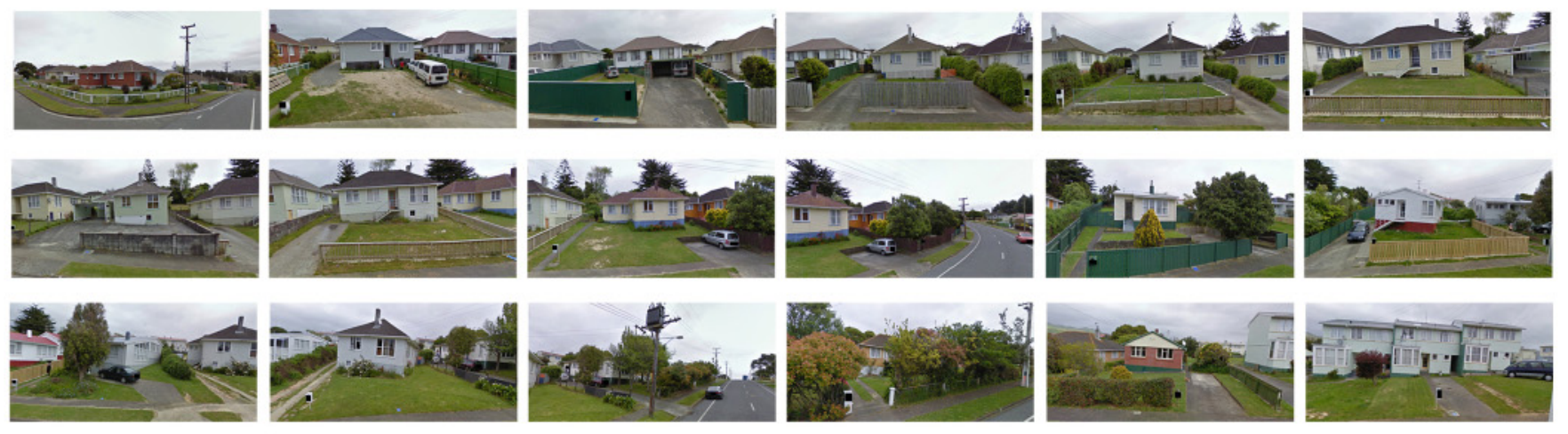

Upper Castor Crescent looking West
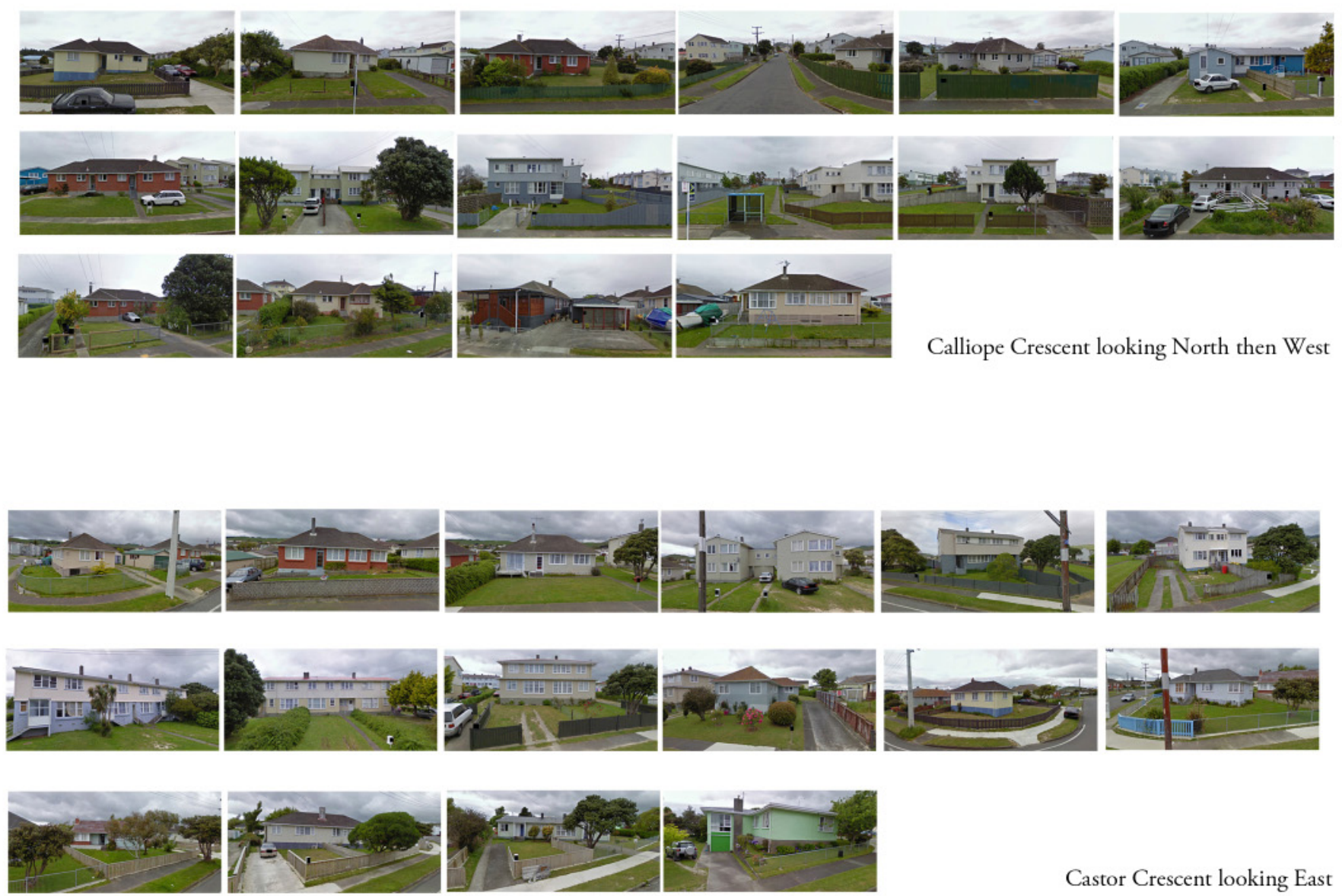

Castor Crescent looking East
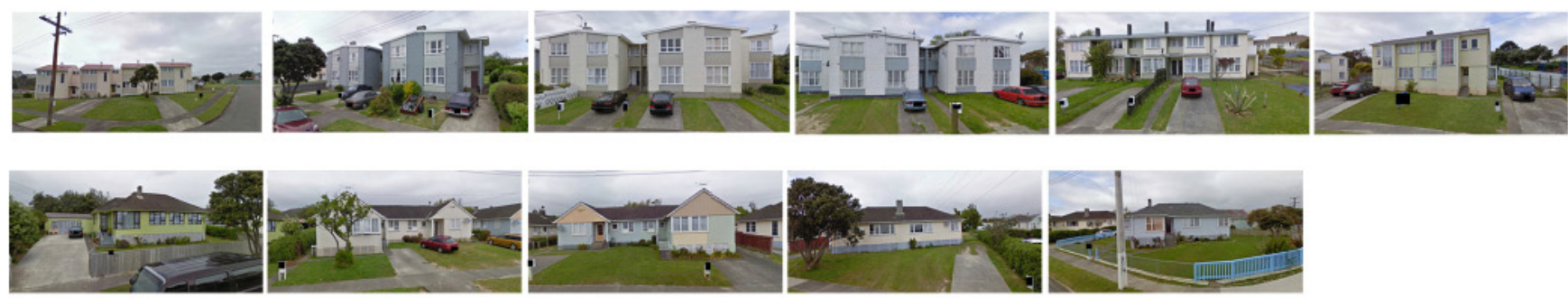

Calliope Crescent loking East then South
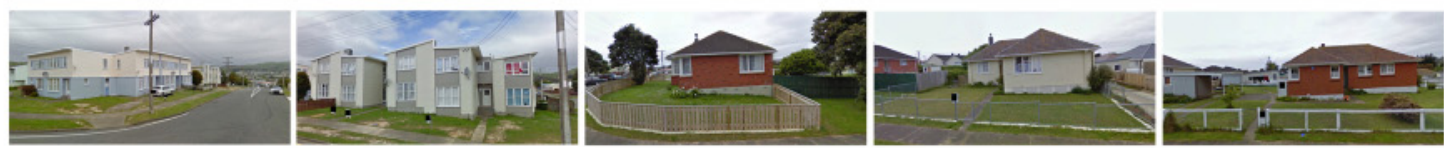

Figure 3.12 Street Elevation Images from Cannons Creek, Porirua [2].

Fantame Street and Niger Street looking North 
Analysis of the documentation of the Housing New Zealand Community Renewal Programme and the street elevation study produced five persistent themes regarding the architectural and social space evident in Porirua East. These were:

- Providing a clear distinction and emphasis between the front fence as a barrier between the house and the street

- Establishing sheltered outside areas to accommodate social and communal gatherings similar to those often held within garages

- Establishing areas of possible extension and/or alteration to allow flexibility of use and appropriation of the space by the inhabitants

- Allowing for the possible practice of spatial practices other than those immediately associated with the domestic house (i.e. hangi, tangi etc.)

- Conveying the cultural diversity of people within the area through naming, surface and material treatments, and ornamentation.

These criteria will be used to develop the design outcomes presented in Chapter five alongside the concepts developed within the design experiments in the following chapter. 



\section{CHAPTER CONCEPTUAL EXPERIMENTATION}

FINDING A POST-COLONIAL ARCHITECTURE THROUGH CULTURAL NARRATIVES

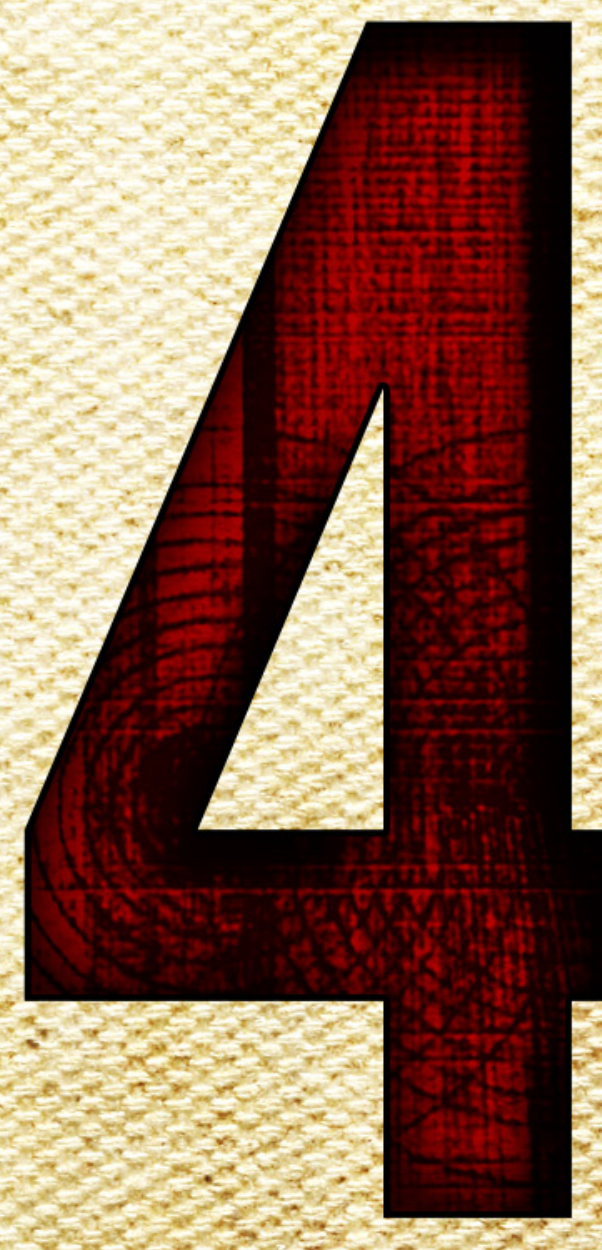




\section{Chapter Four: Finding a Post-colonial Architecture through Cultural Narratives}

This chapter provides two design experiments that express previously suppressed cultural narratives of space in order to challenge and critique the dominant and homogenous narratives of colonial space. Each design experiment uses one Māori narrative to critique one colonial narrative. The first experiment uses the architecture of the wharenui to challenge the dominant mechanisms of architectural representation, whereas the second uses the Mãori concept of tapu and noa to challenge the architecture of the State House. In other words the first experiment reads a Mãori narrative through a colonial mechanism, and the second reads a colonial narrative through a Māori concept. ${ }^{111}$ The narratives of the wharenui and tapu and noa will first be introduced in section one, then the design experiments that use these narratives will be described and analysed in section two.

\section{Section One: Introduction to Māori Cultural Narratives and Concepts}

\section{Introduction to the Wharenui/Marae}

The wharenui and marae are principal typologies to Māori and a strong identifier of Māori culture, spirit, and mana. ${ }^{12}$ The term marae can refer to the marae àtea, the area in front of the wharenui, but also can refer to the marae complex as a whole, the combination of the marae àtea with a set of communal buildings that includes the wharenui (Fig.4.1-4.2). ${ }^{113} \mathrm{~A}$ marae must have a wharenui in order to operate, and explicit references to marae are therefore implicit references to wharenui, and vice versa. ${ }^{114}$ Kerr clarifies the link between the wharenui/marae and home for Māori:

To many of us that hall [wharenui] means home. When we were kids we used to love sleeping in the hall, and now my mokopuna love going to stay, too. Everything that we're about is symbolised in that hall. It is the glue that holds us all together. ${ }^{115}$

The marae is our bond with the land and or whakapapa [genealogy]. Some afternoons, I go and sit there and I can remember all the old people that sat there before me, their photos still hang on the marae walls. ${ }^{116}$

I get real comfort from our marae. The weddings, taki auē, Māori netball, tug-o-war, Hui, cards, action song practices and fights are all imprinted in the walls. We would lose all of that if we replaced our hall. ${ }^{117}$

Traditionally, wharenui are the symbolic centre of an iwi or hapū, its architecture displaying its genealogical history in numerous ways, ${ }^{118}$ perhaps the most influential of which is in its figuring of the body of a tribal ancestor in its structure. As Hancock describes:

The ridgepole (tahu) is the backbone, ending in a mask (koruru) at the front of the house, sometimes with a full figure (tekoteko) above it. This mask is the head of the ancestor, and the front window (mataaho), the eye. The bargeboards (maihi) are the arms ending in fingers (raparapa). The maihi and their vertical supports (amo) were often completely carved, and the raparapa often had pierced carving. The porch (whakamahau) is the brains (roro) and the inside of the house is the belly (poho). Rafters (heke) and side wall slabs (pou) are the ribs. Over the door is a lintel (korupe), the most important element in the transition from outside to inside (entering the body of the ancestor) (Fig.4.3-4.4) ${ }^{119}$

111 For reasons of scope the narratives utilised within this chapter are limited to the wharenui and the socio-spatial concept of tapu and noa. The experiment method could be repeated, however, with other architectural typologies and cultural socio-spatial concepts.

112 Linzey, 13-19, see also Walker, "Mana and Identity", 4-9

113 Austin, "A Description of the Māori Marae", 232

114 Austin, "A Description of the Māori Marae", 232, 236-237

115 Kerr, 12

116 Kerr, $12-13$

117 Kerr, 13

118 Hancock, $1217-1218$

119 Hancock, 1218 
Figure 4.1 Diagram of the Māori Marae. This diagram by Mike Austin shows the conventional orientation and relationship between the wharenui, the marae atea, and the landscape.
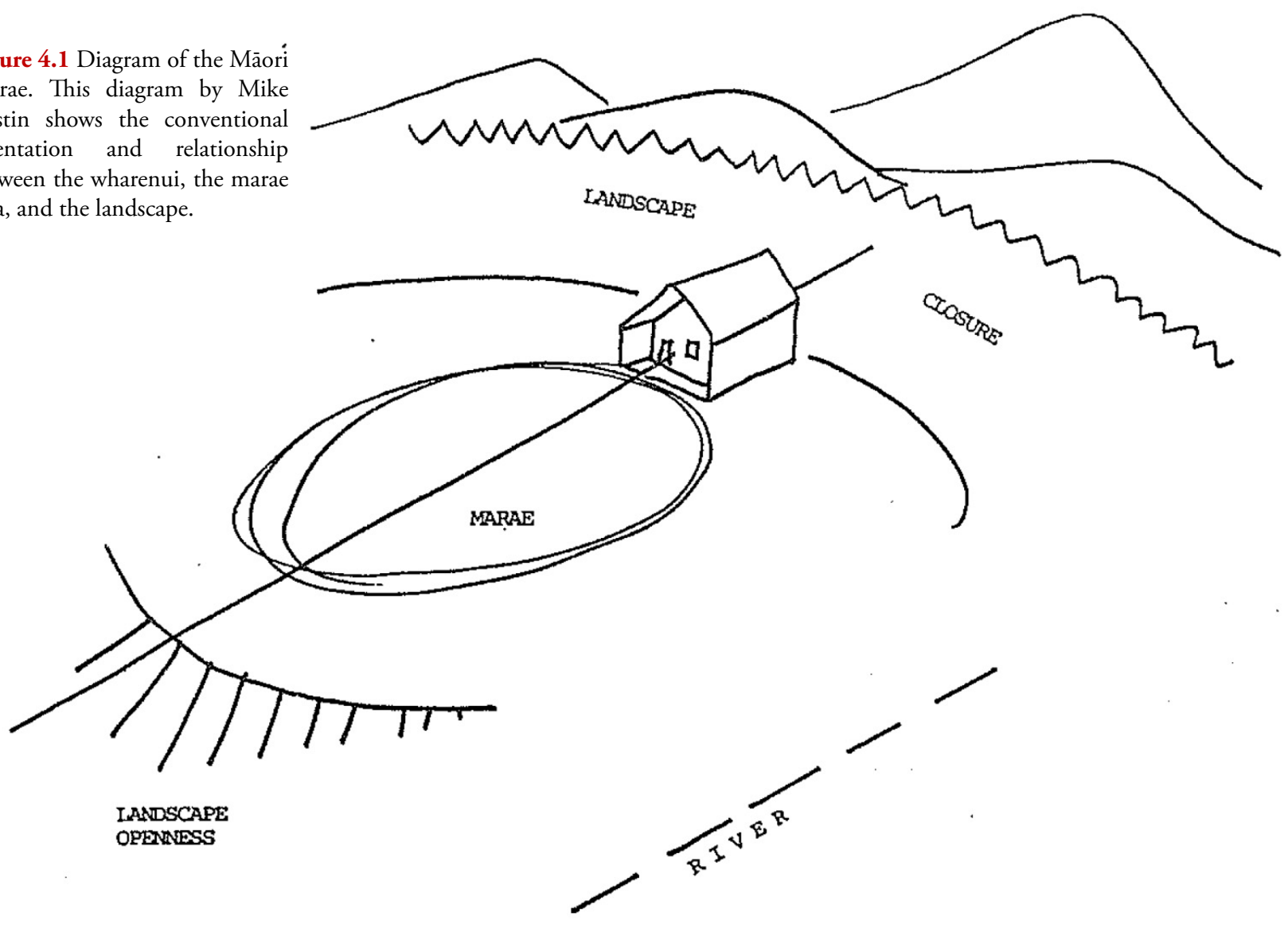

Figure 4.2 Diagram of the Buildings Within the Māori Marae. This diagram, also by Mike Austin, conveys a conventional Marae complex, showing the relationship between the central wharenui and marae atea to its surrounding buildings.
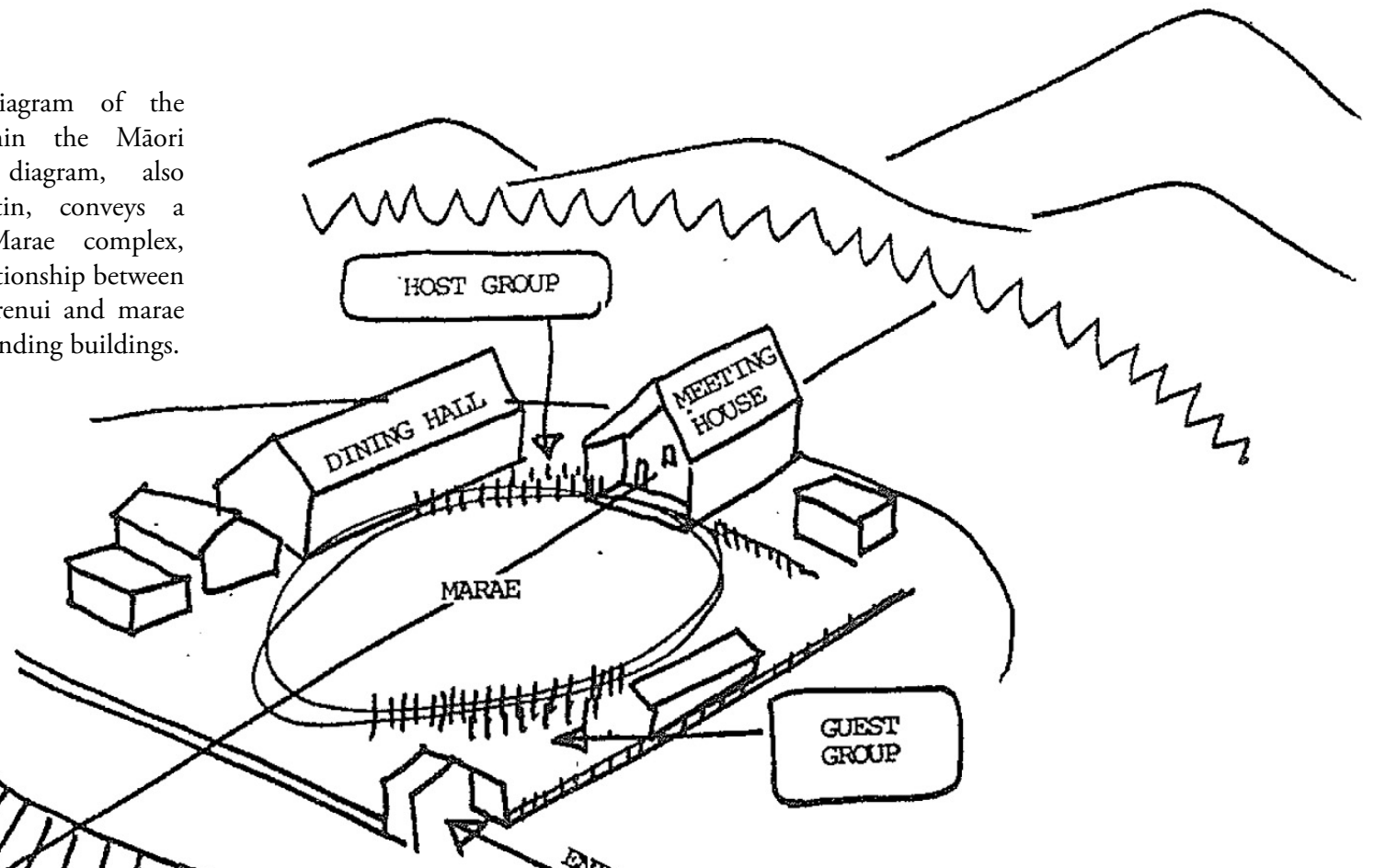
The wharenui is most often a unicellular gabled space with a porch containing one door and one window into the enclosed space (Fig.4.5). Although spatial distinction within the marae occurs, such as the space at the front of the marae near the door and window being reserved for people of high rank, these are not dictated through physical elements as they are in the State House. ${ }^{120}$ Elements within the wharenui such as the whakairo, pou, koruru, amo, and heke among others are elaborately ornamented through carving, weaving and painting and represent creation principals, the gods, and ancestral links. ${ }^{121}$

\section{Introduction to Tapu, Noa, and its Relation to Māori Life and the Wharenui}

Within the marae complex and the wharenui, functions are separated spatially as well as through social restrictions. ${ }^{122}$ These are characterised by extensions of tapu creating spaces that are relative to noa. There are generally accepted spatial relationships such as the front areas with public and communal functions being considered tapu, while the rear with the dining, cooking and services are noa. The wharenui is noa in relation to the marae atea, the most tapu space in the complex, and the marae complex as a whole is tapu in relation to the outside world. ${ }^{123}$

Austin interprets the marae (and the wharenui as the principal building within it) as an establishment of clear relationships between static and dynamic space composed using the oppositions of earth/sky and light/dark as they relate to Māori origin myths. ${ }^{124} \mathrm{He}$ argues that the:

Present-day world of the marae is the world of light, and the interior of the house [wharenui] the world of darkness, while Rangi and Papa are carved on the ridge pole in the interworld of the porch. It could be suggested that this myth [the myth of Rangi and Papa] is re-enacted in the marae complex and interestingly this is paralleled by the action that occurs in each realm. The marae [ātea] is the world of men exercising their human power, status, prestige, knowledge, ability, authority - these are at stake when a man speaks on the marae. By contrast the house is a realm of murmuring, plotting, and planning; and here anyone can raise questions and issues. ${ }^{125}$

Austin continues:

The dynamic space sequences of the marae [complex], from the entrance opening to the closure of action and struggle on the marae proper [ātea] into the almost total enclosure where one sleeps, relate directly to the daily cycle. By extension this sequence would be regarded as a life-cycle sequence from birth to death, and the important events of the marae are in fact life-cycle crises. ${ }^{126}$

This cycle is based around the notion that the world follows a daily cycle of light (Te Ao) and darkness (Te Po). ${ }^{127}$ The story of Rangi and Papa emphasises the shift between darkness to the world of light. ${ }^{128}$ This is mirrored in the wharenui, where the marae atea is considered as Te Aō Marama, the interior of the wharenui as Te Po, and the front porch and doorway a transition between the two worlds. ${ }^{129}$ It is clear then that the Māori world view and creation narratives are embedded within the architecture of the wharenui through spatial practices and qualities.

The generally accepted oppositions described above extend beyond the marae into the modern home through sources such as Hoskins' Māori housing guide Ki te Hau Kainga ${ }^{130}$. Ki te Hau Kainga extends from structuralist 1970s literature, which characterise tapu and noa as working within a structural framework that sees tapu and noa as ambivalent and oppositional terms. ${ }^{131}$ In contrast, Shirres' understanding of tapu extends from a series of Māori manuscripts, and forms the conclusion that:

120 Austin, "A Description of the Māori Marae", 237

121 Austin, "Māori", 1215-1216, also Hancock, 1218

122 Hancock, 1217-1218, also Austin, "A Description of the Māori Marae", 236-238

123 Hancock, 1217-1218

124 Austin, "A Description of the Māori Marae", 237

125 Austin, "A Description of the Māori Marae", 237

126 Austin, "A Description of the Māori Marae", 238

127 Te Ahukaramū, URL: http://www.TeAra.govt.nz/en/te-ao-marama-the-natural-world/3

128 Austin, "A Description of the Māori Marae", 238

129 Te Ahukaramū, URL: http://www.TeAra.govt.nz/en/te-ao-marama-the-natural-world/1/4

130 Rau Hoskins Design, 9

131 Salmond, 15, also Smith, 93, and Shirres, 29-30 

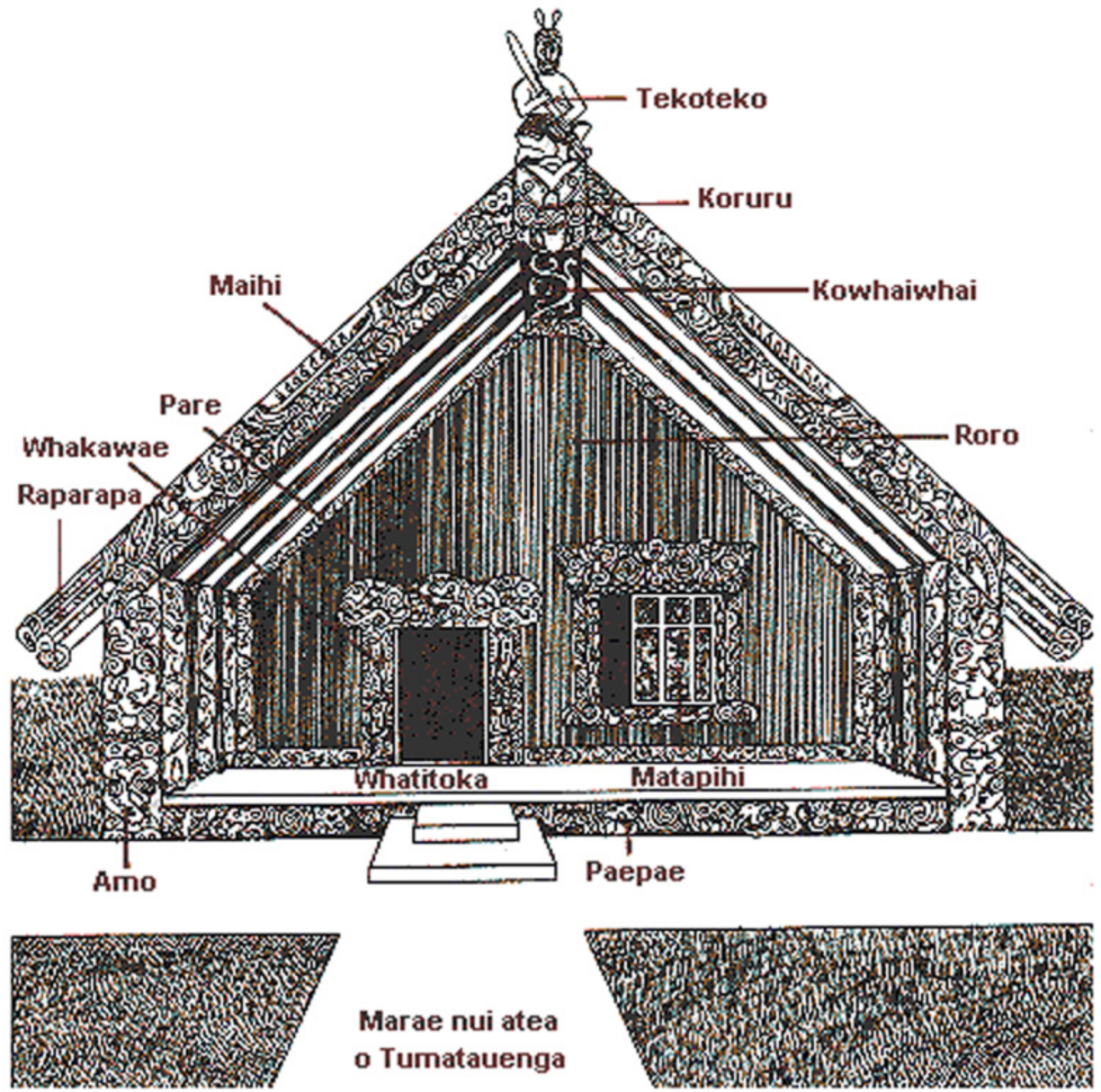

Marae nui atea

o Tumatauenga

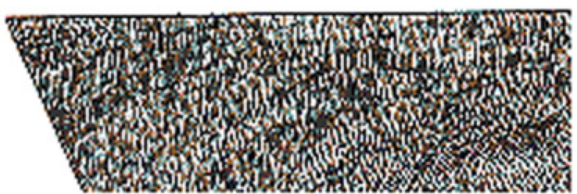

Figure 4.3 Illustrated diagram of the front elevation of a wharenui. This diagram shows the common elements and their names within the front face of wharenui.

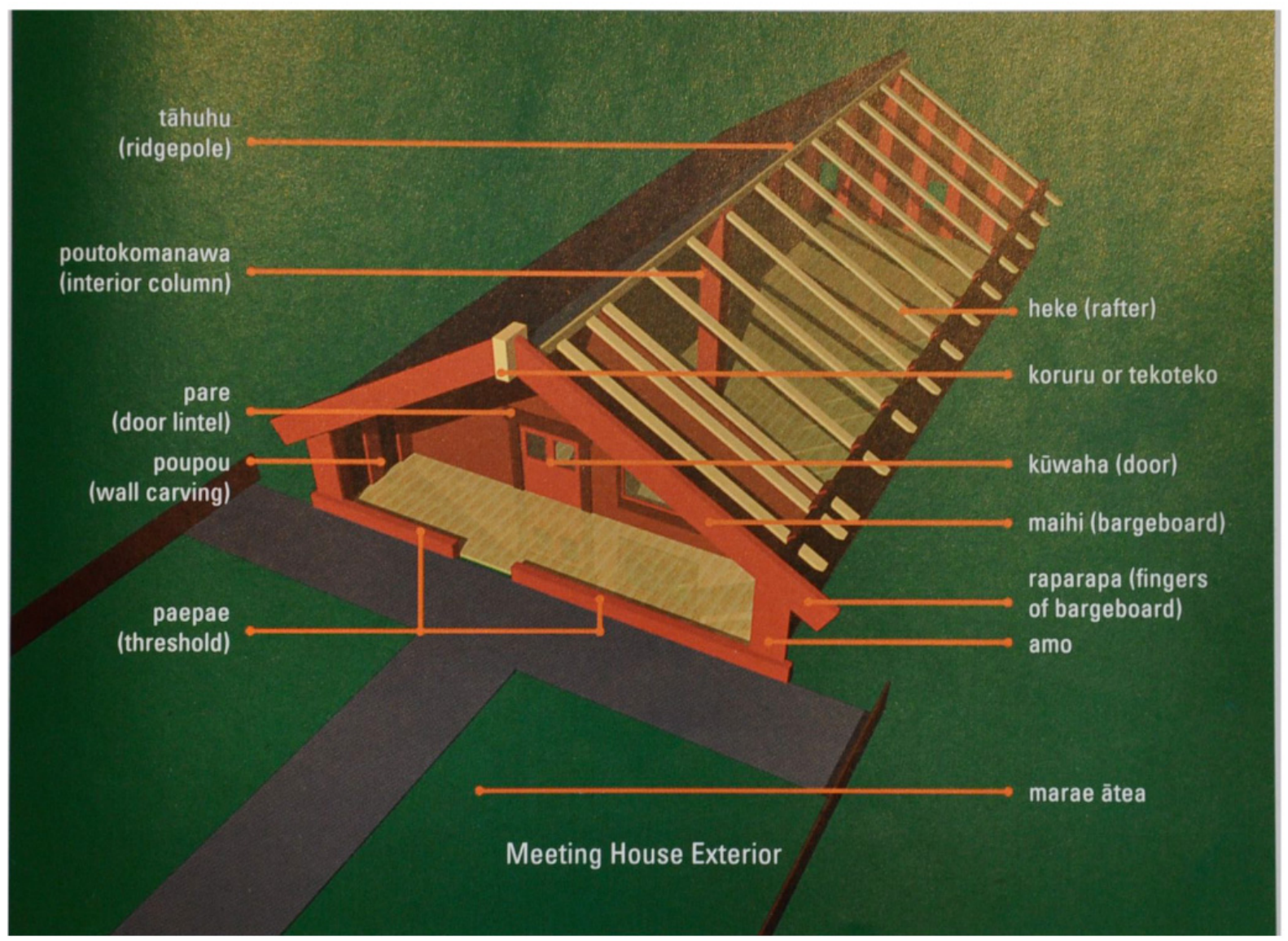

Figure 4.4 Diagram showing the generally used names of wharenui elements. 


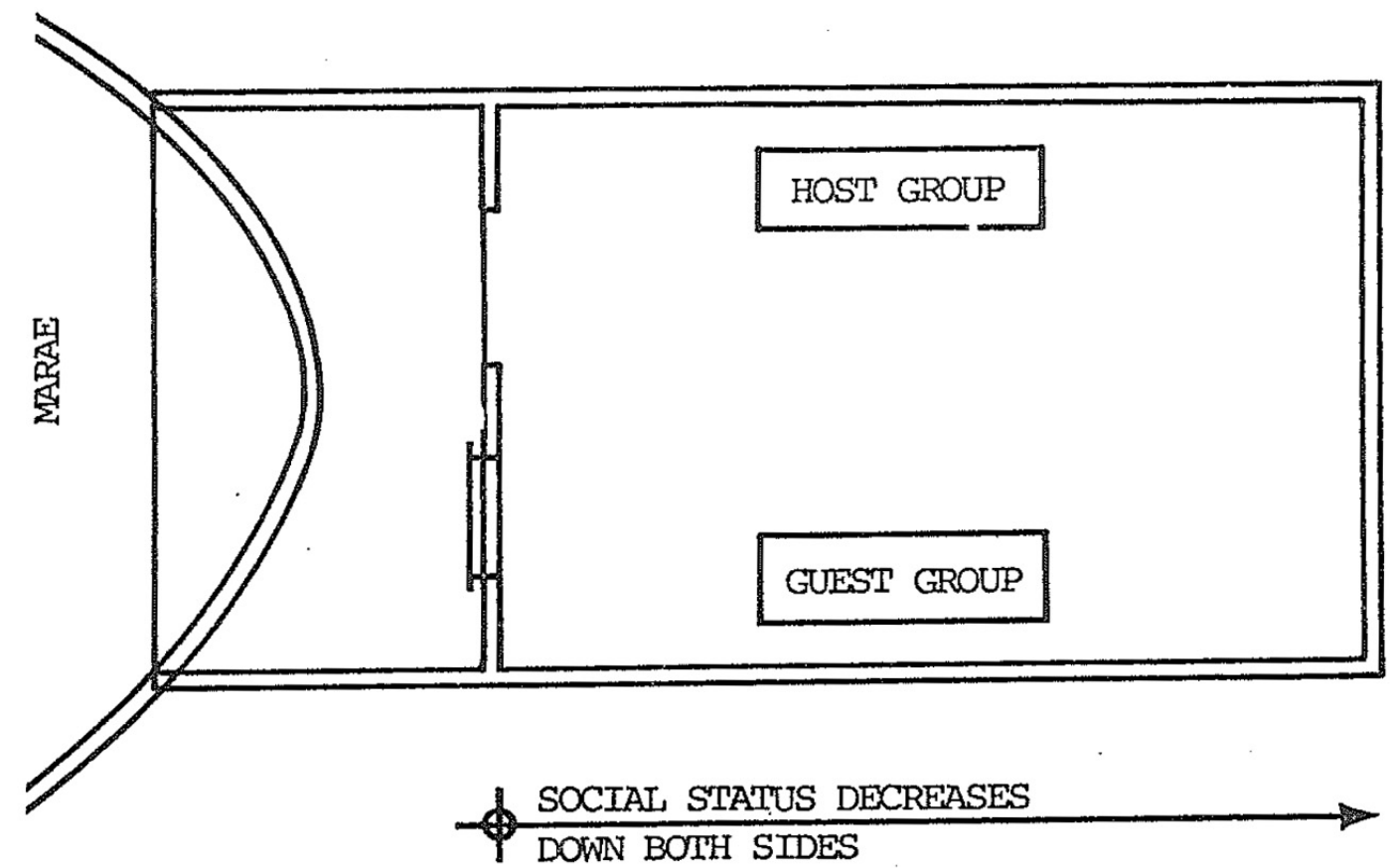

Figure 4.5 Plan of the Mãori Wharenui. This diagram conveys the socio-spatial distinctions that occur within the interior of the wharenui that are not signified by physical architectural elements.

tapu is not a univocal or equivocal term, but an analogical term. Tapu must be distinguished from extensions of tapu. While tapu in its extensions does include the notion of 'prohibition', the primary notion of tapu, linked to the notion of mana, is 'being with potentiality for power'. Noa is directly opposed, not to tapu itself, but to extensions of tapu. ${ }^{132}$

Rather than there being a single state or type of tapu in opposition to noa, Shirres argues that there are many different tapu:

Each of the children of Rangi and Papa are tapu. Individuals and groups of people are tapu; children, parents, war parties, sick and so on. Some of the tapu mark off places; houses, gardens and special ritual areas. Others mark off special times, so we have tapu days. There are tapu which need to be protected, strengthened and confirmed, for instance the tapu of the child. There are tapu which give protection, for instance the tapu of the iraamutu, the chief's sister's daughter. And all tapu can be seen as needing to be treated with respect, and sometimes fear, but this depends on which side you are on, on the relationship of your tapu to the other tapu. ${ }^{133}$

These different types of tapu extend from what Shirres categorises as primary sources of tapu, for which he argues there are two primary forms, the tapu of people and the tapu of the kumara. ${ }^{134}$ Several other tapu exist, and include both things and events, but all relate to either the tapu of people or the tapu of the kumara. ${ }^{135}$ Primary sources of tapu are intrinsic, "tapu in themselves ... each tapu in its own way, according to its own mode of being." ${ }^{136}$ Extensions of tapu, Shirres states, "can be properly understood only when they are related to the tapu of which they are extensions" (Fig.4.6). ${ }^{137}$

This interpretation of tapu and noa presents a more dynamic relationship, as clashes can occur between one intrinsic tapu and its extensions with another. For example:

At the planting and harvesting of the kumara, the tapu of the kumara, of Rongomaataane, must be reconciled with the tapu of man, the tapu of Tuu. A man's hands can become tapu either from the tapu of the kumara, at the planting and harvesting of the kumara, or from another person's tapu, for example at the haircutting ceremony. The resolving of this clash of tapu is the central concern of much, if not all, of Māori public ritual. ${ }^{138}$ 
This means that the significant clashes are to be found, not between tapu and noa, but between tapu and tapu. ${ }^{139}$ Noa in fact represents a resolution of conflicts in tapu:

Noa and intrinsic tapu go together. The child, on completion of his haircutting ceremonies, is noa and can go where he likes, not because his own intrinsic tapu is overcome, but because this tapu, the tapu of Tuu, is now fully strengthened and confirmed. ${ }^{140}$

Māori architecture and spatial practices are all related to intrinsic forms of tapu, which conflict with one another. These conflicts can then be resolved by the confirmation of one tapu over another, which creates a state of noa.

\section{TAPU}

\section{In Itself (Intrinsic Tapu)}

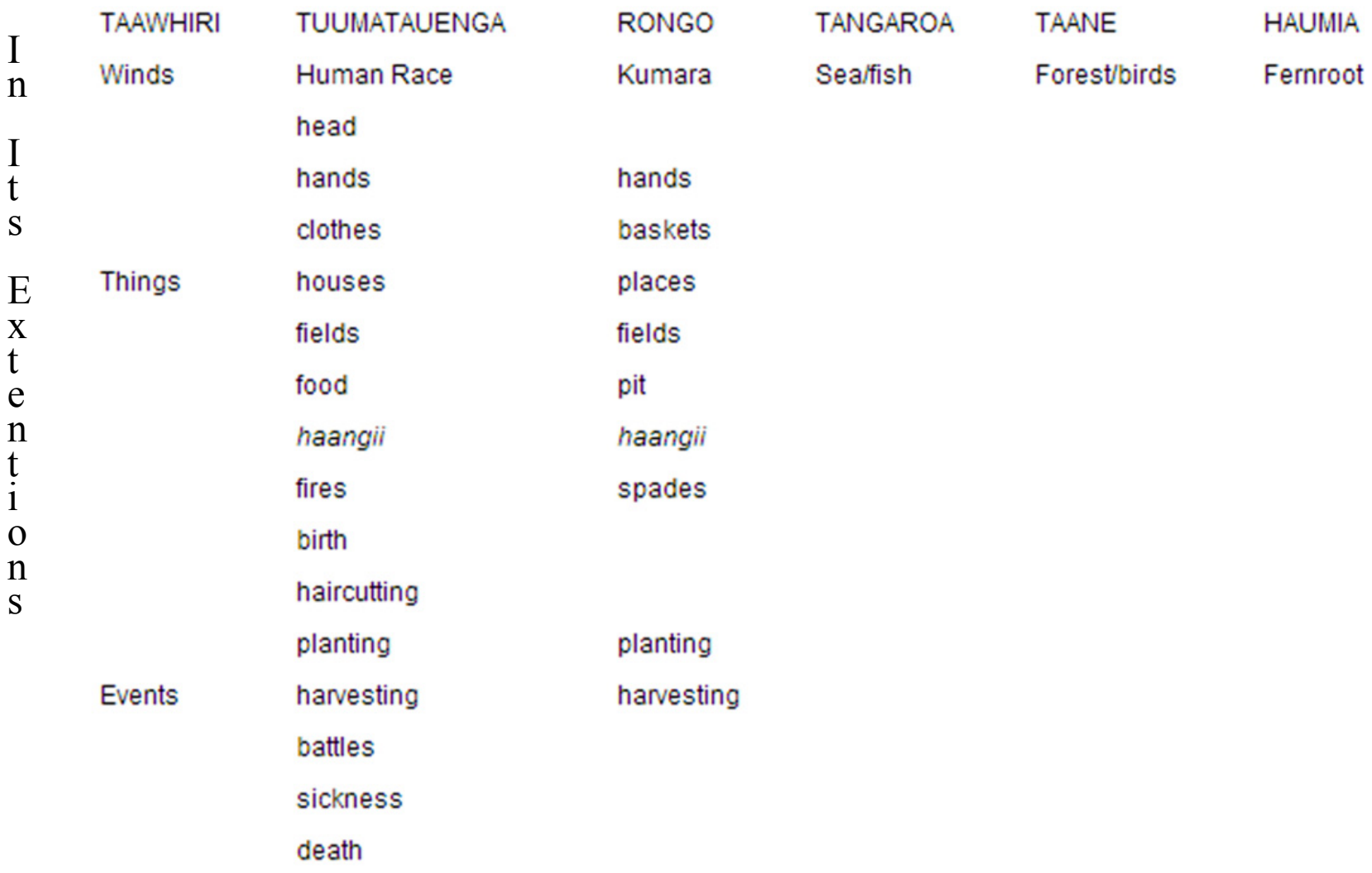

Figure 4.6 A Structural Presentation of Different Permutations of Tapu Thought. This is Shirres' table relating forms of intrinsic tapu to their extensions. The table is dominated by the two primary forms of intrinsic tapu identified by Shirres, the tapu of Tumatauenga (god of the human race and warfare) and Rongomatane (God of the kumara and all cultivated foods). 


\section{Section Two: Conceptual Experimentation Description and Analysis}

The first experiment within this section focuses on the architecture of the wharenui and the cultural narratives embedded within it. The second experiment utilises Shirres' wider and more conceptual understanding of tapu and noa to challenge the architecture of the State House. It is not the intention of either experiment to generalise Māori architecture to the wharenui or the Mãori understanding of space to tapu and noa, but rather to utilise them as strong examples of collective cultural identity and resistance to colonisation, and position them as a nationally significant architecture and spatial ideology of similar but very different significance to the State House and architectural mechanisms of representation.

\section{Experiment One}

The first experiment investigates the socio-spatial knowledge that is embedded within the architecture of the wharenui, and engages it with sectional, planar, and axonometric architectural mechanisms of representation. Through this engagement the experiment extends the wharenui from being a response to colonisation to a challenge to the authority of the colonial position mediated by western architectural mechanisms of representation. The interaction between the wharenui and the architectural mechanisms of representation will establish a new architectural position that is neither Māori, nor Pākehā, nor something bi-cultural, but something other; in other words, something post-colonial.

In the first step, images of wharenui, collected from throughout New Zealand's geography and history through archival and historical research, were collated into groups depicting specific parts of the wharenui: the interior elevation of the side wall (Fig.4.7), the front entrance (Fig.4.8), the side post supporting the front of the roof gable (Fig.4.9), the connection of the side wall to the ceiling and roof structure (Fig.4.10), and the interior hall space (Fig.4.11). The individual images from within each group had their size and transparency digitally altered in order for them to be overlaid and merged into a single image.

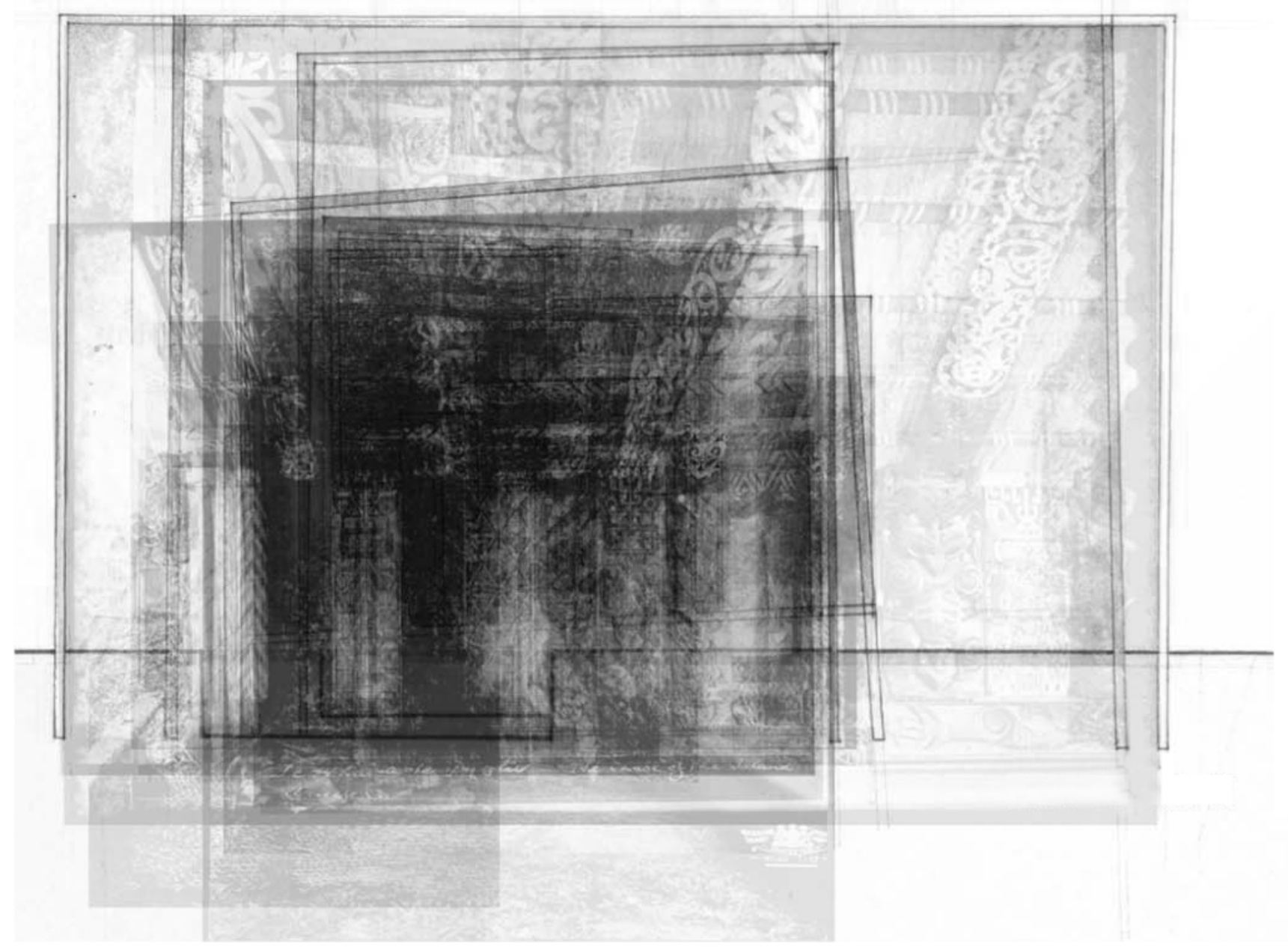

Figure 4.7 Wharenui Depiction Image 1: Interior Whakairo and Tukutuku. 


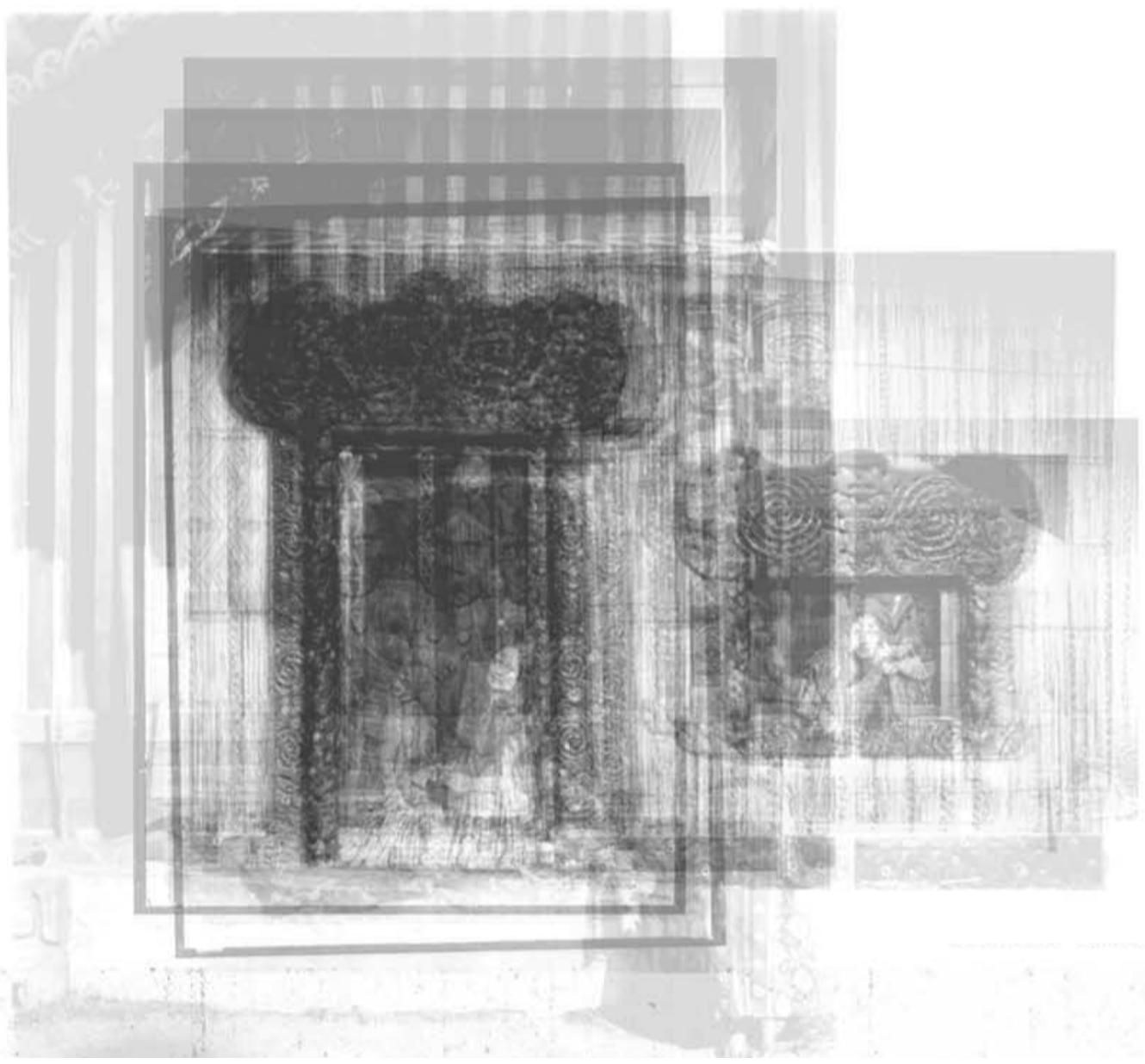

Figure 4.8 Wharenui Depiction Image 2: Front Entrance Kūwaha, Pare, Whakawae, Whatitoka, and Matapihi.

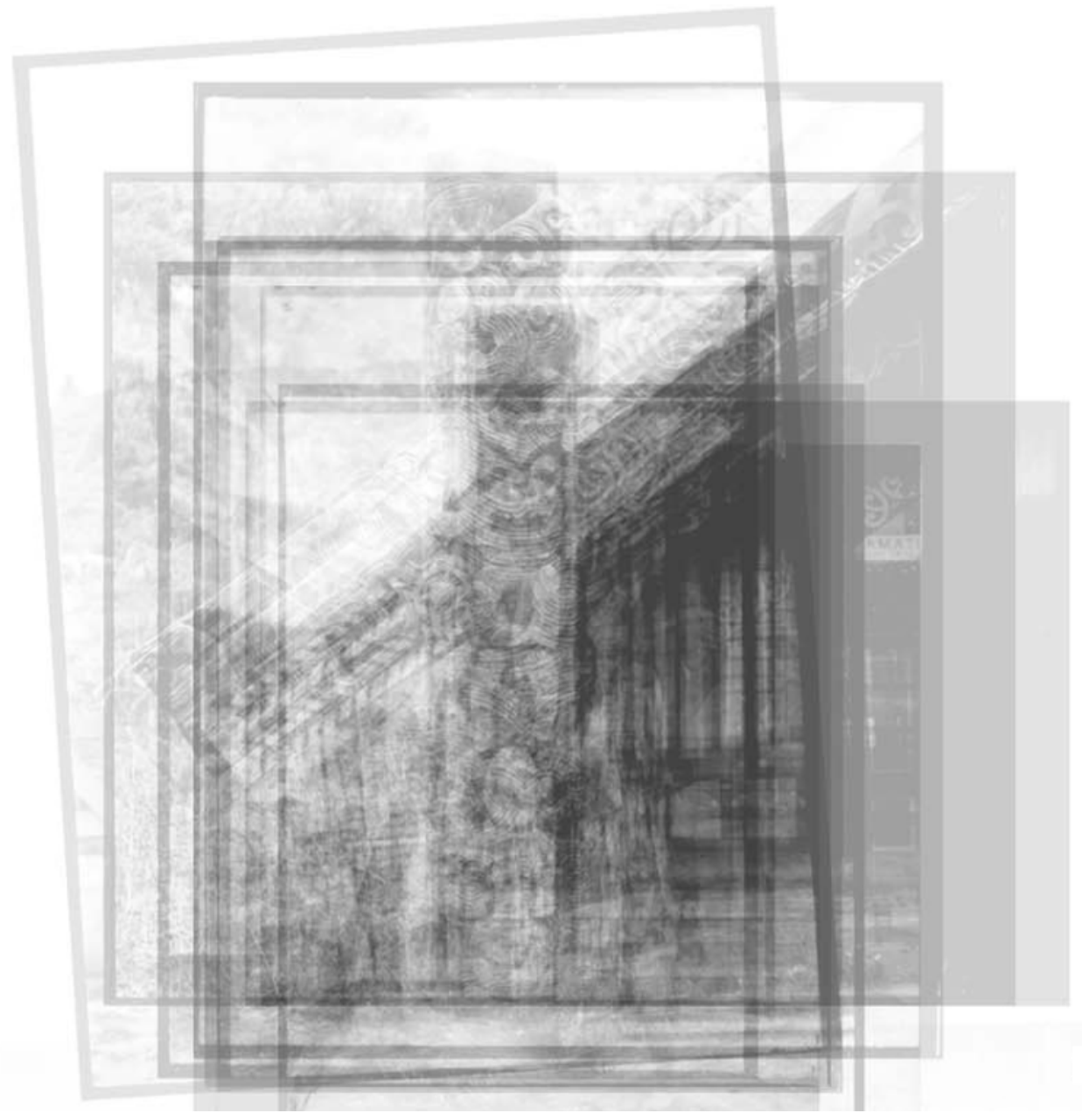

Figure 4.9 Wharenui Depiction Image 3: Front Amo and Raparapa. 


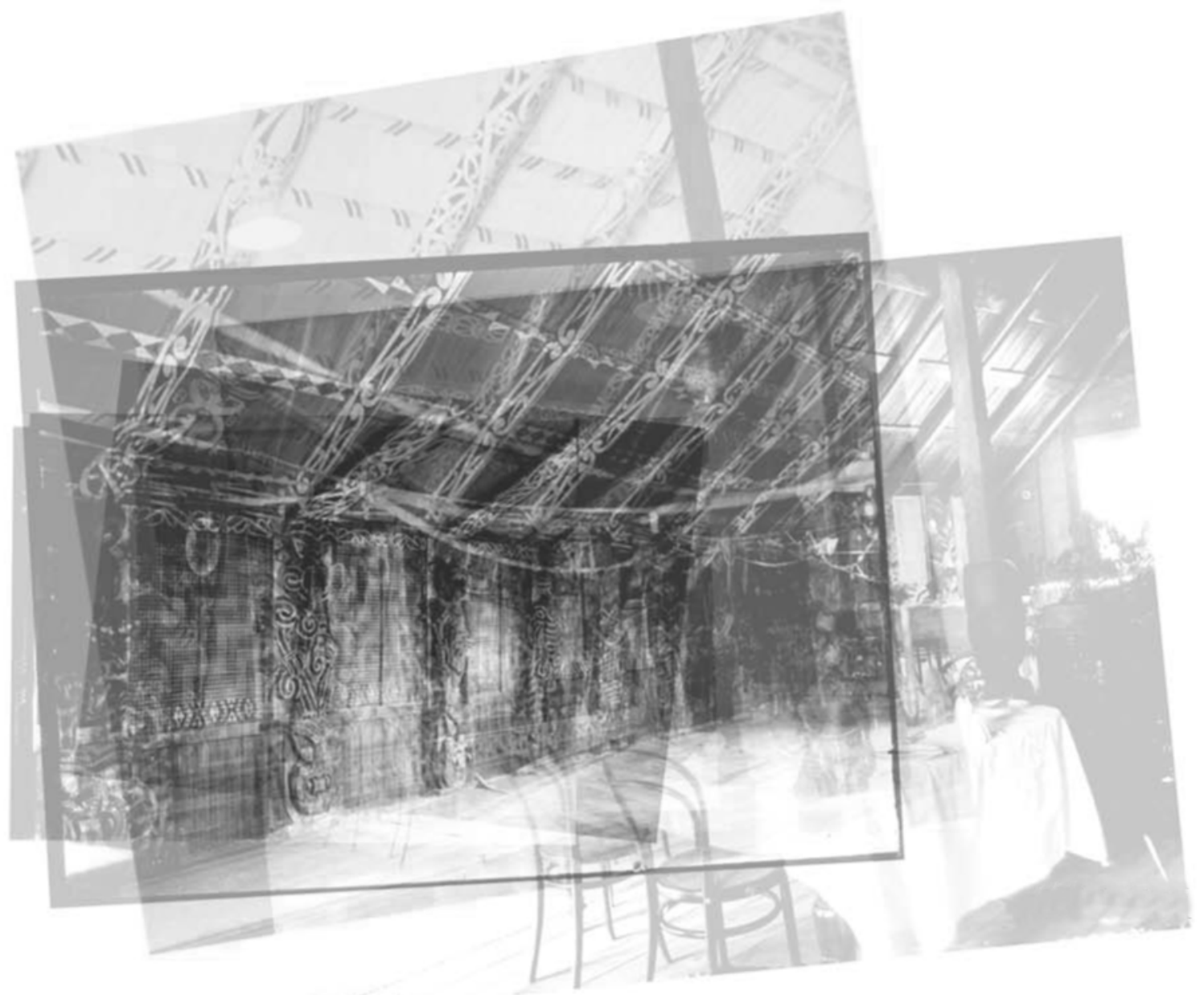

Figure 4.10 Wharenui Depiction Image 4: Interior Perspective, Whakairo, Tukutuku, and Kowhaiwhai.

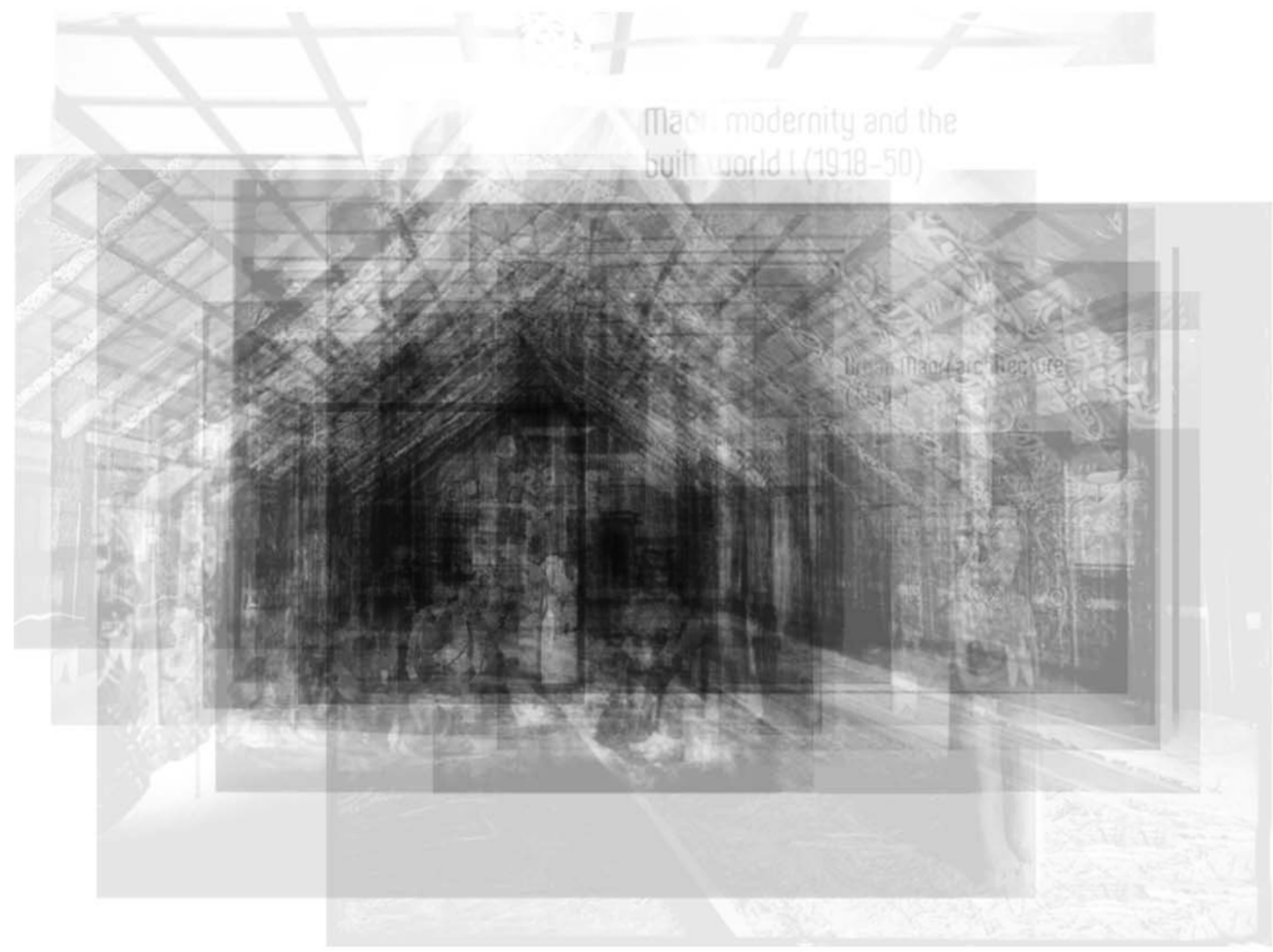

Figure 4.11 Wharenui Depiction Image 5: Interior Perspective of Wharenui Interior Space. 
The second step involved reading these images as depictions of architectural space, and representing them first as architectural section drawings (Fig.4.12-4.16), then as plan drawings (Fig.4.17-4.21), and last as axonometric drawings (Fig.4.22-4.26). This step forced an interaction between western architectural mechanisms of representation (section, plan and axonometric drawing) and the collective narrative of the images of wharenui created in step one (Fig.4.27-4.31). The interaction further established a new conceptual architectural position that engaged with, but is also estranged from, the two original positions, which are therefore made impure and are to a certain extent misread. The drawings cease to be read as depictions or representations of wharenui, and the mechanism of representation renders the building site-less, nor can they be easily read or interpreted as sections, plans, and axonometric representations of a definitive architecture.

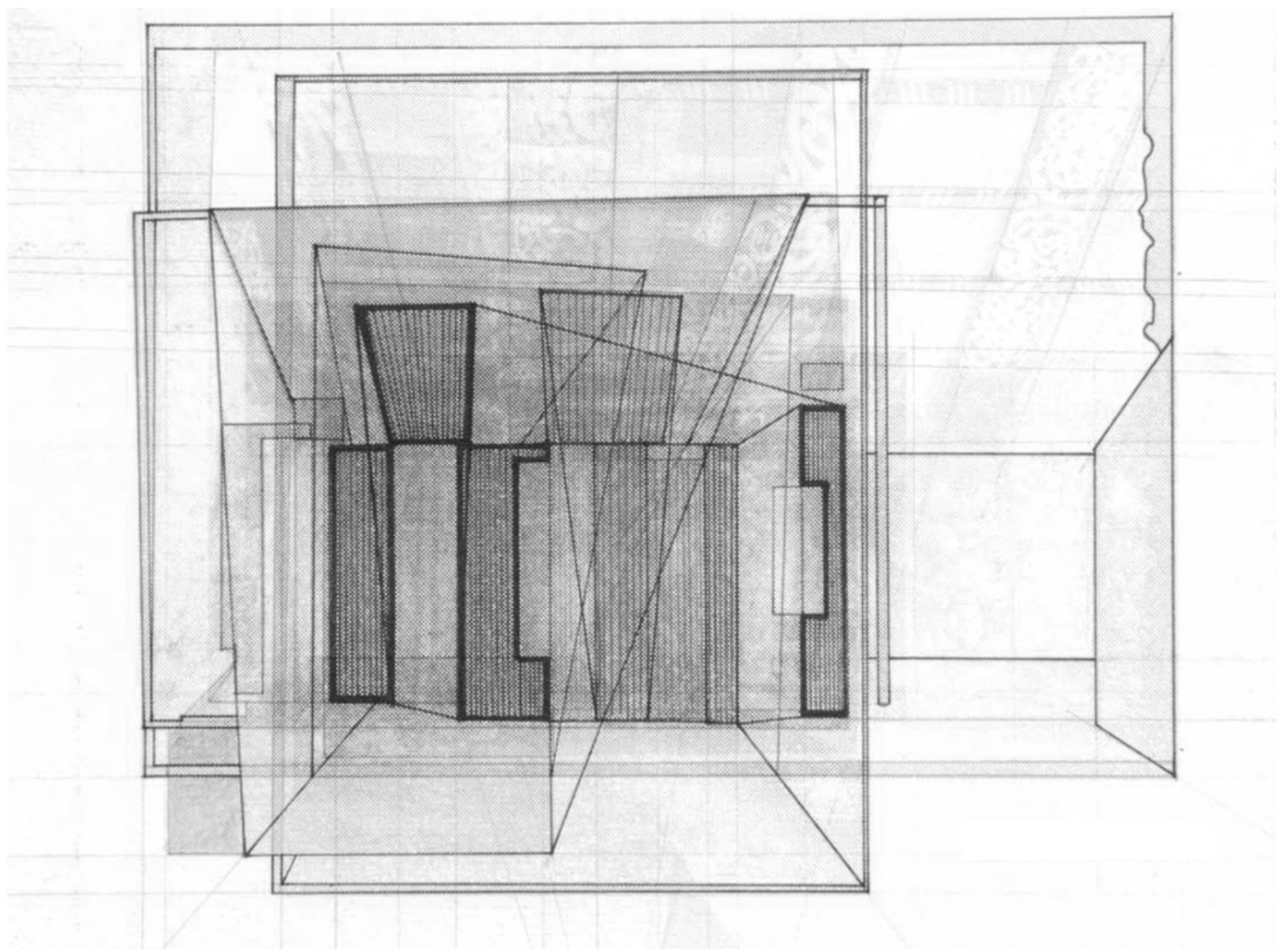

Figure 4.12 Sectional Representation of Depiction Image 1. Figure 4.7 was read as a sectional cut and then re-drawn to create this image. 
Joshua Blandford. Possibilities Towards a Post-Colonial Architecture in Residential New Zealand

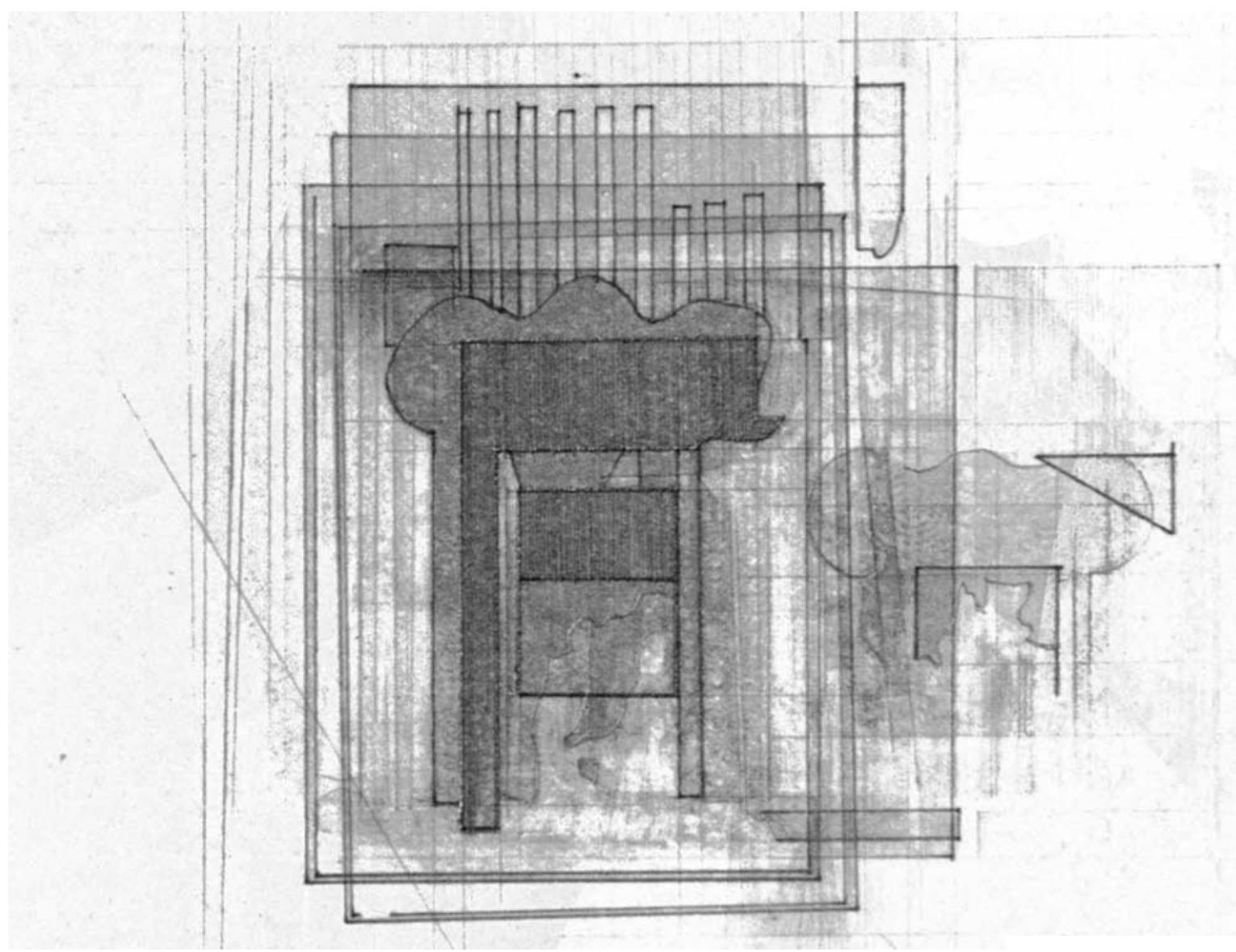

Figure 4.13 Sectional Representation of Depiction Image 2. Figure 4.8 was read as a sectional cut and then re-drawn to create this image.

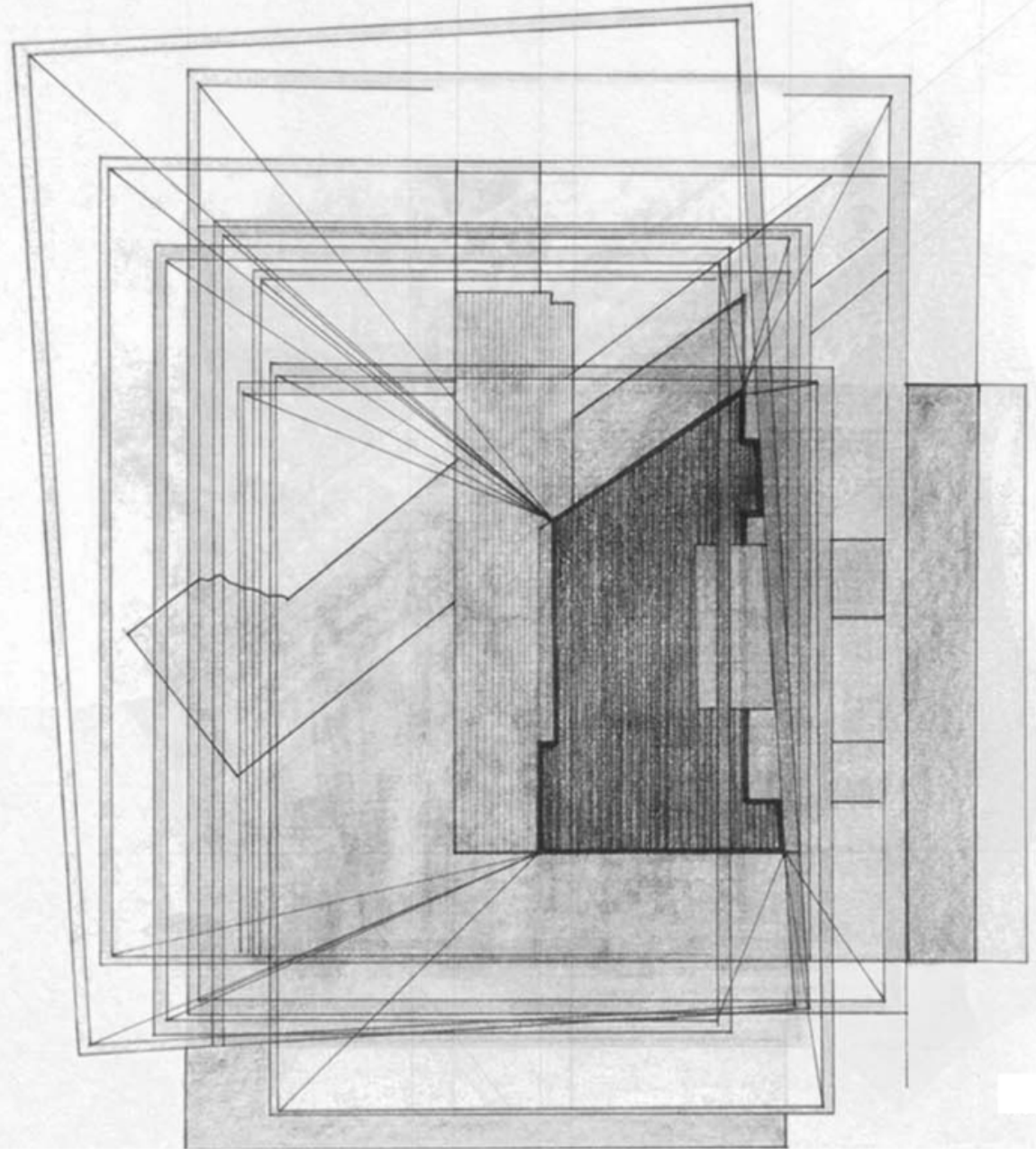

Figure 4.14 Sectional Representation of Depiction Image 3. Figure 4.9 was read as a sectional cut and then re-drawn to create this image. 
Joshua Blandford. Possibilities Towards a Post-Colonial Architecture in Residential New Zealand

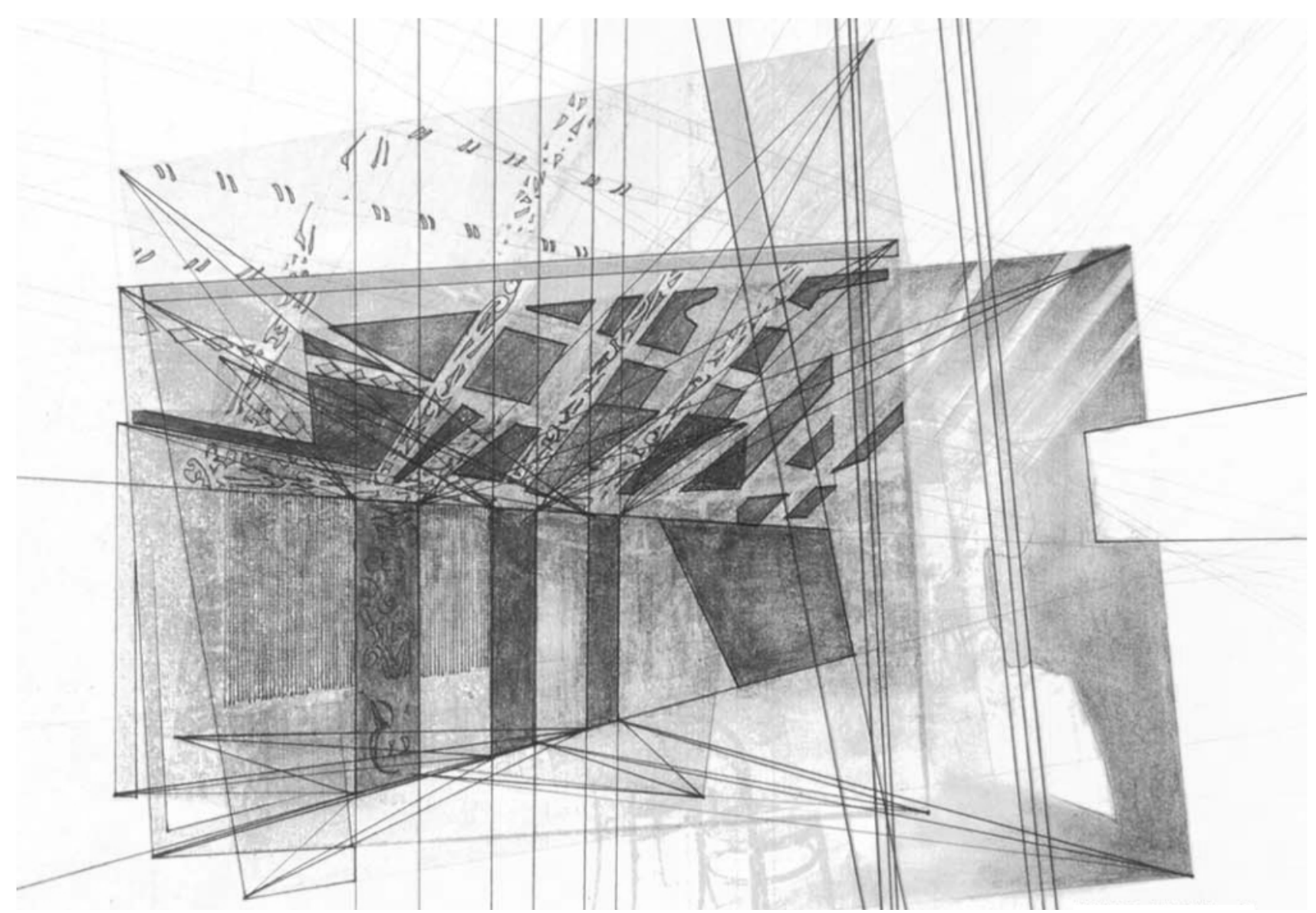

Figure 4.15 Sectional Representation of Depiction Image 4. Figure 4.10 was read as a sectional cut and then re-drawn to create this image.

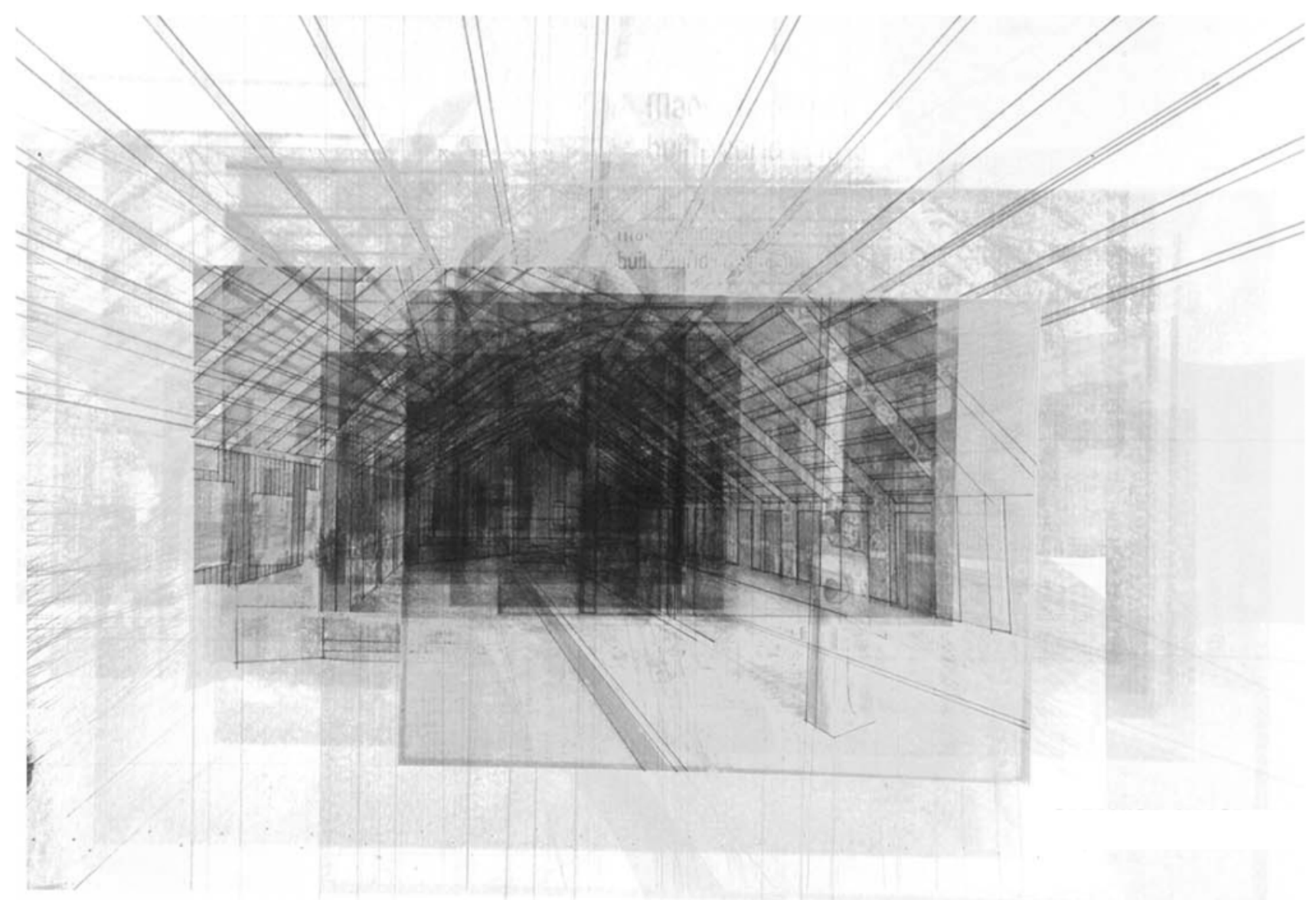

Figure 4.16 Sectional Representation of Depiction Image 5. Figure 4.11 was read as a sectional cut and then re-drawn to create this image. 


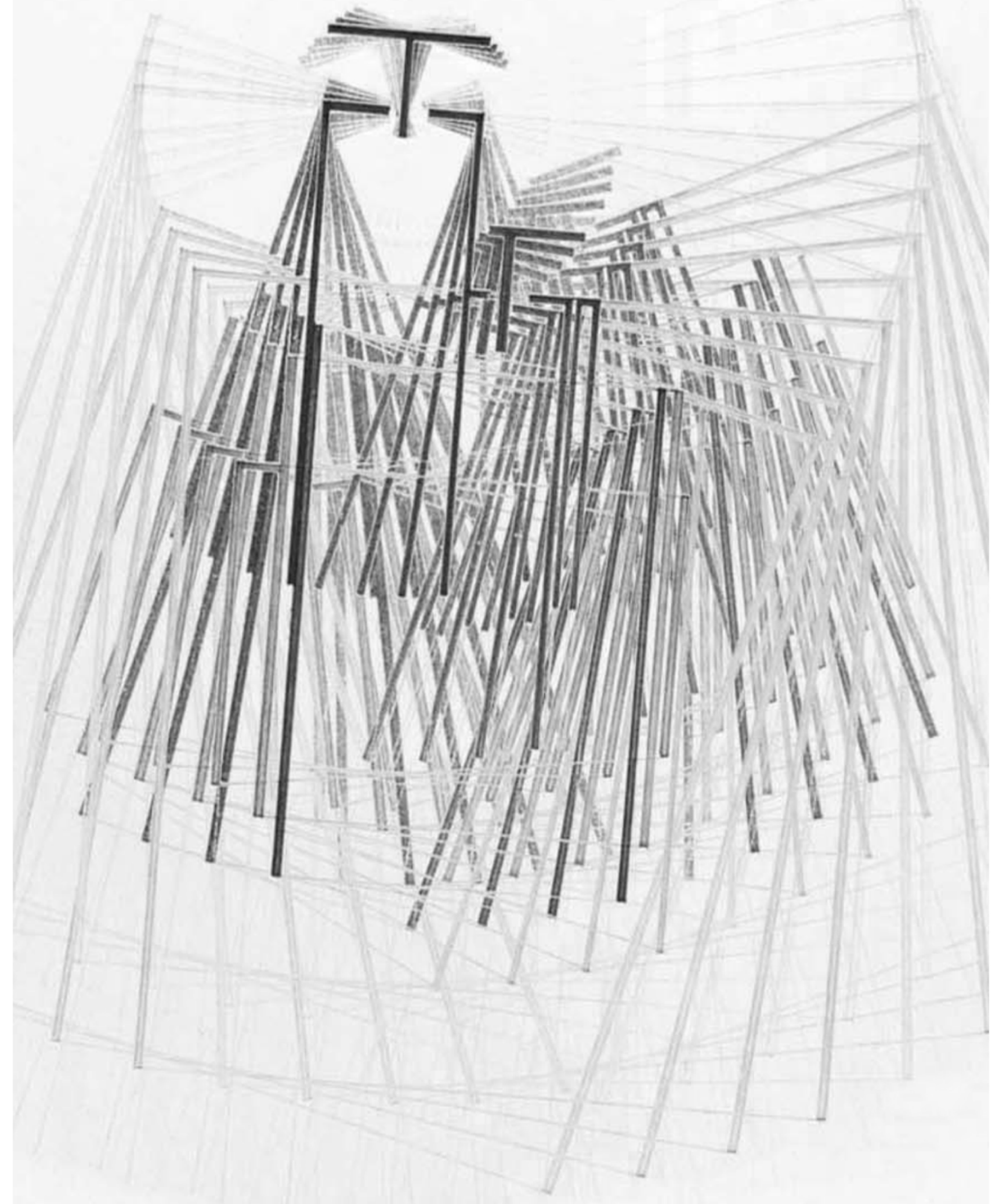

Figure 4.17 Planar Representation of Depiction Image 1. Figures 4.7 and 4.12 were used to create a planar representation of the same space. Darkness within the original depiction and sectional representation were read as deeper and more solid elements, and lighter areas as shallower and more transparent/softer elements. The image also conveys the tension between different genealogies and ancestry within the original depiction. 


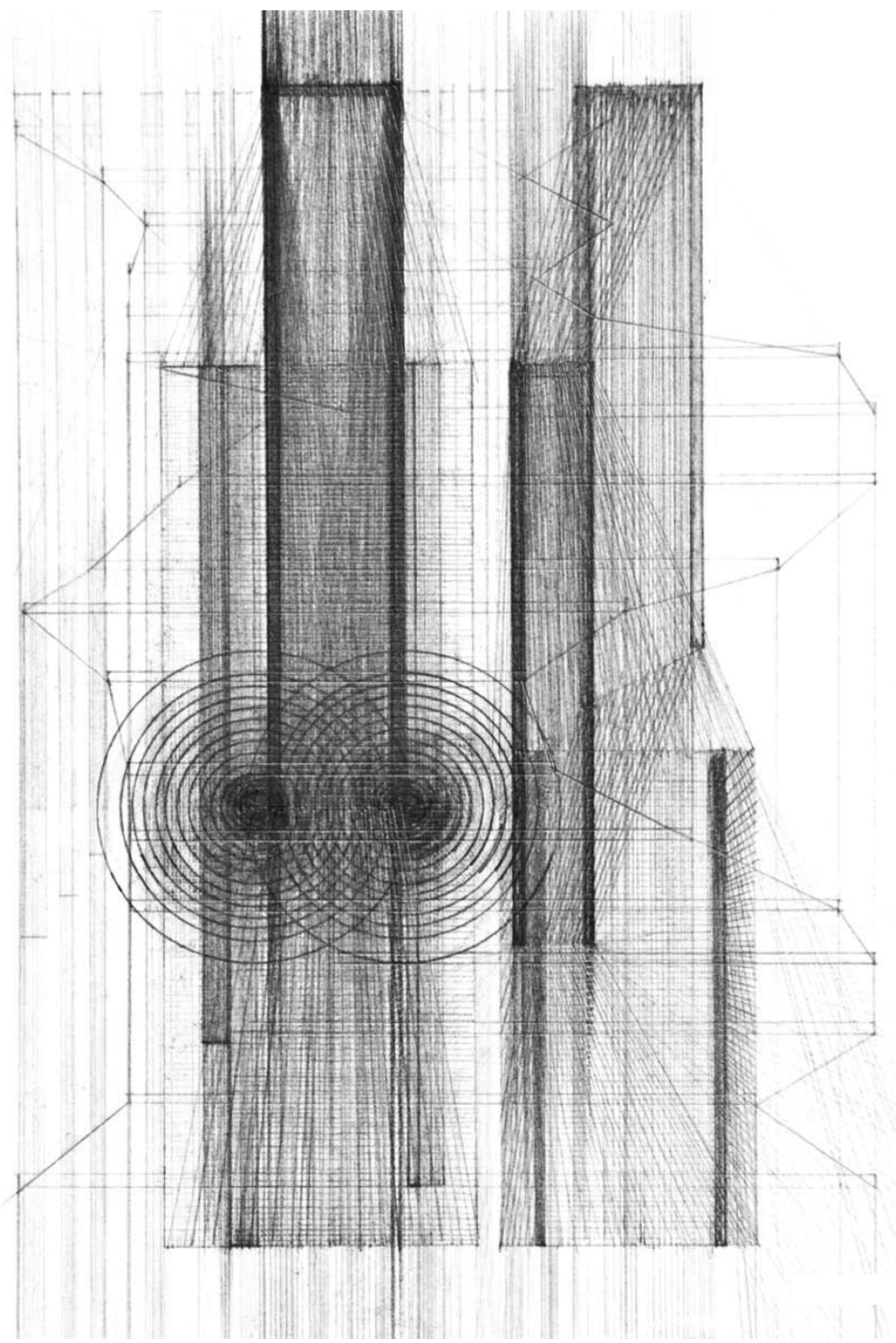

Figure 4.18 Planar Representation of Depiction Image 2. Figures 4.8 and 4.13 were used to create a planar representation of the same space. Darkness within the original depiction and sectional representation were read as deeper and more solid elements, and lighter areas as shallower and more transparent/softer elements. The image also conveys the transition between states represented within this space of the wharenui. 


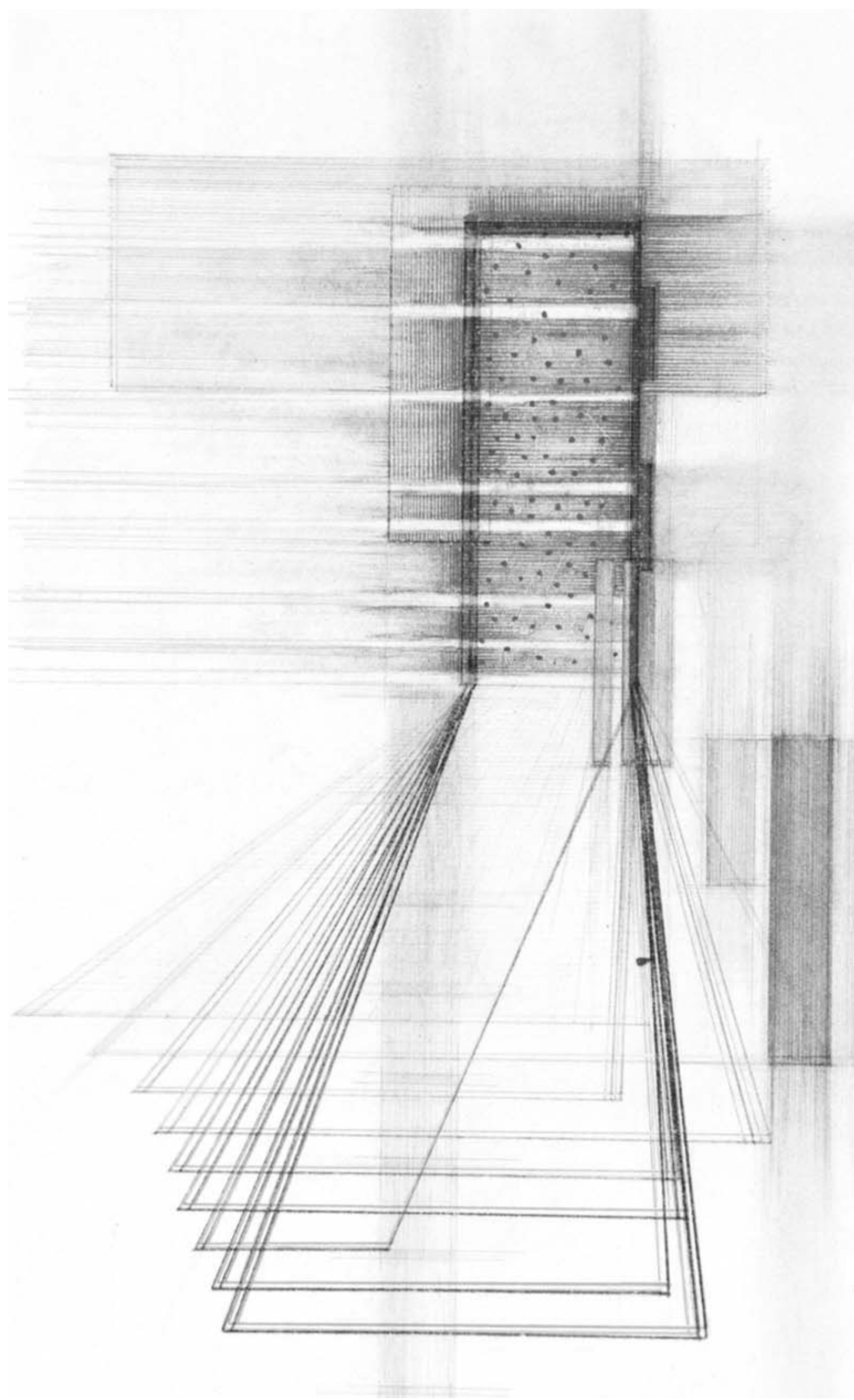

Figure 4.19 Planar Representation of Depiction Image 3. Figures 4.9 and 4.14 were used to create a planar representation of the same space. Darkness within the original depiction and sectional representation were read as deeper and more solid elements, and lighter areas as shallower and more transparent/softer elements. The image also conveys the tension between different genealogies and ancestry within the original depiction. 


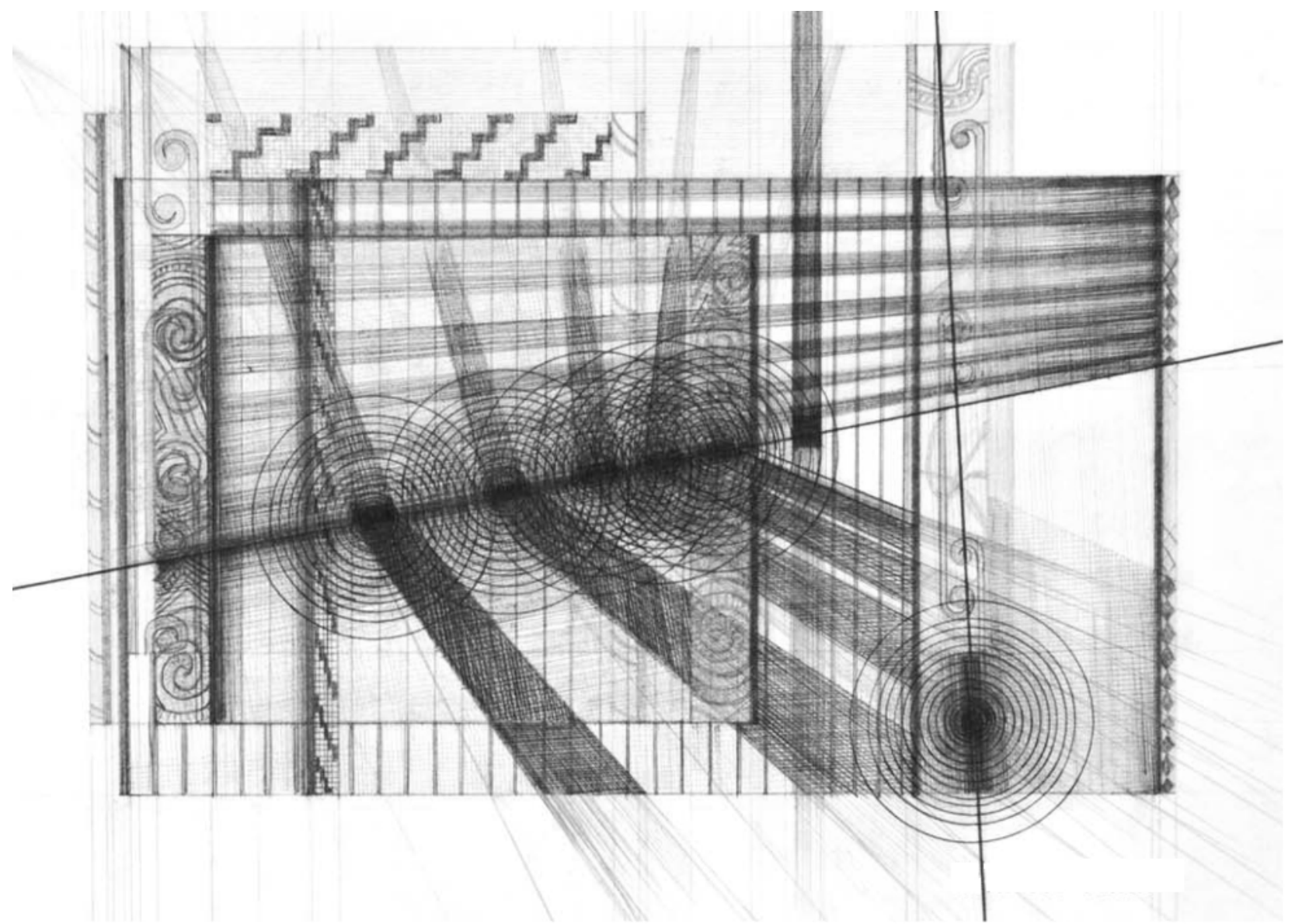

Figure 4.20 Planar Representation of Depiction Image 4. Figures 4.10 and 4.15 were used to create a planar representation of the same space. Darkness within the original depiction and sectional representation were read as deeper and more solid elements, and lighter areas as shallower and more transparent/softer elements. The image also conveys the tension between different genealogies and ancestry within the original depiction.

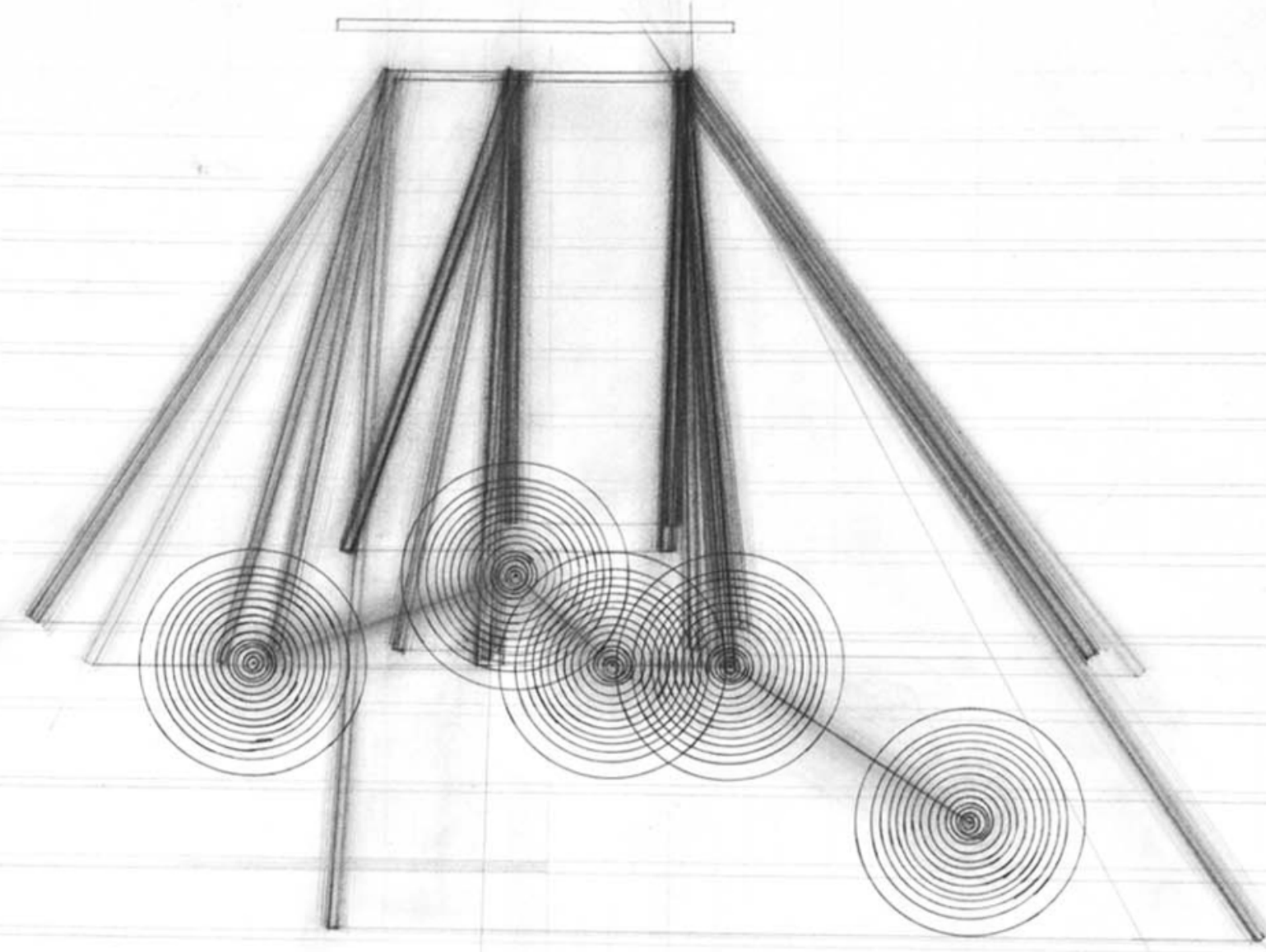

Figure 4.21 Planar Representation of Depiction Image 5. Figures 4.11 and 4.16 were used to create a planar representation of the same space. Darkness within the original depiction and sectional representation were read as deeper and more solid elements, and lighter areas as shallower and more transparent/softer elements. The image also conveys the tension between different genealogies and ancestry within the original depiction. 


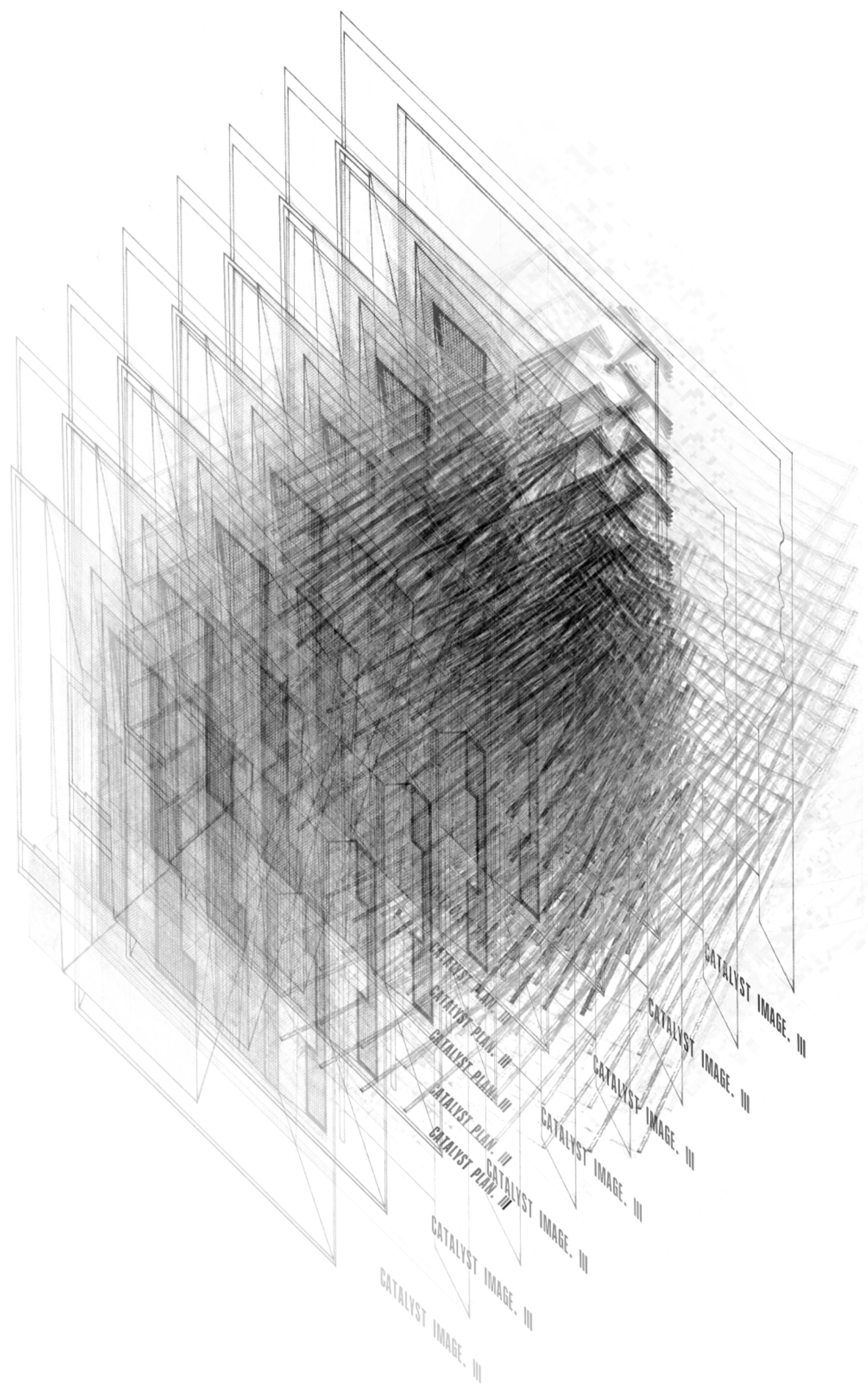

Figure 4.22 Axonometric Representation of Depiction Image 1. This axonometric representation was created through digitally duplicating and overlaying Figures 4.12 and 4.17 in order to realise the outcome as a three dimensional spatial representation. 


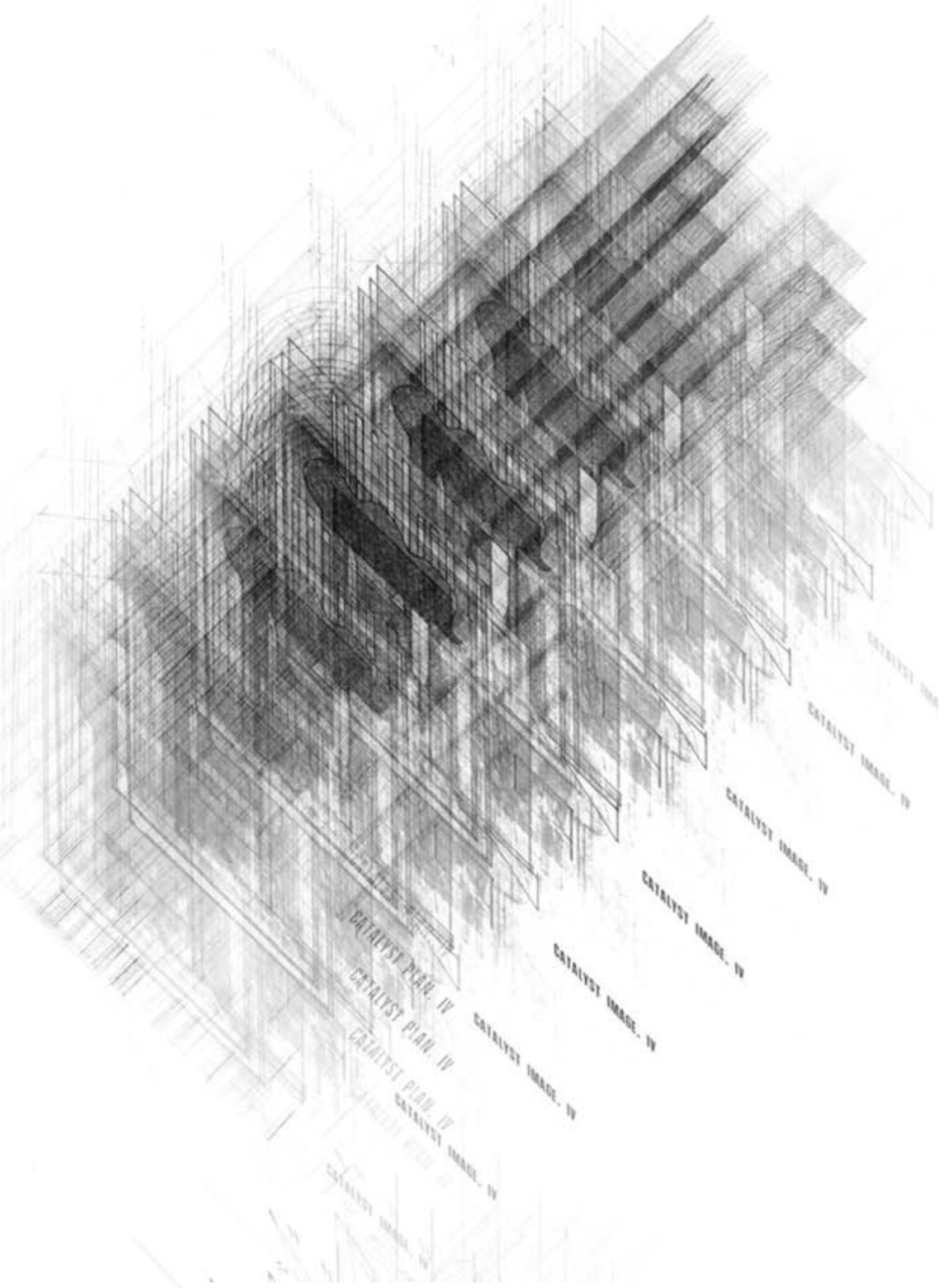

Figure 4.23 Axonometric Representation of Depiction Image 2. This axonometric representation was created through digitally duplicating and overlaying Figures 4.13 and 4.18 in order to realise the outcome as a three dimensional spatial representation. 


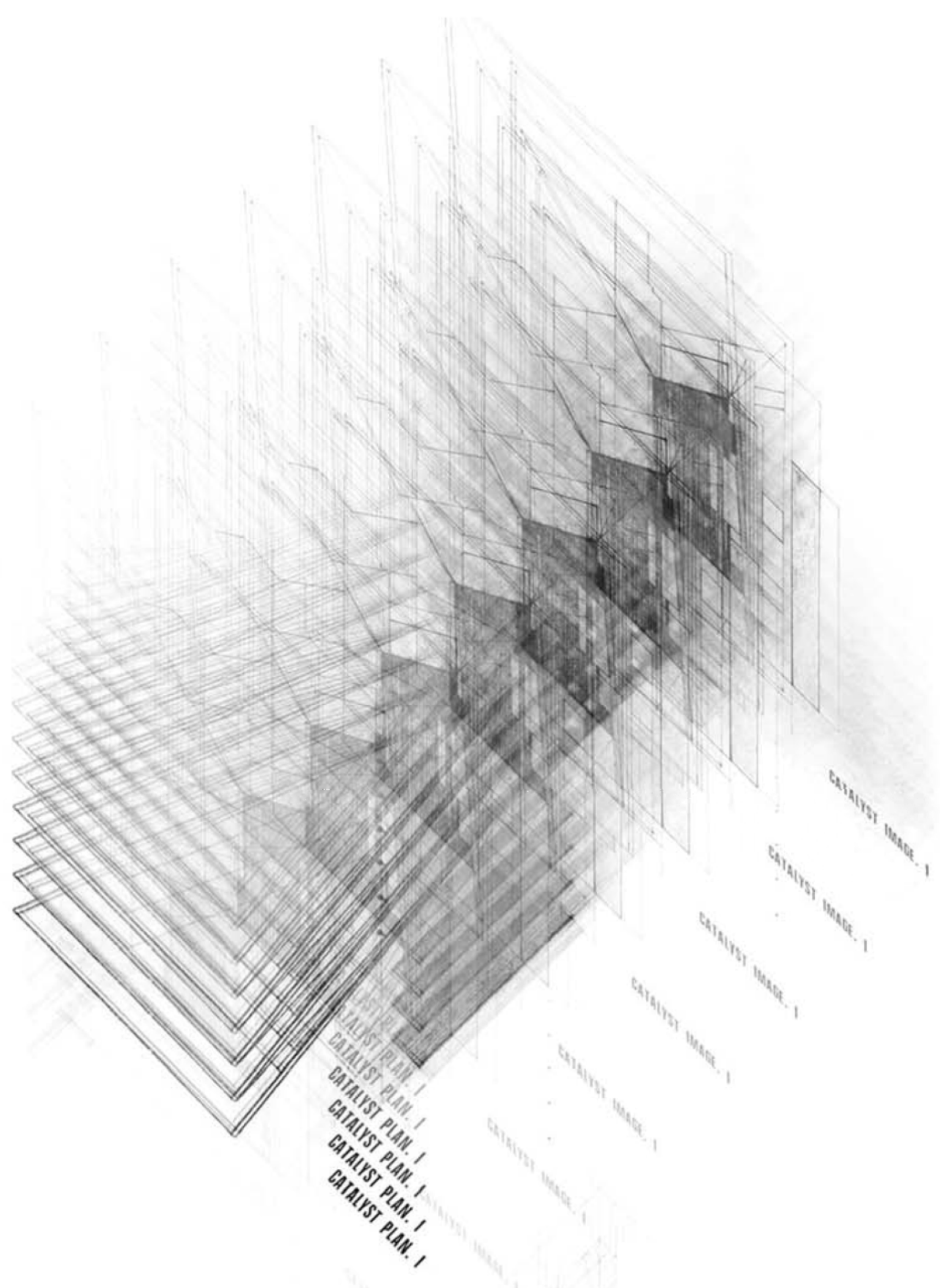

Figure 4.24 Axonometric Representation of Depiction Image 3. This axonometric representation was created through digitally duplicating and overlaying Figures 4.14 and 4.19 in order to realise the outcome as a three dimensional spatial representation. 


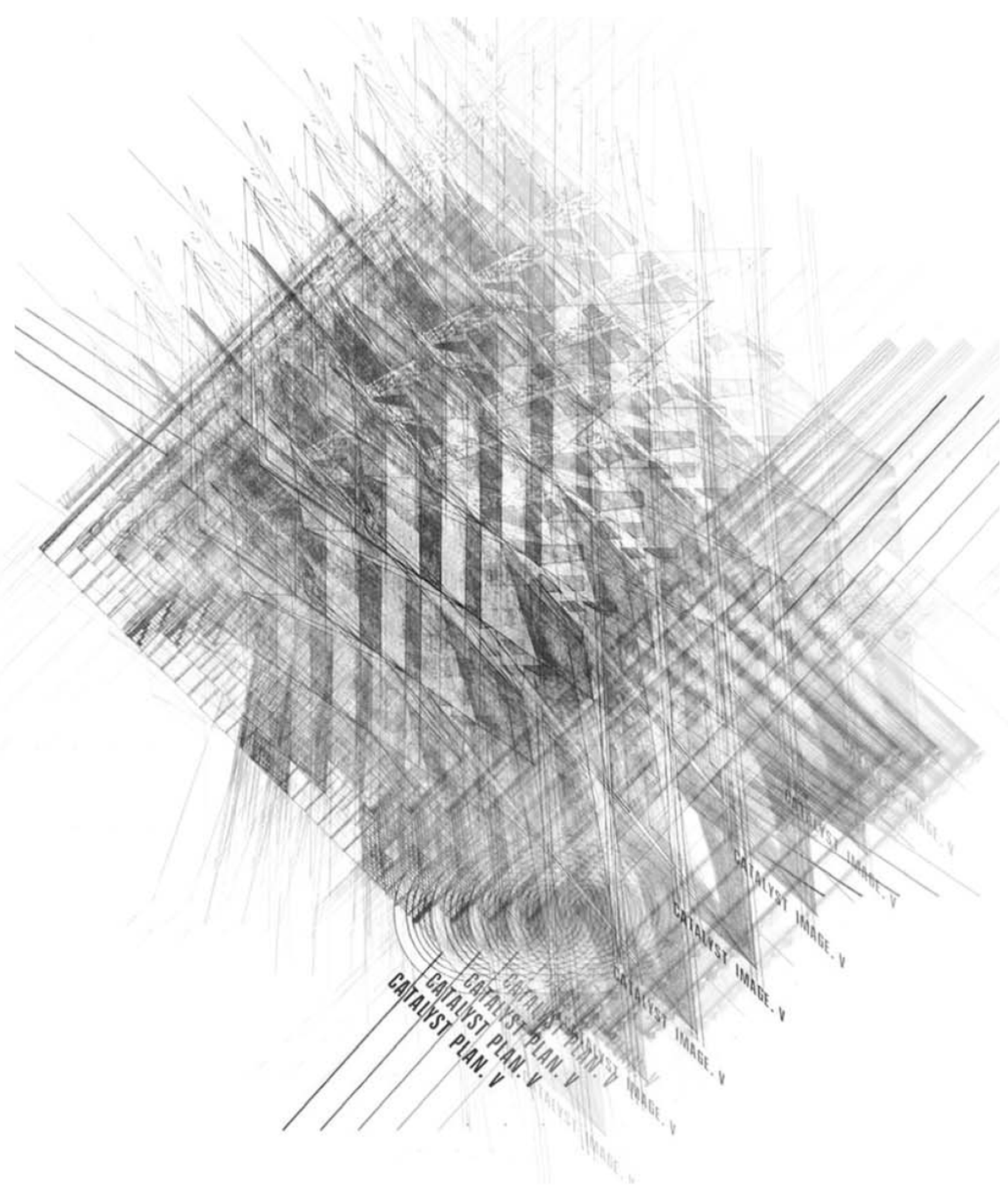

Figure 4.25 Axonometric Representation of Depiction Image 4. This axonometric representation was created through digitally duplicating and overlaying Figures 4.15 and 4.20 in order to realise the outcome as a three dimensional spatial representation. 


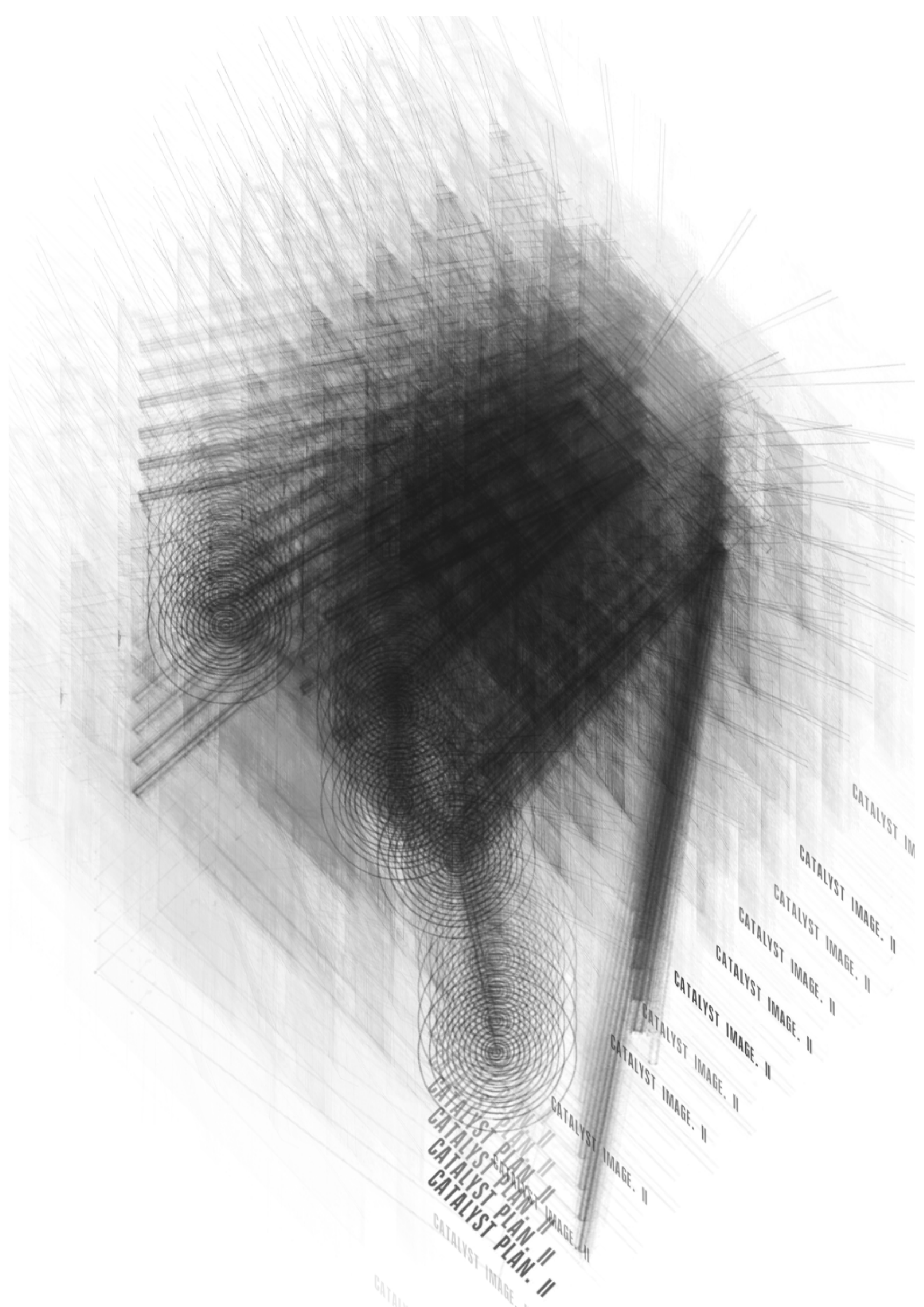

Figure 4.26 Axonometric Representation of Depiction Image 5. This axonometric representation was created through digitally duplicating and overlaying Figures 4.16 and 4.21 in order to realise the outcome as a three dimensional spatial representation. 

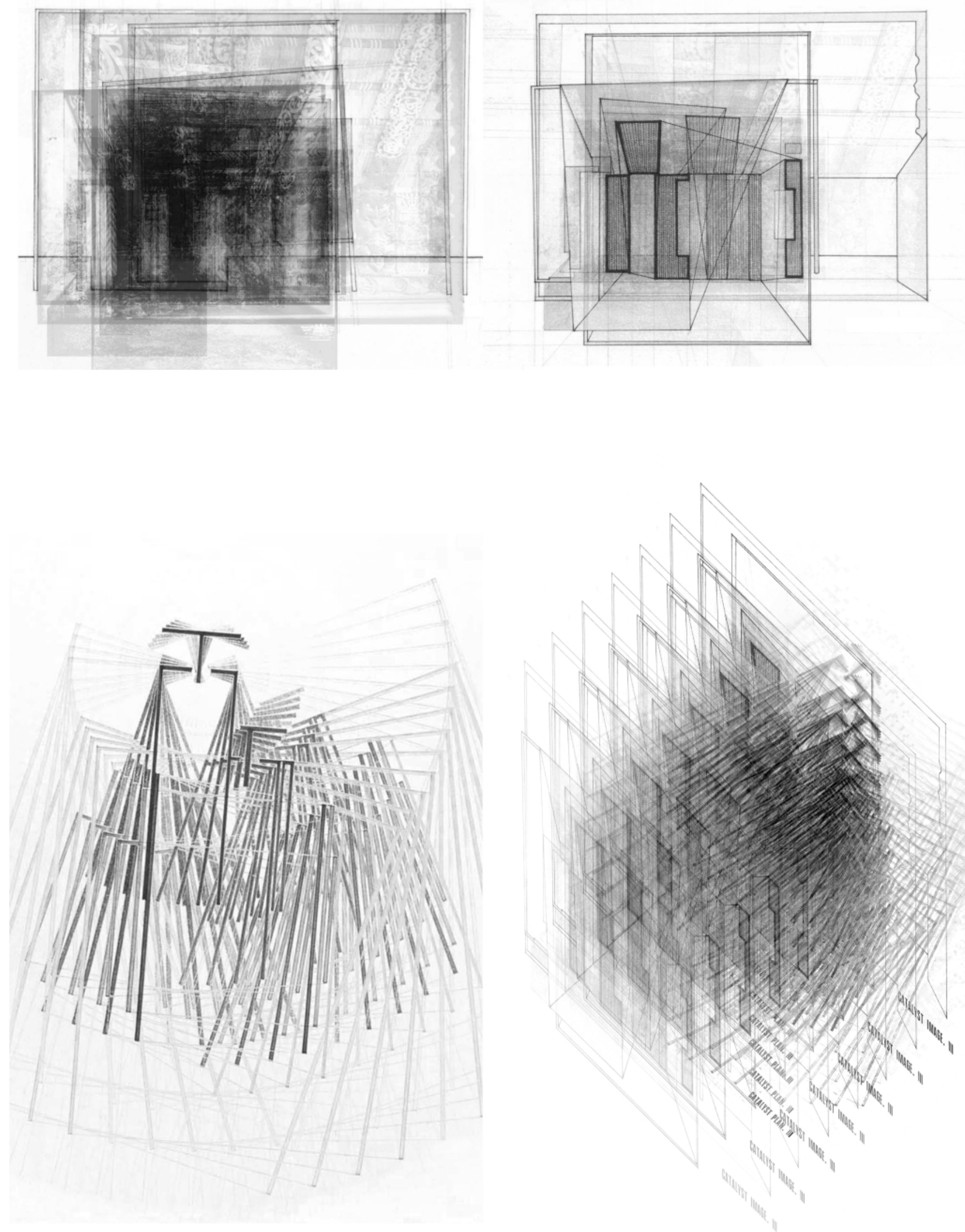

Figure 4.27 Image Group of Depiction Image 1. This shows the relationship between all of the drawings generated from Figure 4.7. 

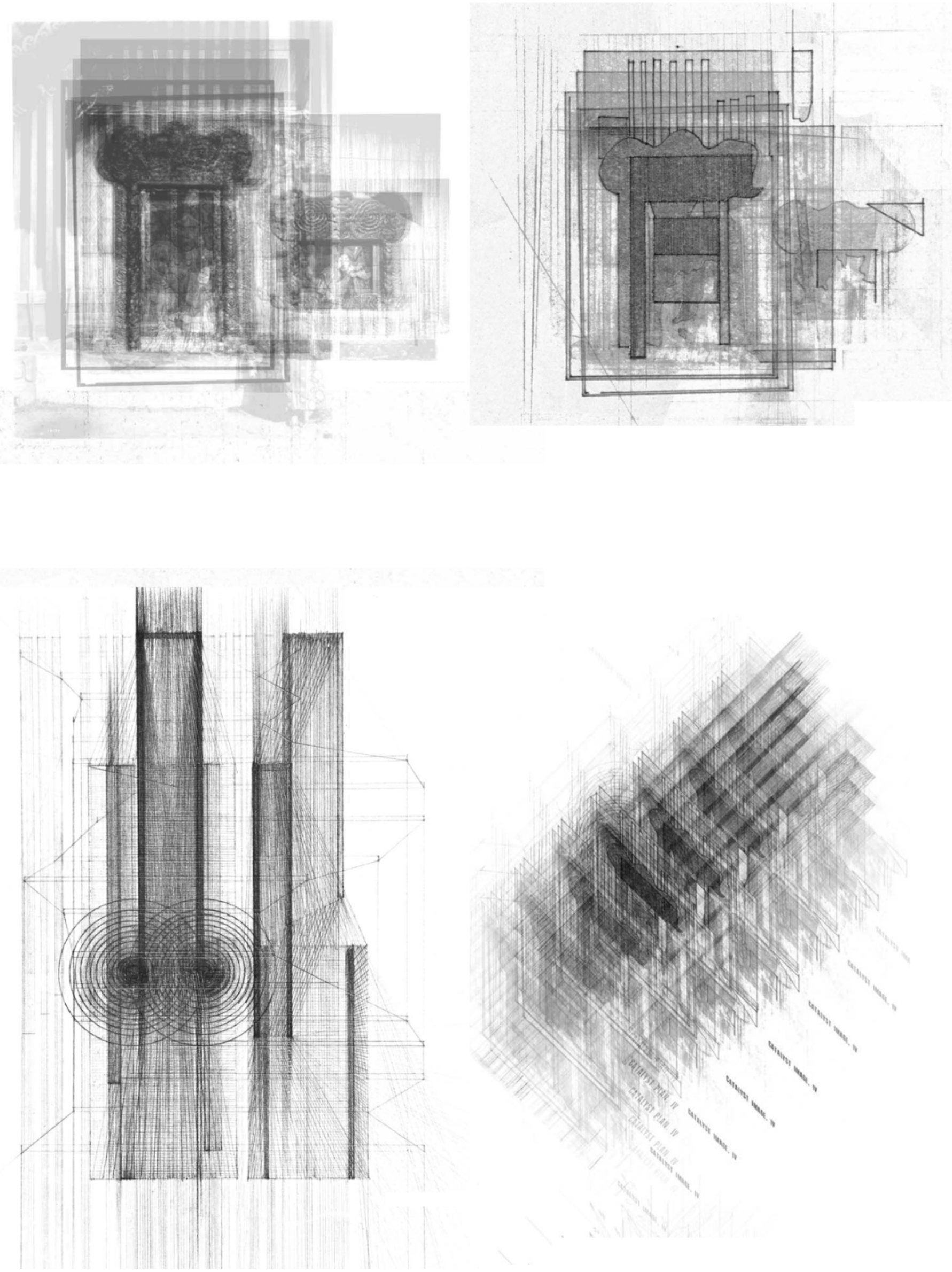

Figure 4.28 Image Group of Depiction Image 2. This shows the relationship between all of the drawings generated from Figure 4.8. 

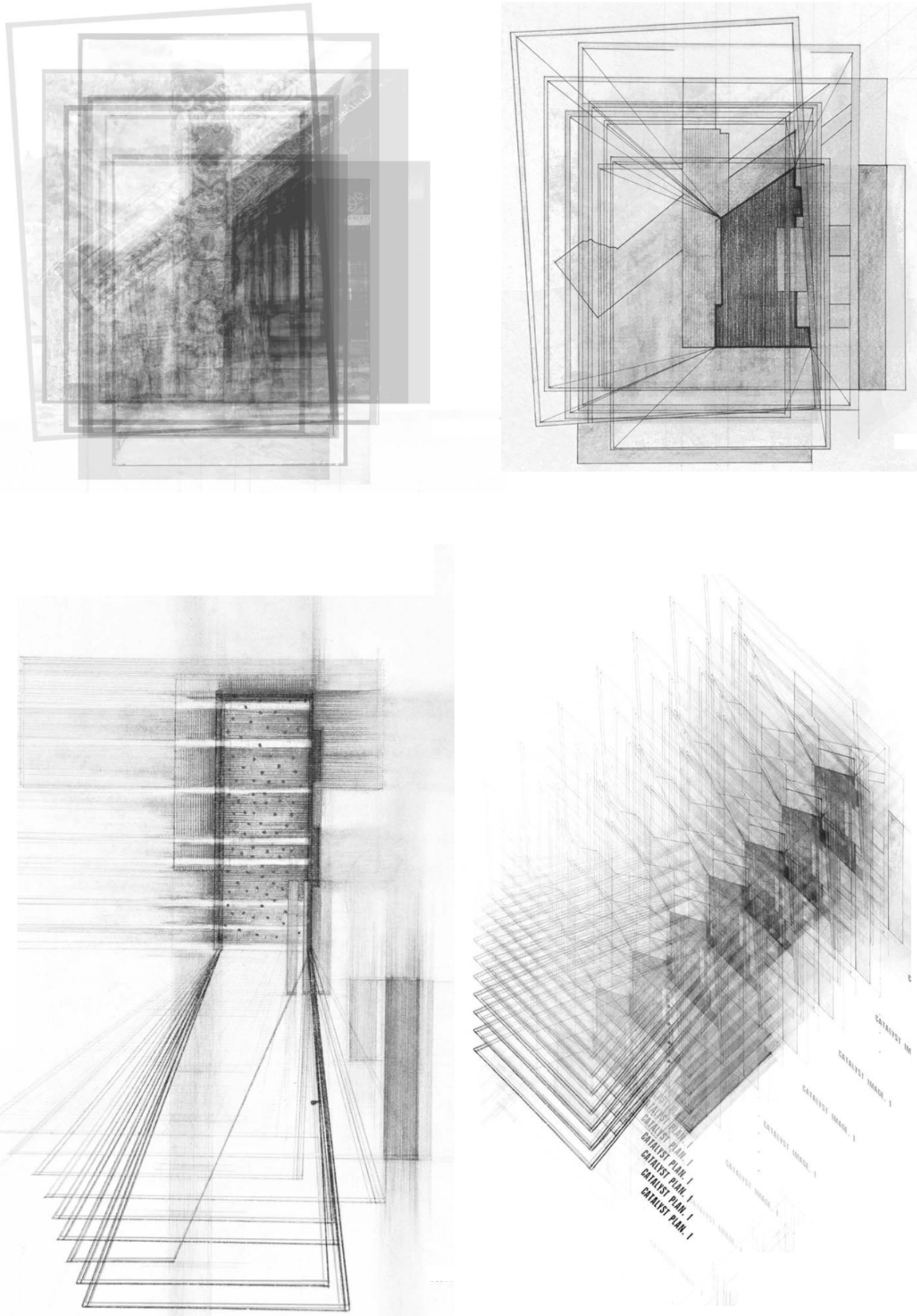

Figure 4.29 Image Group of Depiction Image 3. This shows the relationship between all of the drawings generated from Figure 4.9 

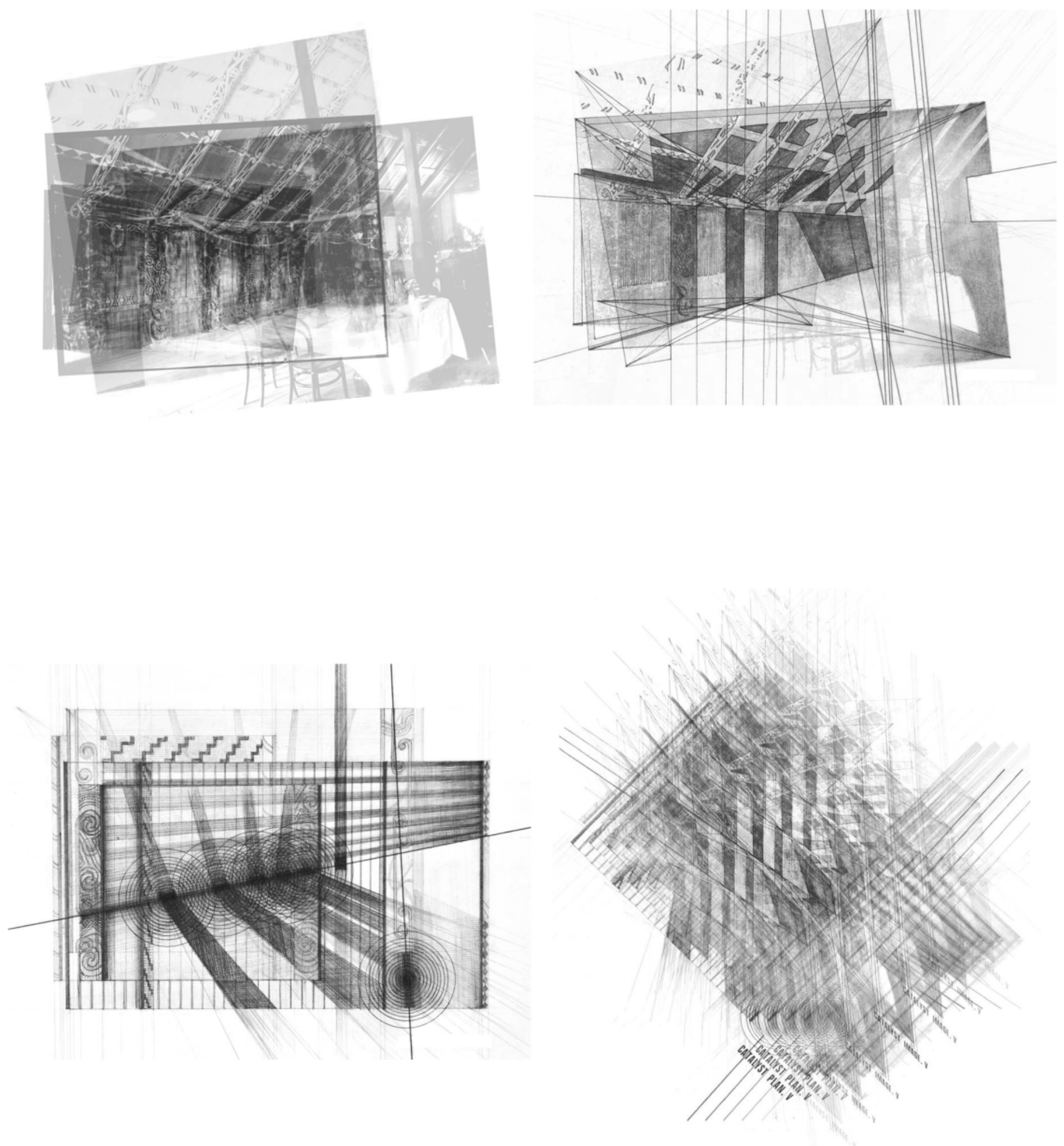

Figure 4.30 Image Group of Depiction Image 4. This shows the relationship between all of the drawings generated from Figure 4.10. 

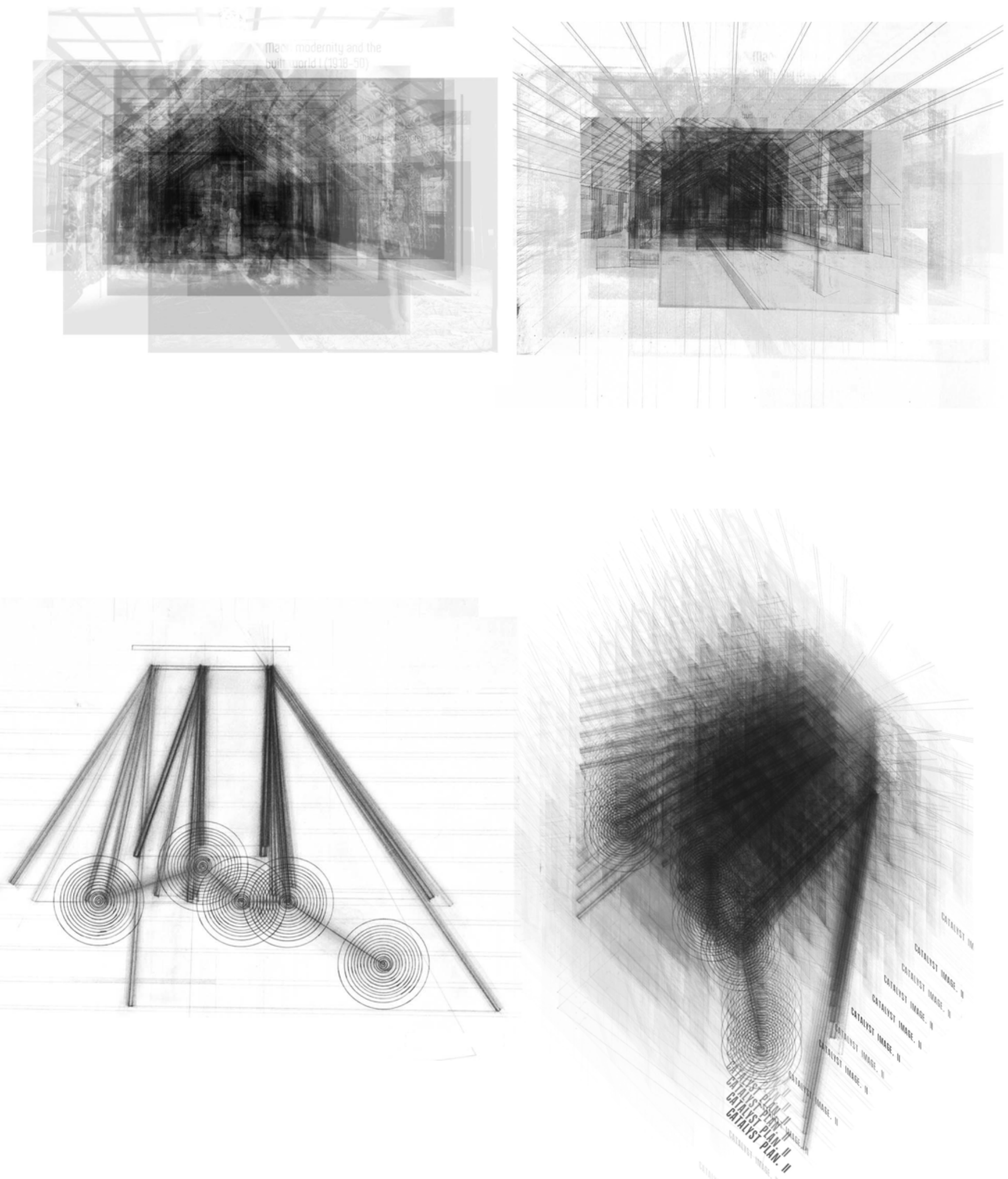

Figure 4.31 Image Group of Depiction Image 5. This shows the relationship between all of the drawings generated from Figure 4.11. 
Image group 2, generated from the depiction of the front entrance of the wharenui, was then developed into a digital model (Fig.4.32-4.34). ${ }^{141}$ This model was not considered as having a fully defined function or programme, and the focus was not to create a fully functional residential house at this stage. Rather, the intention was to present the drawings and model as a conceptual architectural outcome that presented a possibility for a new spatial practice of dwelling. The model therefore retained a sense of ambiguity and uncertainty of use, but became more recognisable as a conceptual architectural object. The final model is to be read in conjunction with the interpretation of the representational images from which it was created, and serves to clarify or cement the possibility of the experiment as an architecturally realisable outcome, as opposed to a merely representational spatial image.

Due to the method of this experiment relying on established traditional architectural typologies, spatial narratives, and spatial practices, an assessment determining whether or not the architectural outcomes generated are practically and socially successful for contemporary New Zealand society is difficult to make. As the title and experiment description suggest, this experiment aimed to establish a method for engaging alternative cultural narratives with the colonial position favoured by architectural mechanisms of representation in order to create possibilities for a new architectural position.

Although architectural mechanisms of representation were still used to produce the architectural outcomes, the engagement of them with unfamiliar cultural narratives pushed their accepted boundaries and highlighted their representational limitations of space. Similarly, the process within the experiment forced a misreading of the wharenui, allowing a new architecture to emerge that engaged with the wharenui but was not bound by it. The outcomes cease to be realised as wharenui, as sited buildings, and as distinctively Mãori; nor are they easily recognisable in terms of the expectations of architectural representations or pieces of conventional domestic architecture.

141 It is for reasons of scope that this group of drawings only was developed into a digital model and architectural design in Chapter 5. 


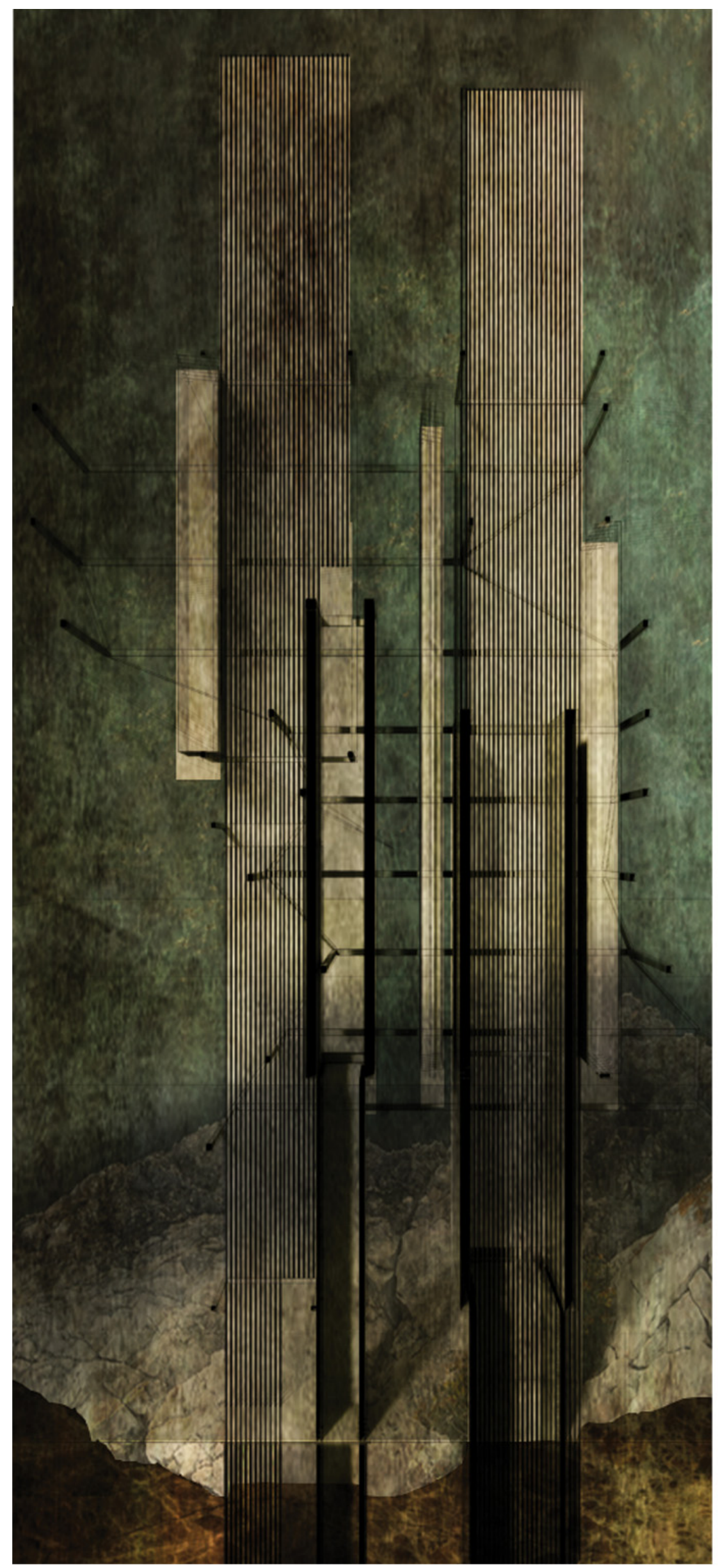

Figure 4.32 Plan of Conceptual Outcome Generated from Image Group of Depiction 2. 


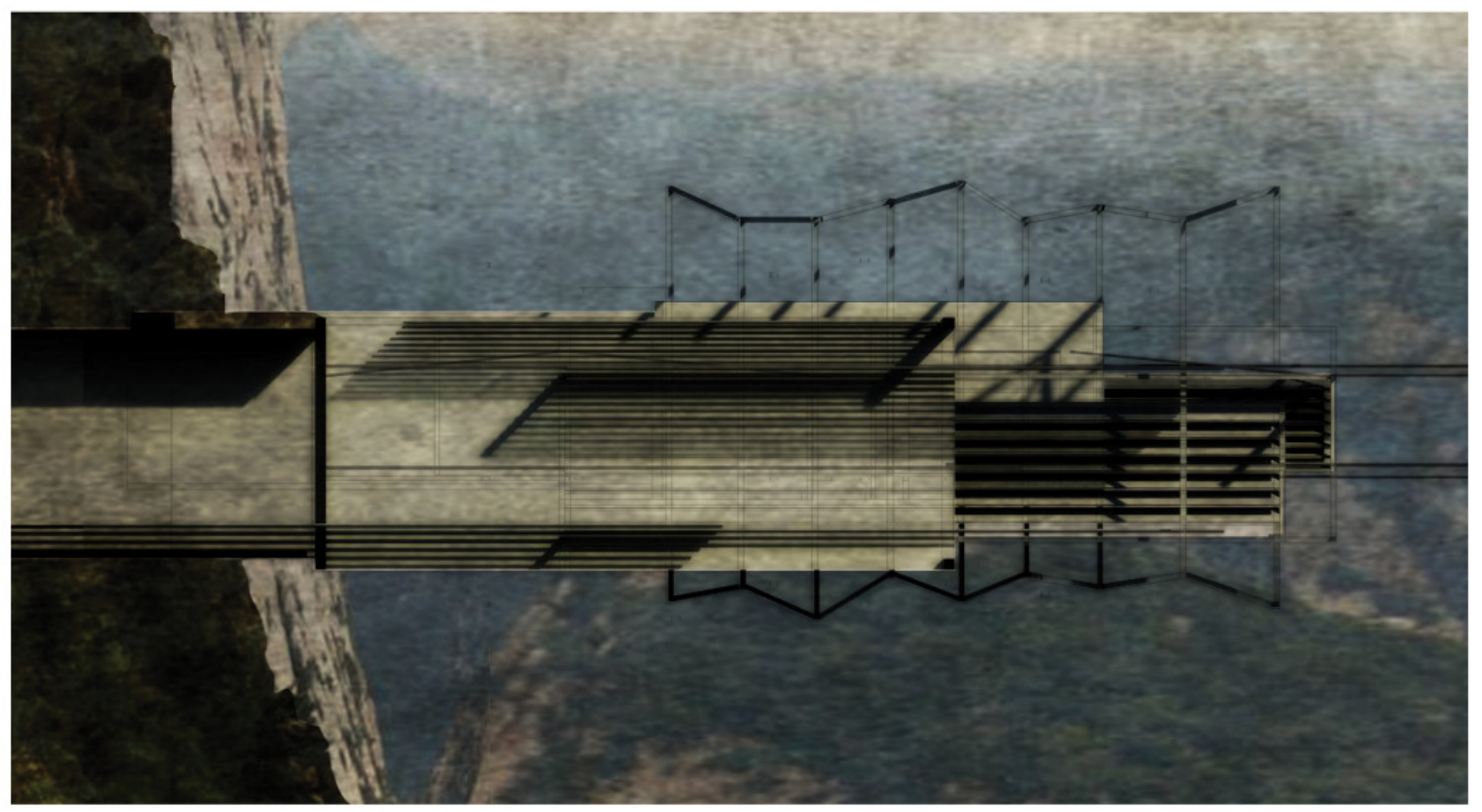

Figure 4.33 Section of Conceptual Outcome Generated from Image Group of Depiction 2.

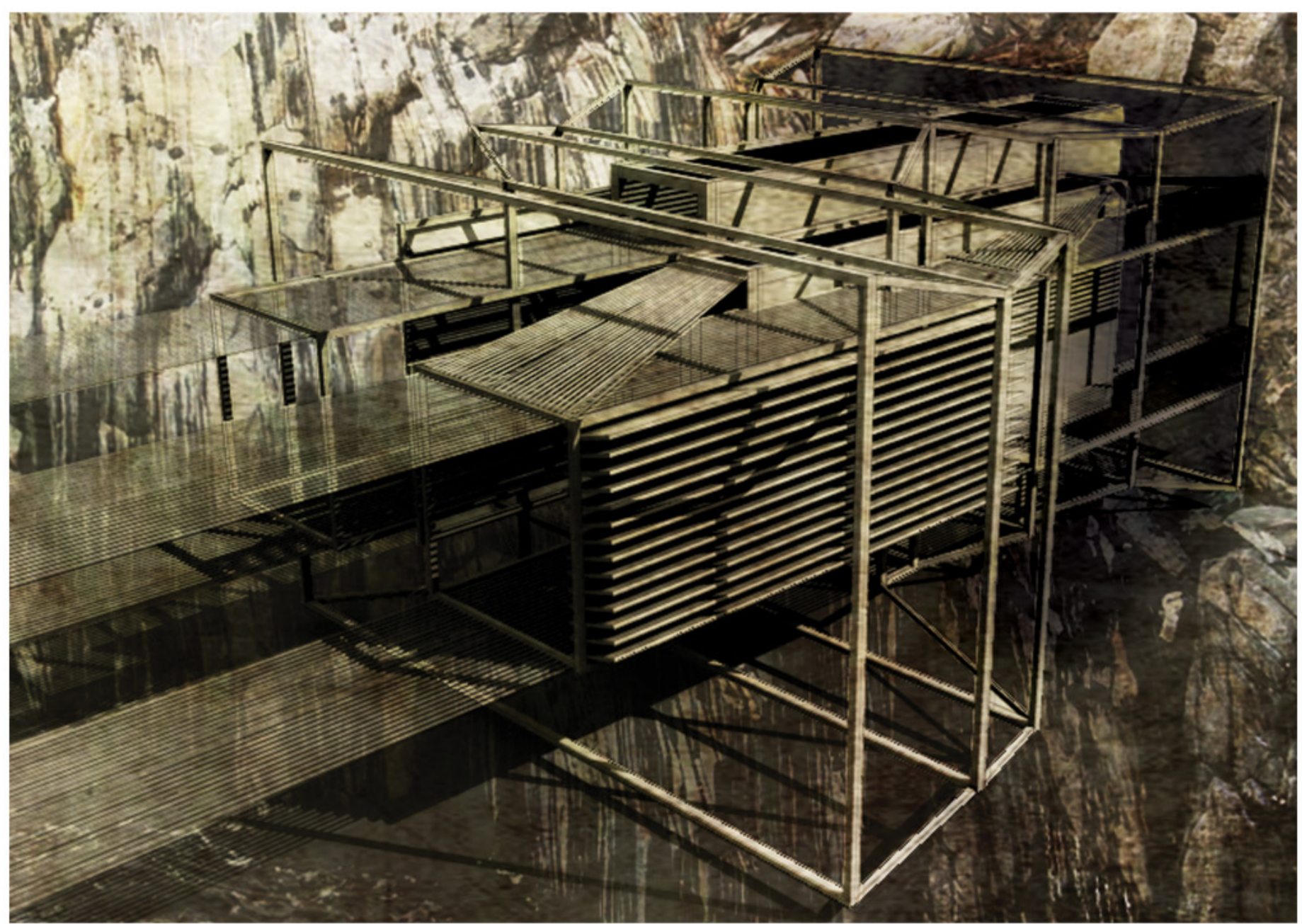

Figure 4.34 Exterior Perspective of Conceptual Outcome Generated from Image Group of Depiction 2. 


\section{Experiment Two}

The second design experiment uses Shirres' conceptual understanding of tapu and noa to read the architecture of a State House in Eastern Porirua. The site is within the group of houses investigated in the street elevation studies in Chapter three, and was chosen because the original house was burnt down and demolished (Fig.4.35-4.40). Like the images of the scoured landscapes from the original state housing developments within the area, the site with the house removed sits uneasily between its neighbours, and awaits the institution of newer and more appropriate architecture than the State House that was forcibly removed from the site.

The drawing of the site analysed the presence of, and relationships between, different tapu within the site that were established through years of occupation by the State House. Each layer of the drawing each analysed one of the following relationships of tapu established by the State House that exited on the site; namely the relationships:

(a) between the intrinsic tapu of people established within and between the living and bedroom areas (Fig.4.41)

(b) between the intrinsic tapu of people and of cultivated foods established by the entrance, consumption, and removal of food within the site (Fig.4.42)

(c) between the intrinsic tapu of the occupants and the outside world and visitors to the site established by the site and house entrances and the public passage and living areas within the house (Fig.4.43)

(d) between the intrinsic tapu of people as occupiers of the site and the land established through the physical architecture (Fig.4.44)

(e) between the four relationships identified above through their concurrent operation within site (Fig.4.45-4.46)

Following this, points within the site where tapu was cleansed were inscribed into the drawing (Fig.4.47). The points chosen to emphasise for this stage were again taken from traditional socio-spatial practices within Māori culture. First, the movement of water through the site was drawn, which within Māori culture and spatial practices such as the tangi, possesses the ability to cleanse or remove tapu. ${ }^{142}$ Second, the points within the house where food is consumed were drawn, as the consumption of cooked food within Māori culture is believed to confirm the tapu of people and their position within Te Aō Marama. ${ }^{143}$ Last, another layer was added that represented the cleansing of the site through the burning, demolishing, and removal of the State House from the site. ${ }^{144}$

The finished drawing, in essence, maps the operation of tapu and noa within the site from the time the State House was originally built on the site until today. By overlaying all of the layers, a complex map of the interaction, conflict, and resolution between different tapu within the site is created. In the same manner as the first experiment, the initial drawing was then read as an architectural plan and a digital model was constructed from it in order to generate a conceptual architectural outcome (Fig.4.48-4.51). 


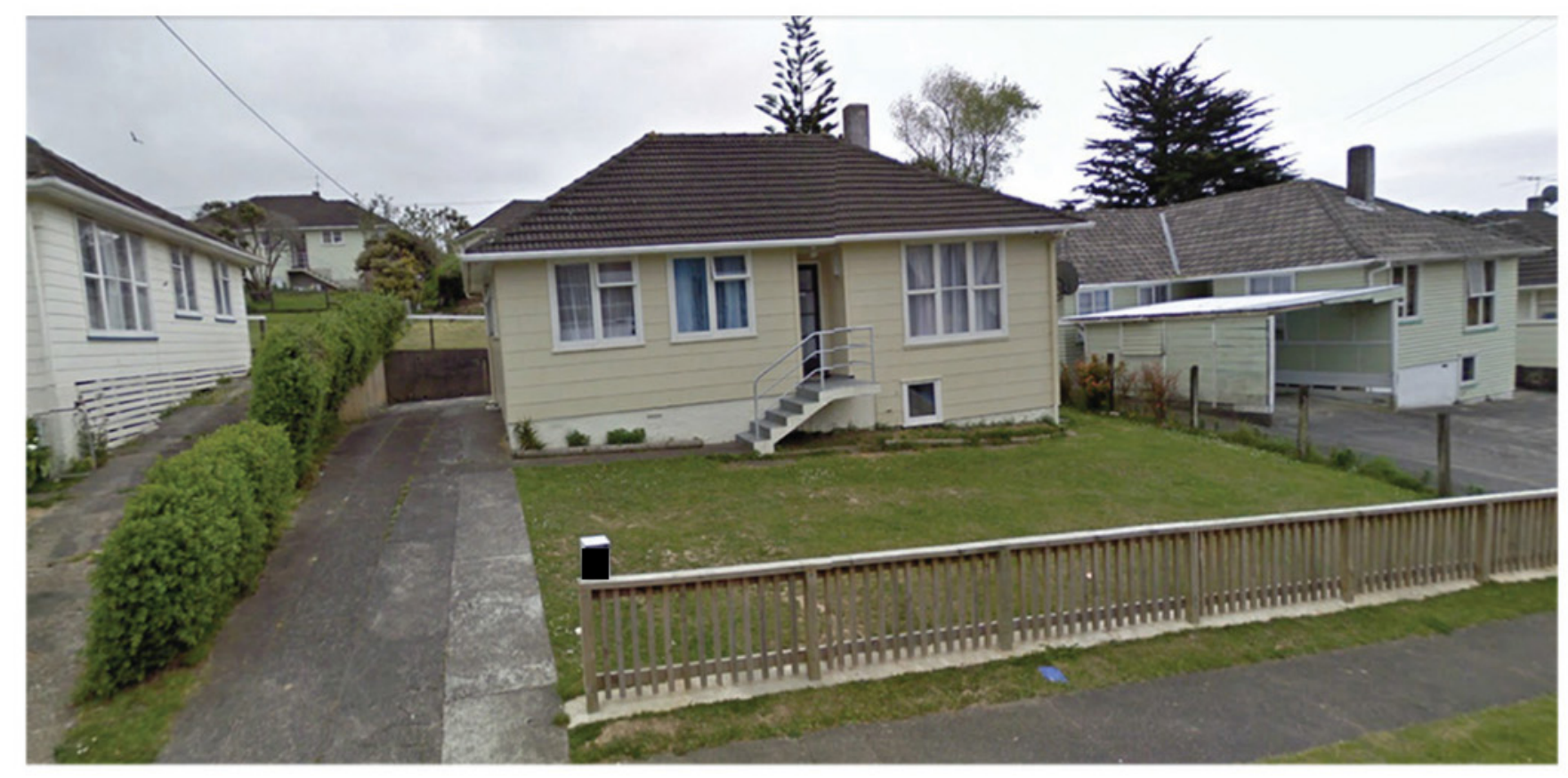

Figure 4.35 Exterior Perspective of Experiment Two's Site Pre-removal of the State House. Image dated November 2009.

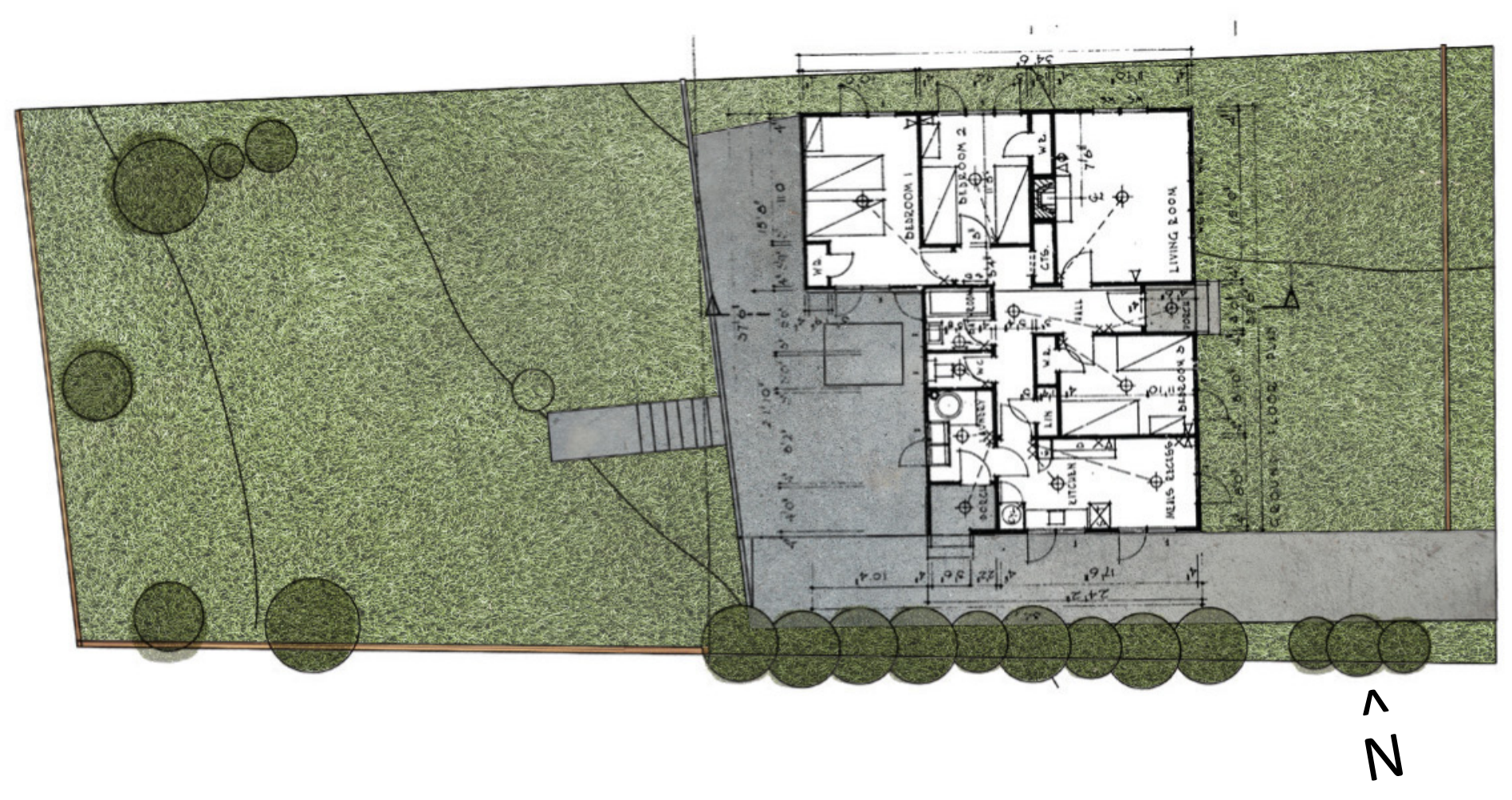

Figure 4.36 Site plan of Experiment Two's Site Pre-removal of the State House. 


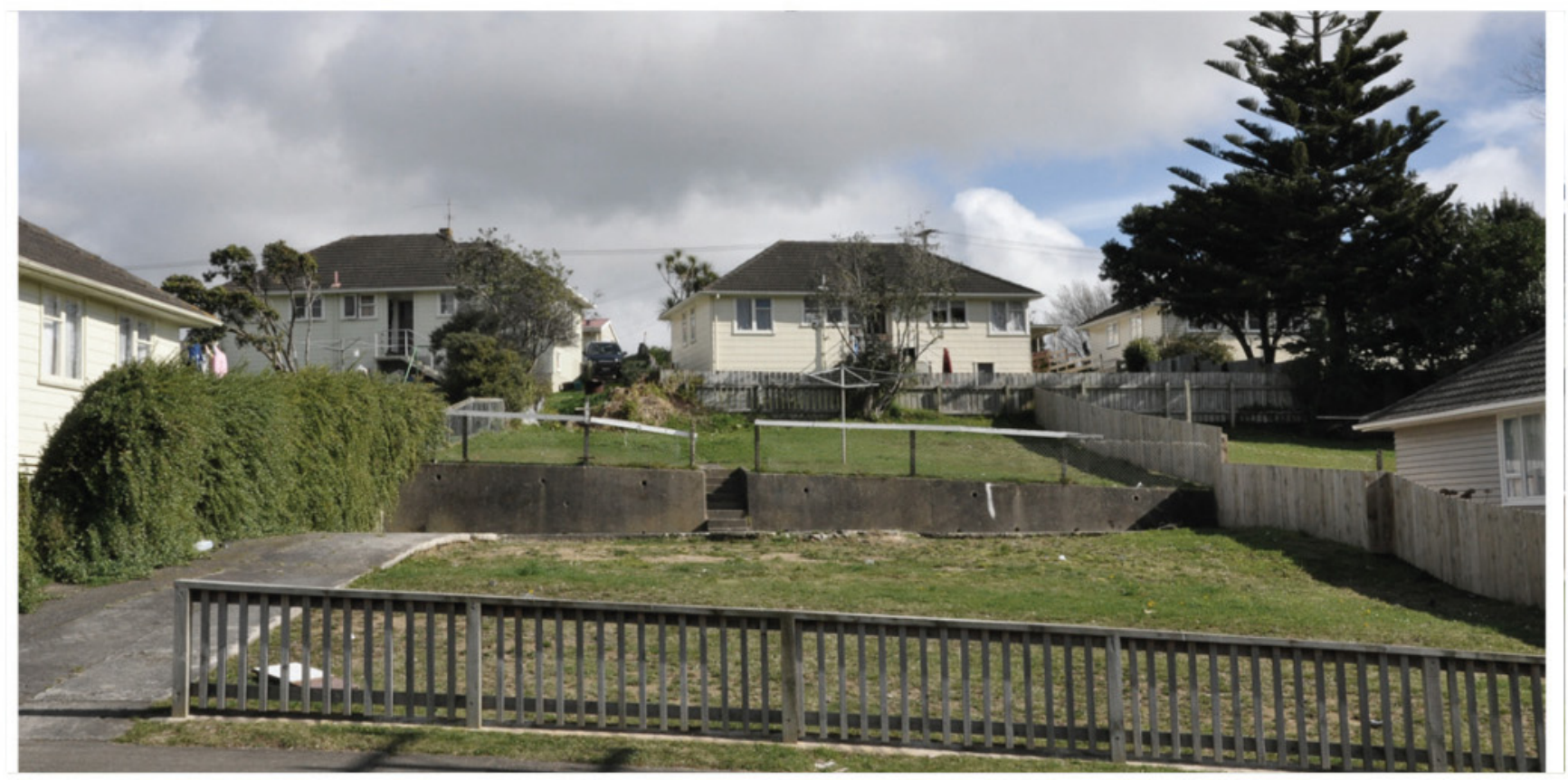

Figure 4.37 Exterior Perspective of Experiment Two's Site Current Condition.

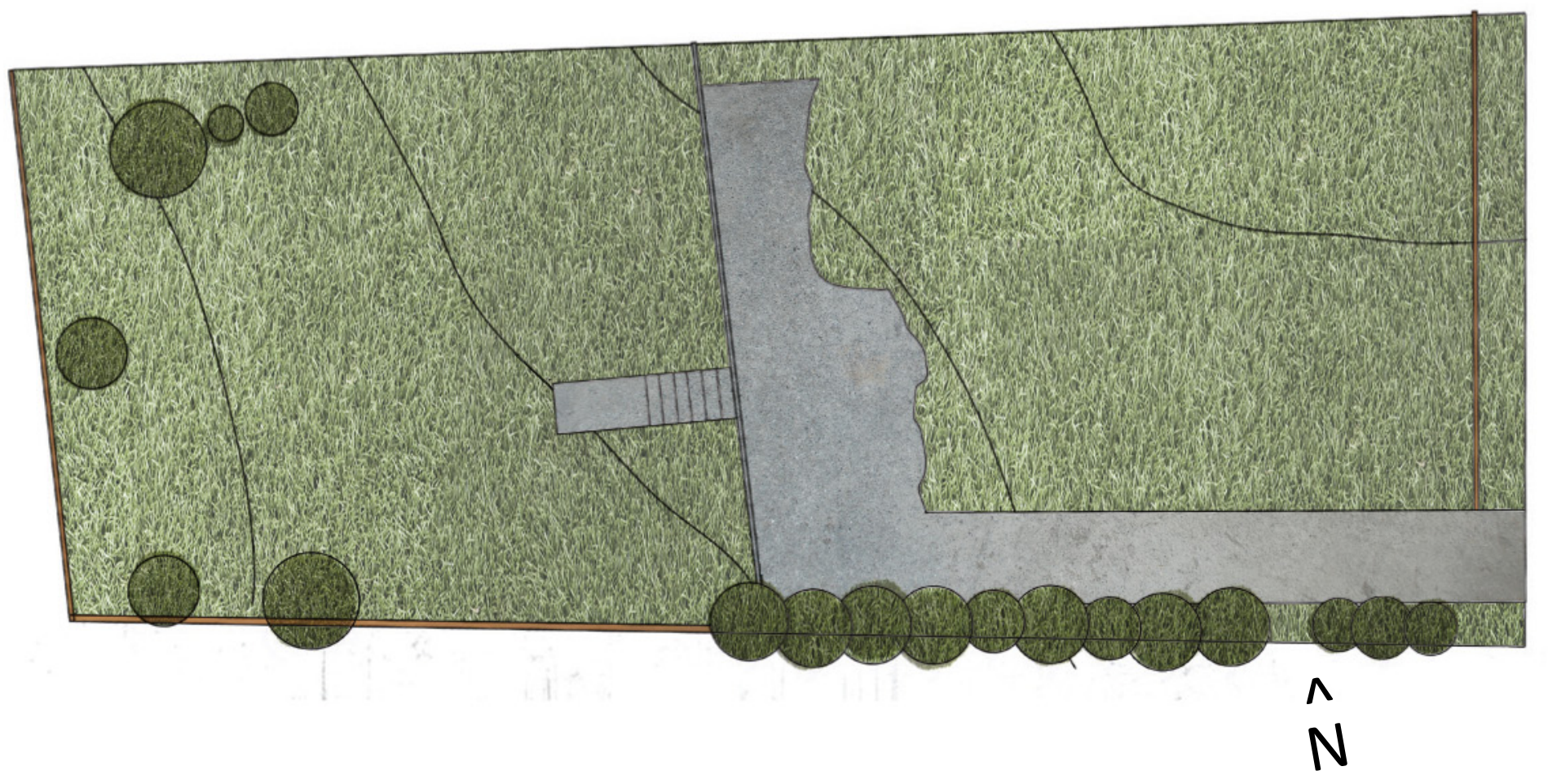

Figure 4.38 Site Plan of Experiment Two's Site Current Condition. 


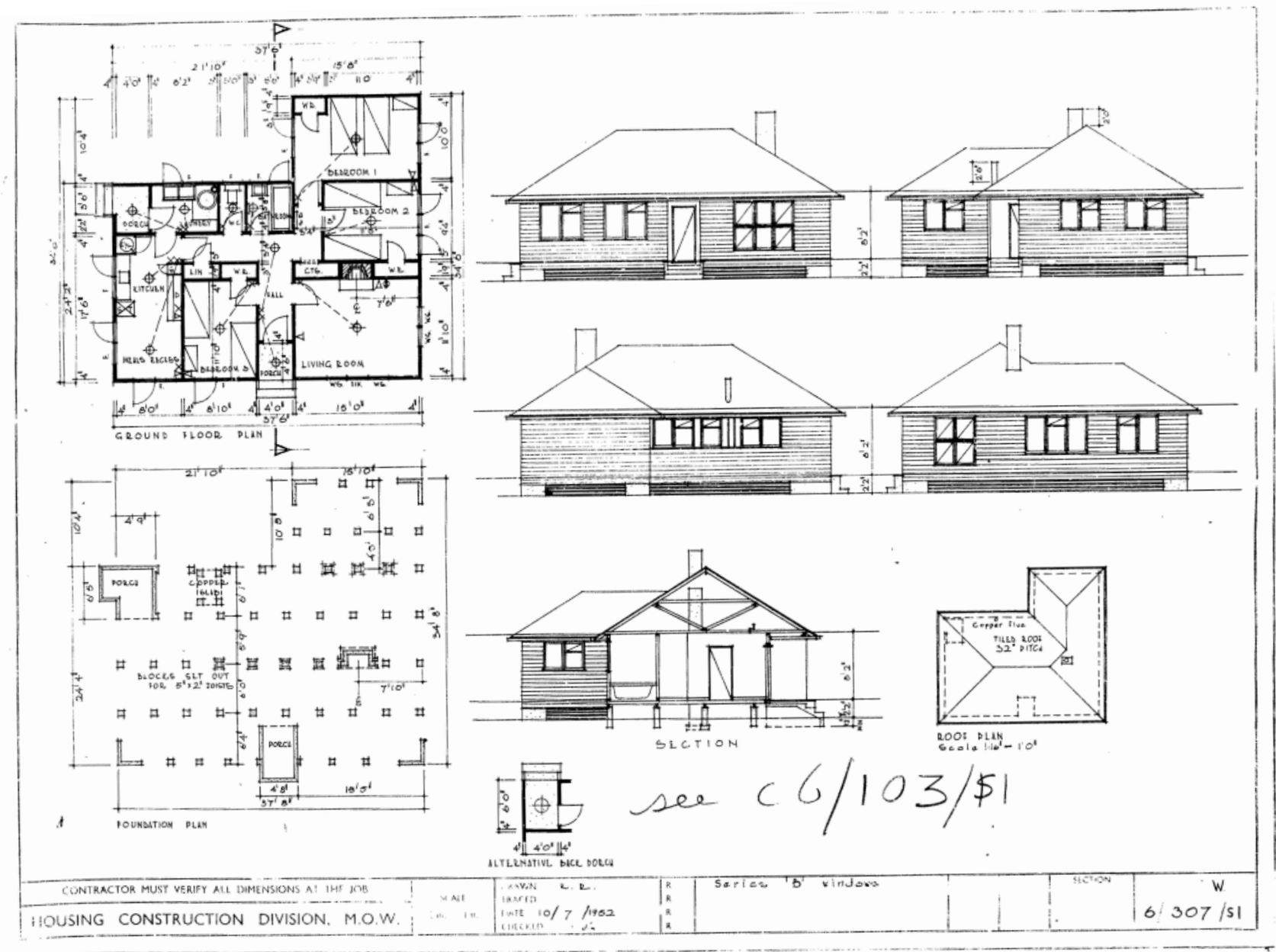

Figure 4.39 Plan Card of Experiment Two's Site Original State House

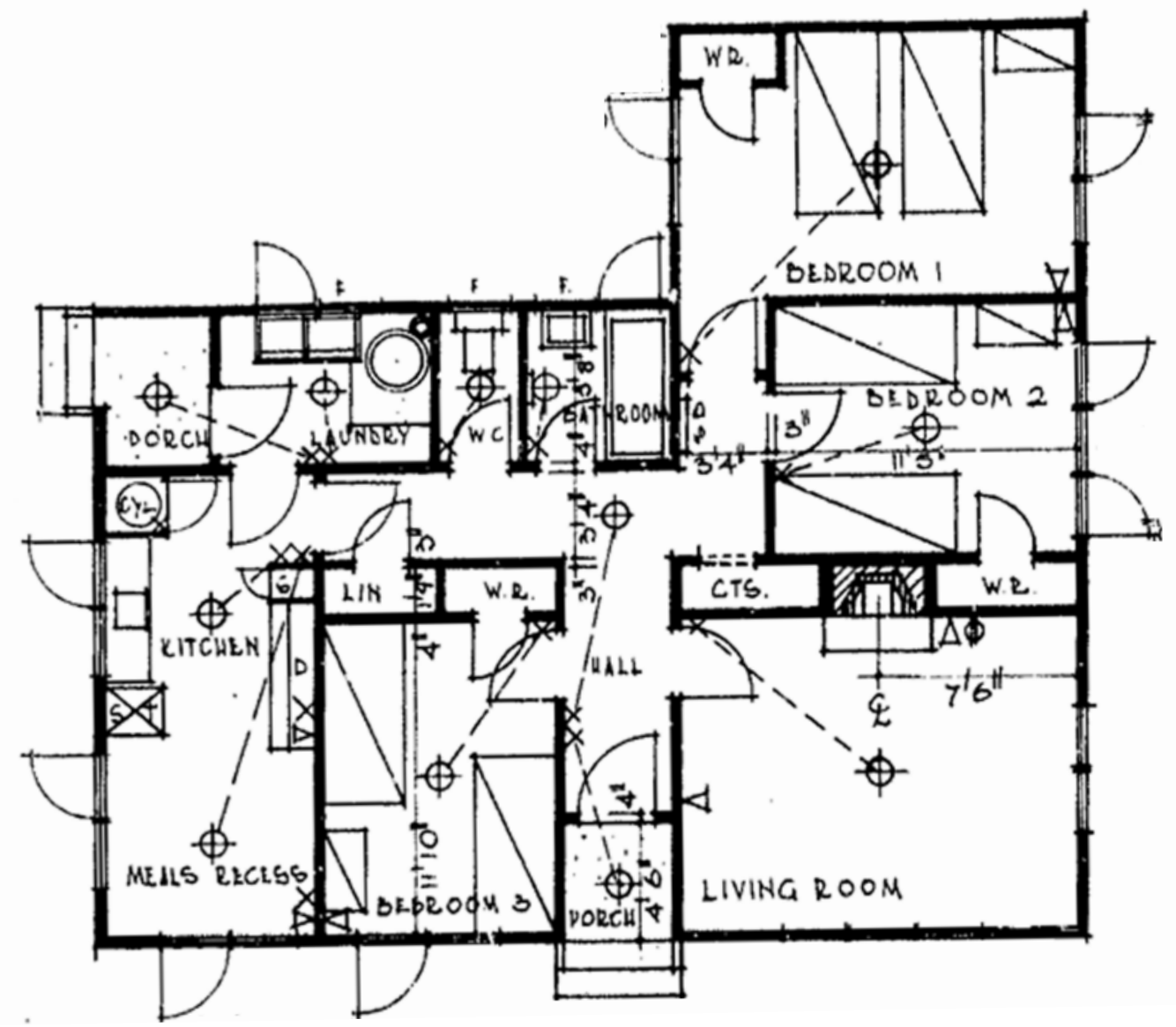

Figure 4.40 Enlarged Plan of Experiment Two's Site Original State House 


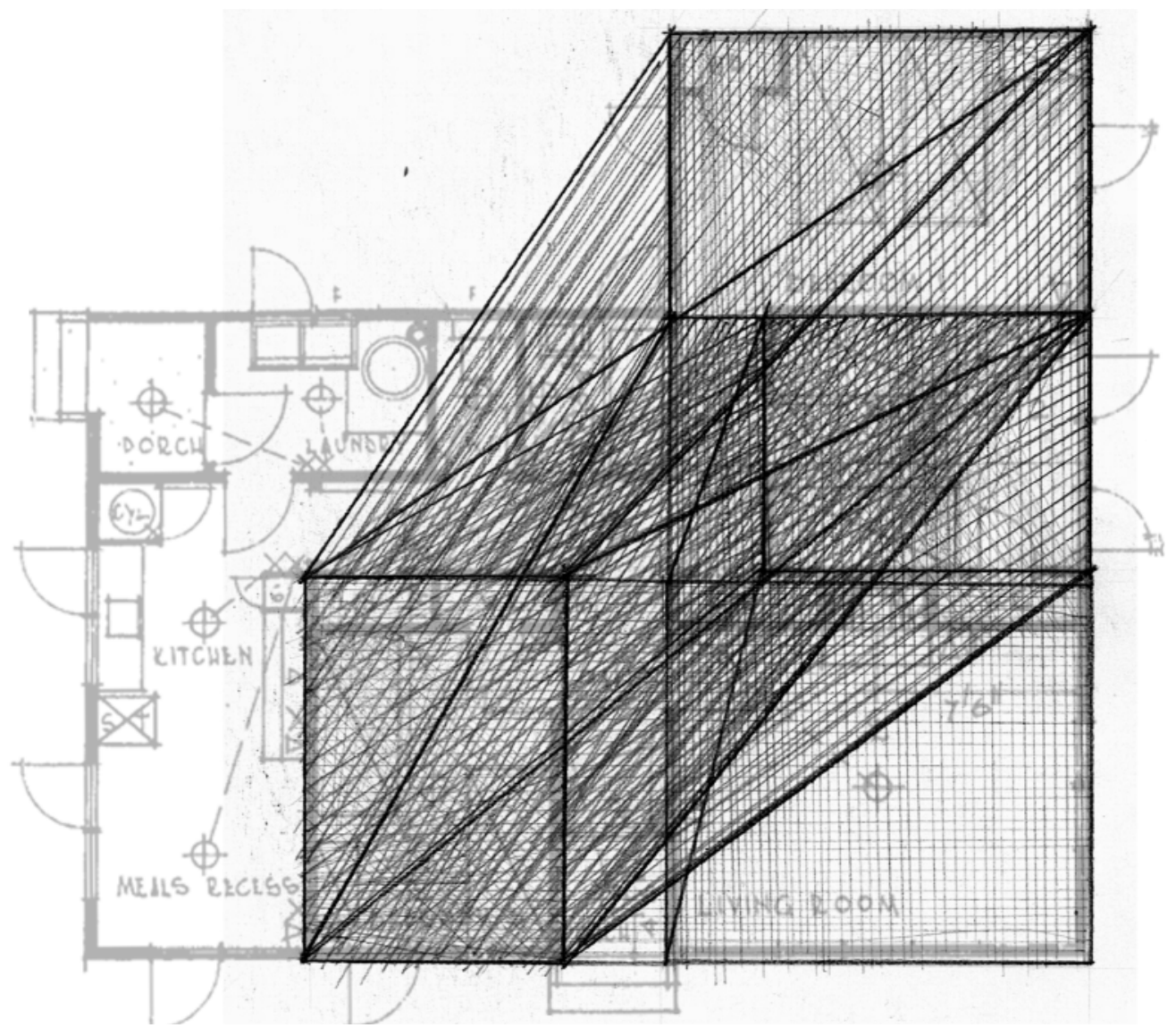

Figure 4.41 Drawing Analysing the Relationship between the Intrinsic Tapu of People Within and between the Living and Bedroom Areas of the Original House. Author's own drawing 


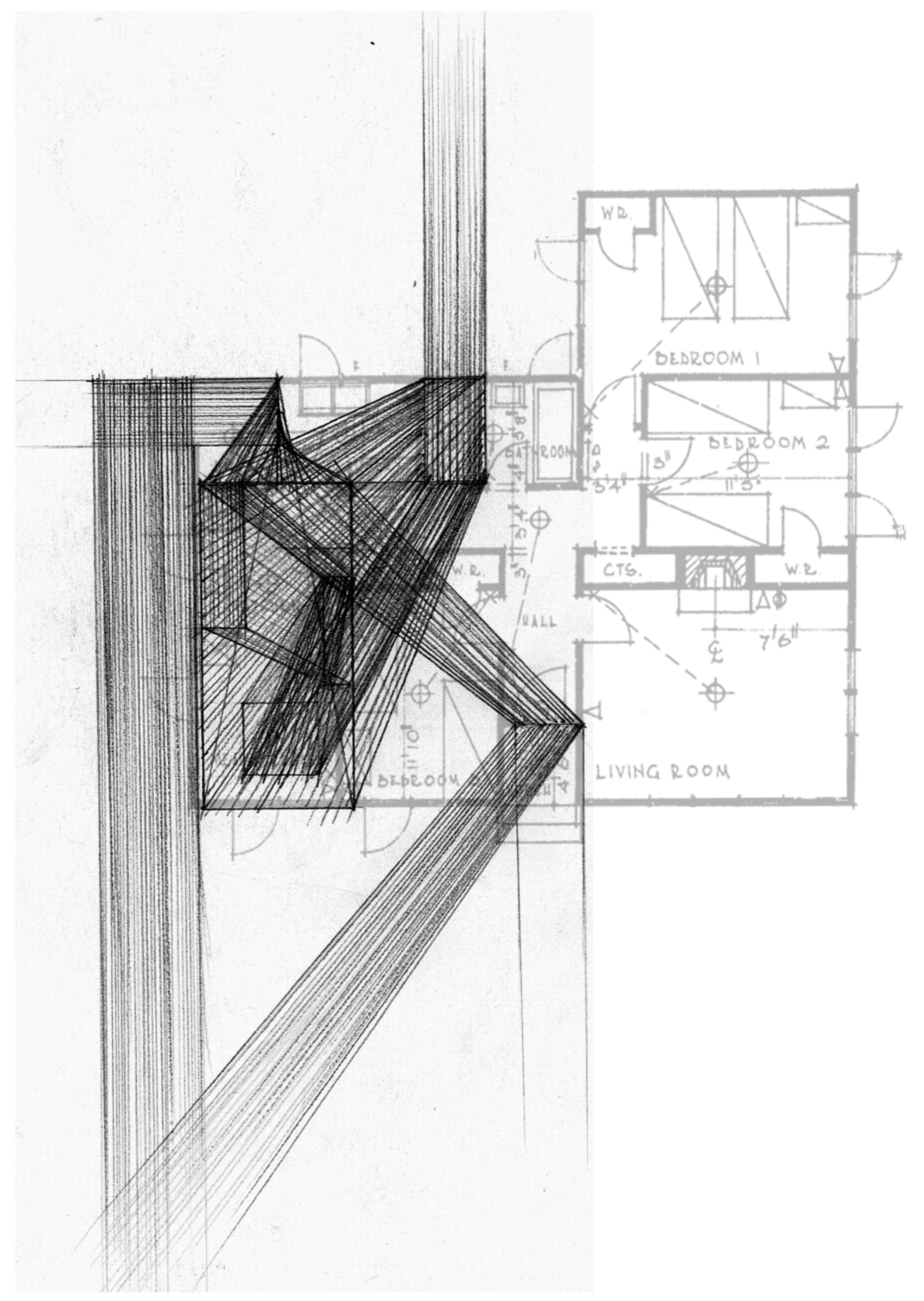

Figure 4.42 Drawing Analysing the Relationship between the Intrinsic Tapu of People and of Cultivated Foods Established by the Entrance, Consumption, and Removal of Food Within the Site. 


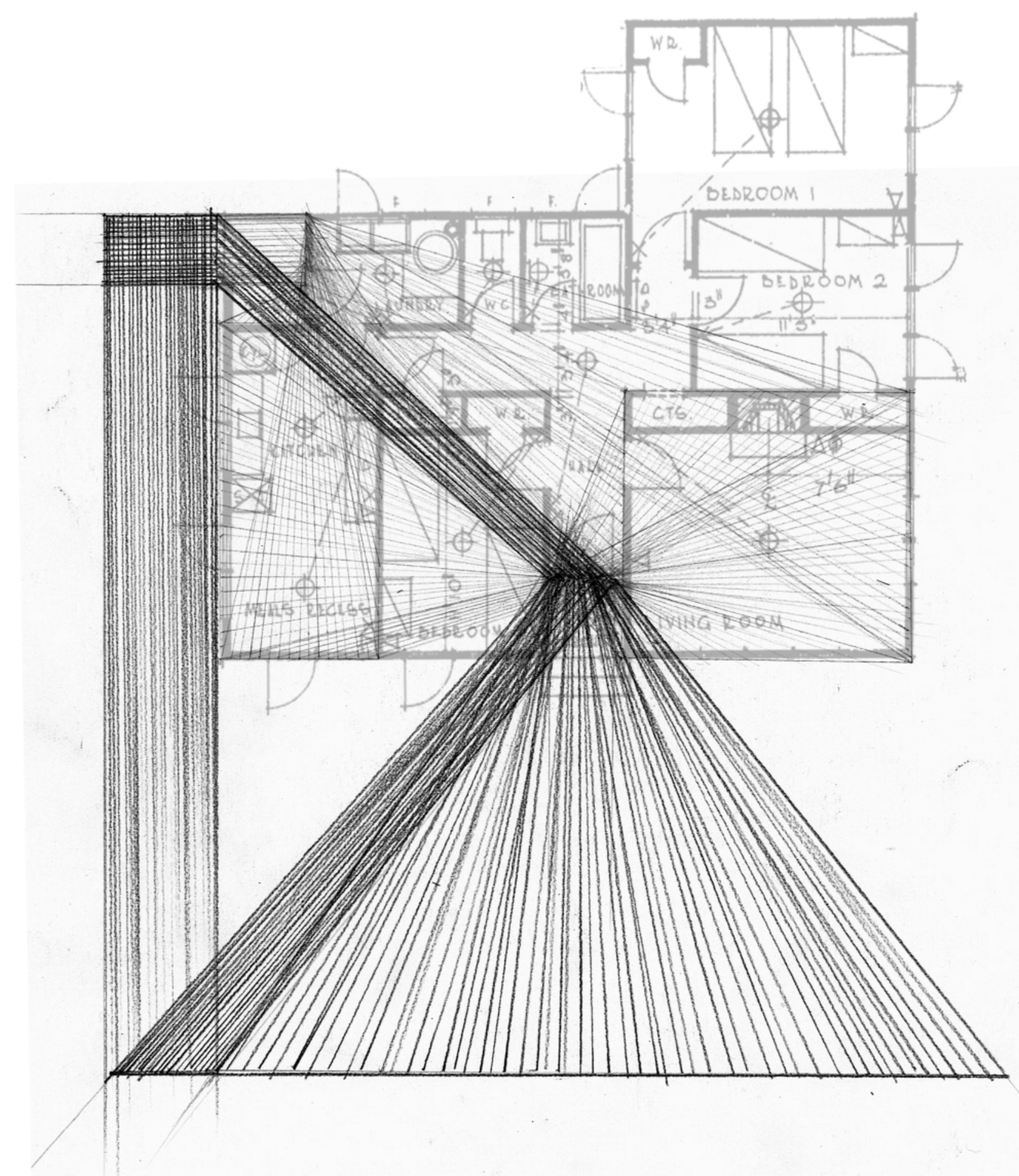

Figure 4.43 Drawing Analysing the Relationship between the Intrinsic Tapu of the Occupants and Visitors to the Site Established by the Site and House Entrances and the Communal Passages and Living Areas Within the Site. 


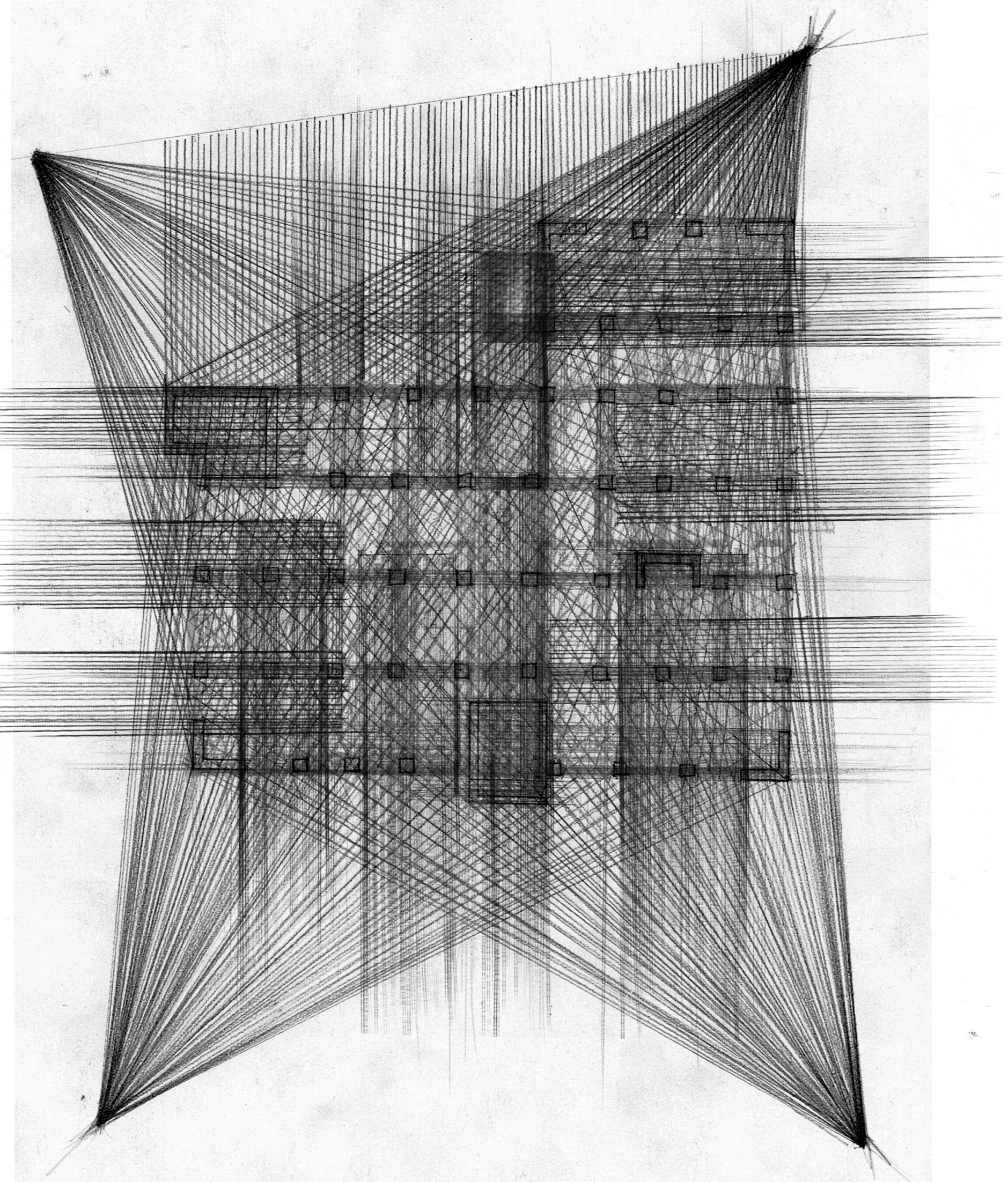

Figure 4.44 Drawing Analysing the Relationship between the Intrinsic Tapu of People as Occupiers of the Site and the Land Established Through the Physical Architecture. 
Joshua Blandford. Possibilities Towards a Post-Colonial Architecture in Residential New Zealand

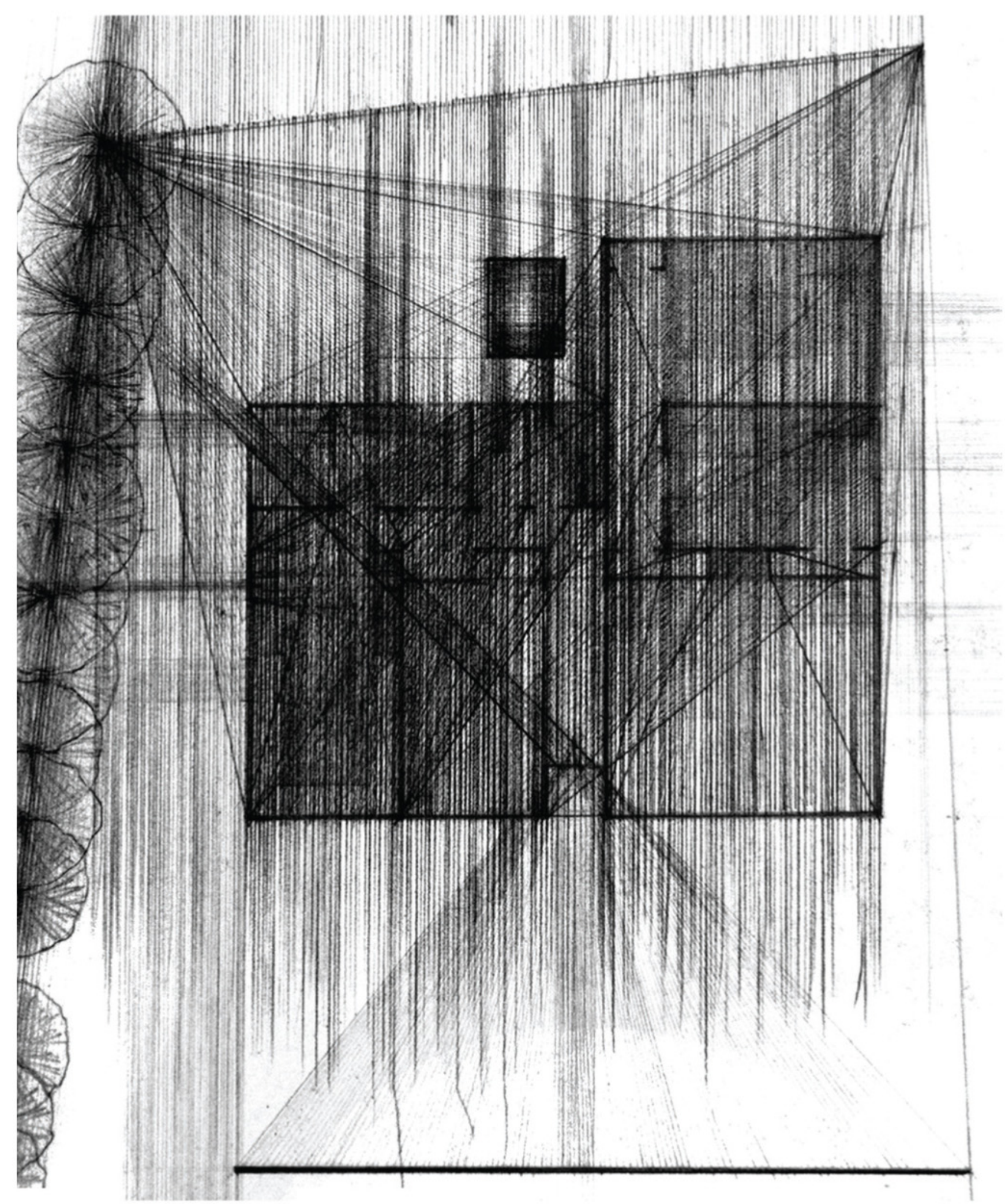

Figure 4.45 Drawing Analysing the Relationship between the Tapu explored in Figures 4.11-4.14. 


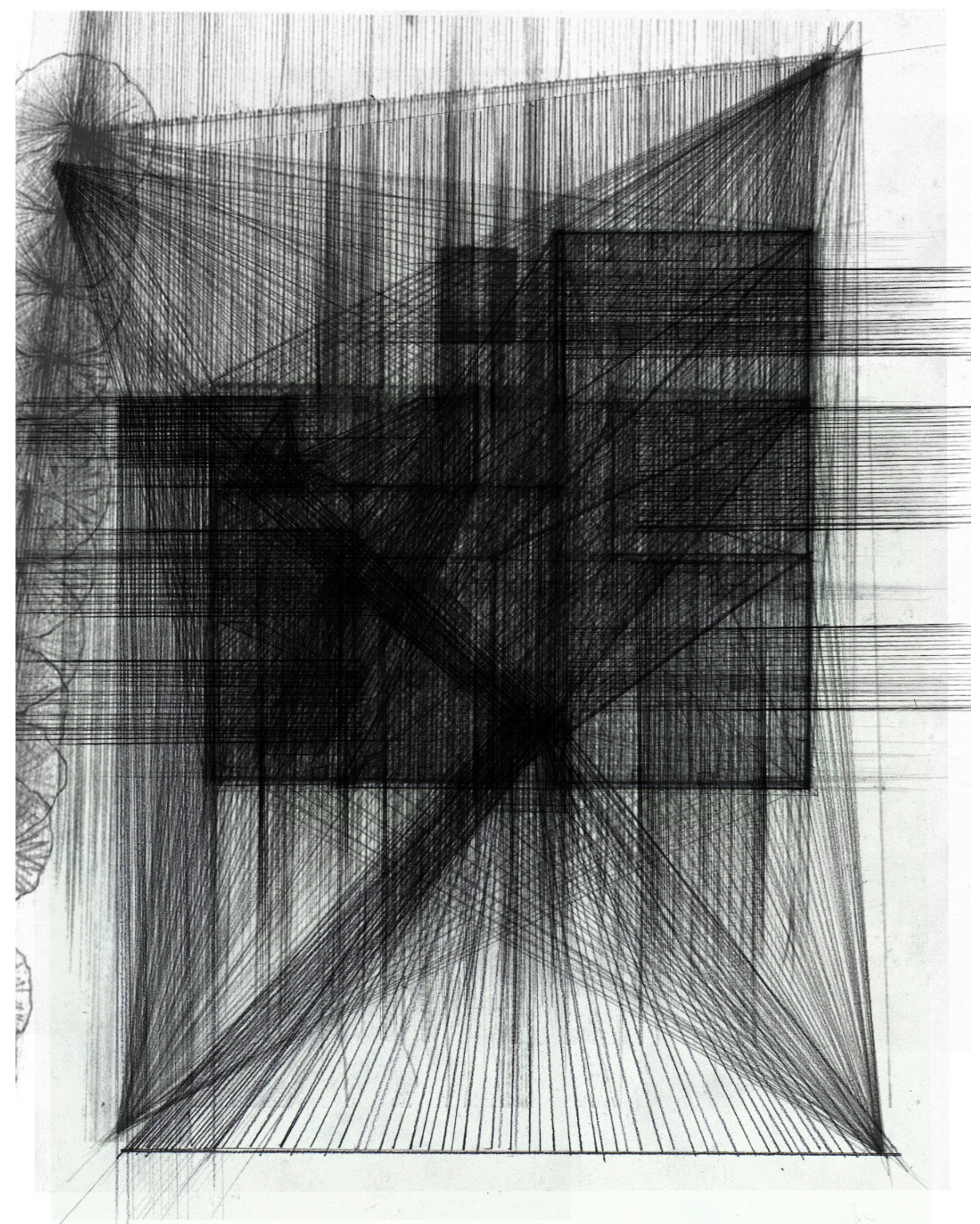

Figure 4.46 Tapu Map Overlay of Figures 4.11-4.15. 
Joshua Blandford. Possibilities Towards a Post-Colonial Architecture in Residential New Zealand

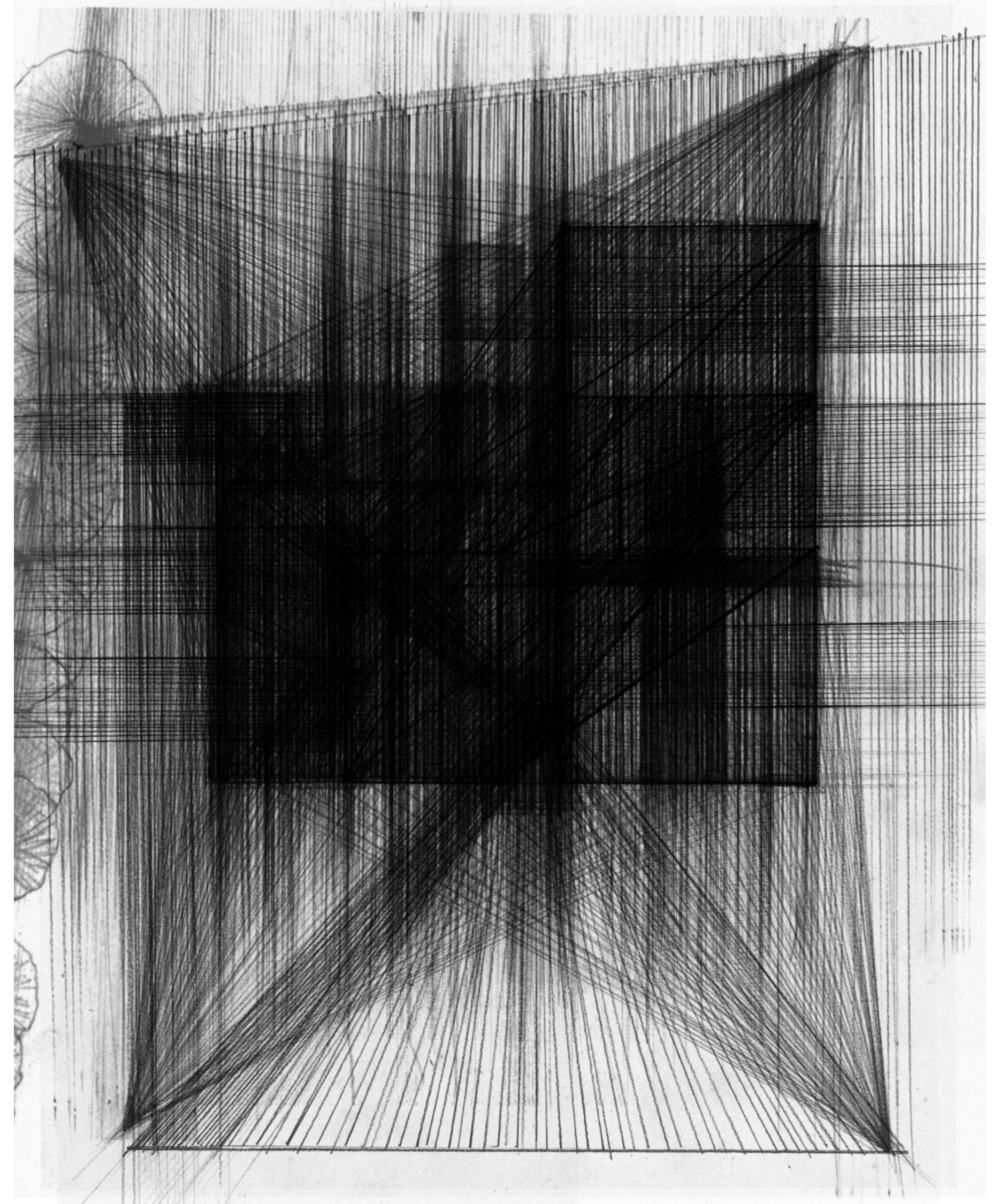

Figure 4.47 Tapu Map Overlay of Figures 4.11-4.15, with areas where tapu is cleansed within the site inscribed into the drawing. 


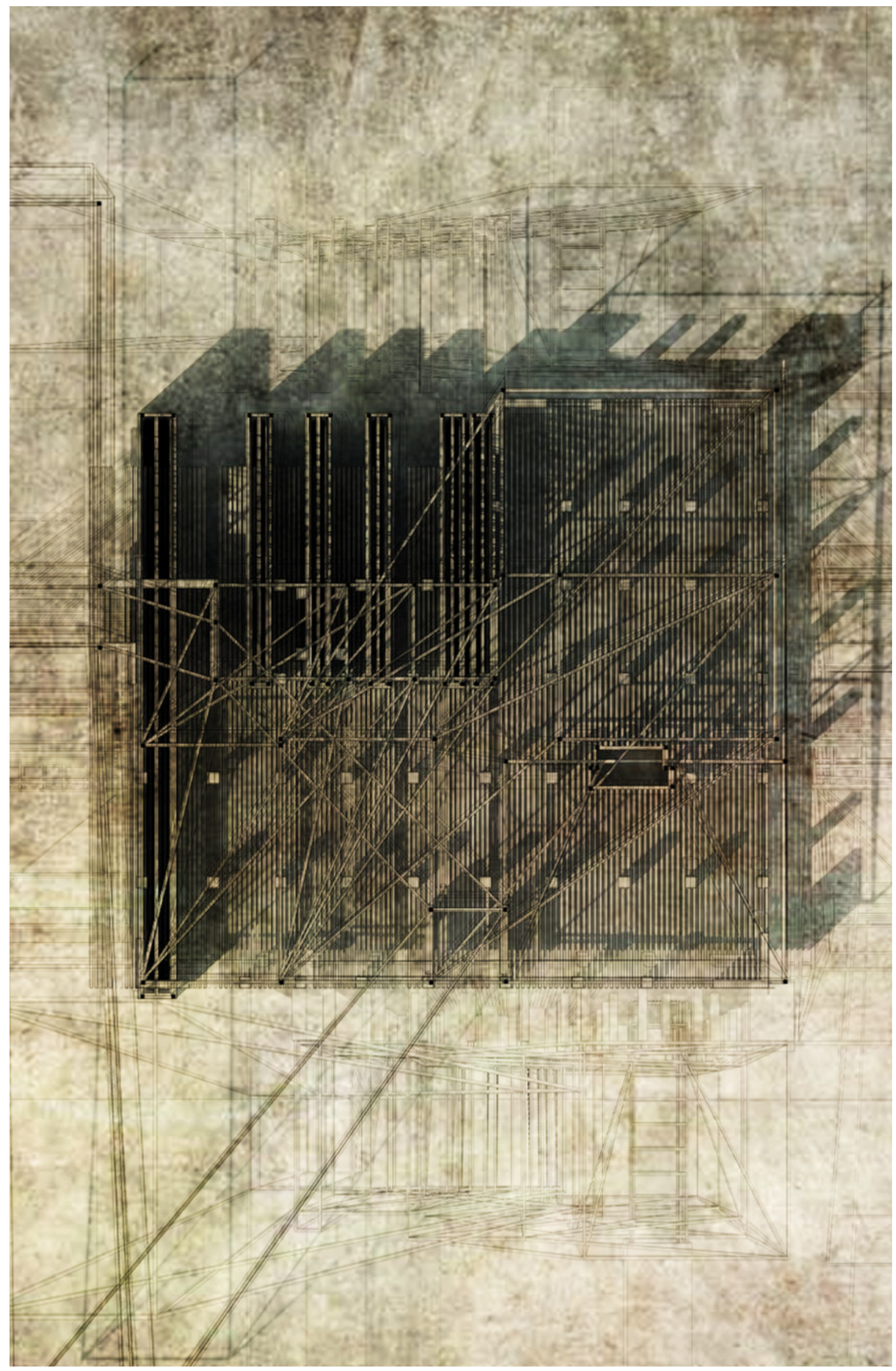

Figure 4.48 Plan of Conceptual Outcome Generated from Conceptual Image Analysing the Presence of Tapu and Noa within Experiment Two's Site. 


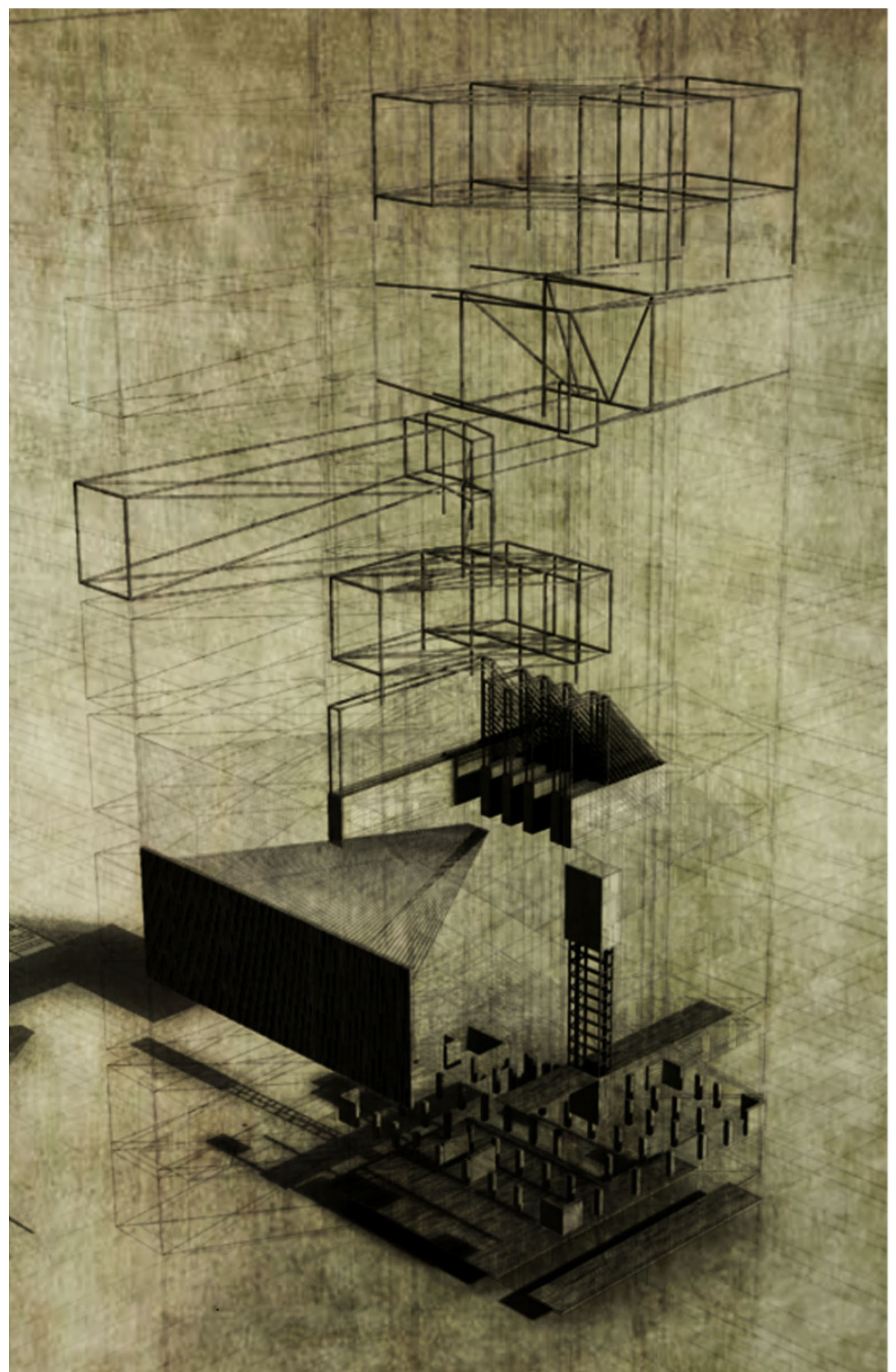

Figure 4.49 Exploded Isometric of Conceptual Outcome Generated from the Analysis of the Presence of Tapu and Noa within Experiment Two's Site. 


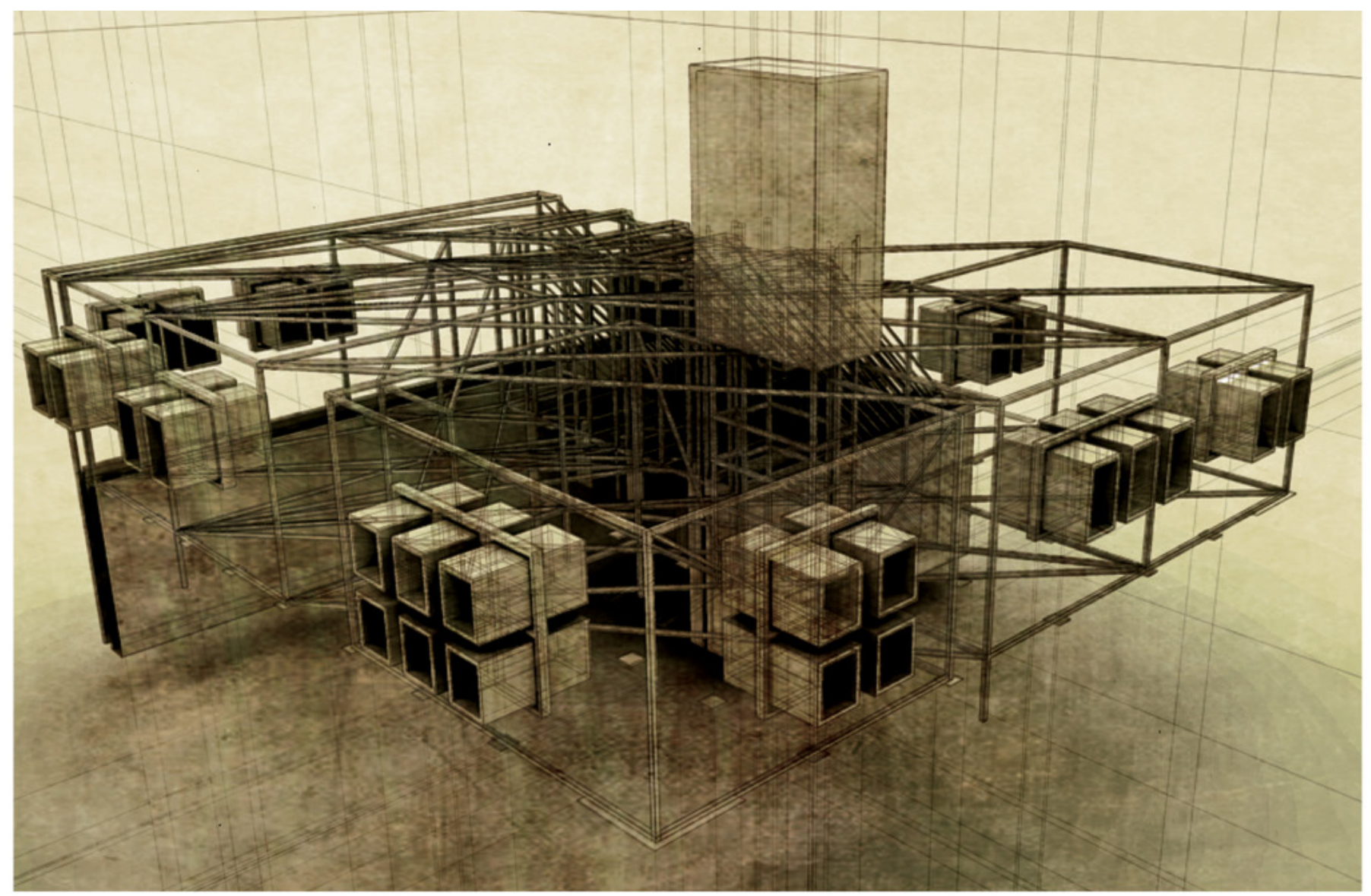

Figure 4.50 Perspective of Conceptual Outcome Generated from Conceptual Image Analysing the Presence of Tapu and Noa within Experiment Two's Site.

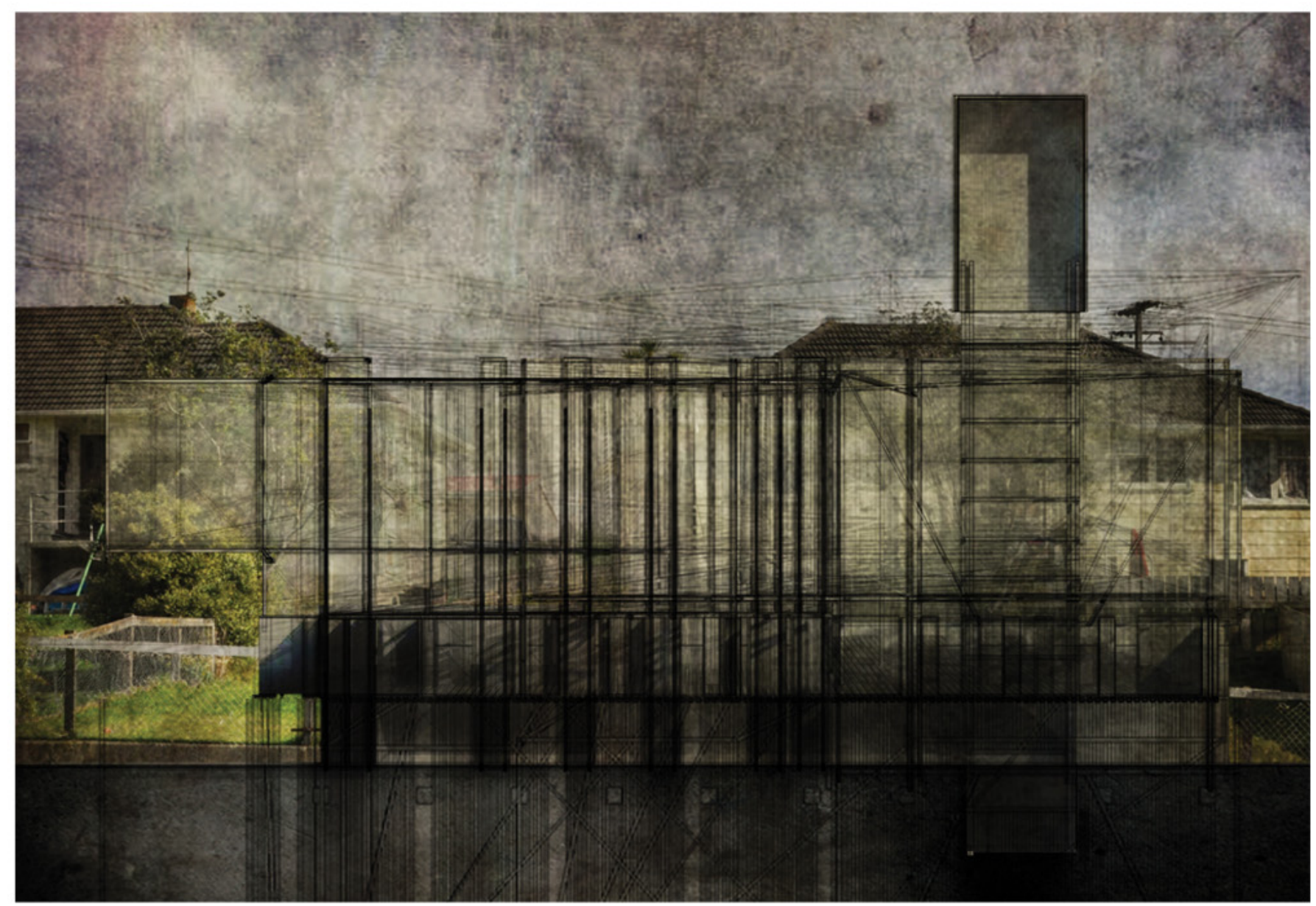

Figure 4.51 Section of Conceptual Outcome Generated from Conceptual Image Analysing the Presence of Tapu and Noa within Experiment Two's Site. 
Like the outcome from the first experiment, the reliance upon an historical interpretation of a traditional narrative makes it difficult to judge as an outcome suitable for contemporary New Zealand inhabitants. Likewise, the experiment assumed that the spatial practices that operated within the State House followed those prescribed by the architectural plan. In some aspects this assumption is most likely correct; for example, the points of the house where water runs through and where contact between people and water is made. However, in other aspects there is some degree of uncertainty regarding the use of spatial practices. For example, it was assumed that food was consumed within the dining area marked in the plan, whereas in reality the inhabitants may have eaten elsewhere.

The experiment was successful nevertheless in establishing a new architectural position that is related to, but not bound by, either of the original positions. Although a traditional conceptual understanding of tapu and noa was initially used to read the architecture, the process of the experiment shifted it from being a practised concept through events and ritual (i.e. tangi, hui) into something which generated formal architectural outcomes. Likewise, although the State House plan was used as the starting point for the design, the unconventional reading of the plan shifted the outcome away from conventional notions of expectations of residential architecture. The outcome is, therefore, not only difficult to read as a pure physical manifestation of tapu and noa, but also unconventional in terms of the established residential house typology in contemporary New Zealand society. 



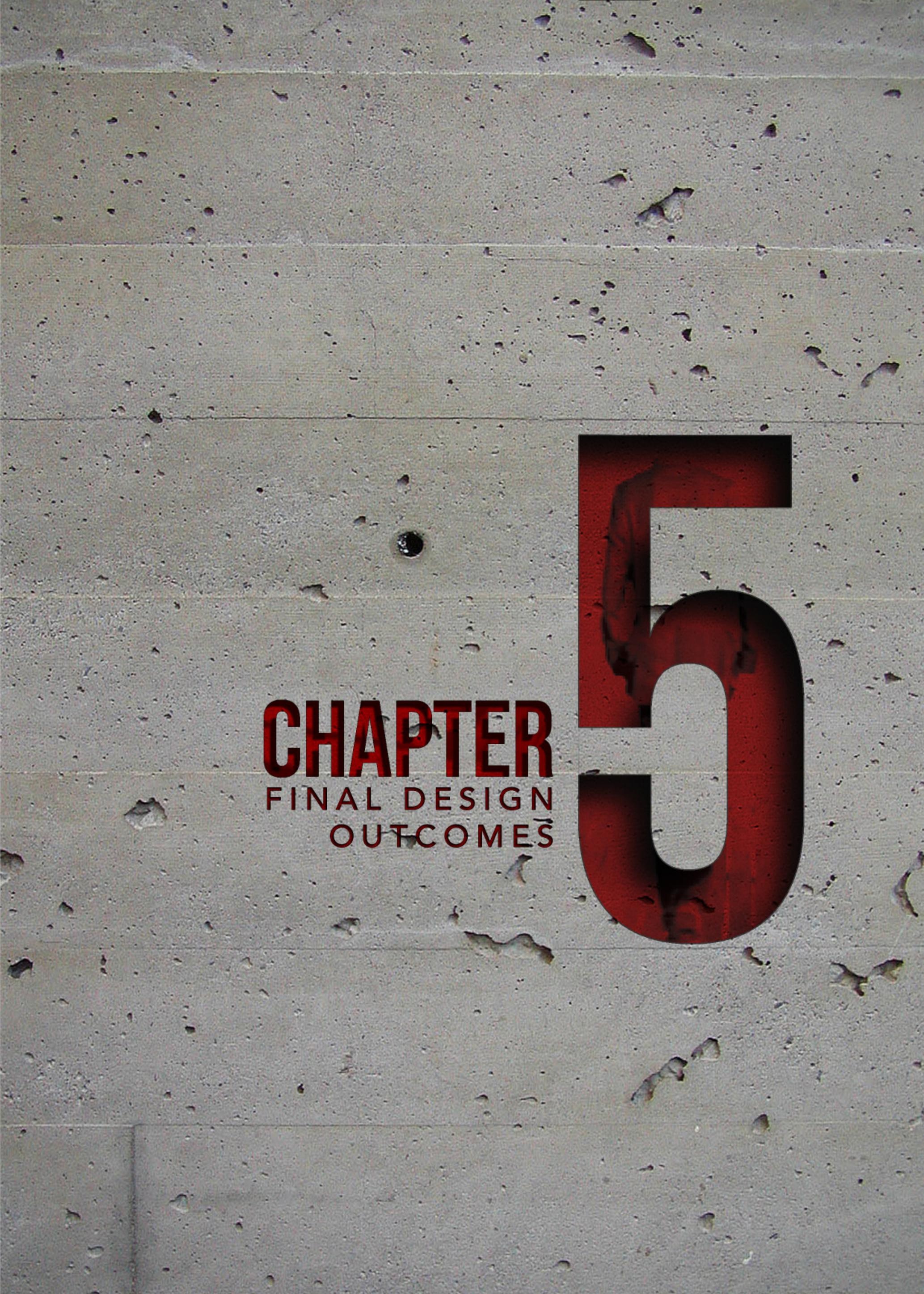




\section{Chapter Five: Description and Analysis of Final Design Outcomes}

\section{$\underline{\text { Design One }}$}

The first design developed conceptual outcome number two, which was generated in Chapter four from the depiction of the front entrance of the wharenui. The functional programme, spatial qualities, materials, and structural and constructional relationships were initially developed through a reading of the cultural narratives associated with the wharenui identified by Austin, namely:

- Openness and enclosure

- Public to private

- $\quad$ Light to dark

- Conflict to Resolution

The functional programme within the house was also developed through referencing the two primary tapu identified by Shirres, the intrinsic tapu of the kumara and the intrinsic tapu of people on each side of the house. The drawings generated within the initial experiment were read as a series of thresholds between these functions and spatial qualities (Fig.5.1-5.2). Therefore, at one end of the architecture are the most private functions, which are also the most enclosed, resolved/calm, and darkest spaces (Fig.5.3-5.5). As the distance from this end increases, the functions become more public, and the qualities of the spaces lighter, more open, and more conflicting or dynamic in terms of their constructional and structural relationships (Fig.5.6-5.10).

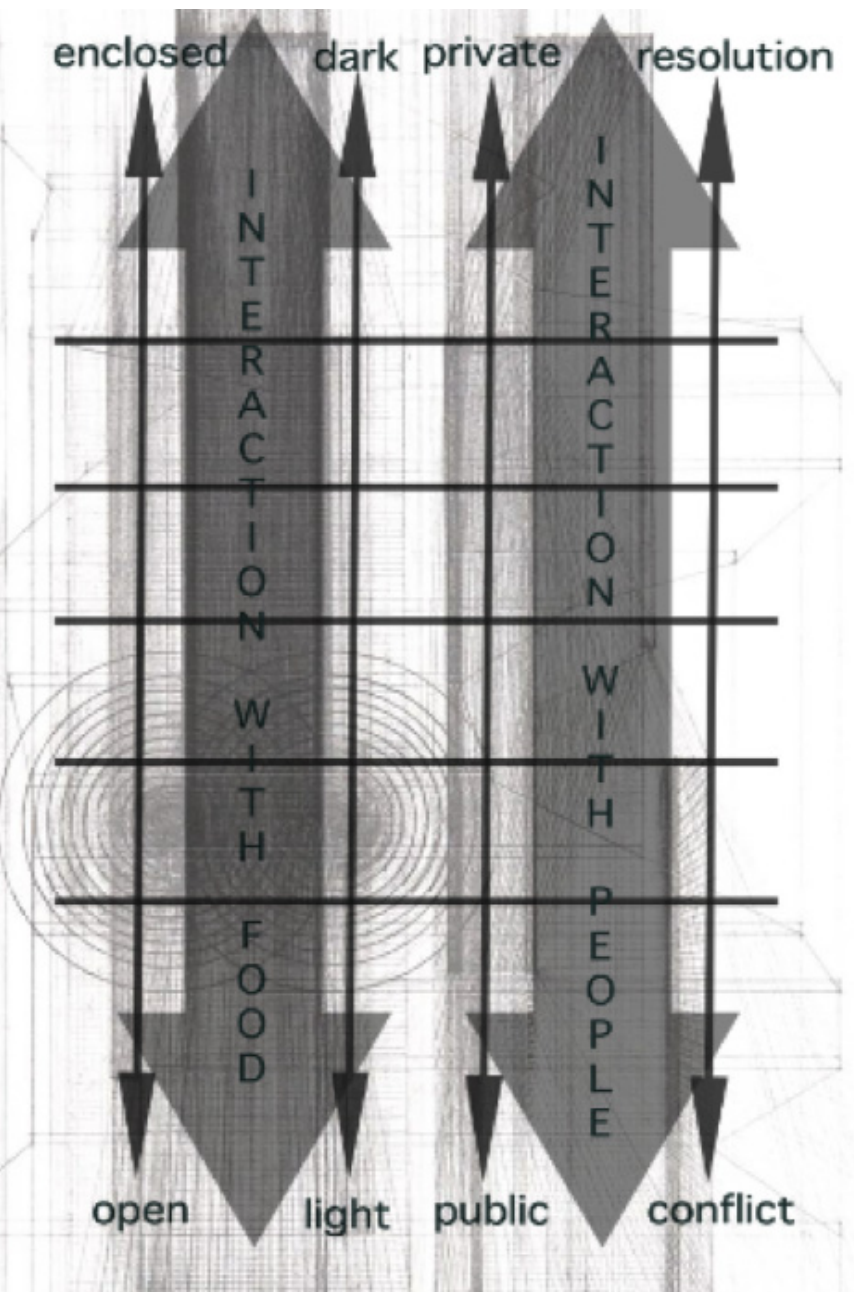

Figure 5.1 Diagram of Programmatic and Spatial Qualities of Design One. The house operates as a threshold between the spatial qualities noted within this diagram. The house is also split so that each side of the house focuses upon an interaction between the two primary intrinsic sources of tapu identified by Shirres. Therefore on one side of the house the functions signify the interaction between the tapu of Tumatauenga (People) and Rongomatane (Cultivated food), and on the other side the interaction between the tapu of individual people as ancestors of Tumatauenga, with the tapu of wider groups of people. 


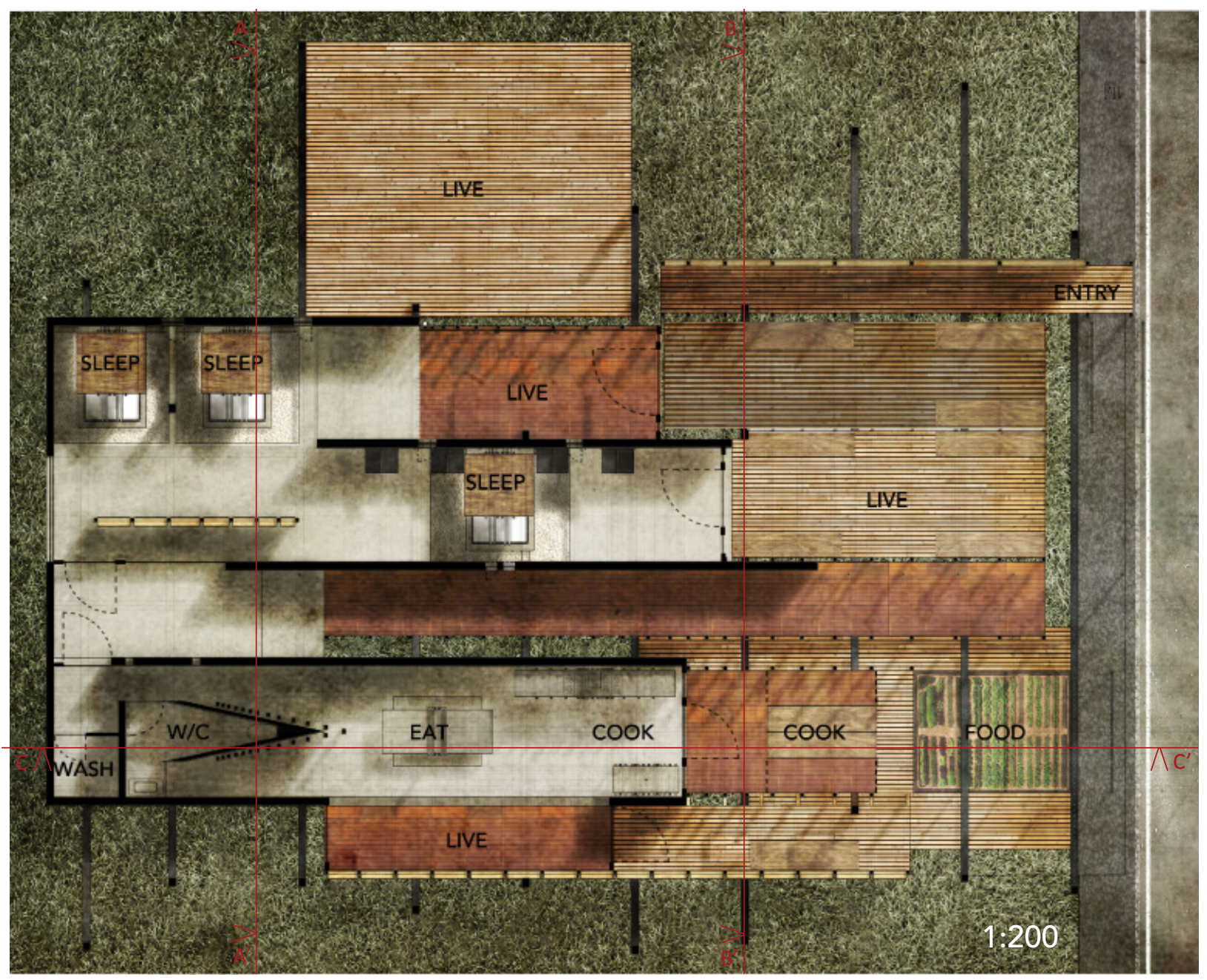

Figure 5.2 Plan, Design One. The plan 政 of functions within the house, as well and formal changes in ord to shift the spatial qualities within eac

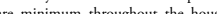
instead threshold is initiated throus hanges in material and spatial quality 


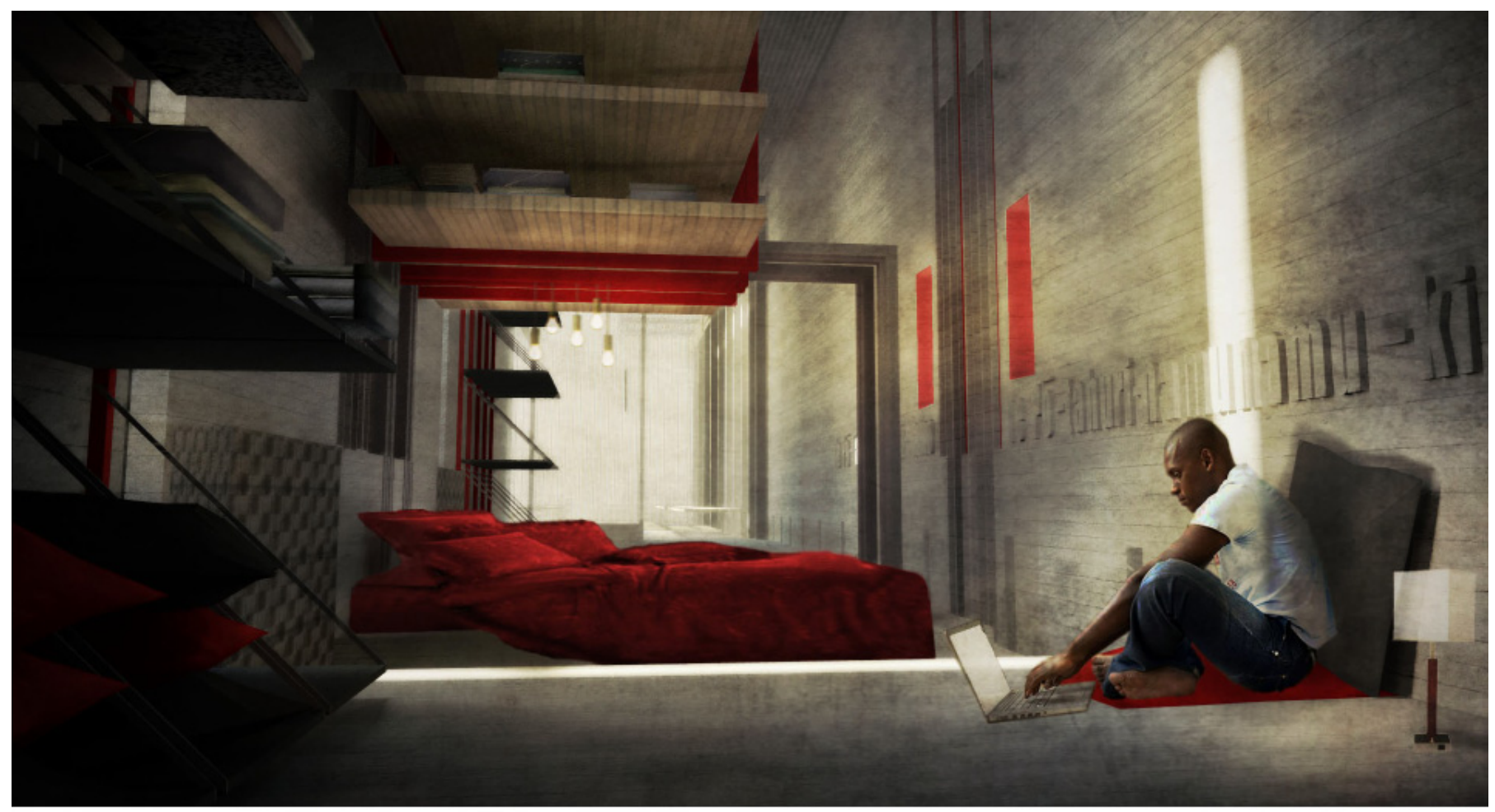

Figure 5.3 Interior Perspective of Parents Bedroom, Design One. This space is screened off but not completely removed from the children's bedroom area. The panel shelving above the bed, and the beams and columns supporting them, convey the notion that the bed is hung from the ceiling, and the bed platform is recessed below the floor level, to indicate the interaction that occurs between the states of Te Ao Marama and Te Po at dawn and dusk, as well as when the occupants sleep. This is also indicated by the written inscription on the right hand wall, which reads on the lighter northern side Te Pō Tahuri Mai ki Taiao (the night of turning towards the revealed world), and Te Pō Namunamu ki Taiao (the night of seeking the passage of the world) on the darker southern side. The framing that supports the panels and the bed, and the recesses within the concrete walls, are also detailed so they appear to 'weave' these two states together, and weave the bed and ceiling panels into the architecture. On the left hand side are a series of fold out shelving units that reference the Poutama Tukutuku pattern seen in many wharenui in New Zealand. The sections recessed into the right hand side concrete wall contain casement windows, as do the thinner and taller recesses in the left hand side wall.

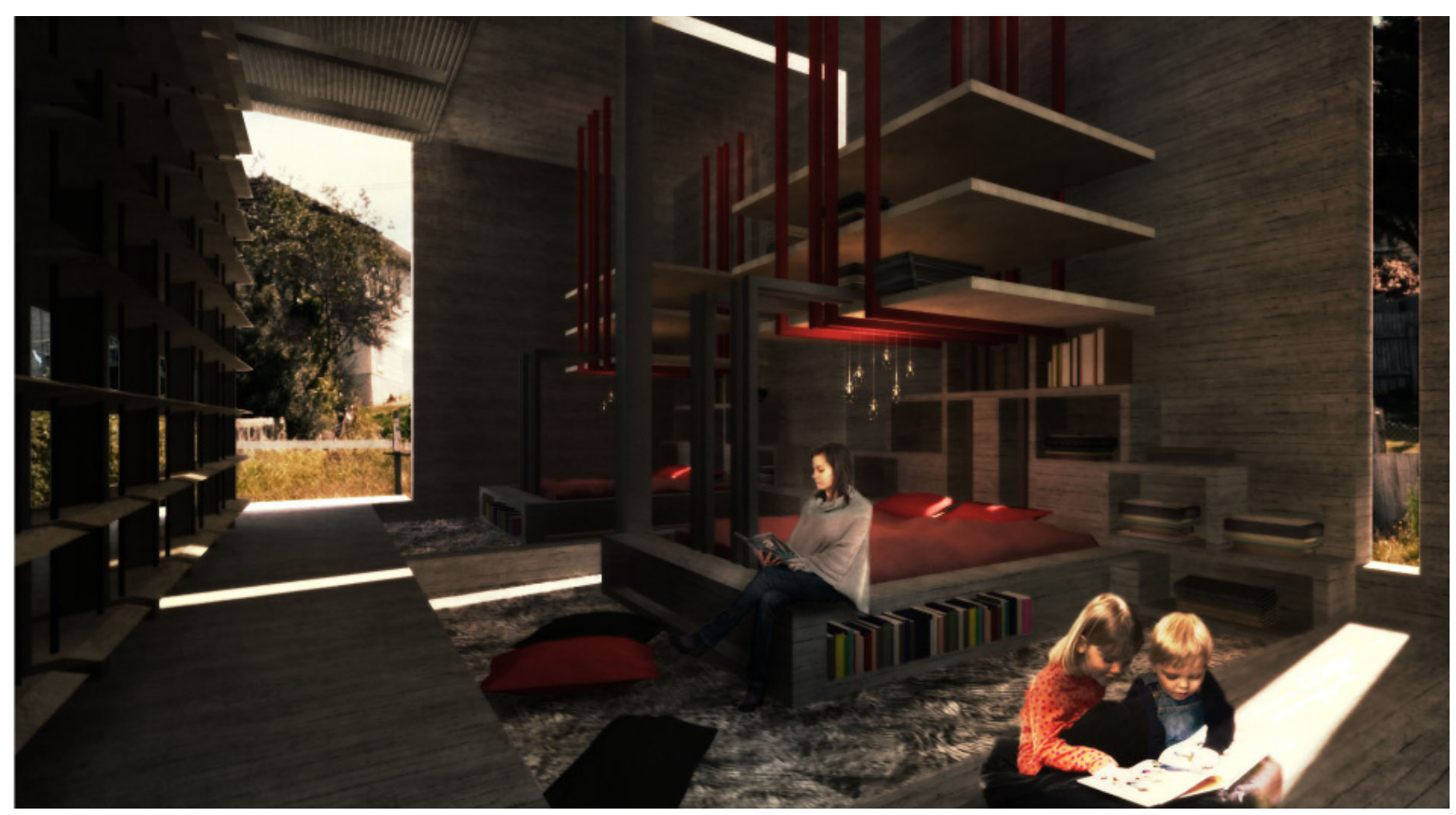

Figure 5.4 Interior Perspective of Children's Bedroom, Design One. As occurs within the parent's bedroom area, the children's beds are recessed into the floor, and framing appears to hang the bed from the ceiling in order to indicate the interaction between the states Te Ao Marama and Te Po that occurs between night and day. The recessed floor/bed platform is carpeted to provide greater comfort, and allow the edge of the recess to be used as a play area for children. The wall on the left hand of the image is constructed of a series of rotatable wooden blinds, and provides extra shelving space as well as a screening of the bedroom space from the bathroom and toilet area. 


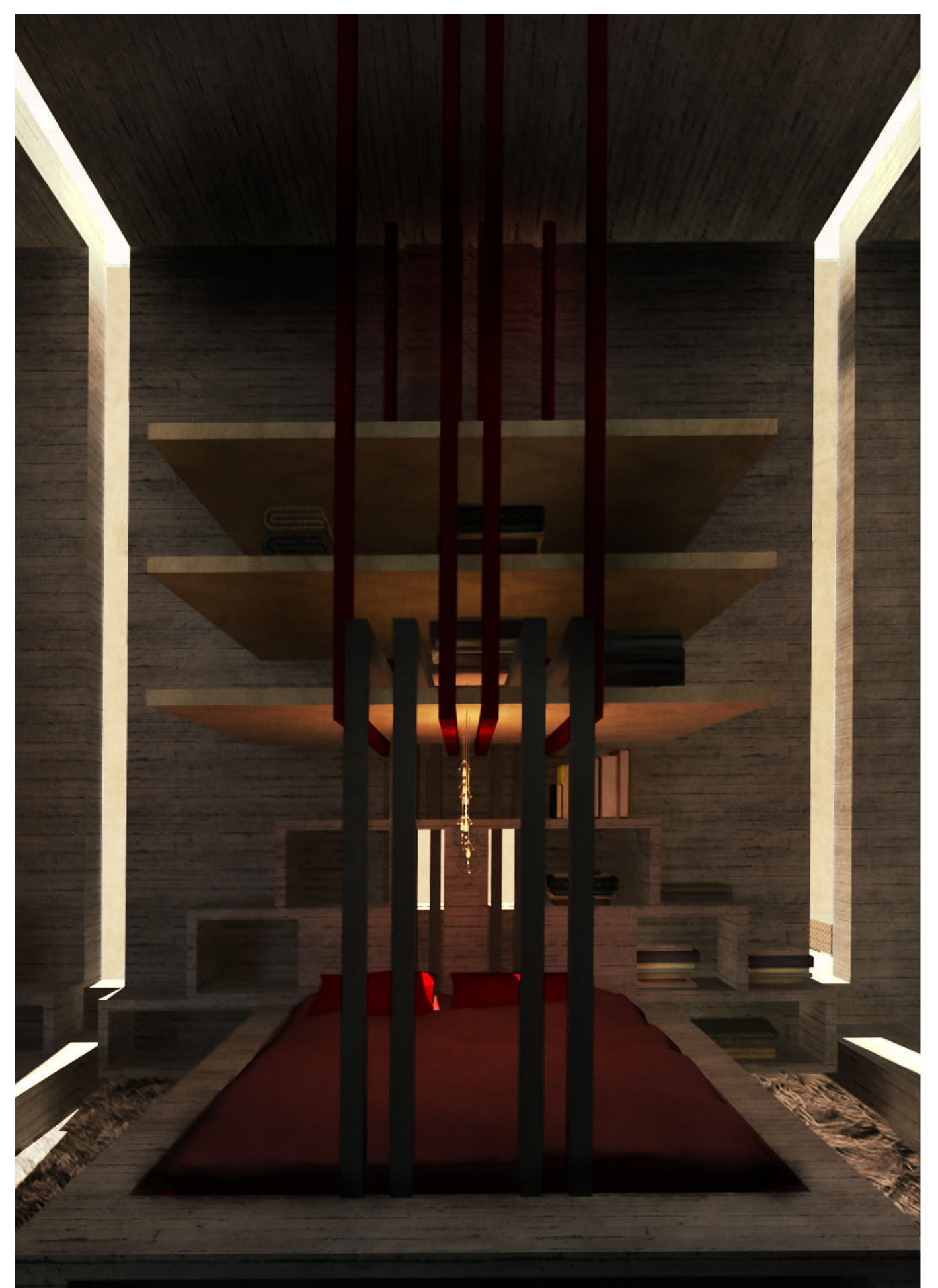

Figure 5.5 Interior Perspective of Children's Bed and Shelves, Design One. Extra shelving is also provided underneath and beside the bed to ensure there is enough storage space accessible to children. The shelving is integrated into the furniture, and the shelves at the head of the bed reference the Poutama Tukutuku pattern which represents Tane's journey to attain the three baskets of knowledge. 


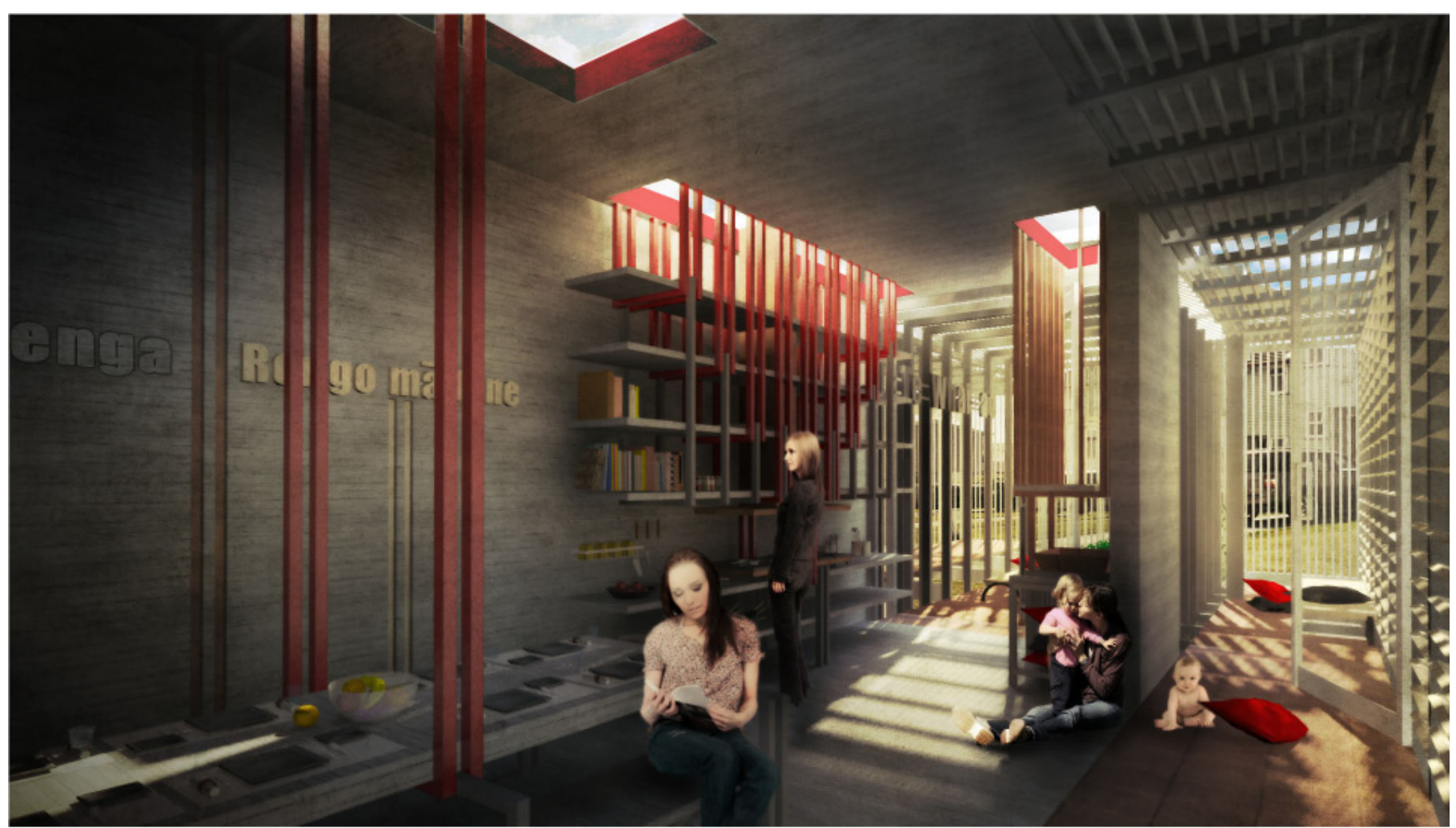

Figure 5.6 Interior Perspective of Kitchen and Dining Area, Design One. This area conveys the transition between Te Ao marama and Te Po, both vertically and horizontally. Like within the bedrooms, the built in furniture is woven into the fabric of the building through a series of light steel frames in a manner the communicates the tension between light and dark, openness and enclosure. The writing and recesses within the left hand side wall, and the framing supporting the dining table also convey the confirmation of the tapu of Tumatauenga over the tapu of Rongomatane that occurs at the point where cooked food is consumed. The extended section of the room of the right hand side provided extra space for children to play. The right hand side wall is constructed out of Louverline horizontal weatherboard panels which can open to allow extra light and air into the space, and close when a water-proof wall is required.

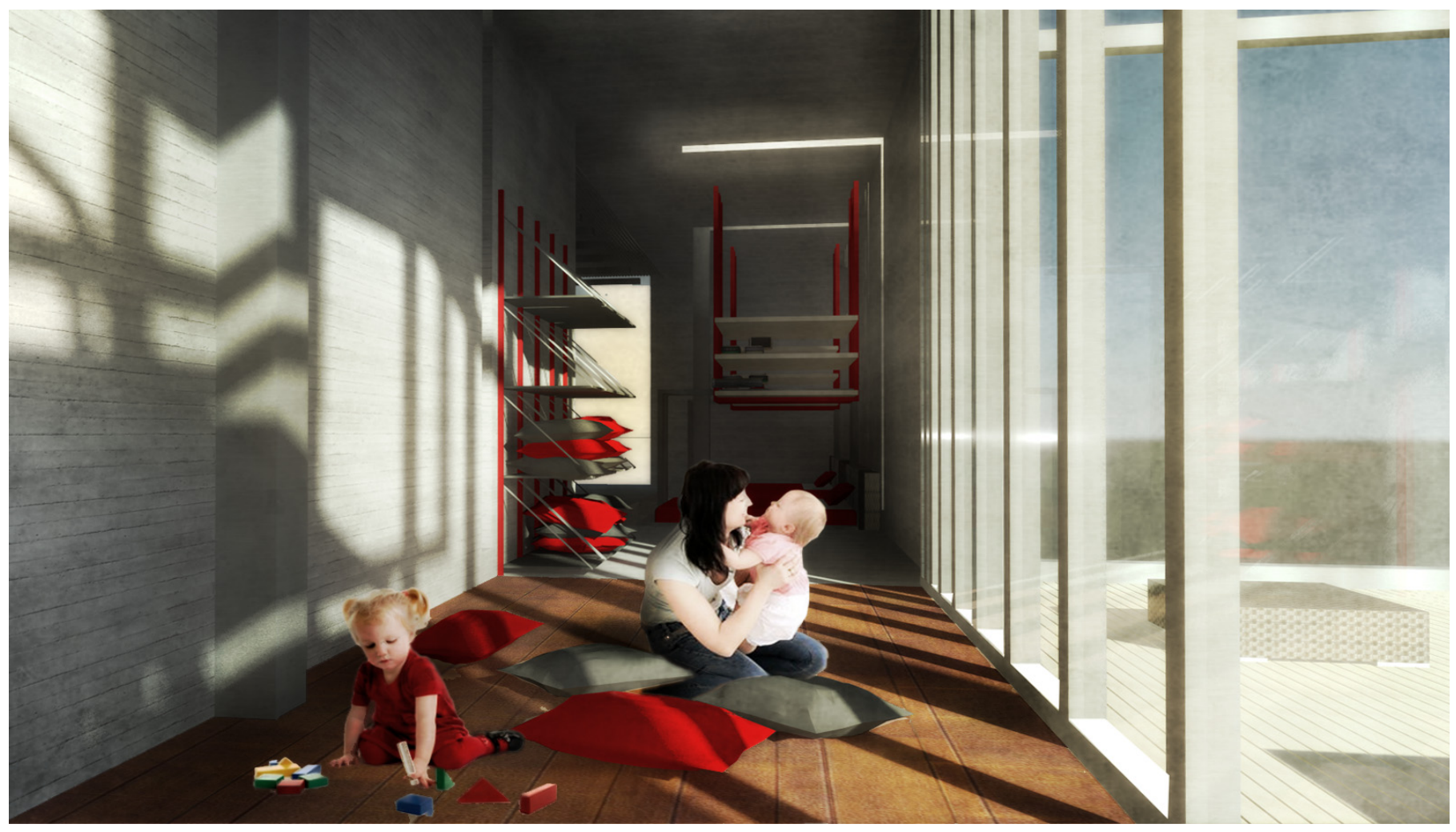

Figure 5.7 Interior Perspective of Lounge/Play Area, Design One. This space, while still fully able to be enclosed from the exterior environment, shifts the quality of the space through material changes and light levels. It is intended that this space be a flexible living and play area for the family connected to the bedroom areas and also the more communal outdoor living areas. Although still simple in its constructional detailing, it begins to break the coherence of the concrete forms of the bedroom spaces through the linear lines of the metal tile flooring and steel mullions supporting the right hand side glazed wall. The shelving depicted in the rear of the image is used to store a series of bean bags, cushions, and blankets which can be used within the space to create greater comfort and a greater flexibility of use within the space. The two middle sections of the right hand side glazing are able to be opened as casement doors out onto the outdoor deck area. 


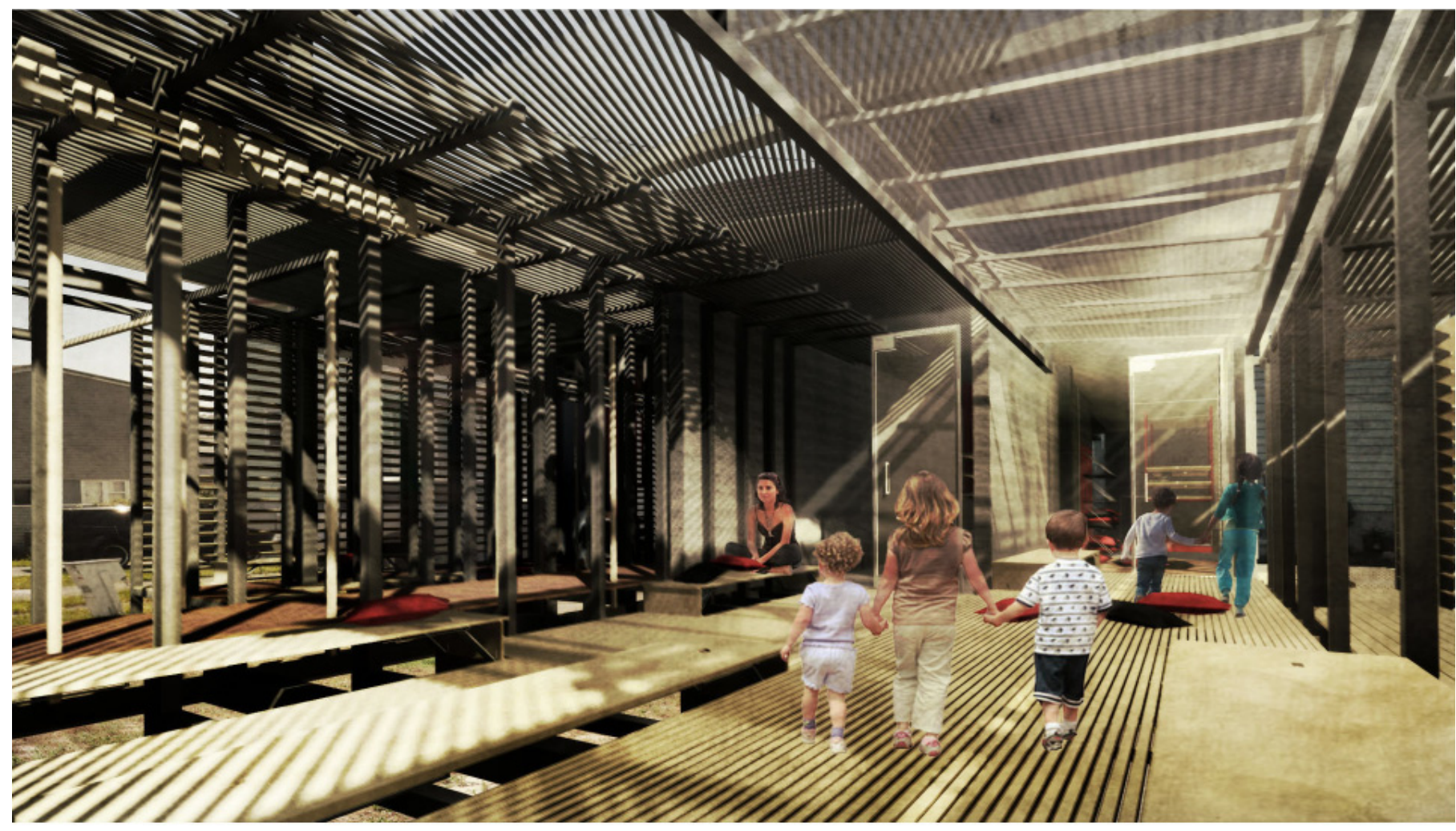

Figure 5.8 Exterior Perspective of Outdoor Living Area, Design One. This area is outdoor, but sheltered from the sun and rain is provided by a light opaque rain screen and various screens of steel tensile cable strung between the concrete elements and steel framing structures of the house. There are a series of pop-up wooden panel benches that can be raised to provide seating or lowered to provide a more open singular level deck. The central raised section on the left screens, but does not separate, this area from the vegetable garden and outdoor umu cooking area on the rear left hand side of the image.

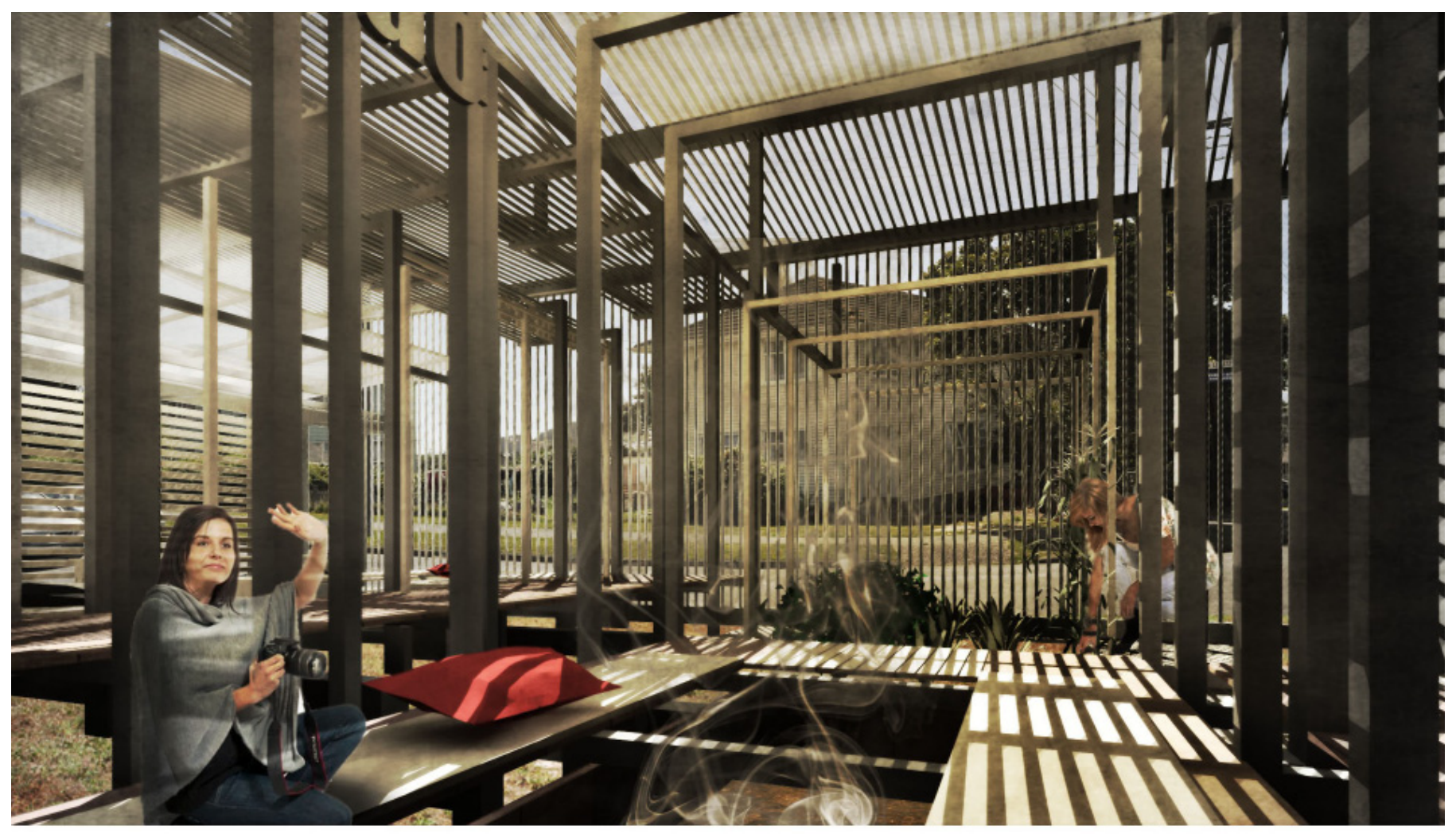

Figure 5.9 Exterior Perspective of Outdoor Umu Cooking Area, Design One. This perspective is taken from the other side of the outdoor area, immediately outside the kitchen. Two wooden panels are able to be lifted out of the deck to reveal an umu within the ground. The slim timber framing conveys the area of the recessed vegetable garden behind the umu area. 


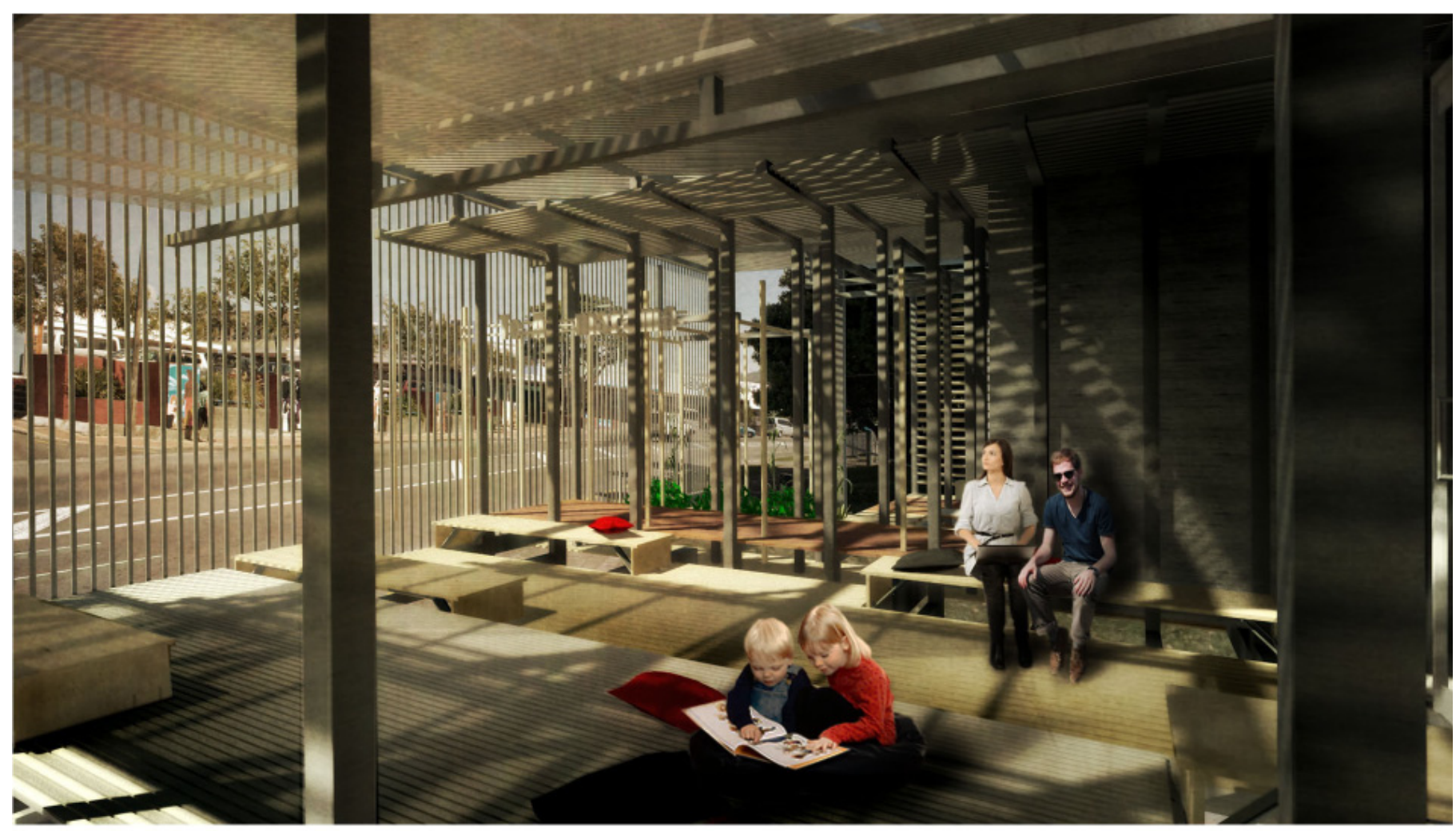

Figure 5.10 Exterior Perspective of Outdoor Living and Cooking Area, Design One. This perspective conveys the comparative lightness and openness of the outdoor areas to the enclosed bedrooms, but also the greater conflict and netting effect generated by the build-up of and contrast between the thinner steel and wood columns, beams, and cables.

Additionally, the house reads on one side as a threshold of interaction between food and people, and on the other side between individual people and collective groups of people (Fig.5.11-5.12). The interaction between food and people is expressed through a series of functions through the house that represent the growth, cooking, consumption, and removal of food within the house. Similarly the interaction between individuals and groups of people is conveyed through the interaction between spaces of individual occupation (bedrooms), close collective groups (living room), and wider social groups (larger entertaining space and neighbouring properties).

Openness/enclosure, public/private and light/dark all connote clear spatial qualities easily associated with architecture. However, the threshold between conflict/resolution is more conceptual, and for this reason, a material palette of concrete-steel-wood, was used to associate resolution/calm-interaction-conflict/chaos with a spatial quality. The association extended beyond simply the use of the material in different sections of the house, to the way the material is used and the constructional relationships conveyed in order to express the qualities of conflict and resolution.

The primary structure of the house is a series of steel frames and supporting tensile ties, from which the majority of the house hangs (Fig.5.13). The primary structure acknowledges the process of the first stage of the initial experiment, which constructed a collective depiction from various images of wharenui. Many of the individual images had black frame-like edges around them, and therefore the final depiction appears to have a series of frames that house the depiction within them. While it was accepted that these frames were a by-product of the photographic process, rather than a physical part of the wharenui, they were integrated into the design to reflect the collective process of layering individual images over one another in order to create a new space. In a similar manner to the original depictions of the wharenui generated in Chapter four, and to the images exploring the recurring identities and narratives within state house developments generated in Chapter three, the structure supports the architecture, utilising a series of frames in order to legitimise and support the new architecture.

The choice to elevate and hang the majority of the house above the ground plane was a way to emphasize the functions within the house that did interact with the ground, and those that take place above it. This distinction was important to establish, in particular on the western side of the house, where the interaction between food, and therefore the land, and people was the primary relationship of tapu explored. The vertical floor levels throughout this side of the house were used to convey the journey of food through the house (Fig.5.14). 


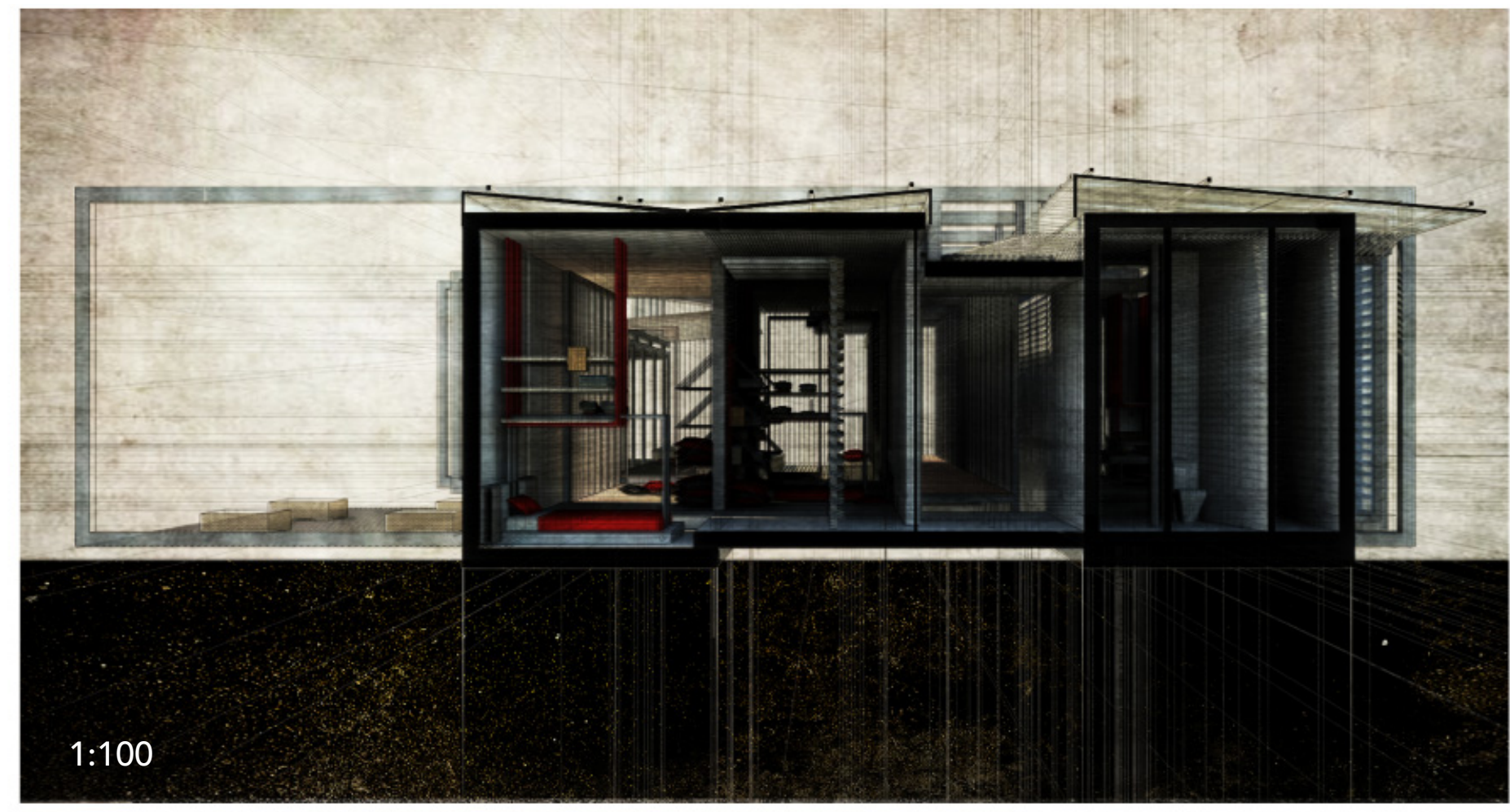

Figure 5.11 Latitudinal Section A-A', Design One. This section taken across the bedrooms and recessed bathroom area conveys the splitting of the house between the interaction between individuals and groups of people on the one side, and the interaction between people and food on the other. Additionally it shows the points at which contact is made by the concrete elements to the ground plane within the toilet and bedrooms, to communicate the connection that is made between people and the land at these points. The section also conveys the comparatively enclosed, dark, and resolved nature of the spaces at the southern end of the house. 
Joshua Blandford. Possibilities Towards a Post-Colonial Architecture in Residential New Zealand

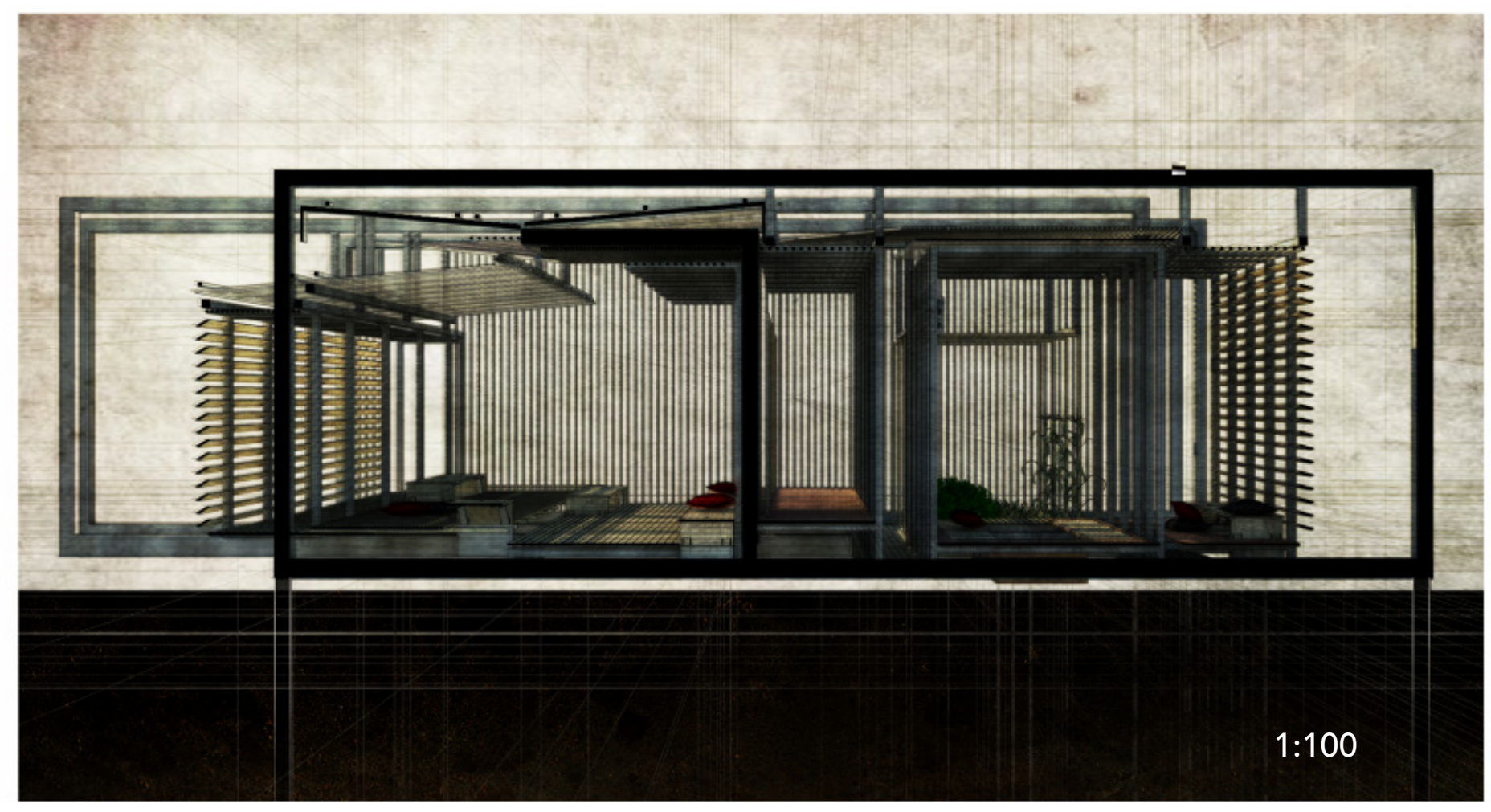

Figure 5.12 Latitudinal Section B-B', Design One. This section, taken through the outdoor area, again conveys the split between the communal social living area on the left and the food growing and cooking outdoor areas on the right. It also conveys the containment of the building within the series of structural steel frames that support the building. 


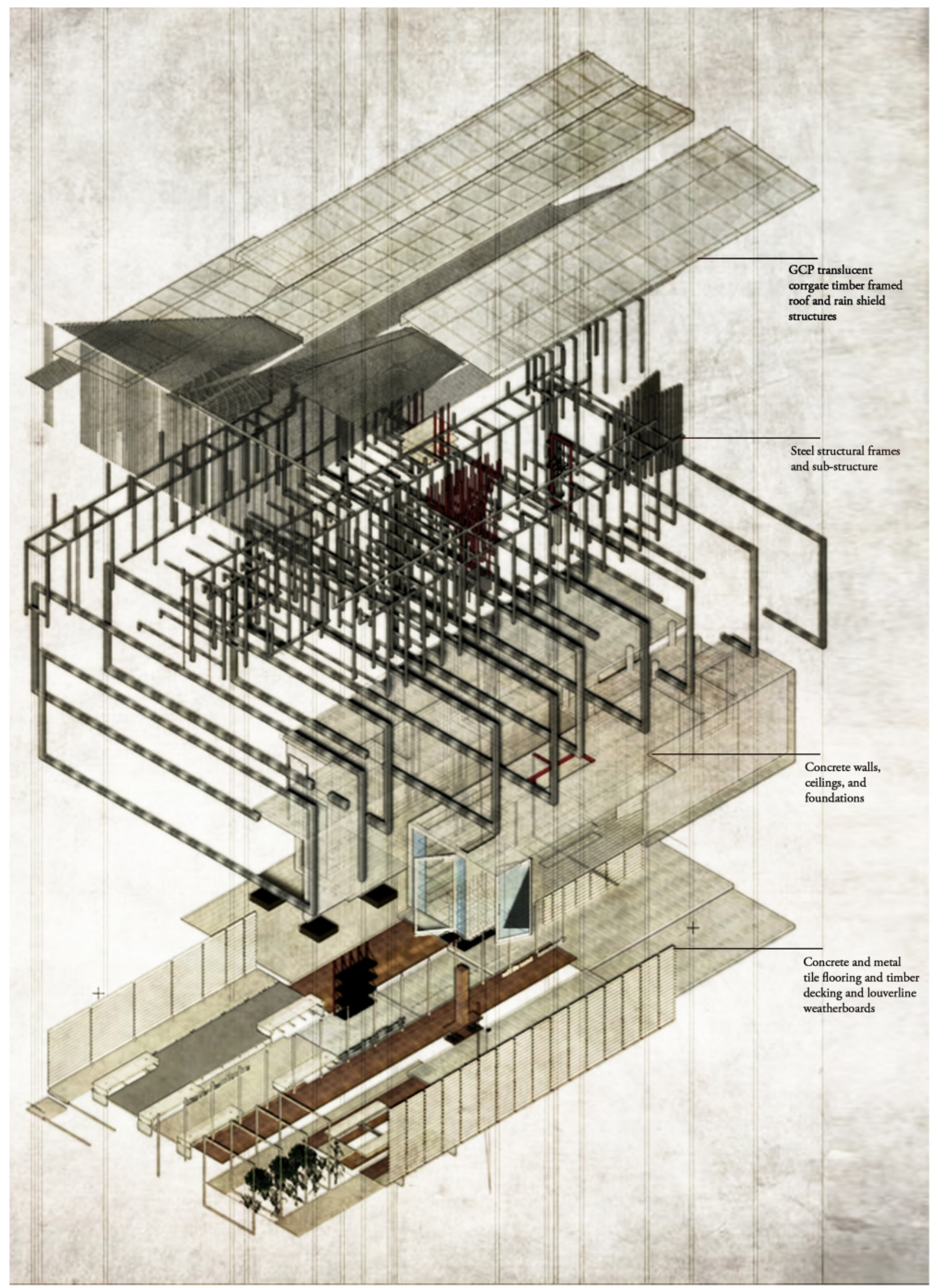

Figure 5.13 Exploded Isometric, Design One. This drawing conveys the various structural and architectural elements within the building. At the middle of the drawing lie the structural steel frames that enclose the entire building. Above these are the series of sub-structural steel and timber frames that support the flooring and roof structure. Below are the concrete elements and the metal tile and timber sections of flooring. 


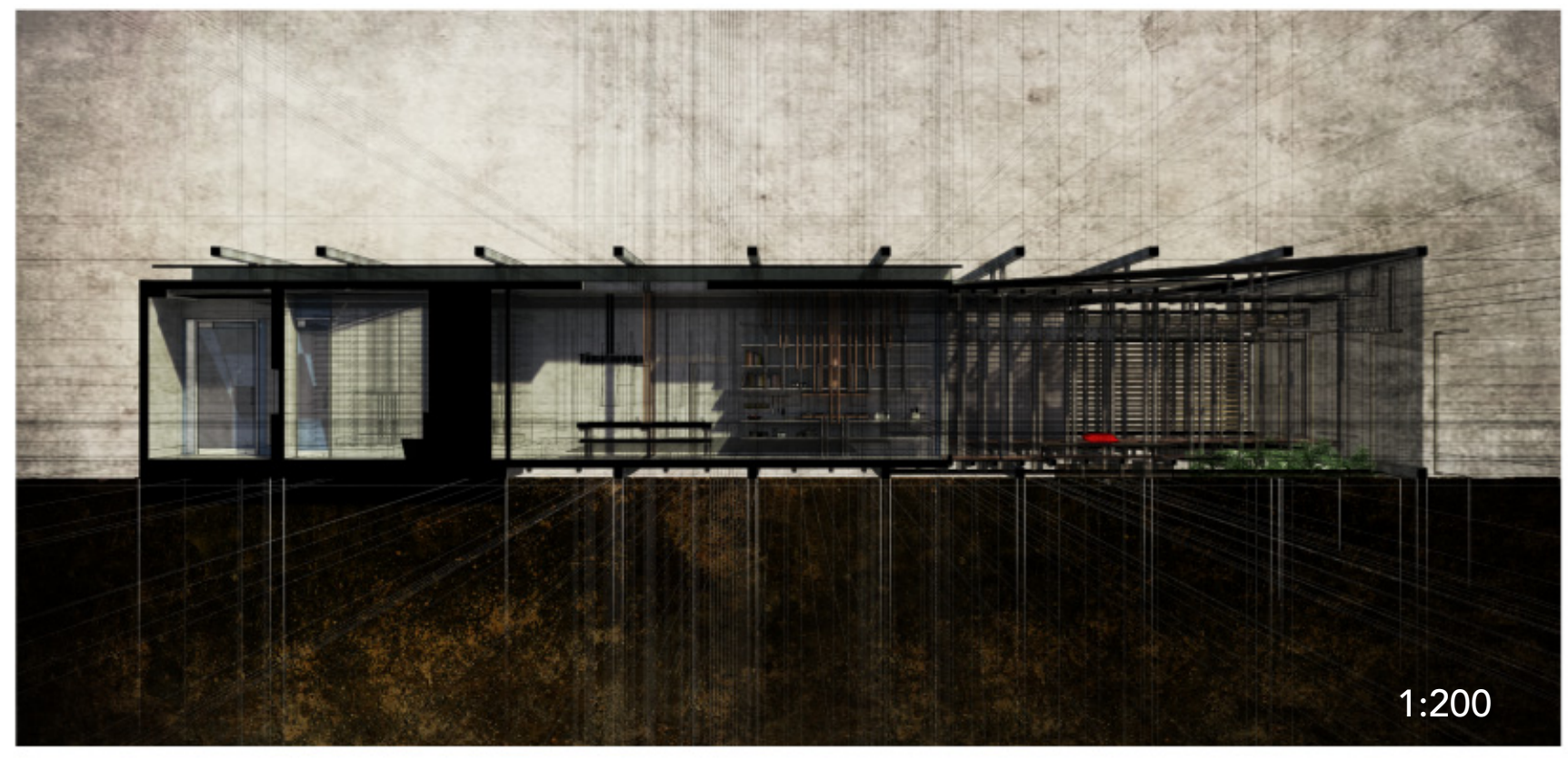

Figure 5.14 Longitudinal Section C-C', Design One. This section conveys the transition in spatial qualities that occurs within the building. In particular it shows the transition from the simpler and more resolved formal treatment at the south-western end of the building to the more conflicting formal effects generated through the overlapping of thinner steel and wood columns, beams, and cables at the north-eastern end of the building. 
For example, the connection between people and the ground that is forced by the removal of food from the ground, and the return of food waste to it, is emphasised through physically connecting the vegetable garden at the front of the house and the ablution blocks at the rear of the house to the ground plane. These connections stand in contrast to the spaces within the middle section of the house which are hung above the ground plane to communicate the raising of food out of the ground in order for it to be consumed by people, confirming their position as living beings within Te Aō Marama. The ground level is used, in this way, as a metaphorical element which expresses the process of removing food from the ground, people consuming food above it, and the returning of food waste to the ground.

The design integrates the requirements and criteria established through the empirical research in Chapter five. The steel tensile cables that run over the top of the outdoor spaces were run from the top of the final structural frame to the ground in order to establish a greater physical barrier between the house and the street (Fig.5.15). The house also has moveable in-built furniture within the outdoor spaces to accommodate a range of social activities (Fig.5.16), and references the Māori narratives used within the design by naming spaces according to their position on the journey between Te Aō Marama and Te Po (Fig.5.17-5.18).

Developing the conceptual outcome generated in Chapter four, by reading it in terms of the cultural narratives embedded within the wharenui, created an architectural outcome that critiqued the conception of threshold mediated by architectural mechanisms of representation and the State House. The design critiques the conventional notions of threshold expected within residential architecture. The architecture of the State House strictly enforced divisions through physical elements and a spatial order arranged around a central corridor, elements that are still common in residential New Zealand homes. This design however initiates threshold through changes in spatial quality rather than physical elements. It also critiques the conventional spatial practices associated with residential architecture by linking functions together in a manner that reflects the interaction or processes of living between individual people and groups of people, and between people and food, that commonly occur within a residential house.

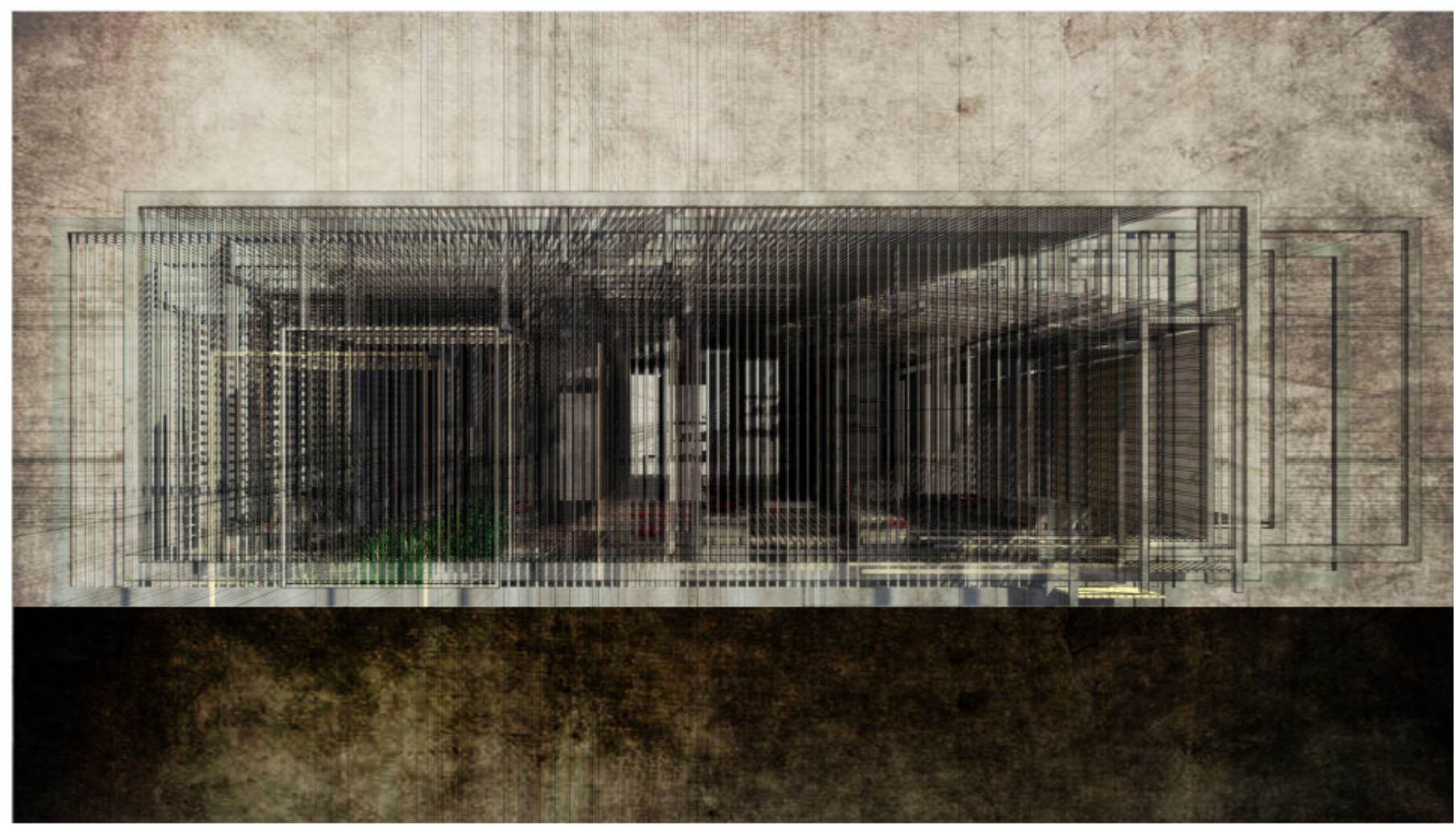

Figure 5.15 Front Street Elevation, Design One. This image conveys how the steel tensile cables were wrapped around the street facing steel frame in order to create an emphasised barrier between the outdoor areas of the house and the street in order to align with the current spatial practices in Eastern Porirua. 

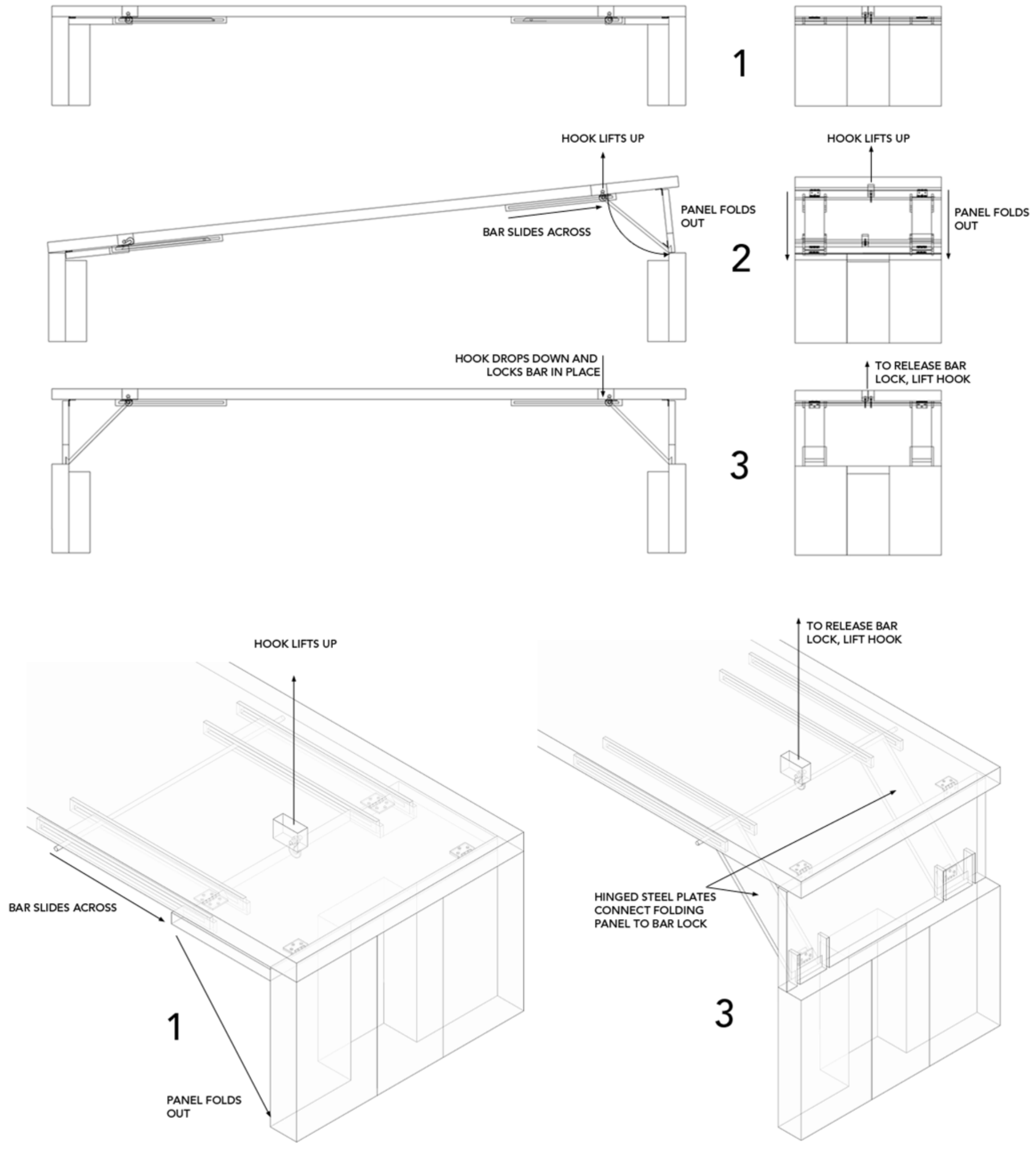

Figures 5.16 Isometrics and Elevations Detailing Operation of In-built Furniture, Design One.This drawings details the operation of the pop-up bench furniture located throughout the exterior living spaces. The benches are designed so they are able to put up one end at a time, and therefore able to be put up by a single person. These seats allow the outdoor spaces to fulfil a greater range of requirements as they can shift the dimensions of the various alcoves within the space to be more intimate or communal as required. 


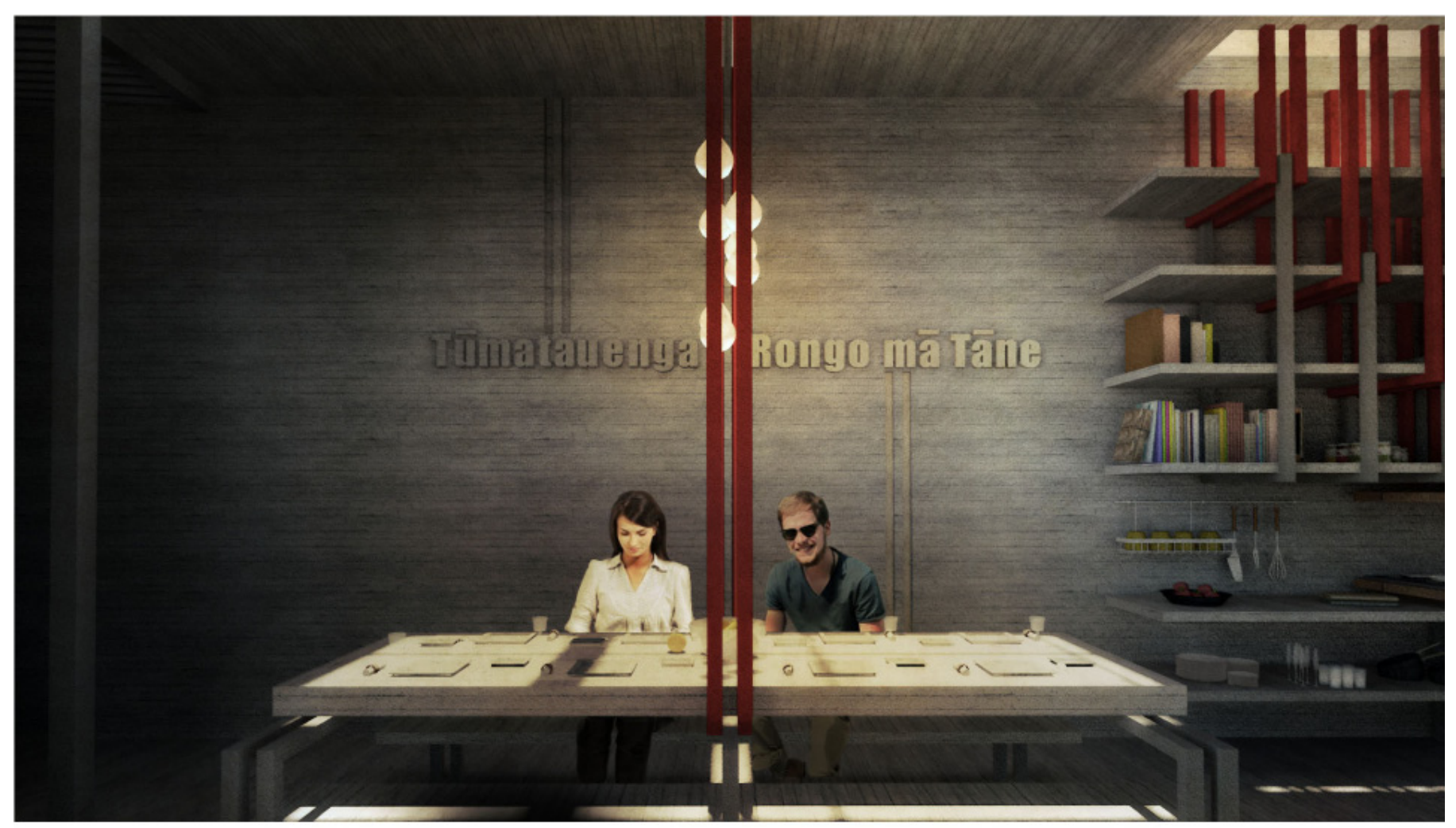

Figure 5.17 Interior Perspective of Te Reo Writing and Dining Area, Design One. This image conveys the detailing of the dining room table framing and the wall screeding and writing to communicate the interaction between Tumatauenga and Rongomatane on this side of the house, and the confirmation of the intrinsic tapu of Tumatauenga over the intrinsic tapu of Rongomatane when cooked food is consumed.

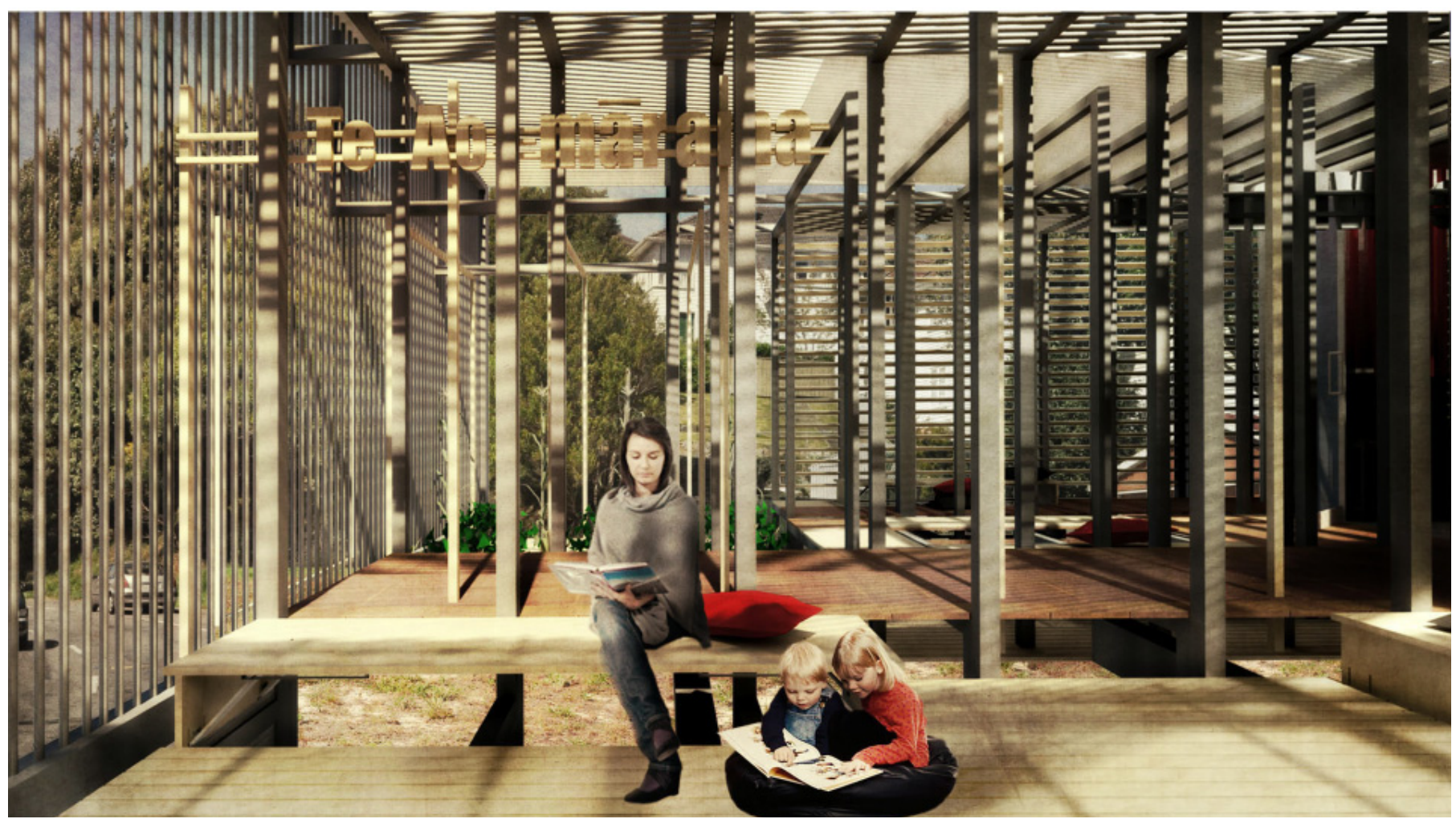

Figure 5.18 Exterior Perspective of Te Reo Writing and Outdoor Sitting Area, Design One. This image displays the naming of the outdoor area as the realm of Te Ao Marama, and the extension of this world out beyond the property fence. 


\section{Design Two}

The second design developed the conceptual design generated in experiment two, Chapter four, by reapplying Shirres' conceptual understanding of tapu and noa in order to produce a second site-specific design (Fig.5.19-5.21). Areas defined by the original drawing as points of noa were treated as points of architectural resolution. As the conflicts and interactions between tapu are cleansed, or one tapu confirmed over another at the points of noa, the architecture immediately surrounding them is more resolved and clarified in terms of function and ease of occupation, and has more minimal structural and constructional relationships. These areas are expressed through solid blocks of in-situ concrete in order to convey their stability and calmness due to the resolution of conflicts in tapu within them (Fig.5.22-5.23). The conceptual understanding of these elements as stable and calm resulted in them becoming the foundations and primary structure for the house (Fig.5.24). 

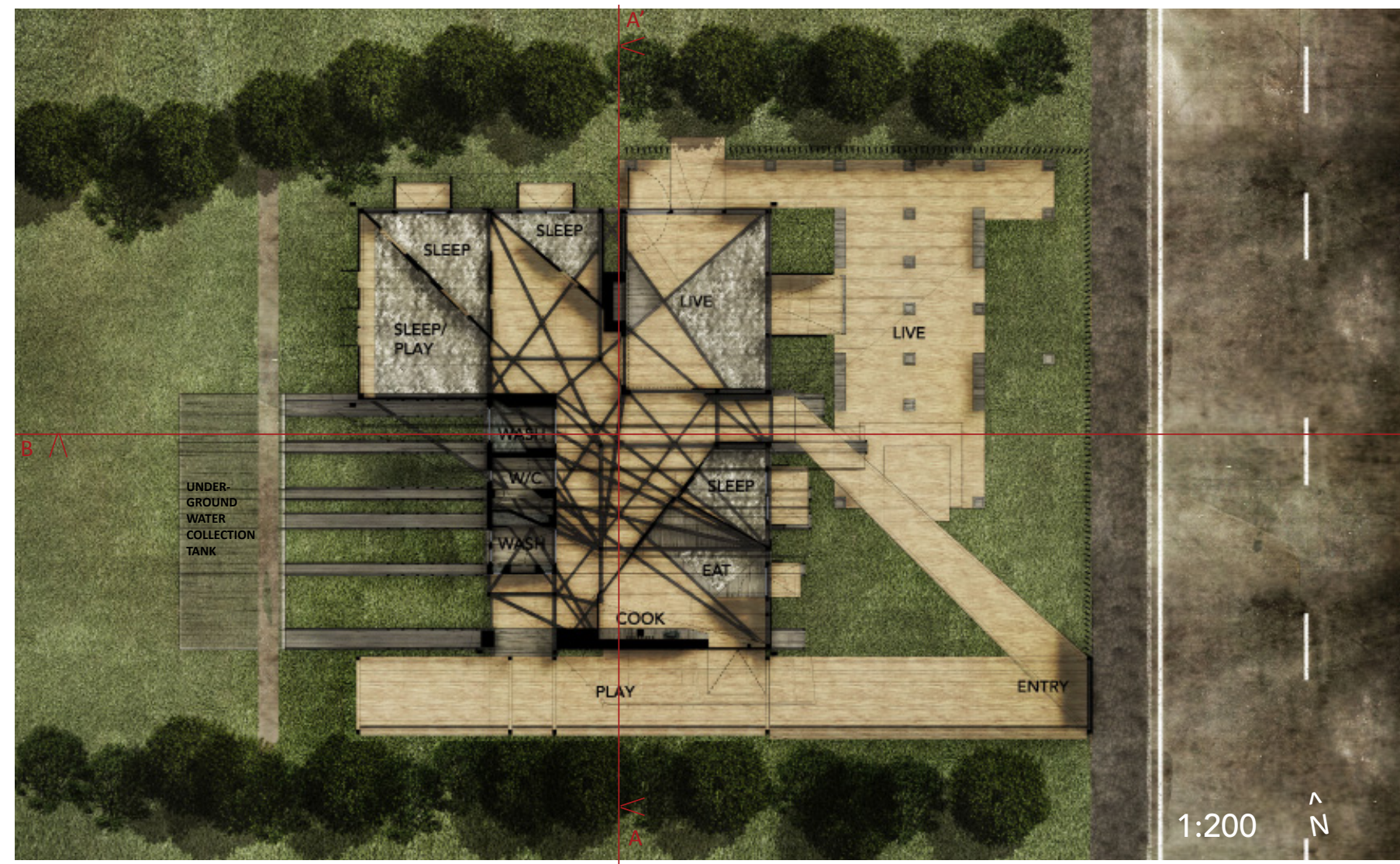

Figure 5.19 Plan, Design Two. Clearly depicted within the plan are the heavier concrete noa elements of the building, and the interruption of easily dimensioned and ocuppiable space caused by the conflicts between tapu within the centre of the house. 


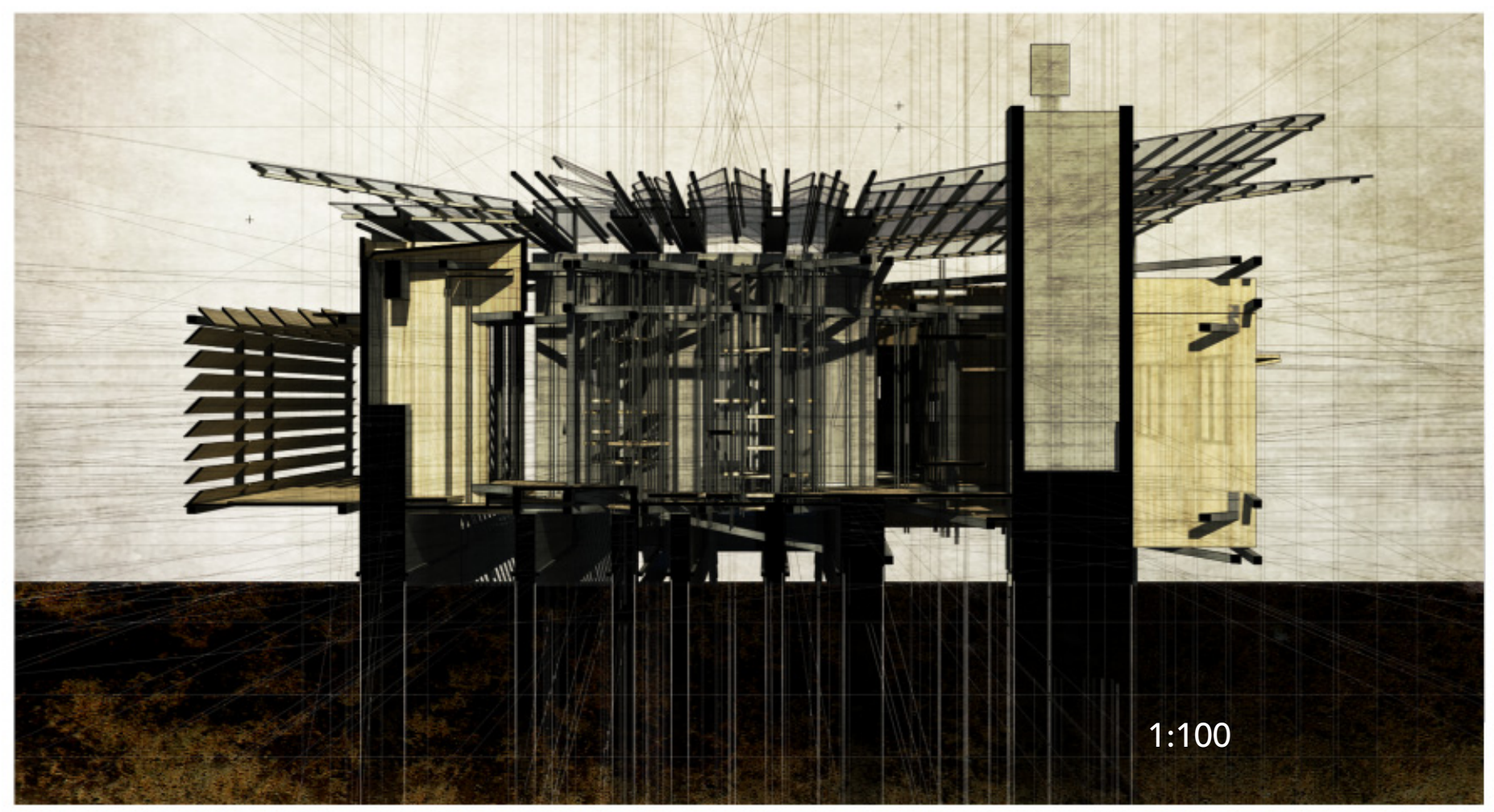

Figure 5.20 Latitudinal Section A-A', Design Two. This section shows the relative floor levels of the spaces within the house, and the relationship between the concrete foundations, steel substructure, wooden wall and floor panels, and rain shield. 


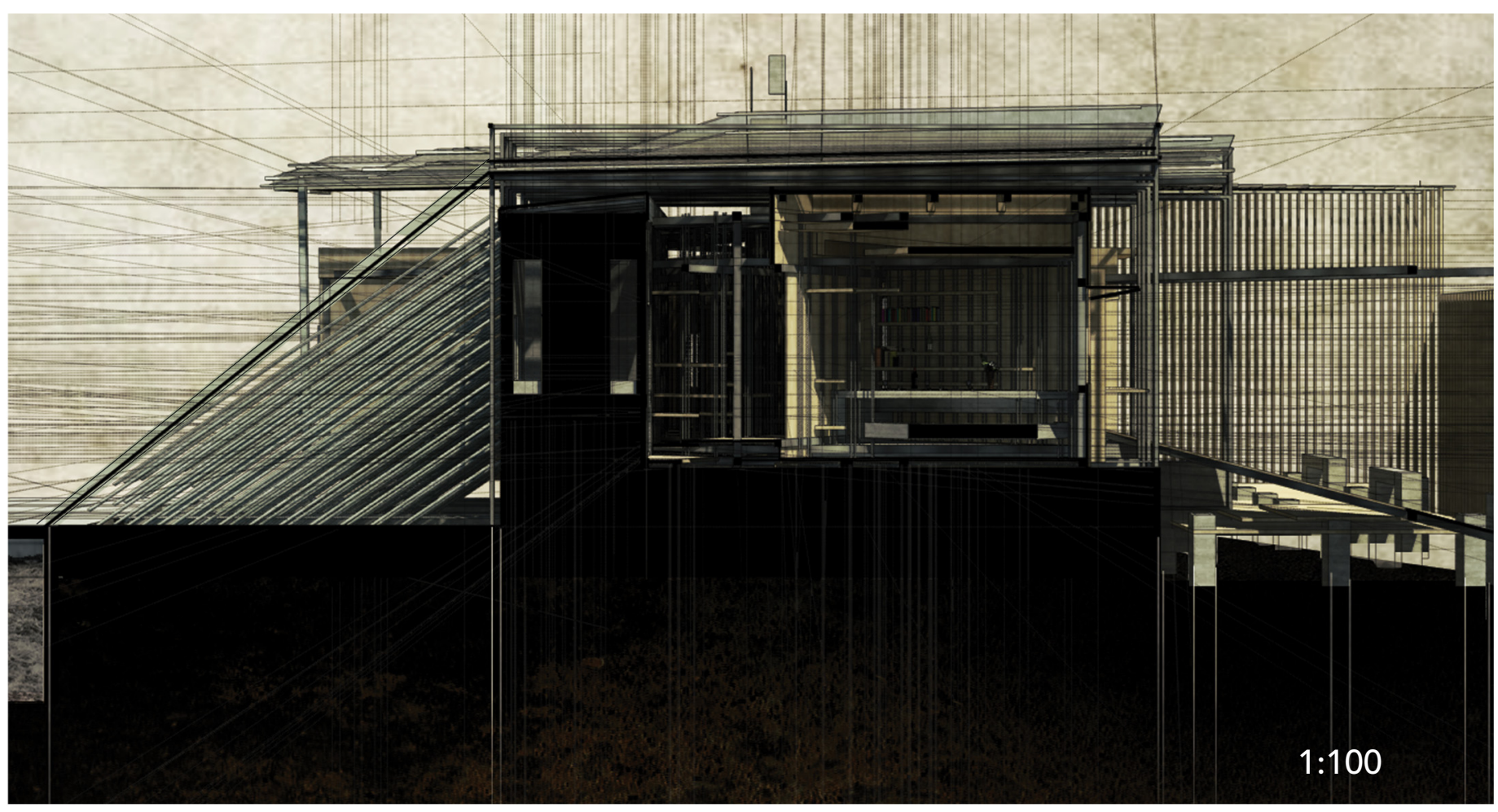

Figure 5.21 Longitudinal Section B-B', Design Two. This section conveys the cantilevering of the bedroom spaces off the concrete foundations connected to the concrete noa elements of the house, and the recession of the bedroom floors so that the top level of the mattress aligns with the floor level outside the bedrooms. 


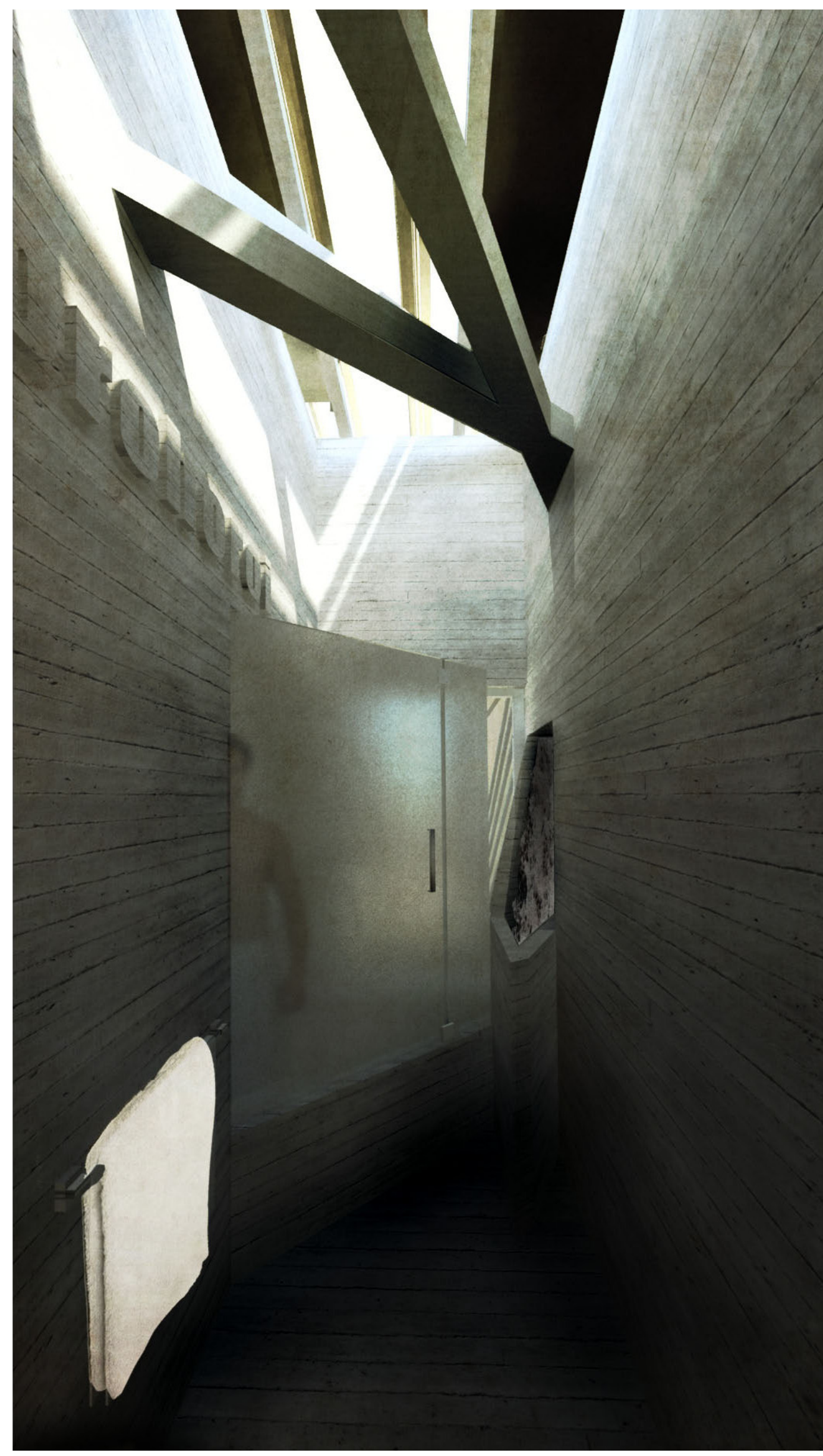

Figure 5.22 Interior Perspective of Shower Room, Design Two. This perspective shows the resolved and solemn quality of the spaces of noa within the house. The basin on the right and shower at the centre are recessed into the concrete walls, and the water of the basin runs from the top of the recess and over the concrete walls, and directly out of the top of the recessed part of the shower. The coherence of the form is slightly broken by the intersecting steel substructure frames that punch through the space at the top of the image, conveying the loss of a state of noa as the distance from the ground foundations and areas where water flows increases. 


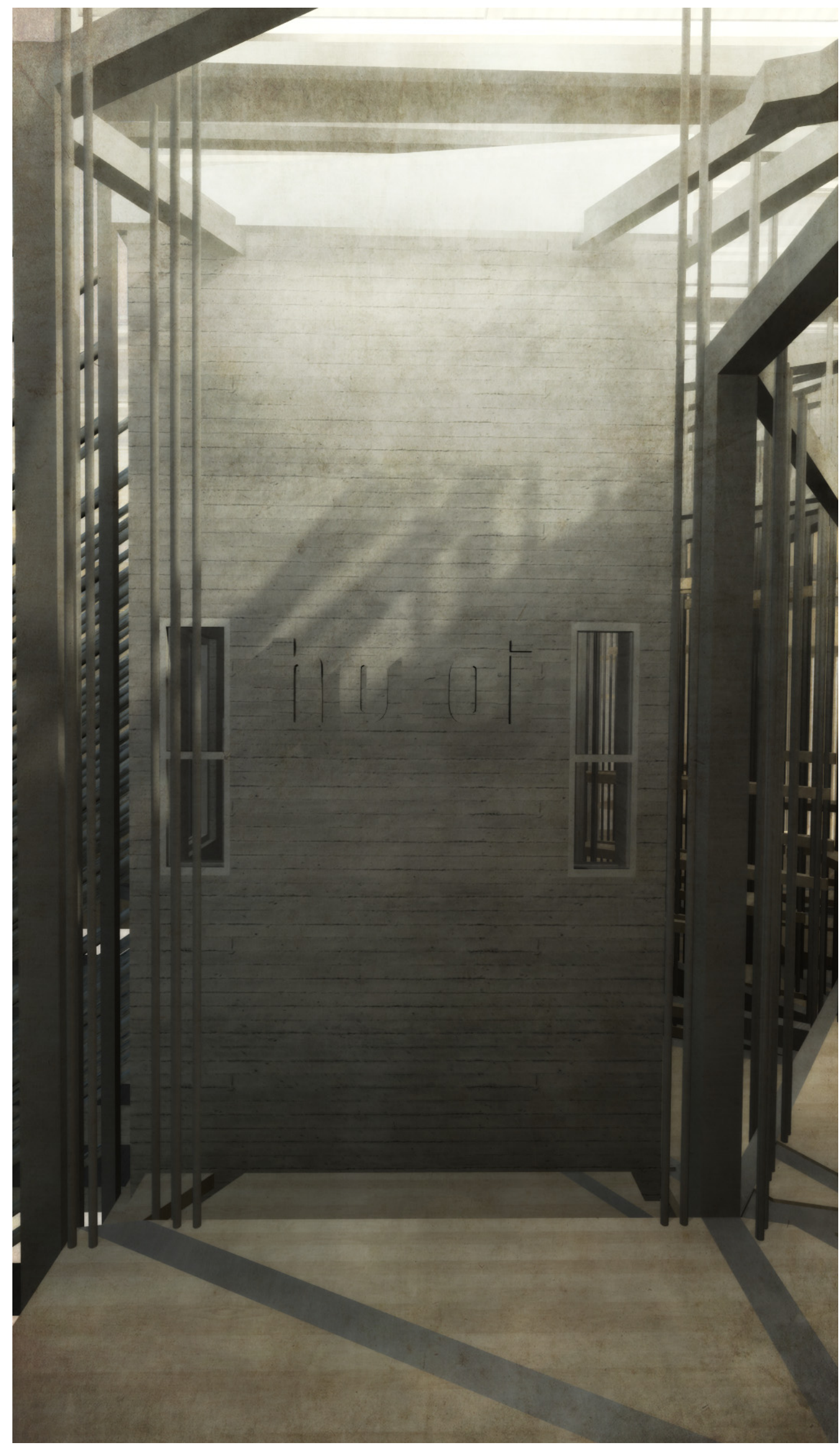

Figure $\quad 5.23 \quad$ Exterior Perspective of Rear Entrance, Design Two. The two vertical sliding windows within the concrete wall open into the hand basins of the wash room, providing the ability for occupants to horoi (wash) themselves with water in order to cleanse any tapu they carry with them upon entering and existing the house. 


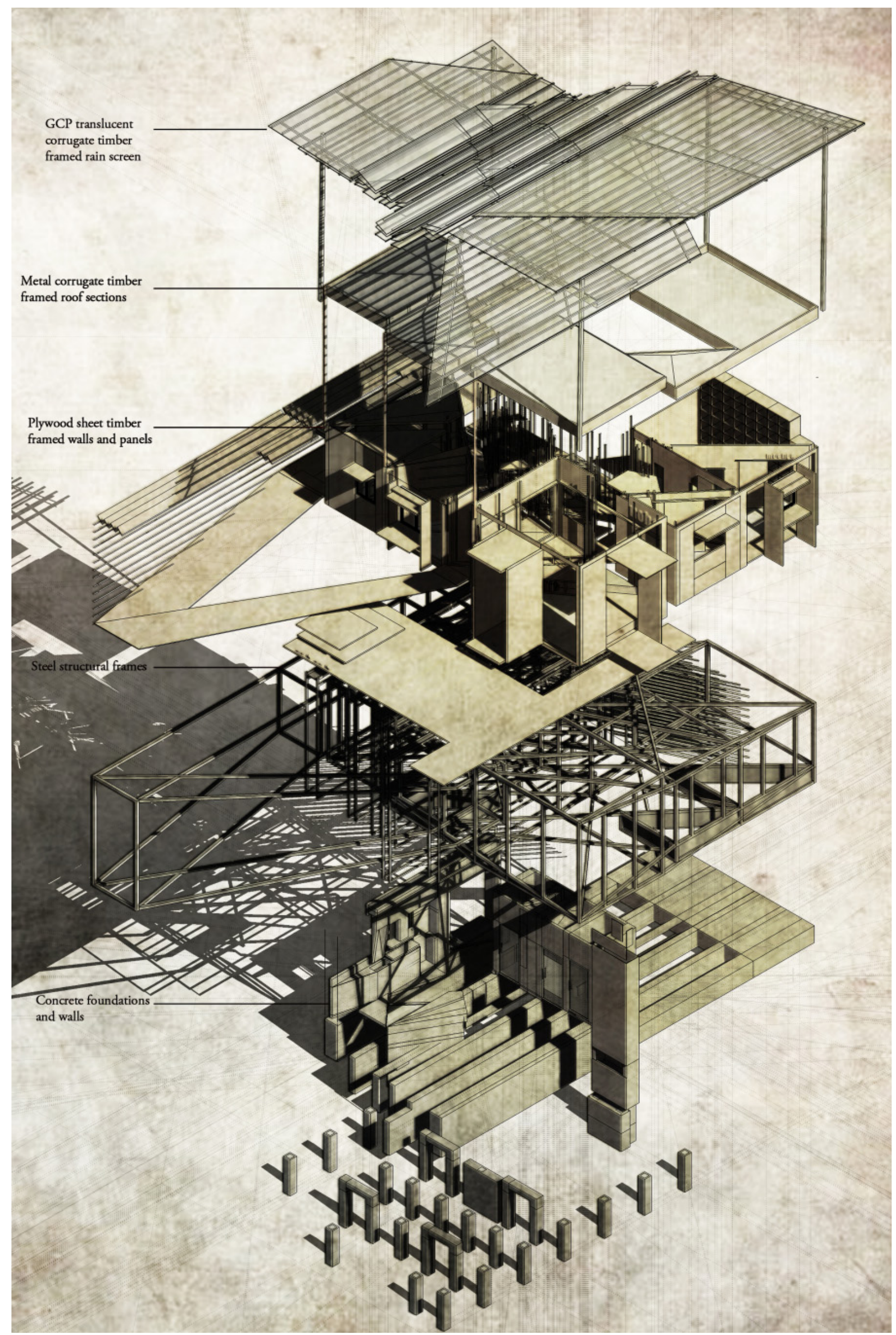

Figure 5.24 Exploded Isometric, Design Two. This exploded isometric shows the relationship between the concrete foundations and spaces within the house to the steel substructure, wood panelling, and rain-shield structure. 
The mechanisms by which conflicts in tapu are cleansed or resolved are conveyed at these points. For example, where water is the mechanism which acts to cleanse conflicts in tapu in order to create a state of noa, the architecture frames the movement of water, conveying its presence to inhabitants (Fig.5.25). Likewise, where the consumption of cooked food is the mechanism, the points where food is cooked and consumed are emphasised within the architecture, and convey the confirmation of the inhabitants as living within Te Aō Marama through separation with the ground (Fig.5.26).

There is one exception to the rendering of areas of noa as in-situ concrete. This is in the water collecting rain shield that 'floats' above the house (Fig.5.27). There are two reasons for this decision. First, the interaction of conflicting tapu between the plane of the roof and the ground plane was read as a disruption to, or erosion of, the state of noa between the two planes. Second, the roof structure is the only point where new paths, or areas, of noa are established within the house. All of the other areas of noa (expressed in concrete) affirm relationships that were already established within the State House, for example, where water ran through the bathroom sink, toilet, or bathtub. These relationships have been operating on site for many years and were consequently given a strong architectural presence in the final design. However, the guttering paths are new, and were established through reading the roof as an extension of the points of noa within the planar drawing generated in the initial experiment. Consequently, the roof is constructed of translucent polyester GCP corrugate roof sheets and lightweight timber framing, that while connected to the in-situ concrete elements through steel frames, highlights the instability caused by the interaction of tapu between the noa foundational areas and the roof plane. The roof highlights the lighter, fresher, and less stable state of noa than is present within the heavier concrete elements, and maintains a visual connection the water as it flows over the roof structure. 


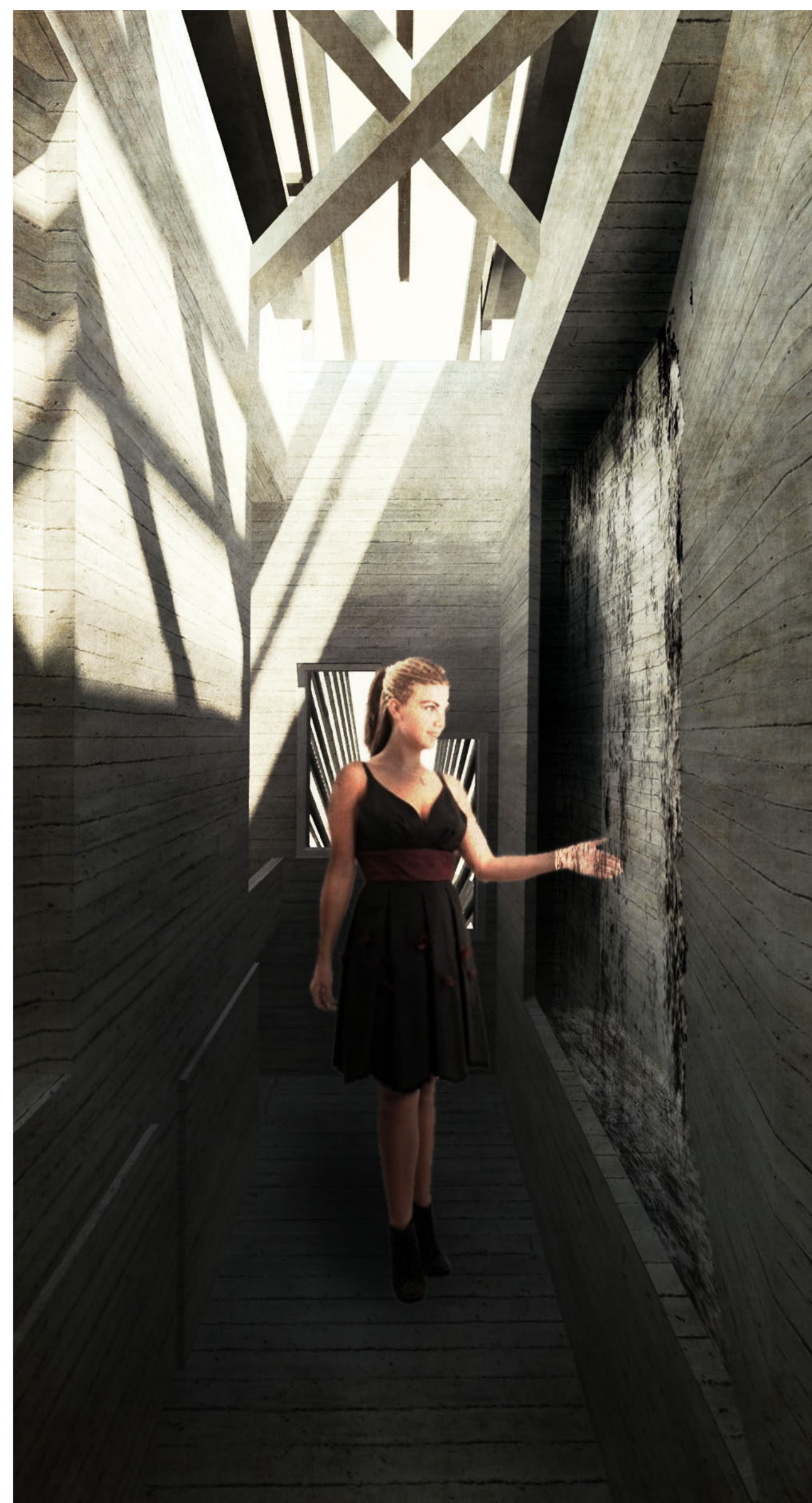

Figure $\quad 5.25 \quad$ Interior Perspective of Washroom, Design Two. The hand basins are recessed into the left hand wall and the bath into the right hand wall. The water runs from the top rear of the recesses down the concrete wall as shown in the image. 


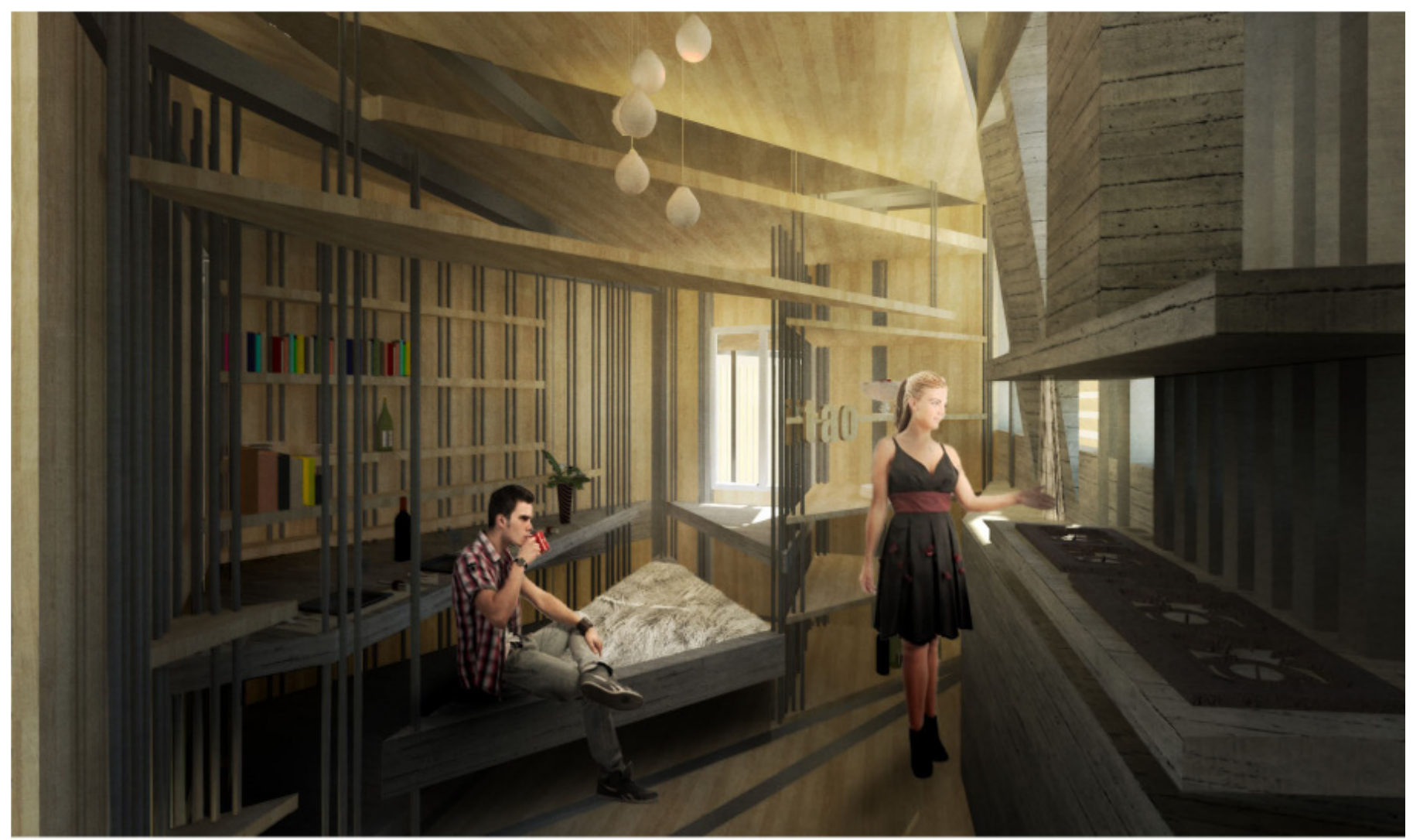

Figure 5.26 Interior Perspective of Cooking and Dining Area, Design Two. The stove is cantilevered and hung from the concrete wall on the right, and the water for the sink immediately to the left of the stove runs down a concrete funnel into the sink as shown in the image. The dining table on the left hand side of the image is hung from a series of steel cables connected to the steel substructure, and the dining table seating is an extension of the concrete foundations, conveying the confirmation of the tapu of Tumatauenga over Rongomatane that occurs at the point where food is consumed. The panels at the rear and side of the room form a series of moveable shelving units.

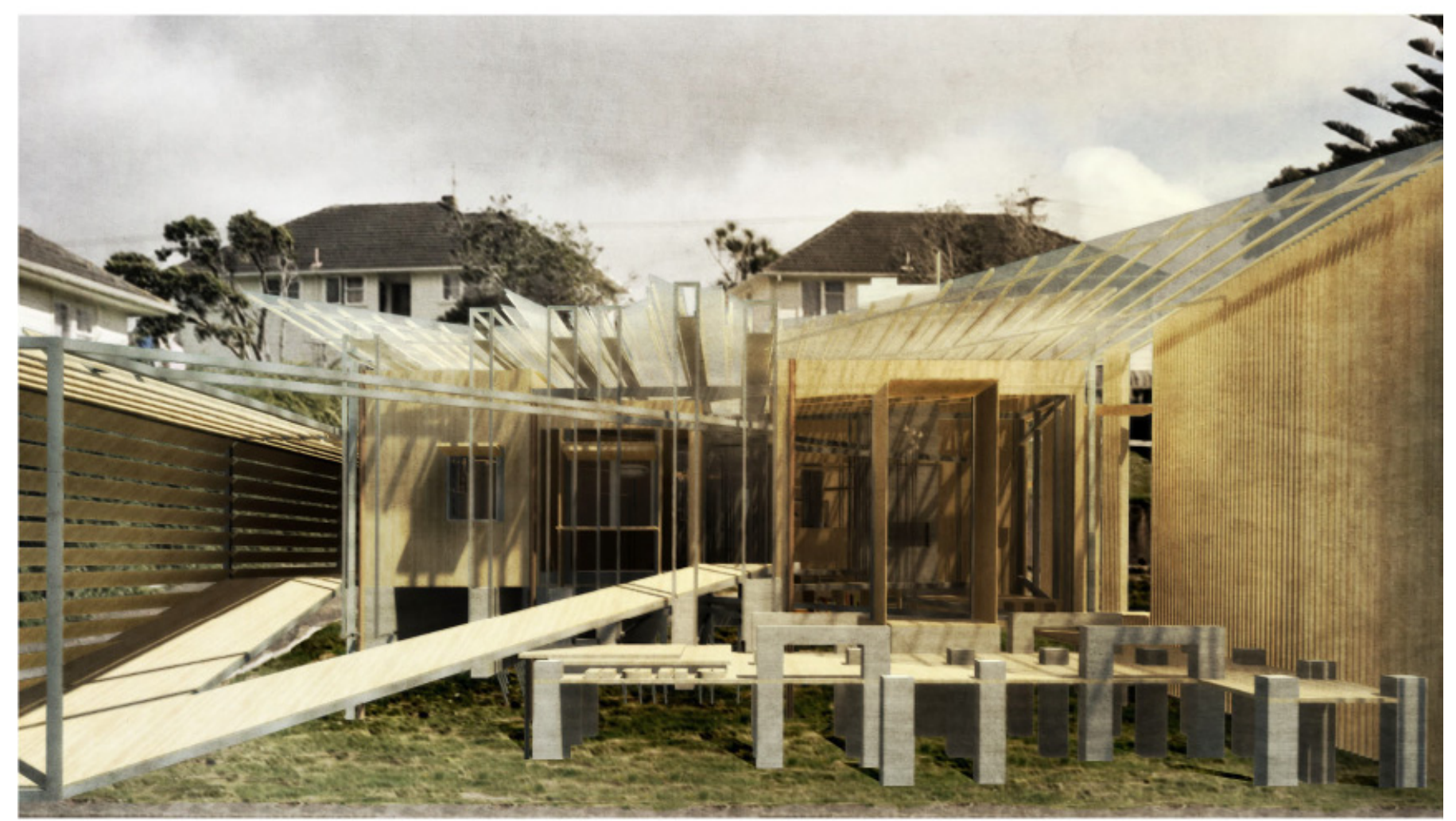

Figure 5.27 Front Elevation Behind Boundary Fence, Design Two. This image conveys the 'floating' effect of the rain-screen. Each interior space has its own roof in order to ensure weather-tightness, but the rain screen also serves as a rain-water collection system for the house. The roof is supported by a series of steel frames that connect the rain-screen to the foundations and wrap around the interactions of tapu that occur within the house. In this way the elements though which water flows over or through in the house wrap around the architecture to form a cleansing of tapu between the interior and exterior of the house. 
As the distance from the points of noa increases, a fracturing of form and of function takes hold within the architecture. Some spaces, such as the bedrooms and lounge area, retain specific functions due to the minimal clashes in tapu that occur within that area of the architecture (Fig.5.28-5.31). In other areas, conflicts in tapu begin to dominate the architecture, creating spaces that are more difficult to occupy, more difficult to define in terms of function, and that possess more dynamic and conflicting structural and constructional relationships. As a result, spaces such as the interior courtyards are formed, where panels and their supporting structures create an unease or difficulty for occupation, both in terms of function and formal clarity (Fig.5.32-5.33).

The shape of each of the panels is not arbitrary, but taken from the initial experimental drawing generated in experiment two, Chapter four, and conveys the interaction between different tapu within the space. The panels are wooden, and the substructure that supports them and ties them to the primary concrete structure is steel, in order to reflect the conceptual change in spatial quality that occurs when the distance from areas of noa increases. The gradation of concrete-steel-wood, therefore, corresponds to the conceptual relationship between calm/stable-interaction-chaos/unstable. The wooden panels reflect the different types of tapu in their most pure or un-interacted form. As each of the different types of tapu expressed within the architecture is based upon a particular spatial practice of the human occupants, the panels act as a series of moveable blinds or platforms to reflect the change in spatial practices within the house when they occur. The steel substructure communicates the interaction between the different types of tapu, and their relationship to the concrete noa elements, within the house. 


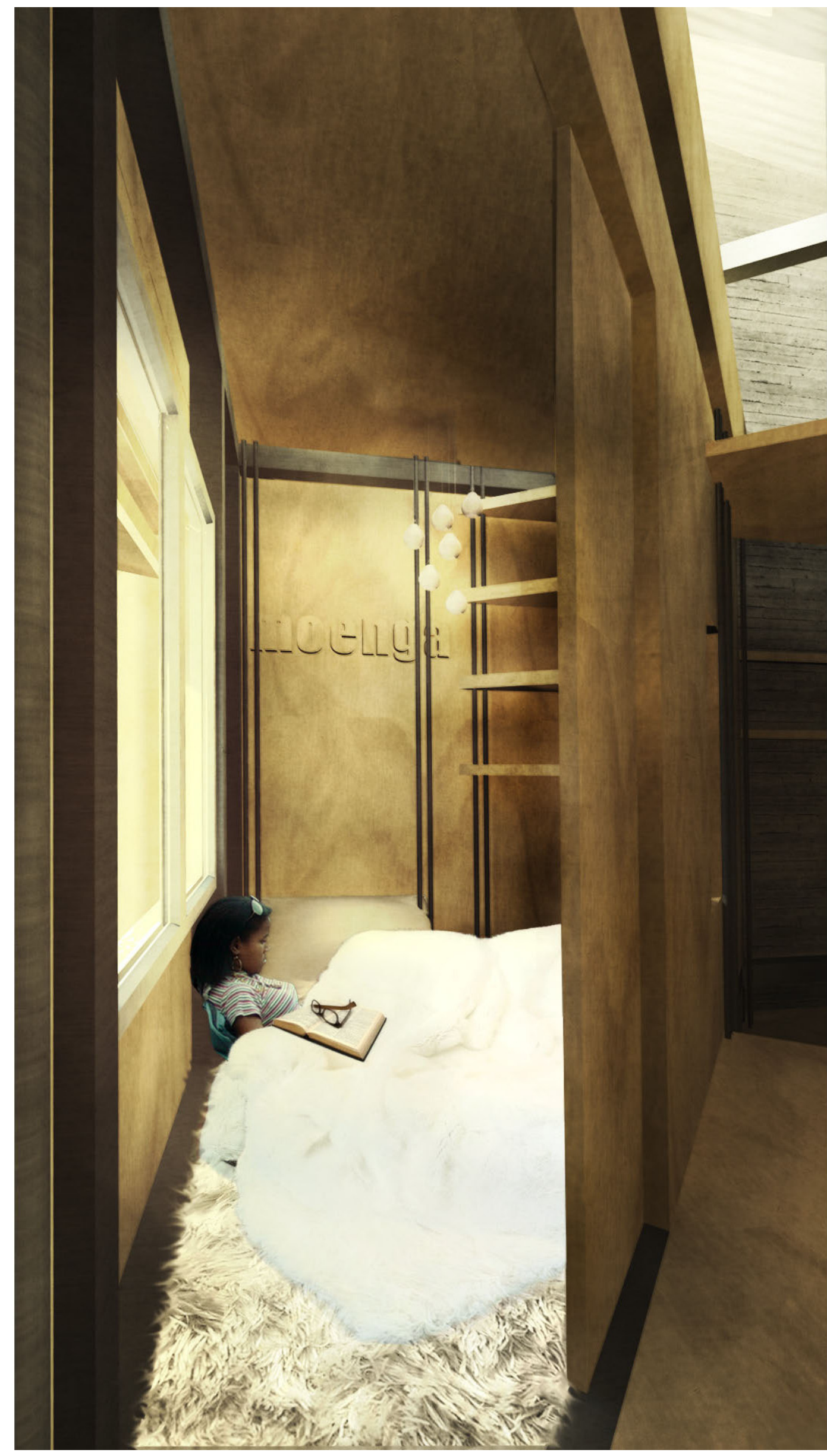

Figure 5.28 Interior Perspective of Children's Bedroom, Design Two. The bedrooms occupy the spaces within the site unaffected by other spatial practices. They therefore retain only some semblance of their former dimensions, and form triangular alcove like spaces. They are intended to operate as sleeping alcoves rather than full bedrooms, with additional storage being provided within the extended living/guest bedroom space, although some minimal shelving is provided within each alcove. The floor treatment within the bedroom alcoves is constructed from a series of triangular mattresses which are recessed into the floor so that the top level of the 'bed' lies at the level of the floor to convey the relationship between people and Papatuanuku as they rest on her. 


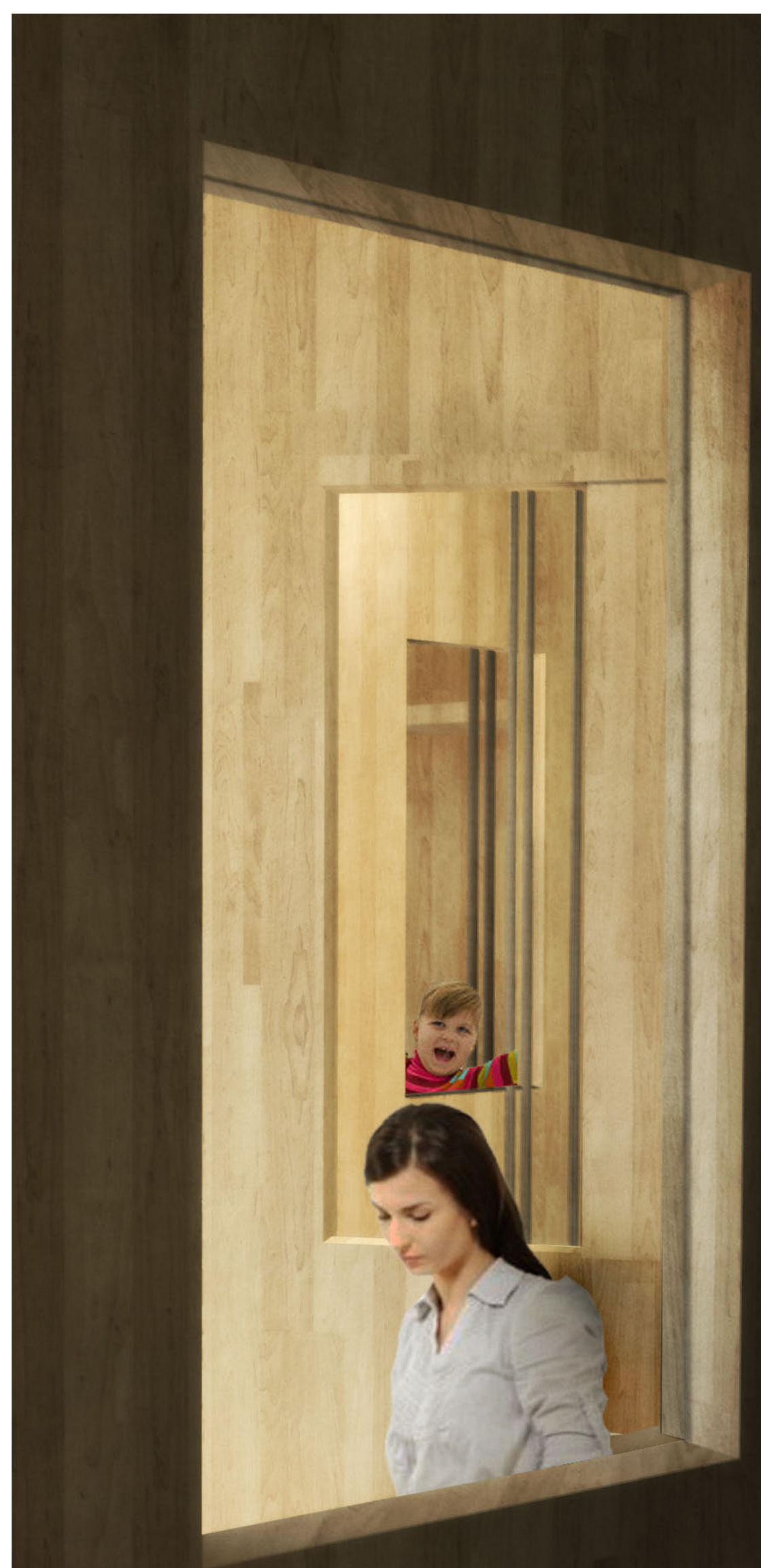

Figure 5.29 Interior Perspective of View-shaft Between Bedrooms, Design Two. The bedrooms are linked together through a series of small view shafts that 'slice' through the bedroom walls through a series of sliding windows, conveying the link between them enforced through their common tapu. 


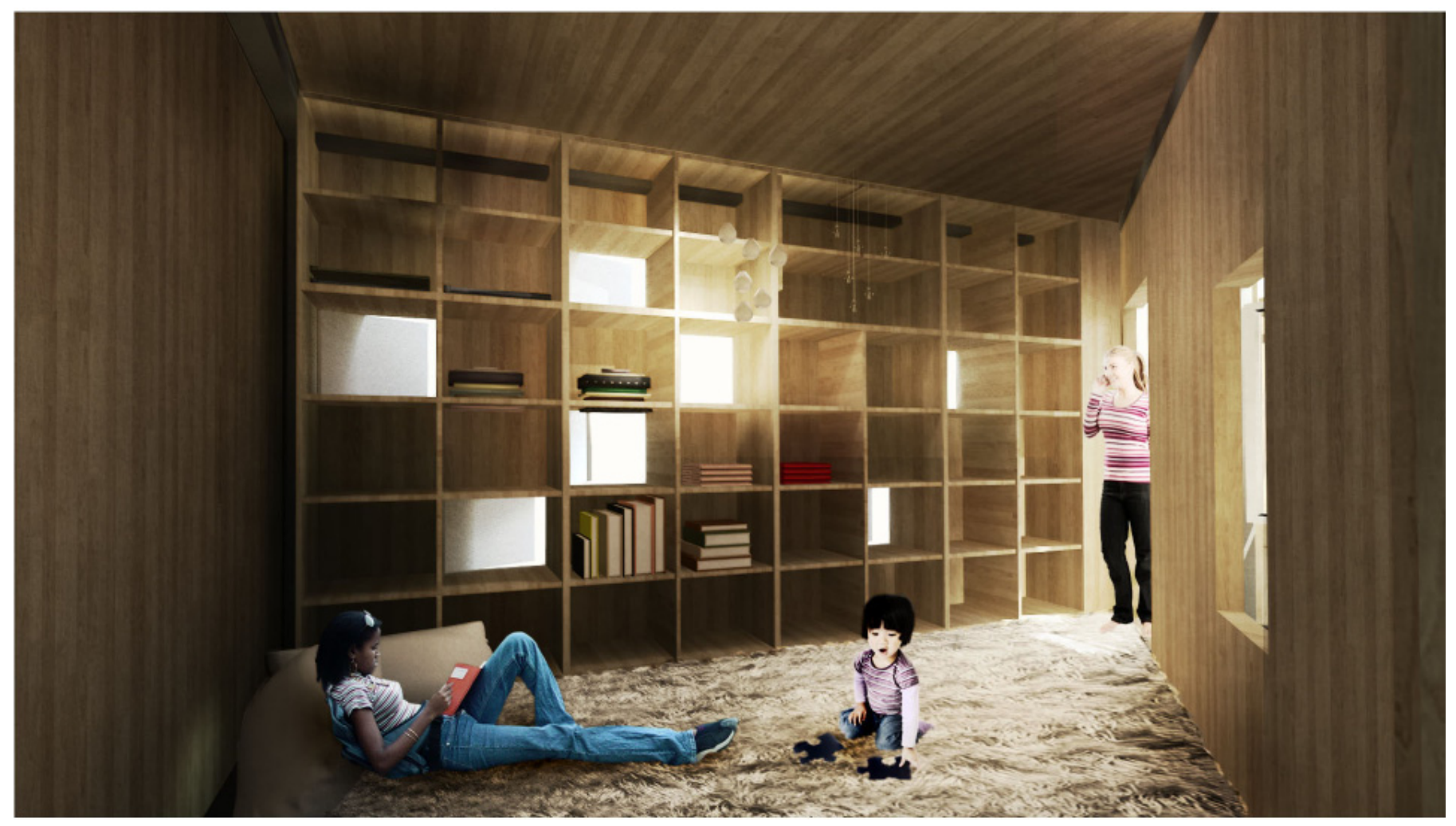

Figure 5.30 Interior Perspective of Guest Bedroom, Design Two. This bedroom is slightly different to the other in that it is meant to provide the ability to accommodate sleeping guests, but also be able to be used as an extended living/play space off the children's bedrooms, and provide extra storage within the house.

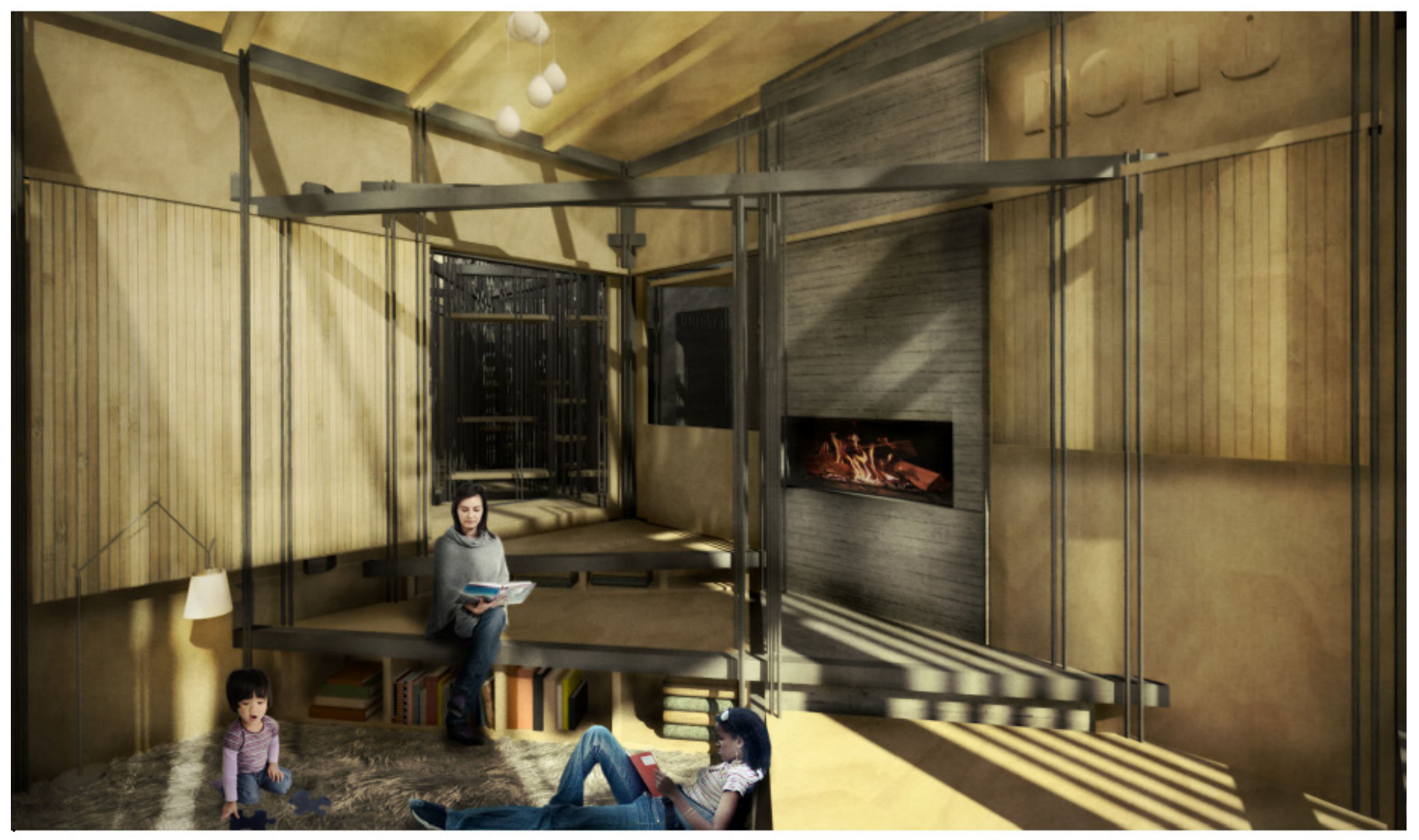

Figure 5.31 Interior Perspective of Living Area, Design Two. The living area is able to be opened to or shut off from the interior courtyard and exterior living areas by a series of sliding doors, windows, and shutter systems. The room experiences the conflict between the different tapu operating within the house, and the state of noa within the fireplace, resulting in a space which is able to be occupied and used as a lounge but is more conflicting than the pure noa concrete spaces of the bathroom, toilet, and washroom. 


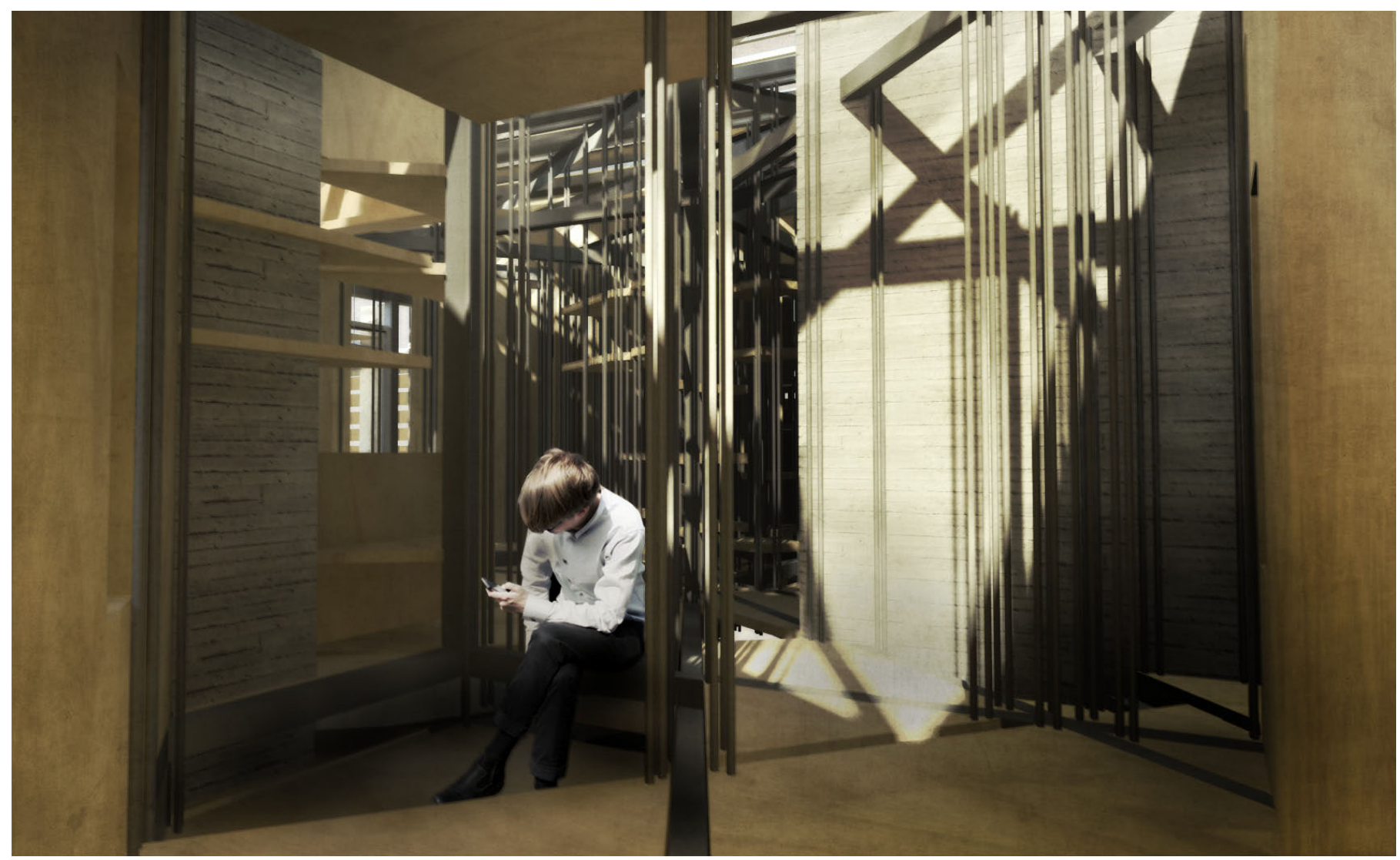

Figure 5.32 Interior Perspective of Bedroom Courtyard, Design Two. This area is an adjunct to the children's bedroom, and is open to the elements although sheltered by the rain-screen above the house. The panel at the above the occupant is able to be pulled down to form a table for the alcove he is sitting in.

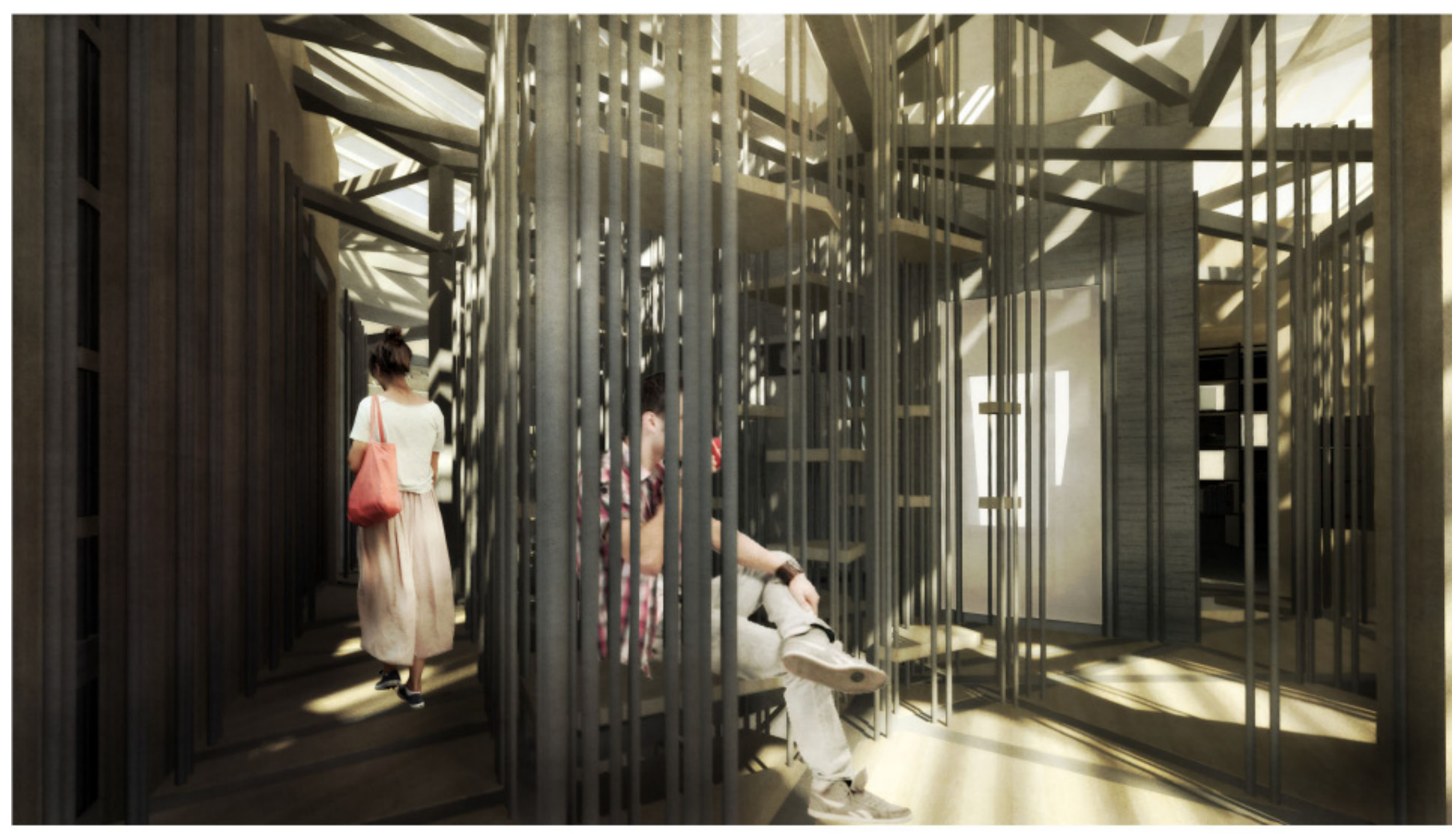

Figure 5.33 Interior Perspective of Hallway Courtyard, Design Two. This courtyard is exposed to the elements but covered by the transparent rainscreen above the house. It is within this space that the conflicts in tapu occurring within the house, and therefore the physical elements the represent them, most dominate the architecture, with wooden panels, and the steel rods that support them, clashing with the steel substructure of the house. This forms alcove like spaces that are more difficult to occupy and classify in terms of specific uses associated with traditional residential architecture. The wooden panels can be raised and lowered to create larger sitting areas or smaller arrangements of shelving and individual alcoves. 
The functions within the house are abstract reflections of the spatial practices prescribed by the original State House plan. They are not reflections of conventional domestic spaces (i.e. bedroom, lounge, kitchen), nor of their expected interior forms and spatial qualities, but of the spatial practices that occur within them. For example, the sleeping areas within the new architecture reflect not the fact that the space was a bedroom, but that the space has for many years, hosted the spatial practice of sleeping and, therefore, the interaction between the intrinsic tapu of a person and their place in Te Aō Marama with Te Po. It follows that the functions prescribed within the architectural outcome are not a simple continuation of the function and spatial structure prescribed by the original State House, but a more intimate reflection upon the presence and interaction between different types of tapu, and hence spatial practices, that occur within the space.

Certain elements within the design resulted from incorporating the recurring themes identified within the site analysis. For example, the front palisading elements form an emphasised boundary between the house, and the street aligns the house with current spatial practices in Eastern Porirua (Fig.5.34-5.36). Similarly, the increased adaptability of the house, generated through the moveable interior panels and exterior wall shutter systems, allows a greater appropriation of the architecture by the inhabitants and consequently a greater ability to adapt to changes in their spatial practices (Fig. 5.37-5.38). While certain spaces within the house are intimately linked to certain spatial practices (i.e. the sleeping areas within the house), the house as a whole is able to be appropriated by the inhabitants to suit the needs of a range of spatial practices. Additionally, the naming in te reo Mãori of practices associated with each space of the house references the influence of Māori narratives within the design and within the site (Fig.5.39-5.40).

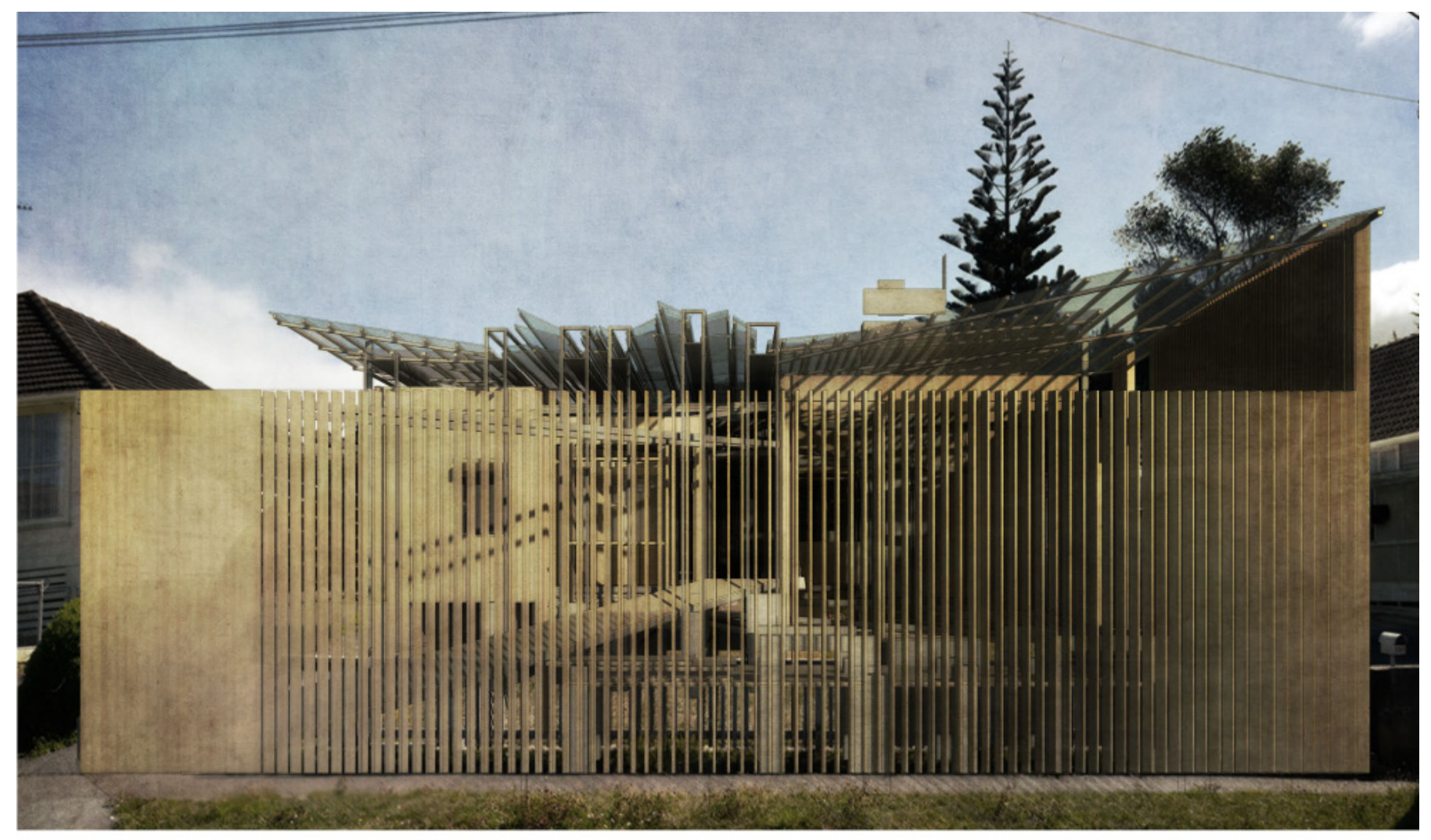

Figure 5.34 Front Street Elevation, Design Two. The fence that wraps around the exterior living areas of the house forms a palisading effect between the street and the house. 


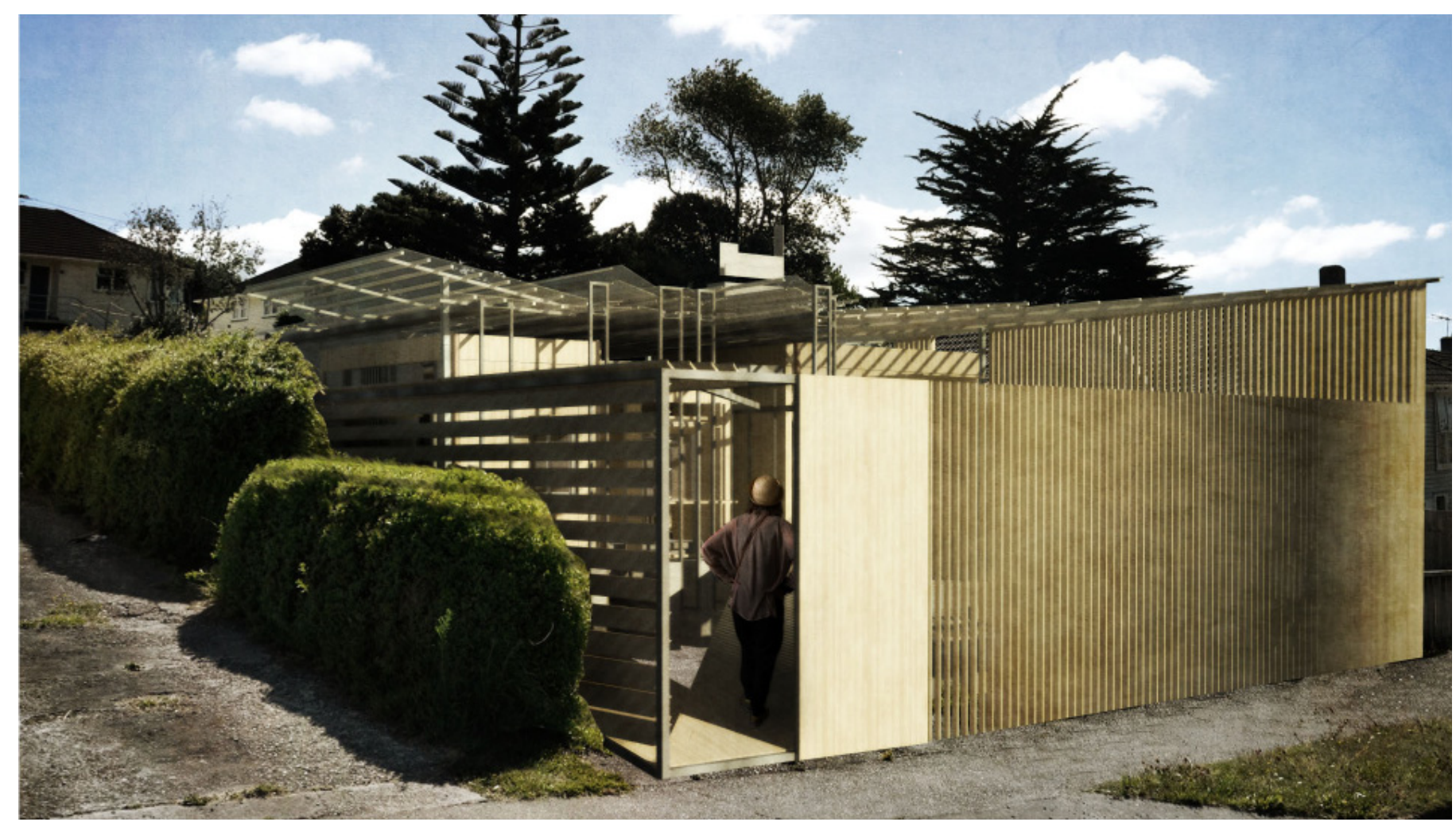

Figure 5.35 Exterior Perspective of Front Street Elevation, Design Two. Each wooden picket of the fence is rotated two degrees more than its neighbour, causing a blind like effect, which provides visual access, or creates the appearance of a solid wall, depending on the position the viewer in relation to the fence.
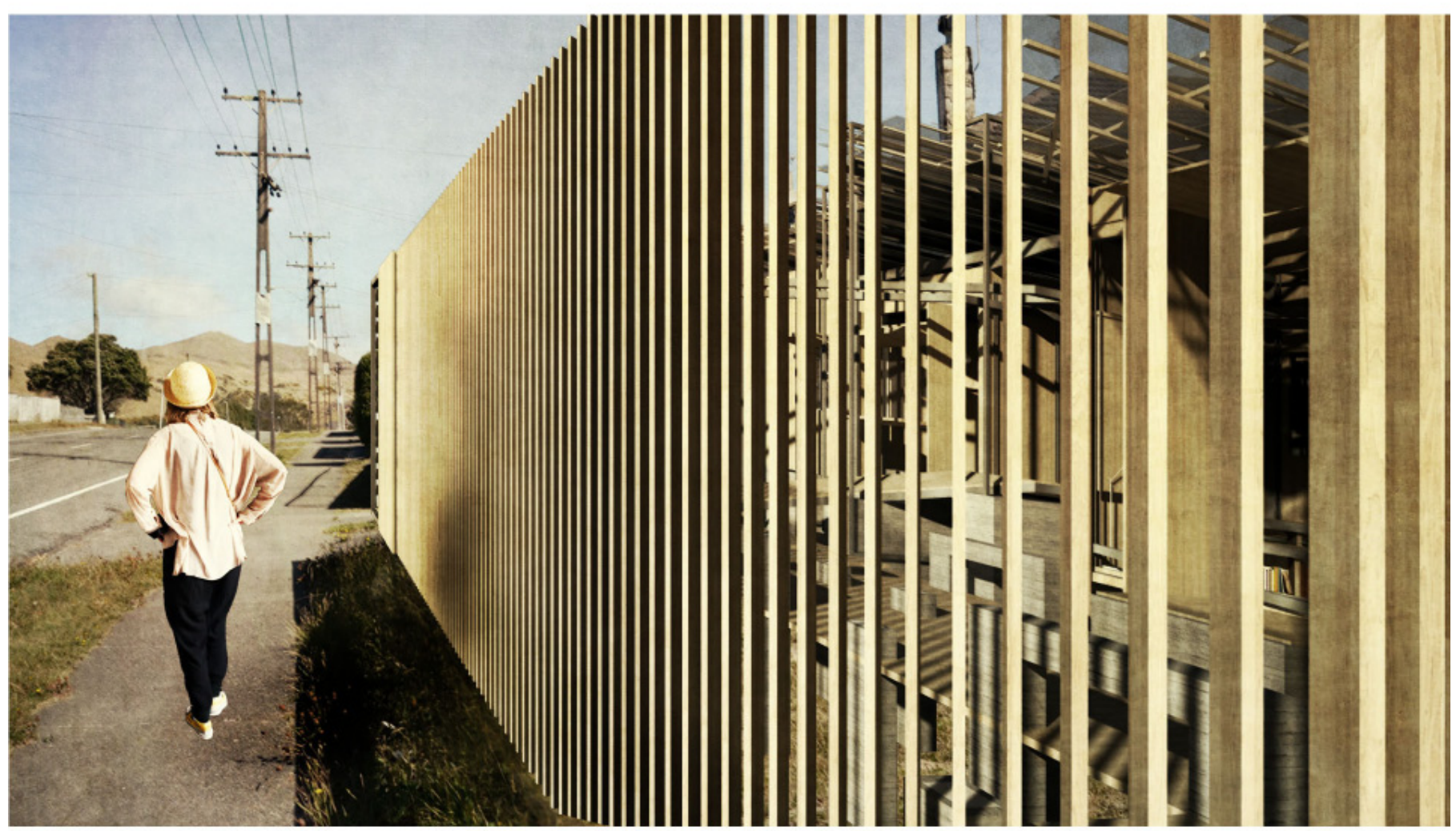

Figure 5.36 Exterior Perspective of Street Frontage, Design Two. Each wooden picket of the fence is rotated two degrees more than its neighbour, causing a blind like effect, which provides visual access or creates the appearance of a solid wall depending on the position of the viewer in relation to the fence, 


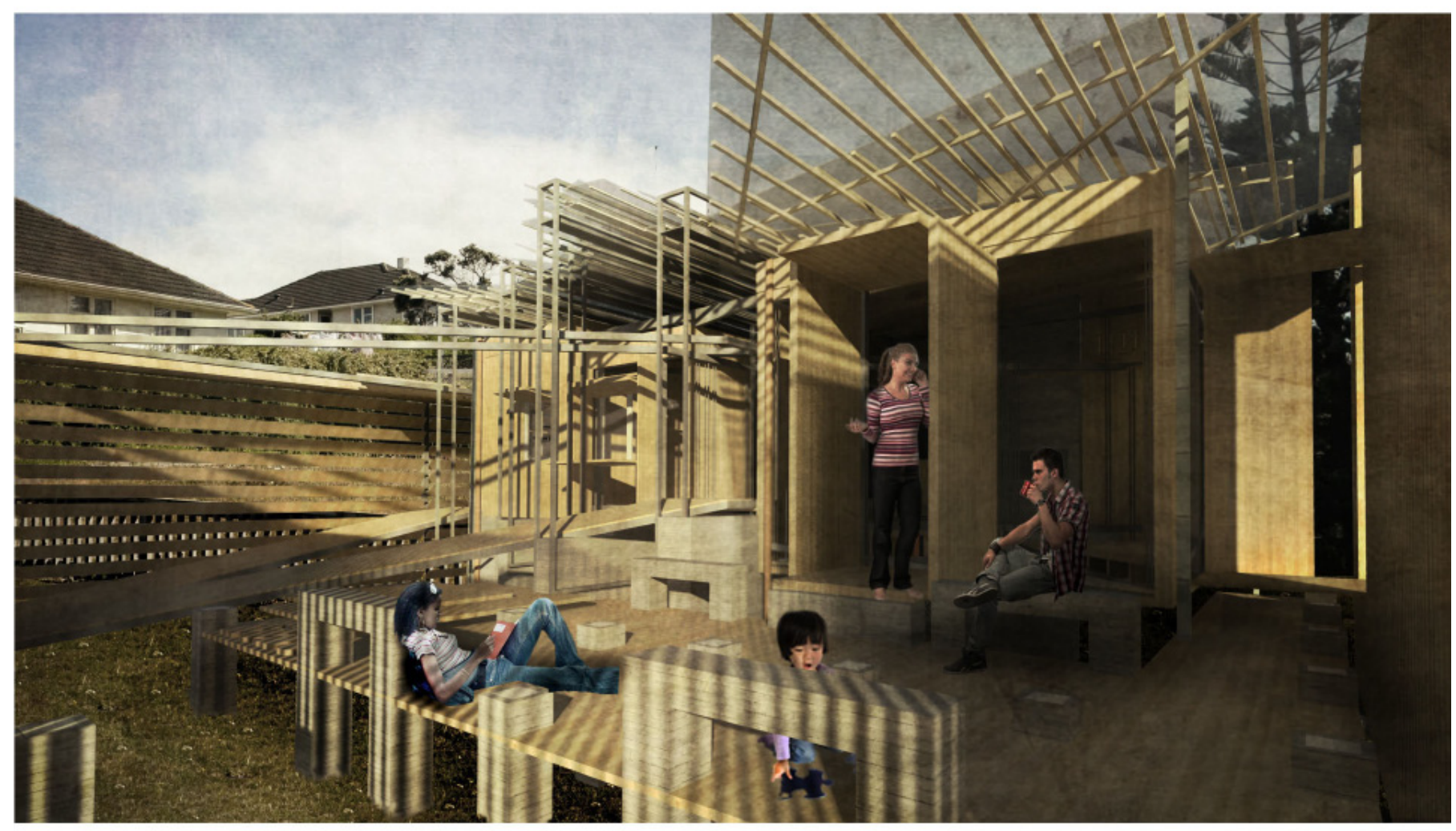

Figure 5.37 Exterior Perspective of Outdoor Living with House Wall Shutter Systems Open, Design Two. The timber panel shutter walls, constructed of timber framing, high density extruded polystyrene insulation, and treated plywood sheeting, open out onto the outdoor living areas. Behind the folding panels of the bedroom and kitchen, and the casement panel of the lounge located on the right hand side of this image are aluminium framed glazed windows, so these shutters can be opened without exposing the interior to the exterior environment.

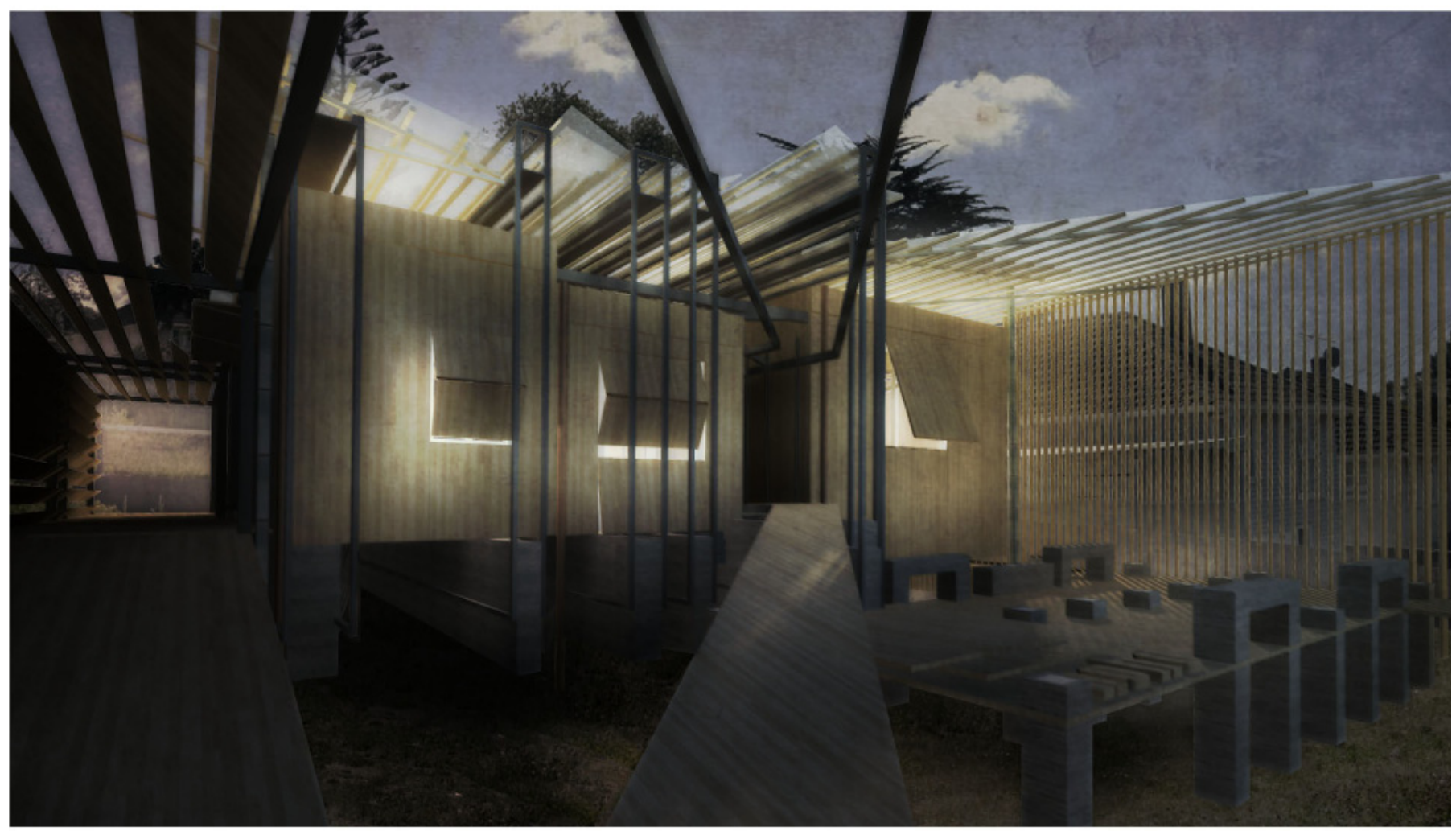

Figure 5.38 Night-time Exterior Perspective of Entrance and Outdoor Living Area with House Wall Shutter Systems Mostly Closed, Design Two. The shutters can be closed at night or in adverse weather to protect the inhabitants from the elements. 


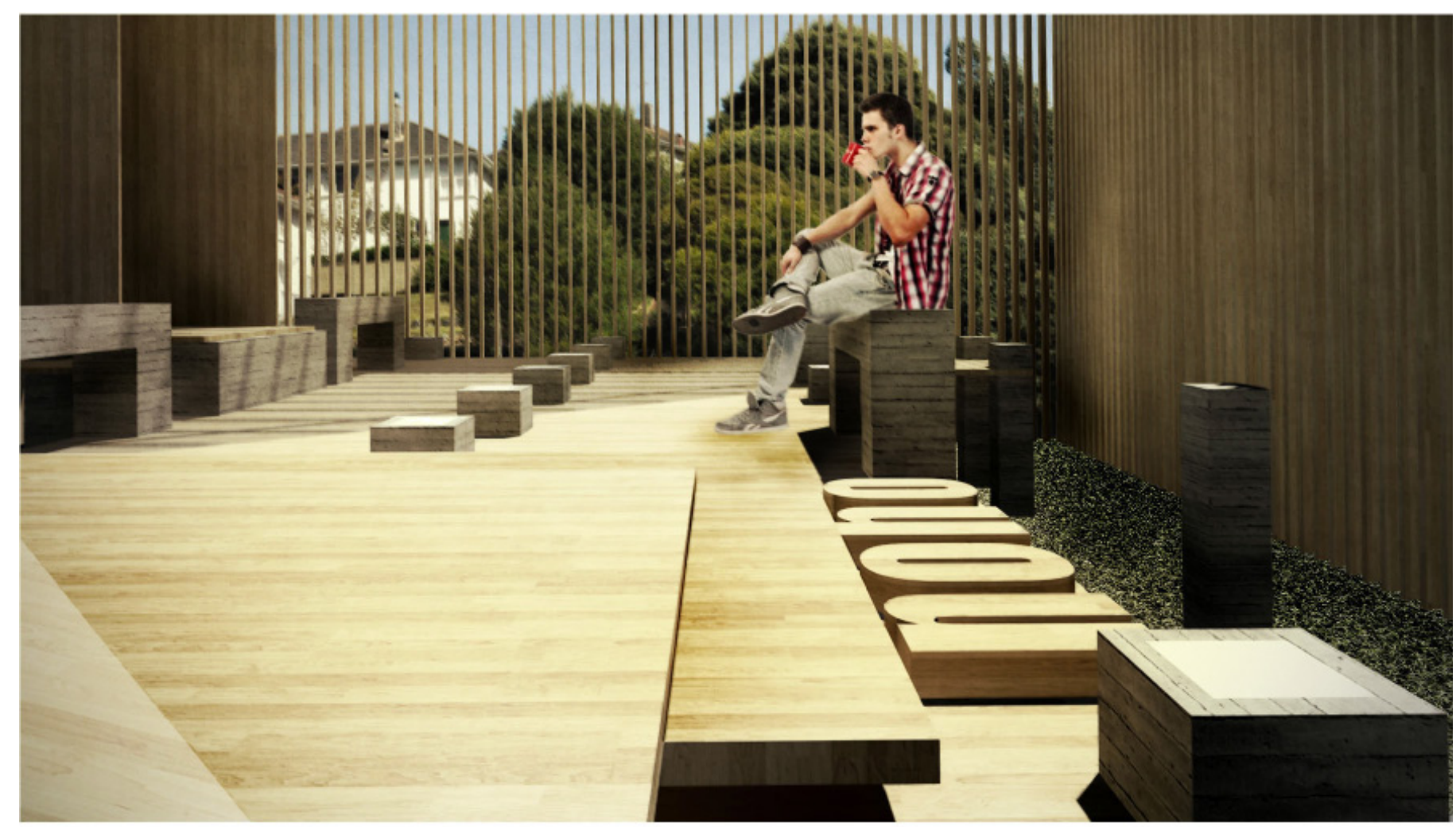

Figure 5.39 Exterior Detail Perspective of Te Reo Writing, Outdoor Living Area, Design Two. This perspective shows the detail of naming the outdoor living spaces within the house in te reo to reference the influence of Māori cultural narratives within the design process.

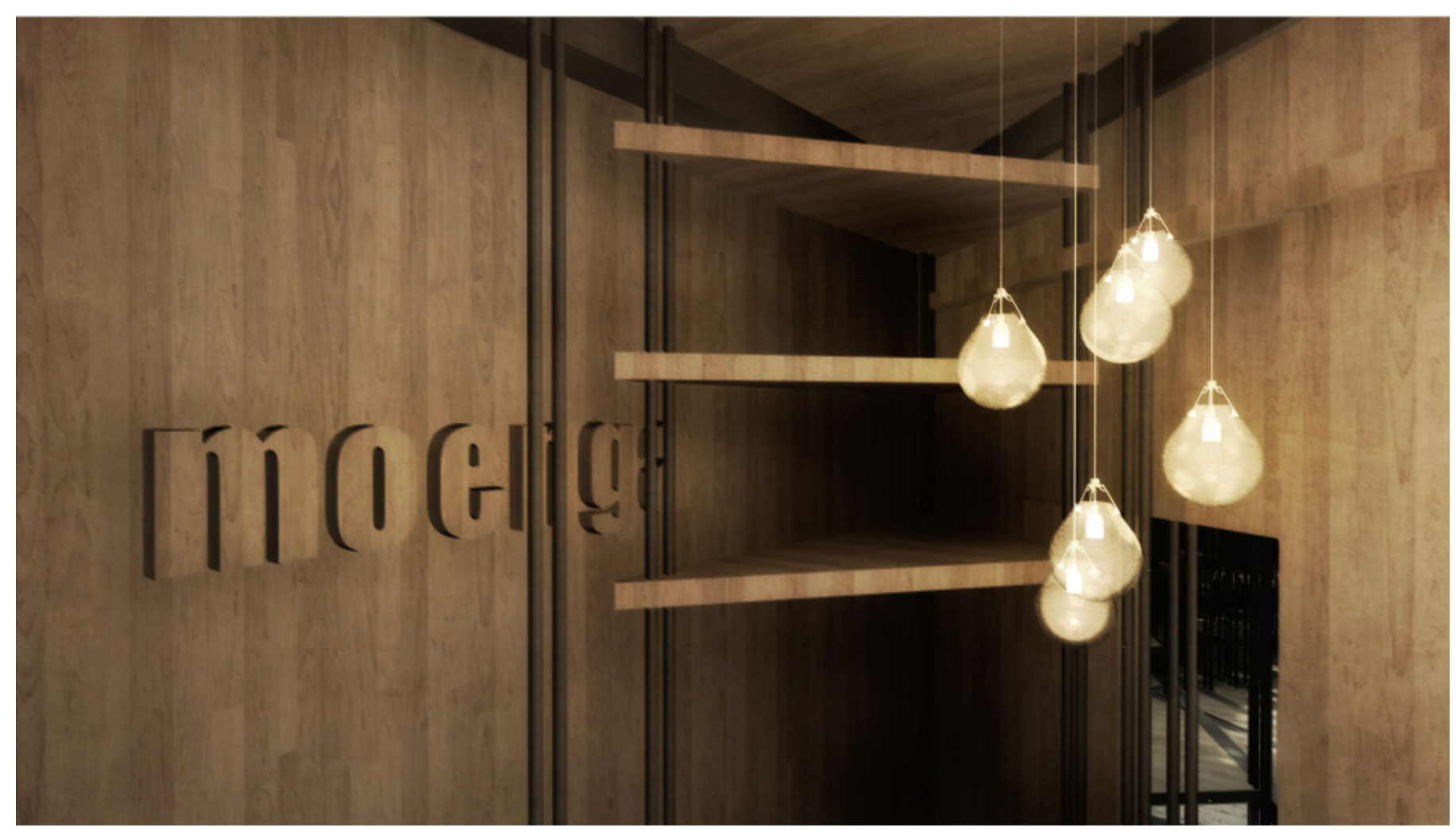

Figure 5.40 Interior Detail Perspective of Te Reo Writing, Washroom, Design Two. This perspective shows the detail of naming the interior bedroom spaces within the house in te reo to reference the influence of Māori cultural narratives within the design process. 
The finished architectural outcome is first and foremost one based upon the operation, conflict, and resolution of different tapu within the site. As each relationship of tapu is based on the operation of a specific spatial practice (i.e. the arrival, consumption, and removal of food from the site) the architectural elements more intimately reflect the spatial practices established within the site. In other words, the spatial practices established within the site define the architectural relationships. This is opposed to the repeated rectangular mathematical measurements and interior spatial structures that were used to define the original architecture of the State House that existed on the site. As a consequence the finished design outcome more intimately reflects the practice of living or dwelling within a suburban single family house, and conveys the conflicts that occur between divisions of function, privacy, and between exterior and interior. 



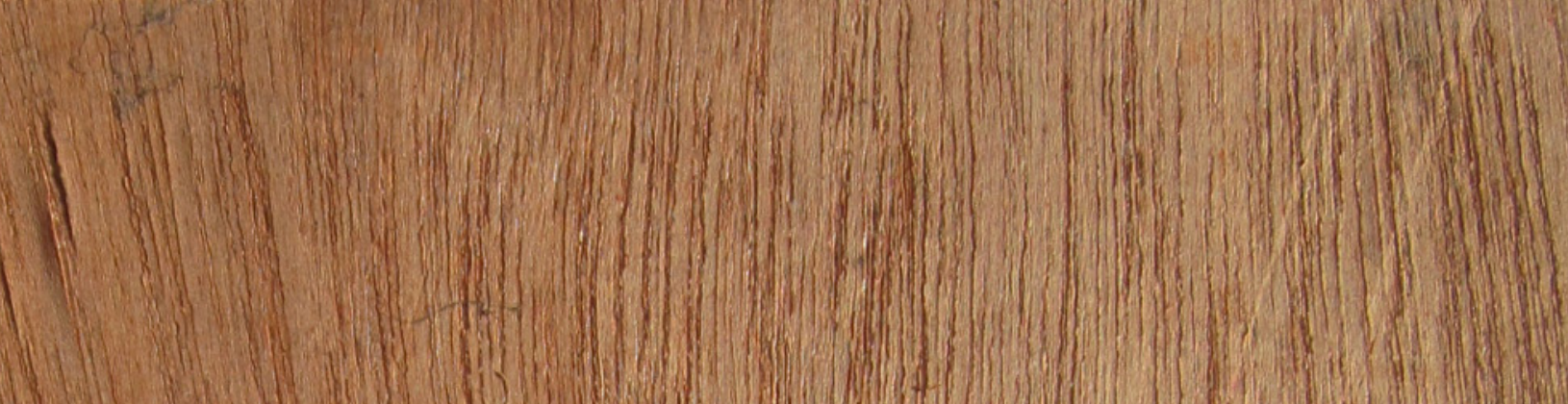




\section{Conclusion}

This thesis sought to achieve two distinct goals. The first was to understand how a canonical New Zealand architectural text, the State House, operated as an instrument of colonial power, and mediated colonial narratives surrounding space, culture and society. The method of analysis extended from post-structural and post-colonial literature, and applied the techniques used to read literary texts to the architectural text of the State House. The analysis formed two conclusions that informed the direction of the design-led research within the thesis. The first was that the mechanisms through which architecture is represented occupy a colonial position, and favour a western reading of space and building. Consequently, any shift towards a post-colonial architecture must challenge the authority of architectural mechanisms of representation as truthful and apolitical representations of space. The second conclusion was that through policy, spatial structure, and formal and aesthetic design, the State House operated as an imperial cultural object. The government used state housing as a tool to embed the preferred economic and cultural landscape of Pākehā society into the land, and to force the assimilation of Māori people into Pākehā culture under the rhetoric that it allowed them to elevate their living standards and levels of civility.

The second aim of this thesis was to investigate the possibilities of creating a new, what was termed postcolonial, position for contemporary residential architecture in New Zealand by challenging the colonial and imperial narratives mediated by architectural mechanisms of representation and the State House, for which the literature defined two distinct methods.

The first method extended from the literature of Bhahba and Lefebvre, and advocated for empirical research into how inhabitants themselves had challenged the colonial narratives of state house environments by actively living within them in ways not anticipated by the colonists/colonial power. These findings informed the extended site analysis undertaken in Chapter three, which established a list of key criteria to be integrated into the designs in order to align with current spatial practices and perceptions within the area.

The second method was to introduce previously suppressed cultural narratives in order to critique and challenge the authority of colonial narratives, and led to the two design-led experiments undertaken in Chapter four. The first experiment questioned the colonial position of architectural mechanisms of representation through engaging them with representations of wharenui. The second experiment used the Māori socio-spatial concept of tapu and noa in order to read the architecture of the State House.

The research found that, despite architectural mechanisms of representation occupying a colonial position, it is possible to challenge well-established colonial narratives by engaging them with alternative cultural architectural and socio-spatial narratives. These new positions can be labelled as post-colonial as they occupy a liminal position between two cultures, distinguishing them from a bi-cultural architectural position. Such a position allows them to operate as critiques of conventional narratives and expectations of contemporary residential architecture. By engaging with the architecture and cultural narratives embedded within the wharenui, the first design became a critique of the institution of threshold within the residential house, instituting threshold through a series of changes in spatial quality as opposed to solely physical elements and enclosed rooms. Similarly, through reading the State House as a series of socio-spatial interactions of tapu and noa, and allowing the spatial practices interactions within the site to define the architectural relationships of the house, as opposed to arbitrary, mathematical, and codified criteria and dimensions, the second, site-specific, design became a critique upon the relationship between the physical elements of architecture and the spatial practice of the suburban home.

The issues found within the research, and recommendations for future research, are as follows:

(1) Due to reasons of scope, the research was limited to using narratives from within Māori culture. Parallel investigations using narratives from Pacific Island and Asian cultural groups, among others, are needed in future. 
(2) The methods used within the experiments have a tendency to limit cultures to homogenous and recurring concepts and architectures. Future research is strongly encouraged to either rely on narratives already collectively established within a particular culture, or to restrict the narratives used to smaller scale groups or individuals (e.g. tribal, geographical, or community groups) in order to prevent the homogenising of diverse cultural groups.

(3) The assumption was made that the traditional or historically established narratives of space were still current. This is potentially misleading for the design as it assumes that traditional and established practices and ideologies are still held by contemporary inhabitants, whereas in reality they may think and live very differently. ${ }^{145}$ The incorporation of inhabitants' contemporary spatial practices and perceptions into the design development began to mitigate this issue, consequently creating a more responsive, practical, functional and therefore successful architectural outcome. However the empirical evidence used was limited to the exterior environment, and as a result largely failed to incorporate changes made to the interior of individual homes. Future research engaging with this method must aim to attain empirical evidence at this level of depth. This would be most easily achieved through architectural practice, where architects have direct access to clients. In the case of state housing, or other large developments and housing organisations, such research would be large in scale, and involve a significant investment of resources and rely on the involvement and support of Housing New Zealand Corporation.

Any shift in social, political or cultural ideology within society must be accompanied by a change in the practice of architecture in order to fully realise and complete social change. This view implies that architectural practice has an agency to enforce or critique social positions and ideologies. Contrary to this view, Tafuri argues that the position of modern architectural practice means that architectural practice and critique must be kept apart. ${ }^{146}$ Any attempt at relating them to each other is bound to fail because "practice is orientated towards novelty, whereas critique is always historical and seeks to recover original functions and ideologies." ${ }^{147}$ Tafuri's disjunction between practice and critique is in some ways similar to Lefebvre's distinction between the natures of the abstract space of the conceived and the dynamic nature of lived space. Architecture attempts to conceive of space, and prescribe spatial practices, through systems of signs and functions. It cannot escape the fact that it is produced from within the realm of spaces of representation, and that spatial practices and perceptions may (a) differ from those prescribed in the architectural plan, and (b) change over time.

Critically, Jameson traces a difference between Lefebvre's and Tafuri's beliefs on the ability to successfully generate critique through practice to two different lineages within Marxism. Unlike Tafuri, who believes any attempt to combine practice with critique is 'bound to fail', Jameson argues that Lefebvre sees new social relations evolving from within the mode of production they are going to surpass. ${ }^{148}$ This thesis aligns with Lefebvre's beliefs. Despite operating within the established mode of architectural design, the research achieved made three important evolutionary steps towards a new architectural position. The first of these is that it produced a critique through alternative cultural architectural and spatial narratives, despite these narratives becoming reframed by the colonial mechanisms/narratives they challenge. The second is that it enacted historical and traditional narratives as forms of critique to architectural practice, removing the disjunction highlighted by Tafuri. The third is that it incorporated evidence of the spatial practices and perceptions of lived space into design, minimising the disjunction between the abstract nature of architectural practice and the activity of everyday life.

\footnotetext{
145 For example, it was assumed that all of the bedrooms were used as bedrooms, and associated with the spatial practice of sleeping. Likewise, it was assumed that meals were eaten in the dining area within the kitchen prescribed by the original plan, and therefore, this area was associated in the final design as the point where noa is established through the consumption of cooked food. However, in reality the occupants would likely have shifted the spatial practices conventionally associated with each space. Likewise, it assumed that tapu and noa was still a practiced and important socio-spatial concept for Māori, whereas in reality many Māori may not practice tapu and noa based protocols and rituals.

146 Tafuri, 228

147 Tafuri, 228

148 Jameson, 72
} 



\section{Reference List: Ordered by Document Type}

\section{$\underline{\text { Books and Book Chapters }}$}

Aitken, Jonathan. Eastside: A contemporary view of Eastern Porirua. New Zealand: Jonathan Aitken Publishing, 2005.

Austin, Mike. "Maori” In Encyclopaedia of the Vernacular Architecture of the Wolrd, ed. Paul Oliver. New York: Cambridge University Press, 1997: 1215-1216.

Bhabha, Homi K. The Location of Culture. London: Routledge, 2004.

Bourdieu, Pierre. Distinction: A social critique of the judgement of taste [English]. Translated by Richard Nice. Cambridge: Harvard University Press, 2000.

Brookes, Barbara. "Nostalgia for 'Innocent Homely Pleasures': The 1964 New Zealand controversy over Washday at the Pa." In At Home in New Zealand: Houses, History, People, ed. Barbara Brookes. Wellington: Bridget Williams Books, 2000.

Byrnes, Giselle. Boundary Markers: Land surveying and the colonisation of New Zealand. Wellington: Bridget Williams Books, 2001.

Dovey, Kim. Framing Places: Mediating power in built form. London: Routledge, 2008.

Elden, Stuart. Understanding Henri Lefebvre. London: Continuum International Publishing Group, 2004.

Ferguson, Gael. Building the New Zealand Dream. Palmerston North: Dunmore Press with the assistance of the Historical Branch, Dept. of Internal Affairs, 1994.

Findley, Lisa. Building Change: Architecture, politics, and cultural agency. New York: Routledge, 2004.

Firth, Cedric Harold. State Housing in New Zealand. Wellington: Ministry of Works, 1949.

Foucault, Michel. Discipline and Punish: The birth of the prison [English]. Translated by Alan Sheridan. Harmondsworth: Penguin, 1979.

Gatley, Julia. “Going Up Rather than Out: State rental flats in New Zealand 1935-1949.” In At Home in New Zealand: Houses, History, People, ed. Barbara Brookes. Wellington: Bridget Williams Books, 2000.

Hancock, Lynne. "Maori: Whare hui (New Zealand)." In Encyclopaedia of the Vernacular Architecture of the Wolrd, ed. Paul Oliver. New York: Cambridge University Press, 1997:1217-1218

Hernandez, Felipe. Bhabha for Architects. London: Routledge, 2010.

Hillier, Bill. Space is the Machine: A configurational theory of architecture. Cambridge: Cambridge University Press, 1996.

Hillier, Bill, and Julienne Hanson. The Social Logic of Space. Cambridge: Cambridge University Press, 1984.

Isaac, Penny, and Erik Olssen. "The Justification for Labour's Housing Scheme: The discourse of 'the slum'.” In $A t$ Home in New Zealand: Houses, History, People, ed. Barbara Brookes. Wellington: Bridget Williams Books, 2000.

Jones, Paul. The Sociology of Architecture: Constructing identities. Liverpool: Liverpool University Press, 2011.

Knight, Cyril. 1840 and After. Auckland: Auckland University College Press, 1940.

Leach, Neil. Rethinking Architecture: A reader in cultural theory. New York: Routledge, 1996.

Lefebvre, Henri. Introduction to Modenity [English]. Translated by John Moore. London: Verso, 1995.

—. "Preface." In Philippe Boudon, Lived-in Architecture: Le Corbusier's Pessac revisited [English], translated by Gerald Onn. London: Lund Humphries, 1972. 
—. The Production of Space [English]. Translated by Donald Nicholson-Smith. Oxford: Blackwell, 1991.

Merrifield, Andy. Henri Lefebvre: A critical introduction. New York: Routledge, 2006.

Pool, Ian. Te Iwi Maori: A New Zealand population, past, present and projected. Auckland: Auckland University Press, 1991.

Said, Edward. Culture and Imperialism. New York: Knopf: Distributed by Random House, 1993.

Schmid, Christian. Stadt, Raum Und Gesellschaft: Henri Lefebvre und die theorie der produktion des raumes. Munich: Franz Steiner, 2005.

Schrader, Ben. "Labour at Home: The first Labour government and the familial suburban ideal." In At Home in New Zealand: Houses, History, People, ed. Barbara Brookes. Wellington: Bridget Williams Books, 2000.

—. We Call it Home: A history of state housing in New Zealand. Auckland: Reed, 2005.

Shaw, Peter. A History of New Zealand Architecture. Auckland: Hodder Moa Beckett Publishers Ltd, 2003.

Shields, Rob. "Henri Lefebvre." In Key Thinkers of Space and Place, eds. Rob Kitchin and Phil Hubbard. London: SAGE, 2010.

Stacpoole, John. Colonial Architecture in New Zealand. Wellington: Reed, 1976.

Stanek, Lukasz. Henri Lefebvre on Space: Architecture, urban research, and the production of theory. Minneapolis: University of Minnesota Press, 2011.

Tafuri, Manfredo. Theories and History of Architecture. London; New York: Grenada, 1980.

Toomath, William. Built in New Zealand: The houses we live in. Auckland: Harper Collins, 1996.

Venn, Couze. "Michel Foucault." In The Wiley-Blackwell Companion to Major Social Theorists, eds. George Ritzer and Jeffrey Stepnisky. Malden: Wiley-Blackwell, 2011.

Walker, Ranignui. Ka Whawhai Tonu Matou = Struggle Without End. Auckland: Penguin, 2004.

\section{Journal Articles and Research Papers}

Austin, Mike. “A Description of the Maori Marae.” Study Paper, Auckland: University of Auckland, 1980.

—. "Biculturalism and Architecture in Aotearoa/New Zealand.” National Identities 5, no. 1 (2003): 44-48.

Building Progress. "Test Houses - Plans and Comments: Wilson and Hammond - Designs differ in approach." Building Progress, (September 1953): 3-8.

Jameson, Frederick. "Architecture and the Critique of Ideology." In The Ideologies of Theory: Essays 1971-1986 Vol.2. Minneapolis: University of Minnesota Press, (1988): 35-60.

Kerr, P. “The Face of a Building." Heritage New Zealand, (2007): 10-15.

Linzey, Mike. "On the Pointing Signification of the Meeting House." Fabrications 14, no. $1 \& 2$ (2004): 13-19.

Salmond, Anne. "Te Ao Tawhito: A semantic approach to the traditional Maori cosmos." Journal of the Polynesian Society 87 (1978): 5-28.

Schmidt, Tyson. "Reading Ruatoria and its Rastifarians: The construction of contesting identities through architecture and landscape in Children of Zion.” Unpublished Research Paper, (2007).

Seager, Samuel Hurst. “Architectural Art in New Zealand.” RIBA II/19 (1900): 490.

Shirres, Michael P. “Tapu.” Journal of the Polynesian Society 91 (1982): 29-52. 
Smith, Jean. "Memoir No. 40: Tapu Removal in Maori Religion: Parts One and Two." Journal of the Polynesian Society 84 (1975): 1-96.

Walker, Ranginui. "Mana and Identity.” Historic Places, (1990): 4-9.

Wilson, Gordon. "Full Report on Wilson House." Home and Building, (September 1953): 28.

Wilson, Gordon, and Reginald Hammond. "Low-cost Houses: Designers' explanations to cabinet." Building Progress, (1953): 8.

\section{Reports and Studies}

Boffa Miskeel ltd. and Graeme McIndoe Architect \& Urban Designer. Porirua Sububran Character Study. Porirua: Porirua City Council, 2005.

Housing New Zealand Corporation. Community Renewal Programme Evaluation - April 2008. April 2008. http:// www.hnzc.co.nz/about-us/research-and-policy/housing-research-and-evaluation/summaries-of-reports/communityrenewal-programme-evaluation-april-2008/ (accessed August 15, 2012).

Hunn, Jack. Report on Department of Maori Affairs. Government Report, Wellington: R.E. Owen: Government Printer, 1961.

Jones, Warren. People and Places: An Eastside story: Project exit report. Wellington: Housing New Zealand Corporation, 2004.

MacDonald, Judith. Racism and Rental Accomodation: A Report for the Office of the Race Relations Conciliator. Government Report, Auckland: Social Research and Development Trust, 1986.

Rau Hoskins Design. Ki Te Hau Kainga: New perspectives on Maori housing solutions. A design guide prepared for Housing New Zealand Corporation, Auckland: Rau Hoskins Design, 2002.

\section{Online Resources}

New Zealand History Online. The Treaty House at Waitangi. n.d. http://www.nzhistory.net.nz/politics/treaty/ waitangi-day/the-treaty-house (accessed August 23, 2012).

Statistics New Zealand. "Cannons Creek East Community Profile.” Statistics New Zealand. May 30, 2003. http:// www2.stats.govt.nz/domino/external/web/commprofiles.nsf/printing/23A3150BEFF630C0CC256D2B00763B07 (accessed March 5, 2012).

—. "Cannons Creek North Community Profile." Statistics New Zealand. May 30, 2003. http://www2.stats.govt.nz/ domino/external/web/commprofiles.nsf/printing/2239AD6AA654F7BCCC256D2B00763973 (accessed March 5, 2012).

—. “Cannons Creek South Community Profile.” Statistics New Zealand. May 30, 2003. http://www2.stats.govt.nz/ domino/external/web/commprofiles.nsf/printing/C5523E33C1950BDCCC256D2B00763A3D (accessed March 5, 2012).

Te Ahukaramu, Charles Royal. "Te Ao Marama - The natural world: The world of light and darkness.” March 10, 2009. URL: http://www.TeAra.govt.nz/en/te-ao-marama-the-natural-world/3 (accessed August 20, 2012).

\section{Films and Television Shows}

“Housing in New Zealand [video recording].” Directed by Department of Housing Construction. 1946.

“Inside Child Poverty: A Special Report.” Television Programme. Directed by Mediaworks TV, 2011.

"People and Places: An Eastside story [documentary film].” Directed by Housing New Zealand Corporation \& Housing Action Group Porirua. 2004. 


\section{Archived Documents}

Greater Wellington Regional Council [ADIF]. "Plan Showing the Probable General Development of the Areas about Porirua and Pauatahanui (April 1948, R.P.A. [Regional Planning Authority] Print, Tracing xC11/2, 20 chains)", Container code: C607874, Archives Ref. No. ADIF W3993 Box 7, Rec. No. xC11/2, 1948, accessed on $6 / 7 / 2012$.

—. "Planning Data Map - Porirua Borough as at November 1963", Container code: C607876, Archives Ref. No. ADIFW3993 Box 9, Rec. No. x3/2/3/C, 1963, accessed on 6/7/2012.

Housing Corporation of New Zealand, Head Office [AALF]. "Photographs of State Housing Plans", Container code: C 398 664, Ref. No. AALF W1559 6114 Box 1, undated, accessed on 30/4/2012.

—. "Proposed Development, Porirua”, Container code: C398662, Archives Ref. No. AALF W15596112 Box 3, Rec. No. 20/14, undated, accessed on 20/3/2012.

—. "Porirua Development", Container code: C398662, Archives Ref. No. AALF W15596112 Box 3, Rec. No. 20/15, undated, accessed on 21/3/2012.

Housing Corporation of New Zealand, Wellington District Office [AAQV]. "Photographic Records, Maps, Plans of Porirua and Whitby Developments: [b/w photographs - aerials and of house and buildings in and around Porirua]", Container code: C554182, Archives Ref. No. AAQV W3361 Box 1, undated, accessed on 20/4/2012.

Ministry of Works, Housing Division [AAPO]. "Wellington - Johnsonville; Porirua; Titahi Bay [3 maps], Container code: C425012, Archives Ref. No. AAPO W1100 6489 Box 11, undated, accessed on 20/3/2012. 


\section{Reference List: Ordered Alphabetically}

Aitken, Jonathan. Eastside: A contemporary view of Eastern Porirua. New Zealand: Jonathan Aitken Publishing, 2005.

Austin, Mike. "Maori” In Encyclopaedia of the Vernacular Architecture of the Wolrd, ed. Paul Oliver. New York: Cambridge University Press, 1997: 1215-1216.

—. "A Description of the Maori Marae." Study Paper, Auckland: University of Auckland, 1980.

—. "Biculturalism and Architecture in Aotearoa/New Zealand.” National Identities 5, no. 1 (2003): 44-48.

Bhabha, Homi K. The Location of Culture. London: Routledge, 2004.

Boffa Miskeel ltd. and Graeme McIndoe Architect \& Urban Designer. Porirua Sububran Character Study. Porirua: Porirua City Council, 2005.

Bourdieu, Pierre. Distinction: A social critique of the judgement of taste [English]. Translated by Richard Nice. Cambridge: Harvard University Press, 2000.

Brookes, Barbara. "Nostalgia for 'Innocent Homely Pleasures': The 1964 New Zealand controversy over Washday at the Pa." In At Home in New Zealand: Houses, History, People, ed. Barbara Brookes. Wellington: Bridget Williams Books, 2000.

Building Progress. "Test Houses - Plans and Comments: Wilson and Hammond - Designs differ in approach." Building Progress, (September 1953): 3-8.

Byrnes, Giselle. Boundary Markers: Land surveying and the colonisation of New Zealand. Wellington: Bridget Williams Books, 2001.

Dovey, Kim. Framing Places: Mediating power in built form. London: Routledge, 2008.

Elden, Stuart. Understanding Henri Lefebvre. London: Continuum International Publishing Group, 2004.

Ferguson, Gael. Building the New Zealand Dream. Palmerston North: Dunmore Press with the assistance of the Historical Branch, Dept. of Internal Affairs, 1994.

Findley, Lisa. Building Change: Architecture, politics, and cultural agency. New York: Routledge, 2004.

Firth, Cedric Harold. State Housing in New Zealand. Wellington: Ministry of Works, 1949.

Foucault, Michel. Discipline and Punish: The birth of the prison [English]. Translated by Alan Sheridan. Harmondsworth: Penguin, 1979.

Gatley, Julia. “Going Up Rather than Out: State rental flats in New Zealand 1935-1949.” In At Home in New Zealand: Houses, History, People, ed. Barbara Brookes. Wellington: Bridget Williams Books, 2000.

Greater Wellington Regional Council [ADIF]. "Plan Showing the Probable General Development of the Areas about Porirua and Pauatahanui (April 1948, R.P.A. [Regional Planning Authority] Print, Tracing xC11/2, 20 chains)", Container code: C607874, Archives Ref. No. ADIF W3993 Box 7, Rec. No. xC11/2, 1948, accessed on 6/7/2012.

—. "Planning Data Map - Porirua Borough as at November 1963", Container code: C607876, Archives Ref. No. ADIFW3993 Box 9, Rec. No. x3/2/3/C, 1963, accessed on 6/7/2012.

Hancock, Lynne. "Maori: Whare hui (New Zealand)." In Encyclopaedia of the Vernacular Architecture of the Wolrd, ed. Paul Oliver. New York: Cambridge University Press, 1997:1217-1218

Hernandez, Felipe. Bhabha for Architects. London: Routledge, 2010.

Hillier, Bill. Space is the Machine: A configurational theory of architecture. Cambridge: Cambridge University Press, 1996. 
Hillier, Bill, and Julienne Hanson. The Social Logic of Space. Cambridge: Cambridge University Press, 1984.

Housing Corporation of New Zealand, Head Office [AALF]. "Photographs of State Housing Plans", Container code: C 398 664, Ref. No. AALF W1559 6114 Box 1, undated, accessed on 30/4/2012.

—. "Proposed Development, Porirua", Container code: C398662, Archives Ref. No. AALF W15596112 Box 3, Rec. No. 20/14, undated, accessed on 20/3/2012.

—. "Porirua Development", Container code: C398662, Archives Ref. No. AALF W15596112 Box 3, Rec. No. 20/15, undated, accessed on 21/3/2012.

Housing Corporation of New Zealand, Wellington District Office [AAQV]. "Photographic Records, Maps, Plans of Porirua and Whitby Developments: [b/w photographs - aerials and of house and buildings in and around Porirua]", Container code: C554182, Archives Ref. No. AAQV W3361 Box 1, undated, accessed on 20/4/2012.

“Housing in New Zealand [video recording].” Directed by Department of Housing Construction. 1946.

Housing New Zealand Corporation. Community Renewal Programme Evaluation - April 2008. April 2008. http:// www.hnzc.co.nz/about-us/research-and-policy/housing-research-and-evaluation/summaries-of-reports/community-renewal-programme-evaluation-april-2008/ (accessed August 15, 2012).

Hunn, Jack. Report on Department of Maori Affairs. Government Report, Wellington: R.E. Owen: Government Printer, 1961.

“Inside Child Poverty: A Special Report.” Television Programme. Directed by Mediaworks TV, 2011.

Isaac, Penny, and Erik Olssen. “The Justification for Labour's Housing Scheme: The discourse of 'the slum'.” In $A t$ Home in New Zealand: Houses, History, People, ed. Barbara Brookes. Wellington: Bridget Williams Books, 2000.

Jameson, Frederick. "Architecture and the Critique of Ideology." In The Ideologies of Theory: Essays 1971-1986 Vol.2. Minneapolis: University of Minnesota Press, (1988): 35-60.

Jones, Paul. The Sociology of Architecture: Constructing identities. Liverpool: Liverpool University Press, 2011.

Jones, Warren. People and Places: An Eastside story: Project exit report. Wellington: Housing New Zealand Corporation, 2004.

Kerr, P. “The Face of a Building.” Heritage New Zealand, (2007): 10-15.

Knight, Cyril. 1840 and After. Auckland: Auckland University College Press, 1940.

Lefebvre, Henri. Introduction to Modenity [English]. Translated by John Moore. London: Verso, 1995.

—. "Preface." In Philippe Boudon, Lived-in Architecture: Le Corbusier's Pessac revisited [English], translated by Gerald Onn. London: Lund Humphries, 1972.

—. The Production of Space [English]. Translated by Donald Nicholson-Smith. Oxford: Blackwell, 1991.

Linzey, Mike. “On the Pointing Signification of the Meeting House.” Fabrications 14, no. 1\&2 (2004): 13-19.

MacDonald, Judith. Racism and Rental Accomodation: A Report for the Office of the Race Relations Conciliator. Government Report, Auckland: Social Research and Development Trust, 1986.

Merrifield, Andy. Henri Lefebvre: A critical introduction. New York: Routledge, 2006.

Ministry of Works, Housing Division [AAPO]. "Wellington - Johnsonville; Porirua; Titahi Bay [3 maps], Container code: C425012, Archives Ref. No. AAPO W1100 6489 Box 11, undated, accessed on 20/3/2012.

New Zealand History Online. The Treaty House at Waitangi. n.d. http://www.nzhistory.net.nz/politics/treaty/waitangi-day/the-treaty-house (accessed August 23, 2012). 
“People and Places: An eastside story [documentary film]." Directed by Housing New Zealand Corporation \& Housing Action Group Porirua. 2004.

Pool, Ian. Te Iwi Maori: A New Zealand population, past, present and projected. Auckland: Auckland University Press, 1991.

Rau Hoskins Design. Ki Te Hau Kainga: New perspectives on Maori housing solutions. A design guide prepared for Housing New Zealand Corporation, Auckland: Rau Hoskins Design, 2002.

Said, Edward. Culture and Imperialism. New York: Knopf: Distributed by Random House, 1993.

Salmond, Anne. "Te Ao Tawhito: A semantic approach to the traditional Maori cosmos." Journal of the Polynesian Society 87 (1978): 5-28.

Schmidt, Tyson. "Reading Ruatoria and its Rastifarians: The construction of contesting identities through architecture and landscape in Children of Zion.” Unpublished Research Paper, (2007).

Schmid, Christian. Stadt, Raum Und Gesellschaft: Henri Lefebvre und die theorie der produktion des raumes. Munich: Franz Steiner, 2005.

Schrader, Ben. "Labour at Home: The first Labour government and the familial suburban ideal." In At Home in New Zealand: Houses, History, People, ed. Barbara Brookes. Wellington: Bridget Williams Books, 2000.

—. We Call it Home: A history of state housing in New Zealand. Auckland: Reed, 2005.

Seager, Samuel Hurst. “Architectural Art in New Zealand.” RIBA II/19 (1900): 490.

Shaw, Peter. A History of New Zealand Architecture. Auckland: Hodder Moa Beckett Publishers Ltd, 2003.

Shields, Rob. "Henri Lefebvre." In Key Thinkers of Space and Place, eds. Rob Kitchin and Phil Hubbard. London: SAGE, 2010.

Shirres, Michael P. “Tapu.” Journal of the Polynesian Society 91 (1982): 29-52.

Smith, Jean. "Memoir No. 40: Tapu Removal in Maori Religion: Parts One and Two." Journal of the Polynesian Society 84 (1975): 1-96.

Stacpoole, John. Colonial Architecture in New Zealand. Wellington: Reed, 1976.

Stanek, Lukasz. Henri Lefebvre on Space: Architecture, urban research, and the production of theory. Minneapolis: University of Minnesota Press, 2011.

Statistics New Zealand. "Cannons Creek East Community Profile.” Statistics New Zealand. May 30, 2003. http:// www2.stats.govt.nz/domino/external/web/commprofiles.nsf/printing/23A3150BEFF630C0CC256D2B00763B07 (accessed March 5, 2012).

—. "Cannons Creek North Community Profile." Statistics New Zealand. May 30, 2003. http://www2.stats.govt.nz/ domino/external/web/commprofiles.nsf/printing/2239AD6AA654F7BCCC256D2B00763973 (accessed March 5, 2012).

—. “Cannons Creek South Community Profile." Statistics New Zealand. May 30, 2003. http://www2.stats.govt.nz/ domino/external/web/commprofiles.nsf/printing/C5523E33C1950BDCCC256D2B00763A3D (accessed March 5, 2012).

Tafuri, Manfredo. Theories and History of Architecture. London; New York: Grenada, 1980.

Te Ahukaramu, Charles Royal. “Te Ao Marama - The natural world: The world of light and darkness.” March 10, 2009. URL: http://www.TeAra.govt.nz/en/te-ao-marama-the-natural-world/3 (accessed August 20, 2012).

Toomath, William. Built in New Zealand: The houses we live in. Auckland: Harper Collins, 1996.

Venn, Couze. "Michel Foucault." In The Wiley-Blackwell Companion to Major Social Theorists, eds. George Ritzer and Jeffrey Stepnisky. Malden: Wiley-Blackwell, 2011. 
Walker, Ranignui. Ka Whawhai Tonu Matou = Struggle Without End. Auckland: Penguin, 2004.

—. "Mana and Identity." Historic Places, (1990): 4-9.

Wilson, Gordon. "Full Report on Wilson House." Home and Building, (September 1953): 28.

Wilson, Gordon, and Reginald Hammond. "Low-cost Houses: Designers' explanations to cabinet." Building Progress, (1953): 8 . 